E Libit Jos. Danson

7.

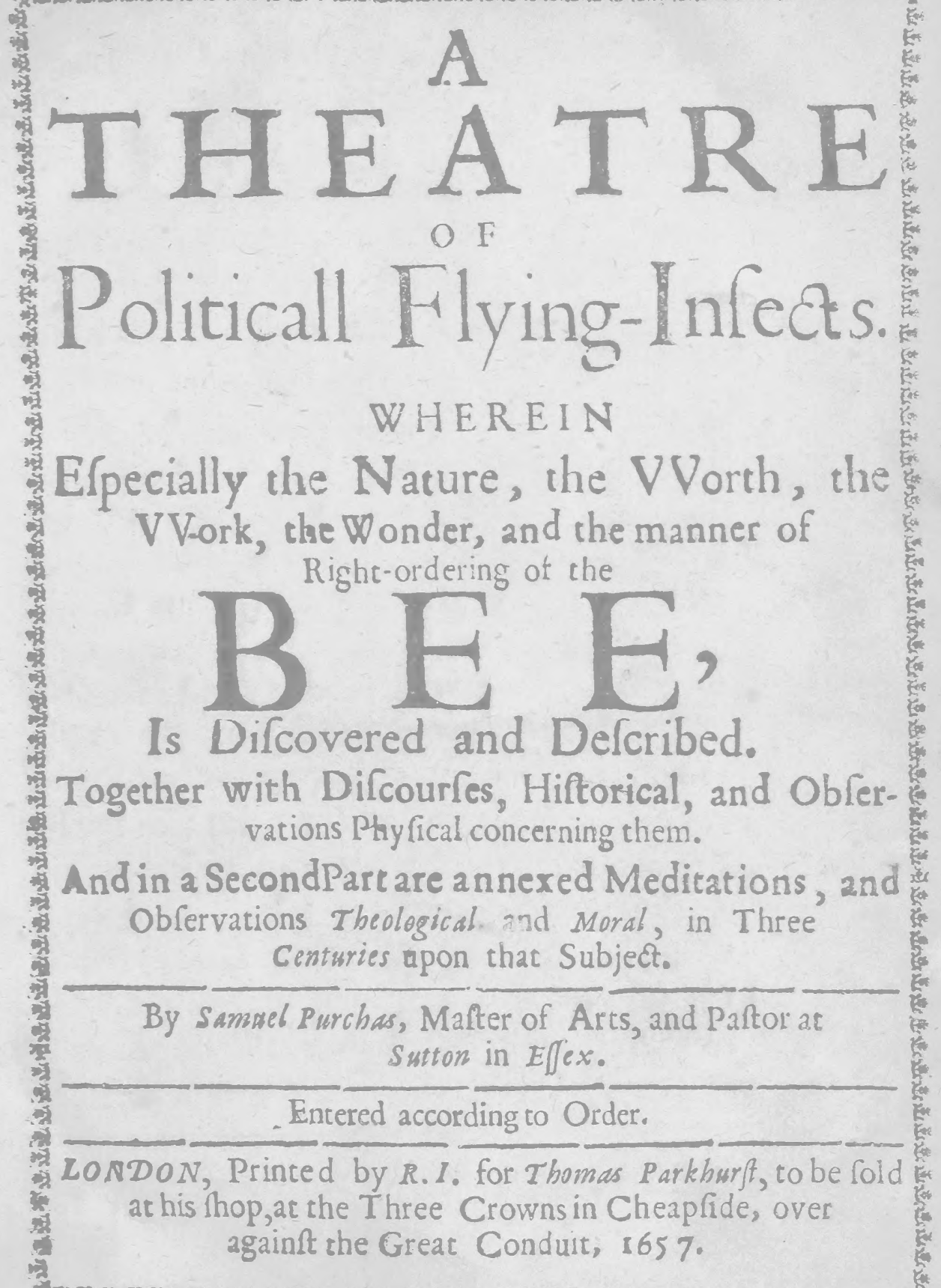

W 


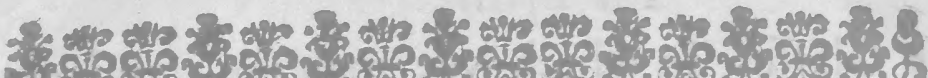

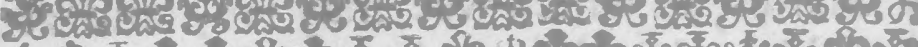

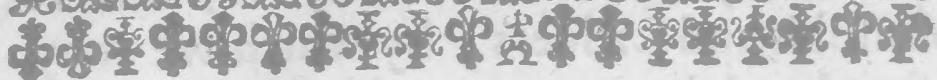

\section{TO THE}

\section{RIGHT HONORABLE,}

Truly Noble, and Religious

$$
\text { LOR D, }
$$

Robert Earle of Warwick, Baron of Leez, \&ce.

RIGAT HONOR $\triangle B L E$,

ARAEHE Creatures are the Book

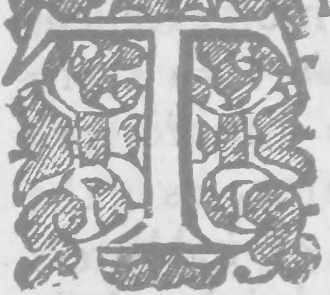

of Nature, as faid Anthony the Hermite, who being demanded by a Philofo- Socrat hir. pher, how he could polfi- Eccler. ly fpend his time in the 1.1, 443 .

Wildernels, feeing hee was deftitute of Books?anfwered, My Book, O Philofopher, is the nature of all things crea d by God, which when I pleafe, I can perule and read. The world is Gods Library, God manifefted and drawn out; and all the creatures a:c

$$
\text { A } 2
$$


25 GIsfres, in which wee maylee, and 25 Scaffolds and Ladders, by which we may afcend and draw nearer to him: For God is a light too ftrong for our fenle, therefore we muft ( with him in the ftory) look for the Sun in the Weft, not in the Eaft; behold the Lord as he is reflected, and refracted, firft in the glals of his Creatures, and his Works : And then fecondly, in the face of his deareft Son:

God in the School of Nature, ufeth 2 method fo fuitable and correfpondent to our dulnefs, that our meditations fhould not want in the Creatures Volumes (I may fay) wherein to read moft excellent admonitionis and inftructions : In every creature are they engraven in ordinary characters, and in leffer a print; as in the Scriptures, they be written in capital lotters once, the Creatures âre as a bright $\mathrm{gl}_{2} \mathrm{~F}_{\mathrm{s}}$, wherein we may behold our Ged; For as God is a glafs in heavea, wherein all his creatures are feen, fo are the creatures a. glafs upon earth, whercin we may behold

Sir John Hay. ward, Davids Ttarse and know cur God. They are Trumpets
of his honour, witneffes of his worth, bel- 


\section{Dedicatory.}

lows of out love, fpurs to our dulnefs, and judges of our unthankfulnefs.

There is fome good in all creatures, the meaneft hath a beam of (iods Mij.fy, yet fome have more than others, the Bees more than (almoft) any. That a little neglected Ofrald Crollii creature Thould bee fo cuicious in Archi-ca. tecture, and in the fabrick of her hexangle Combs fhould obferveas juft proportions as the beft Geometrician, we fhould fufpect for an untruth, if wee faw it not daily. practifed by them.

Nicofratus in Aelian, finding a curious: peece of work, and being wondred at by one, and asked what pleafure he could take. to ftand as be did ftill gazing on the Picture? 2nfwered, $\mathrm{Had}$ It thou mine eyes, my friend, thou wouldft not wonder, but rather bee ravihed as I am, at the inimitable art: of this rare and admirable pece. I am. fure no Picture can expreis fo much wonder and excellency as the Imalleft Infect: But wee want Nicoftratus his eyes to behold them.

And the praife of Gods Wifdome and Raymundurim. Power, lies alleep and dead in every crea Theolog, rastan A. 3 ture. 


\section{The Epifte}

ture, untill man actuate and enliven it, I cannot therefore altogether conceive it unworthy of the greateft mortals to contemplate the miracles of Nature, and that as they are more vifible in the fmalleft, and almoft contemptible creatures, for there moft lively doe they exprels the infinite Power and Wifdome of the great Creator, and erect and draw the mindes of the moft ineelligent to the firft and prime caufe of all things, teaching them as the power, fo the prefence of the Deity in the fmalleft In: fects.

What thould bee prefented to great men, but great and goodly gifts? In this perhaps many will comply with mee, but then readily deny, that 2 Difcourfe of Infects is to bee offered to your Honour; but I eafily trample on fuch exceptions, for although the creatures herein bandled, bee fo fmall that they cannot fully bee known, and (as worthlels, and ufelels) bee undervalued by many, yet by judicious wife men, who meafure things not by greatnels, but by goodnefs, they will not only be prized, but praifed;not only magnified, 


\section{Dedicatory?}

fied, but admired. In all parts of naturad Philofophy, the knowiedge whereof is moft difficule; the contemplation laborious, and the nature moft obfcure. I have (Faich Aldrovandus) found that moft diffi. Llsior. cult which is converfant about Infects, and that for their notable, and admirable fmalnels, which is the reafon (faith he) that no man as far as I know, hath delivered many memorable things of them: Only arrfrotle of the Grecians have difcovered fome things worthy to bee known; and Pliny of the Latines fomewhat more, which be collected from the Monumenis of Greek and Latine Writers (which are now loft) arid fome few things befides there are, which later Writers have taken notice of, but alt folameand imperfect, that ftill much re. mains to beadded and amended; and fo brief and obfcure, that many ftillare ignorant and deceived.

Scatiger is very angry with Cardane, that Scalig. de fub. ifter Ariftotle he fhould write of Bees, and add nothing neve, nor true: Whereas. learned Scaliger endeavouring to confute him, is guilty of many abfurdities , I can- 


\section{The Epiftle, oi:}

notbut expect to hear the fame reproach from fome, whom I only requeft judiciLipfii Prefact. oully to read, and then to cenfure.

Embroiderers, of threds of divers colours (in the new world of various feathers) make a coftly and delightful Hanging: So VVriters out of 2 thoufand parcels, an uniform, and agrecing body; whom I have laboured to imitate, where I have failed, pardon my weakneis, and accept my good will.

But my long Epifle is injurioas to yoút Honours more neceffary employments. The Lord preferve your Elonours perfon, with your Eonourable Confort, and all the Noble Branches defcended from yous.

\section{Your Honors humble and lowly Oracor,}

Sannial Purchas.

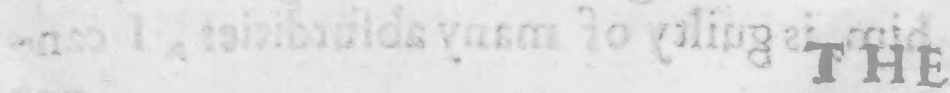




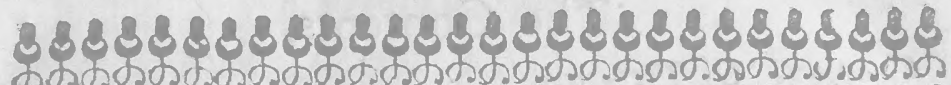
a

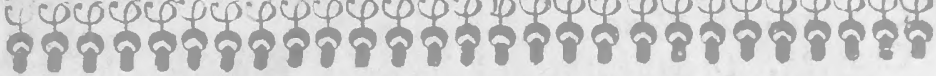

\section{THE
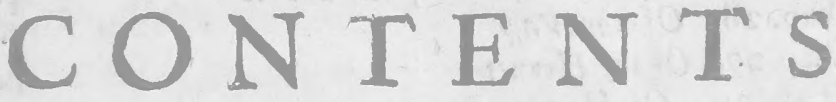 \\ O F THE \\ Several CHAPTERS.}

CHap.1. Of the Excellency of Bees

Page I. Chap.2. Of the Name

Chap.3. The Definition and Defcription

Chap. 4. Of the Kindes and Colowrs

p. 2

p. 3

p. 8

Chap.5. Bees nature and properties

P.II

Chap. 6. Bees Politicks, Eihictes, Grc.

P.I6

Chap.7. Of the Bees lenfes

P.22

Chap.8. Of the Queen-Bee

p.27

Chap.9. Of the Drone

Chap.10. Of the Generation of Bees

Chap. II. Of the Hives, and ordering them

Chap.I2. Of Seass for tibe Hives, and Bee-Garden

p.35

Chap. 13. Of the Bees-work.

Chap. 14. Of fworming, and biving of Bees

Chap. 15. What Flowers tbe Bees gatber of

P.42

p.57

p.6i

p.67

p.77

Chap. 16. Of tbe orcering of Bees

P. 92

p.96

Chap. 17. Of Bees breatbing

Chap.18. Of Beestemperarare: feep, and age

p.107

Chap.19. Of Bres F'igbting and Robbing

Chap.20. Of Bees Enemies and Sicknefies

p.108

P.III

P.II6

Chap.21. Of the Hony- dem

p.I23

Chap.22, of Hony

p.I35 


\section{The Contents.}

Chap.23. Of Tree-bory

Chap.34, of Waxe

Chap.25. Obfervations and difcourfes Hifforical and Fabulous

Chap.26. Objervations, Pbyfical, of c, P.I6I

Chap. 27. Of diverskindes of Wild. Bees p.169

Chap. 28. Of the wafp

Chap.29. Of the Hornet

Chap. 30. Of Humble-Bees

p. 179

p.18I

Chap.31. Of Grasbappers

Chap.32. Of American Bess

T.186 p. 188

P.193

p. 202 


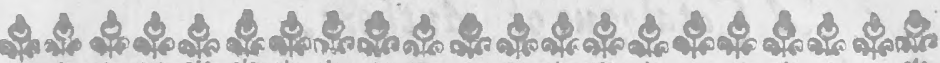

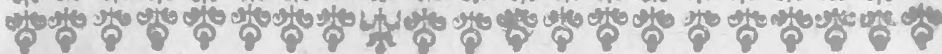

\section{A Catalogue of fuch Authors as are cited, and made ufe of in this Tractate.}

A

$\mathrm{M}$

R. R. Abbot

Abynzoar

J. Acolt 2

AAtuarius

Elian

Elope

Mr. Adams

Agacharfis

Raimund de Agiles

Cor.Agrippa

Albertus

A. Alcyne

Uliffes Aldrovandus

F. Alvarez

Alex. ab Alexand.

Ambrofe

Andernacus

Amyretus

Jo. Anglicus

Appian

Alex.Aphrodiff.

Hier.Fab. ab Aqua-

pendente

Aquinas

Ariftophanes

Ariltoteles

Athanafjus

Atheneus

Auguftinus

Avicenna

Anufonius
B

Dr. Balcanqual

Hermolaus Barbarus

Baronius

Barrudas

Broughton

Ba alil

A. Batele

Beuhinus

Gorop.Becanus

Beda

A. Bellunenfis

Pet. Bellonius

Bernardus

Pfeudo. Berofus

Bodinus

Bonfinius

Mr. Bolion

Gio. Botero

Mr.Brathwaye

Geor.Brawa

Mr.Butler

Buxtorfius

Cajus

Aioyf. Cadomuftus

Cxi.Calcagninus

Calepine

Calvinus

a 2

Camden 
Camden

Camerarius

A!. Campenfe

T.Cancipraranus

Julius Capitolinus

Cardanus

Georg. Cedrenus

Cor.Celfus

Ranulph Ceftrentis

Chaucer

Chrifoltomus

Chyrrzus

Cicero

Pedade Ciecs

Claudian

Dr. Cleland

Mr. Cobbs

Columella

Nacal.Comes

Val.Cordus

Fernand. Correfe

Mr.J.Botton

P.Botion

Mr. Cowper Bithop

Elias $C_{\text {screnfis }}$

Pet. Crefcentienfis

Pet. Crinitus

Crollius

AElius Ju!.Crotea

Cxl. Augult.Curio

Q Currius

Culpinianus

Cyprian

D.

Dalechampius

Dr. Day

Diodozus

D. Dike
Dion

Diolcordes

Mir.Down

E

Tacob Ekcelius

Mr.Elton

Marcel.Empyricus

Epiphanius

Erocis

Eltates of the world

Euripides

Eultarhius

Eurropius

E

Fazelius

Dr. Featly

Fernelius

Fran.Fernandus

Marfil Ficinus

G.Fletcher

Florentinus

Mr. Fosbroke.

Franzius

Otho.Frifrngenfis

Fuchfus

Mr.Fulier

J. Fungerus

G

Galenus

Mr.Garey

Mr.Gataker

Theod. Gana

Cor.Gemma

Genuinianus

Gilpine

Hier, Girova 


\section{¿ Catalogue of Authors:}

Rob.Gloceftrenfis

Godignus

Godwin

Mr.T.Goodwin

Ber. Gomefus Miedis

Mr.Googe

Gregorius magn.

Gregorius Nazian.

Mr.R.Greenham

Hil.Greg. Syrald.

J.Ja.Gryneus

Gualther

Añ. Guevara

Guild

H

Hacklait

D. Hakewill

D. Hall

Mr.Harris

Mr.Hartlib

Di.tuarvey

H. Hawkes

J de la Haye

Sir Jo.Hayward

Helmont

Mr.Herbere

Herodian

Herodocus

Anrode Herrera

Hefychius

Heffod

Hieronimus

Higinius

Hilarius

Mr.Hill

Pet.Hifpanus

Hippocraies
Mr.Hoard

Mr.Holbroke

Hollerius

Dr.Holland.

Homer

Horatius

Job Hortop

Hugo Cardinal.

\section{I}

M.joT.Jacombe

Dr.James

Jarricius

Dr. Jenifor

Jofephus Indicus

C. Jobfon

Dr. Jones

Mr.Johnftone.

Jolephus

Jovius

liocrares,

Ifidorus $\begin{aligned} & \text { Hifpaleni. } \\ & \text { Pelufroto. }\end{aligned}$

Silius Italicus

JuAtine

Juvenal

K

Dr. Kilbie

Kinchie

Dr.H.King:

Dr.J.King

Krantzius

I.

Lactantius

Dr. Lake

Jo.Langius

Mr.Lawion 


\title{
$A$ Catalogue of Sutbors.
}

Levin.Lemnius

Ambr Leo

Jo.Leo

Nicol,Leonicus

Lerius

Mr. Levic

And.Libanius

Linfchocen

Lipfius

T.Livie

Masth.de Lobed

Mr.Lockyer

Lucian

Iusrerius

\section{M}

Mocrobius

Magirus

J.Magrus

Olaus Magr.u8

Majolus

Bapt.Mantuan. Martial 3 Epifcop.

Matth, Martunius

Marullus

Machiolus

Pet.Marthew

Mr. May

Menola

Her. Mercurialis

Mro.Meridech

Mefue

Ped.de Mexia

Mr.Mliles

Jo.Milecius

Mizaldus

Rhodol Mzdius

Morylon

Moweffetus

Nicander

Nicephotus

Nicetas

Nigidius

Niphus

Joach.Nizxus

\author{
O \\ Julius Obfequens \\ Oneficricus \\ Paulus Orofius \\ Adamant. Origines \\ Ortei.us \\ Olorius \\ Ovidius \\ Or.edo
}

$\underset{\text { Dr.Page,Sanct.Pag- }}{P}$

ninus

Palladius

Guid.Pannyrollus

Paracelíus

Paulanias

Pennius

Perottas

F. Picolomineus

Phavorinus

Philo

J.Picus, E.of Mirañ.

Pigafett2

Pineda

Gı or.Pifcato rius

Guil. Plantus

Dr.Play fere

Plaueus

Pliny

: Plutarch 


\section{' Catalogue of Autbors.}

Polacus

Polybius

Porcaccbi

Dr.Prefton

Dr.Prideaus

Dr.Primeofe

M.Purcbas

R

Mr. Randal

Raymundus

Mr. Remnant

Mr.Reyner

Mr.Reynolds

Ramufio

Beac.Rhenanus

Ribera

March.Ricius

Riverus

Cx!.Rhodiginus

Mr.Robers

Mr.Rollenlon

Hier.Romano

Rofinus

Mr.Rowiandfon

Hieron, Rubeus

$S$

M.A.Coc, Sabellicus

Salmeron

Hea.Salmowth

Salvian

Sands

Mr.Sanderfon

P. Sanflorus

Joand dos Santos

Jo. Sarisberienfis

J.Cx f. Caliger

Dr.Sclater

T. Scos
Scribonius Largus

Selden

Seneca

Servius

Dr.Sibs

J.Silvelter

Huldrichus Smidel

Socrates

Solinus

Sophocles

MroSouchern

Spanhemus

Spencer

J.Stobrus

Mr.Stock

Dr.Stoughton

Strabo

Valfridus Serabus

Mr.Serwether

Stuckius

Mr.J.Stanes

F.Stancarus

Sylvacicus

F. Suarez

Suidas

Mr.Swife

Mr.Sym

\section{$T$}

C. Tacitus

Tarnovius

Dr.Jer. $\}$ Tayler

Tertullian

J.Ra.Textor

Theocri:us

Theodoree

Theophilaet

Theophraftus

Ped.Teireira. 
1 Casalogue of Autbors.

A.Theret

Mich,Toxires

Maximul. Tranilisa-

nus

A. Turnebus

Geor. Turonenfis

Willer. Tyrenfis

Arch.

Tze:zes

V

Valerius Maximus

F. Valefius

Valleriols

Varro

Gasri lafio de la

Vega

L.Veiulam

Vigetius

Vinceatius
Virgil

Polyd. Virgi

Virichindus

Fulvius Urfinus

Dr.uher

Dr. Wall

Dr.S. W Thard

M. Warion

Weckerus

Di.Williams

Jod Willichius

Xinophor

2archy 


\section{TO THE}

\section{Author upon his Phyfio-theological Hiftory of BEES:}

TXTence this brave flame? and to what facred fire

(D:vine Prometbens!) do thy thoughes alpire?

Mytterious Nature takes it ill, to be

Dethron'd from her retired Majelty :

Thy darirg hand hath taken off her drefs,

And the w'd her naked, mid'st her hid recels:

Thou haft broke up her Archives, and haft fes

To fale, tier Jewel, aod her Cabinet:

Her liad in her Nur; and now thy Bee

Is not her work, but her Anatomy,

Which thou balt handled too, at fuch a rate,

That 'wwere but one ftep higher to create ;

Thou haft her Miracle fo here made known

'Twas ner'e hers once, more, then 'is now thine own;

Hers at the beft was natural, bue thine

Is through thy learned labour made divine;

Paradife is her Howry Garden, whence

Shee fuck Elixır all, and Quinteffence,

This facred fympathy wee nei'e did know

Till thy high foaring fearch had found it fo:

That which wee all have yet admir'd was but

The Ahell, thou only feaftedlt on the Nur;

Whilt rowring far above our common fenfe

Thou rakef heaven by chy violence;

And with thy foul an wing, invad't the skyy

Bringing us Anuels Manna from or high

In pious raptures; thus this work of thine

Gives us another table Smaragdine:

5




\section{ELEGIES.}

Abore and Here are like the Gordian Iwrift

Is thus untavei'd by our Tulmegili:

Now Hearen and Earth in one comb. 'd we lee?

And God and Nature cencis'd in a $B E E$;

This wee mut owe to thee, shy lea:n diweat

Bankiuois, and leaves us dying in thy aeb::

Pardur mee then il unso thee 1 do

Affer: the keyes of Earshard Heaven too:

Gather cur Bees! and tiv'd trom Envies harm,

Thrivo way sthole frocks from whence thele Graces fwarn.

\section{N. T.}

\section{Upon the Authors Eliborate Treatife of BEES.}

R Rokers in verle condemn ir as a crime

DTo preface $T$ flue with a ragged time.

Oh ti is doch !trike mee dumb! ard bids mee looks

Idraw no Cur:ain to ecliple thy Book :

No, if my Lachisy-mufe fets ou:, poor thee

Runs but :o ase up eyes to gaze on thee :

Le: o her s fourdity worth in fiver meerle

Whilf to thy Bees I rang a jarrirg Kettle.

My Mufe had kep: at home, but that the fees

Even Diones themielves indulg'd a mong ft thy Bees:

l've fumeires view'd thy fmall Volaticks flye,

Like goiden a:om's hov". ing in the sky;

And the ceriserding genty ore by one,

Like curied acts dithev'ld from the Sun, 


\section{EZEGIES.}

This objeft pleas'd mee well, but when I fpy

By wings of fancy poys'd with gravity:

Thy thoughts to foar a higher pirch, why then

My mind's unpleas'd, but better pleas'd again:

l're peep'd into thy Hive, sby Book, and I

Finde Bees t'have lefs of art and induftry ;

And fweeners too, and fo muft needs confers

Ilong to tafte thy hony from the prefs.

Each page a comb, each word's a bell from whence

Mellifluous dew's diftill in eloquence.

Were I tolead thy troops, hither I'de flye

Onevery leaf to prove their Chymiltry.

Here tyr $\mathrm{r}^{\mathrm{d}} \mathrm{d}$ and weary thoughts may fweetnels feas,

And re-aflume new life with fonatban.

Thy obfervation's quick, what thou hatt writ

Speaks thee Dame Narures chiefelt favourite.

The thoughis of various Authors thou haft fhewa'?

And prov'd them Aye-blown fancies of their own:

Thou knoweft each Bee, their flight, and tracts cheir Atage,

And fo haft wrote a fecond $P_{1}$ lgrimage.

One hony"d ore a Tyrants eye to feaft

Did run the Gantlope through a Hornets neaft.

Wafp-like, who at thy Book exceptions take Makes thee a Martyr for thy fweerne? fake.

Fo. Angier. 


$$
\text { ELECIES. }
$$

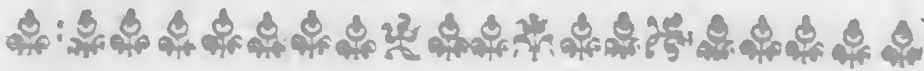

Advenerabilem Apiarium Authorem, Mr. Sam. Purchas Miniftrum, de Poly-hiftorico fuo Mellificio; nec non lectorem candidum, carmen Anagrammaticum.

$$
\begin{aligned}
& \text { Sammel Percas } \\
& \text { Mel, curas apes }
\end{aligned} \text { Nomen }
$$

N Elcuras apes, mago cues bas diligis illos

N1 Neefwow, ant nlio regligis ip, e nodo.

Sar.Eta Theologie pandir my fortia ude

Sic tha con cribit wada $P$ biloo log se

Roevoren of biftoricum libronumc alpice dobto

Esce Minsfitr ovmm, aique esce Magifter apum.

Ja. Norricius:

\section{To the Reader upon the Philo-logical and Theo-fophical Treatife of B EES.}

TIV Hat Arifolle, Pliny, wrote before, Tirgil, Alurczana, Scaliger, Butler more;

In this one book fie thou maseft more than any,

And marvell not if that I do fay many.

All that have written of thefe Irleas sacuse

So much, which very liftec are in fature. 1 do ros krow whether for aure owa part 


$$
\text { ELEGIES. }
$$

Bees nature molt, t'admire, or Mafters art;

Who centuries hath perus'd, his eloquence

Befides experience, mark t'nittory,

Philolophy, ith' Treatife, Theol'gy,

You may call't an Encuclopedy, all

For tongues,arts, matter,pos'cive polem 'cal;

A Bee-hive for thy life, mott full of hony

Purchale then this Purcafan work, thy mony:

- Twill far excell, exceed to thee as gainfull,

As 'twas though pleafant, to the Writer painfull:

For a lubject fo good you cann"s lefs give,

Give then good words, and praife is while you live:

Or elfe amend, choofing, or to do betrer,

Or to defilt from the cenforious letter:

There's hony in his name, more in his book,

Which is mellifluous, come rafte as look;

Make chis Anthology Pantol'gy thire

Ambrofian Purebas Nectar Divine.

I wonder not it is fo natural

For thee to be' bout Bees biftorical.

Ant ¿े

C:itical, the

letter of cont

demnation,

Becmano

Seetke La. : sine A nagram.

This Treatife framed with fuch artifice

Shews fome paternal metemfychofis :

Though fome Ancilogifts fhall vilifie

The Work, Work man, both have my Eulogy.

\section{To Zoilus.}

Can Mimas do the like, will Momus like

This Polacthean Pantologick book ?

With tongue or pen do no: perftringe or Prike,

l'ie not be Mome, nor Mime, to be I look

While Bees (hall be, and thall their Hony give

This Bee-malters name, fame, when dead Anall live.

\section{Fa. Norrice Paftor of Carondun.}




\section{EIEGIES.}

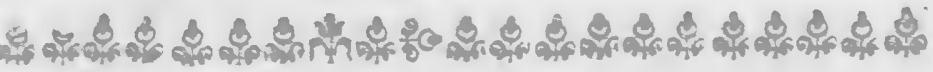

Upon the Authors Learned and Elaborate Treasife of BEES in both parts of it,

an Encomiaftick.

E Eder, read here a book of BEES diffeled,

R Their na:ure, ltaiure, feature, paris decected;

Tneir feedirg. breedirg, building, induftry.

Their prudence, providerce, fagacity,

Their peace, their war, their love, their morcal hase

Their Prince their Leadere, order in their Atare;

All there and more unfolded in fuch wife,

Thas it a Hive of giars, thou mayelt furmile.

Thes magnifie this little Creatures Maker, Tha: (1:) of fuch endowments made partaker; Wherein his Wiidome, and his power Divine (As in the heavens above) do clearly thine Io us: hand-writing; what thou there doft fee, In imalkr lezsers here imprnned Bee.

Nex: pralesthe Authors Bee-like diligence,

His reading, learning Bongexperience.

On the iecond And then read on to that wh ch follows next, Pare.

Eeclerafur 2. Dectr ne diffillirg ilke the Hony-dew,

sa

Meilifucus, moft plealan: upright, true,

O gaiker :hen the Hony from thefeleaves,

Thole vices Aye to which thy nature eleaves. And learn thole rertues which the Bees do each Thine under fanding, elfe this bout doris reach.

By bin lowing F riend ard Neigbtows, I. P, Mafter of Ants, P.F. 


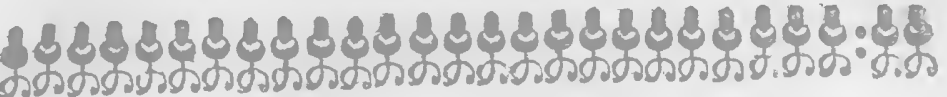

\section{Ad doctum Authorem, in Mellifluam} ipfius de Apibus hiftoriam carmen,

$$
\text { Eyususas wiv. }
$$

CZtribus eximiis mel Apesproducere luftrant

Sic (Purchas) librúr rofoida mella legis.

Que veteres fcrip fere diu, tw teftibus aquic

Arte probus; Landem dulce loquatur opues

Traltatus doctus,permi/cens utile dulci;

Sillans delicias Religione liber.

Hic labor, boc opus eft, Apibus medicina falmbr is

Condirur, ac medicam porrigis arse neanum.

My fica matkre marras, amor urget babendi

1 Nectar Apis? placida difcutis biftoria.

Gratulor ingenism, bibrume dum mente revolvo 2

Mel Japio fariptis asm pietase novum,

Guil.Rogers $A_{!} M K_{*}$

\section{Upon the Authors Treatife of BEES:}

T. Hat Creature ift' that God hath made?

But emblems forth fome fignal frade

Of that divine and higheft power,

Who makes unmakes, all in an hours

The fea is fll'd with fmull a d great,

The earth as full, and moft compleat,

The glorious heaven beyond compare,

That place where Saints and Angels are:

The bafelt worm, who ears but duft,

Speaks glorious praile, and that moff juft; 


\section{$E Z E G I E S$.}

Unito that God who made us all

In his own way; myfterial.

The eye of man is over dim

To fee the glory that's in him :

His hinder pares wee may behold

Which hee in Nature doth unfold.

Here is the Bee, a crearure fmall

Which Sans, the reft, may teach us all

I His pains, who hath this Bee expreft,

Shews whether Bee or Drose be beft;

Who reads this work thall therein finde

A skilful pen, an honeft minde.

Perufe it well, and thou fhale fee

More Hony here than in the Bee.

70. Loane Minitter of Little Scambridge.

\section{In Meliffologiam a viro omnifariam docto Domino Purchafo Elogium.}

Durrima mandantur cbertis do Apibss Moximerue,

1 Parvi momentip plaroque fialuzs

1 : Paratition vanis /ust jeripeare fertas Hilwa ni vuli falli redulus o fatuus

Falsmm pro vero iorpenti Comate prisfus

Devorat, (bine lopbia maximus ille labar

Neglegutar) (at os elle put ans in verba Magiffri

Jurare, indubium quiequid id ipjus cis

Amplecenens: Genio arridet falacia dulcis

Quoique feen pigrem (emper crit placidemo.

- Sedt.set in putei vener anda frientia fuedo

Antare of debes continue rigidus. 


\section{ELEGIES.}

10. A fudel oplatam tandeos comprendere $A$ lepium

I De nucem frangat qui volet su nucleuin.

Hoc iter ad verum, quo tu mi Purcbaje do tze

Tendebas, credens wobilius fapere:

Ex rebus quam libris, mox commercia agebas

$P$ arvis cum Infectis in quibus ipfe Deus

Emicat illuftris quorum Idiama ter.ebas.

(Gui Polyglo(fus eras) ingenio facili.

Vwminis bac libi pardebont Magnalia fumras:

Alque lequebantur. fribile quicquid.erat

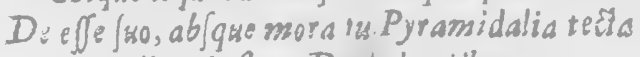

Ingrediens luftras Doedalea itla opera

De coits, Genefi, partu, pafiugue fi upendo

Horum quid regimen, qua Politcis manes

Illis contemplar is, que ad civilia bella

Spectant, ad pocen quomodo fint reduces, Anbrofium fuccum quis fit modus eliciendi

Stirpions varise arte lua Chymica. In uper bis de parvis mille Arcana recludis

Mr lificis, peritus que latuere alios.

2uocirca tibi qui debeiur bonore rependet

2 uicunque ingenus, proferes of merito

$C$ unctis hac in re palmam preripuiffe.

Plus of Apes viles infiruiffe fusm

Impigrum Dosainsm de Div, morum probitate

Oeconomi cura, regís \& officio

Qus lpect ant fopulum quam immenfa volumina quorum

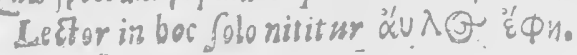

G. T. 


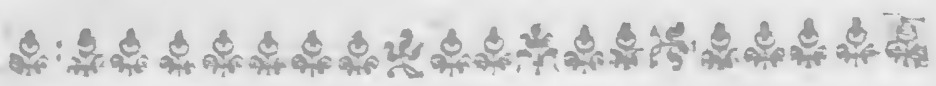

\section{To the Iearned Author of this Bee-like Liborious Trearite.}

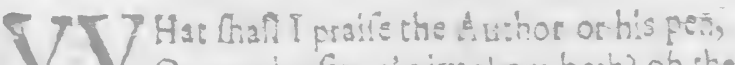

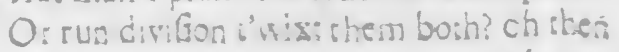
M. Muie rood dire, tis rame reeds ro: my layes -

Hij fathers P.igrmage earlt ware the bayeseg

I then wi l lieg ine foule of Moerctry

Intemale iex who entlous induty;

Jult ru'e, iveer concord and frusality;

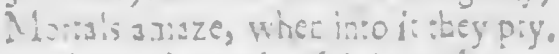

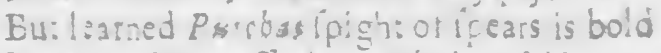

Tbeir Caftis :o aflauli, ard doth unfuid

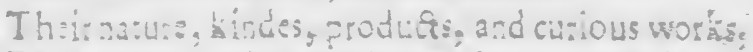

Their ralouig orde, weaith, and whatere iuths

Within the concaves of their go'des wail

He hasth ipsed ous, and doih impars io ait

Nuch worstis in leaft of throgs I now bsjecve

The butie bee hath aught me from her Hive.

Such Nalures A:t's booke cpe. come all and view,

Mytherivus arts, fecress both oid and rew.

Eus herear doth excell his prcyed skill

Surputing tir the rudecelis of my outil.

Gazve nedrasicas both Nlora! and Divize,

We tarh exracted from da:k Na:uies mire;

Mich habour tath fsezured chis piecious oar,

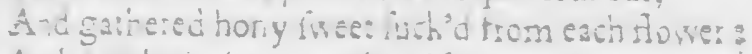

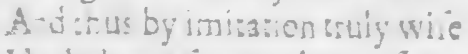

He duth no: coom to tearn of puiy fyes,

Thask stes the Adthor.admire the linile Ese,

Bu: g ve the God ef Widcome rraifes free,

Mule now be filen, lei rimielf rela:e

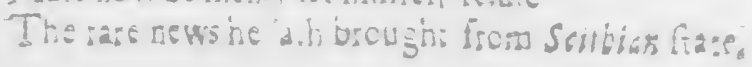




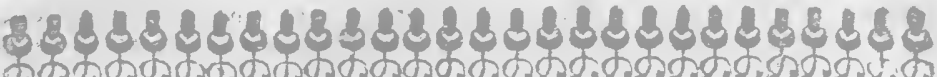

$E R R A T A$

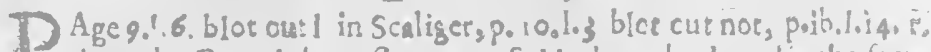
about the Cape debrun Speranz', ro black, yet both under the fame Tr ipique, why the Aby flio es are but Tawny Moores, when as, \&rco $q$, ib. 1.16 r.are very black,p. I 2 1. 8 r.quieicent, p.1 g.l.22. r. Aldrouandus, P. 30 l.34. 5 .out of, $P$ 30.in marg. ro Pod.de Mexia, P. 35.1.17 r.wanters, $p_{0}$

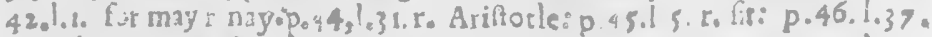

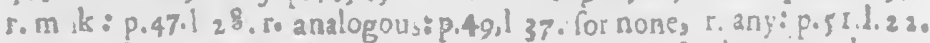

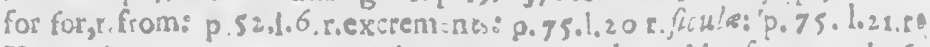
Hymetti; $p 75$ in ma:g.r. Maioporm 8 ; p.97ol.5.t. Moule; p 99.1.16. blot ous then; p.I0I l.19.5 put a; ib,1.24.5.upon the empty hive; p.104.

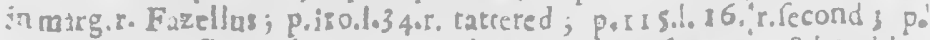
I19. in marg.r.Jozon dos, 2e. p.122.1.4.'or after, r. often; p.,123.1.10. blec

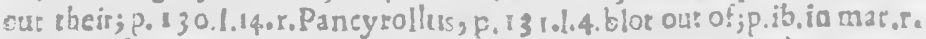
Pancyrollus;p.13 301.20 blot out dew;p. I 38.1.32.blot out alcribes;p. 144 -

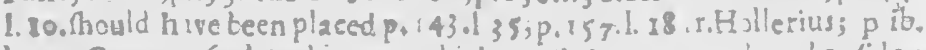
135 . G za,p 160.1.38.biot our which; p.b 1. 35 r. on tae wither fide :

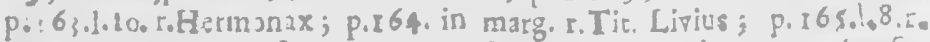
Olynthia; f.I 73 1.7. for one ounce of; r. Our of; p. I 79.1 .29 .1 tranlresle:

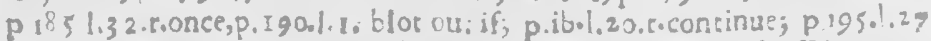

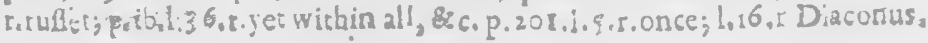

\section{ERRATA in the Secosd part.}

Page 259. in marg.r.D. Dike; p. 262.1.21.0, return; po 267.1.2I; ro makech them confifent; p. 3 I0.1.14.r.ftubborn; p.3 Ir.l.5 r.make; $p_{0}$ 328.1,ult. r.fpat; p.3.25 1 20.r.wrought; p.348.1 32,r.reine; 1.33. r.Bee; P.364.1. . g. for tangle, $r$ raile; p. 370 . Saft l ine, for Drones $r$ Daves.p. 374 . 1.6 r Plaucus;1.24 r.in Pitchers; 1.26.r.advantage; p.376.1 17.r. admit:

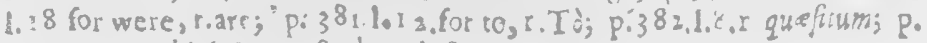
386.1.37.r.which is; $p 387.1$ 9.r.laft. 


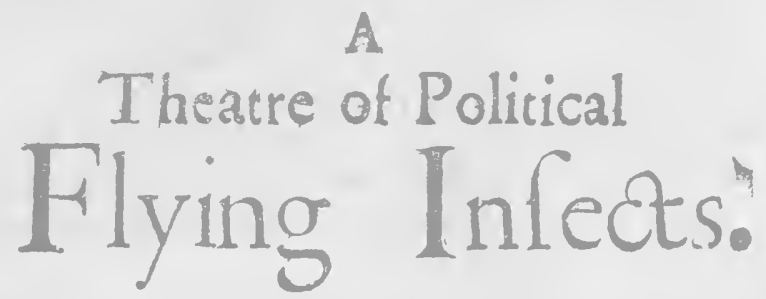

\section{HAP. I.}

\section{The Excellency of Bees.}

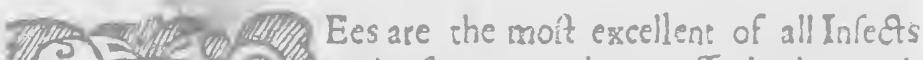

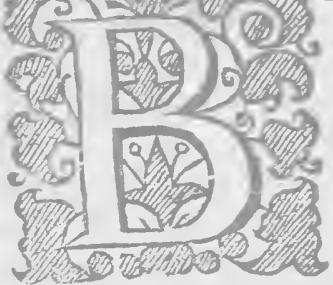
whatfoever, and exprefle both worth and wonder in all their waies: They only afford delightful food, and pleafant nourithmen for man, whereas the beft in ocher kindes ferve only for Phyfick, or the plealure of the eye, or the delight of the ear, or the cloaching of the body: the molt part whereof is by thele alfo fome way or orher aburdantly fupplyed; to that natures power is no leffe in Rees, than in the greateft, and molt perfect creacures; sur hee that made the Camel,and the Elephant, made the Bee too. This is fomewhat, but yer not enough; becaufe they 10. Rsin? Text. Epithe?. Dr. Jones are the molt excellent Creatures for Prudence, an 1 profit, ex-Eopitt, ad Pbi= cept mang and indeed the divine wildome hath thus ordered lere: $i r$, that wee mighe underftand that Prudence confifts not in the greatneffe of the body, but in the minde, which hach no need of magnitude, but as it is leffe, is fo much the more excellent. Carden. 1.7. de Variere? rerim, Here is majnum in parvo, a litile in quanity, but much in worth and qualiry.

The Bee is a little creatare, but Gods fmallef fprings prove atlength main Oceans, his leat beginnings grow into greac works, great wonders.

Who canimagine that fo many pleights and joints, cono B 


\section{A Thealre of Political Flyims Insects.}

nexioss, and concatenations, Dhould bee orderly difpoled in lo fmall a fabrick? Thar in a budy fo lietle, the joines thould move fo actively, the wiogs ftirre fo nimbly, the fting penetrate fo deeply, ebe fenfes utter forth themfelves fo tharply, Chryfor. Nay, the lungs, (though fearcely vifible) to breach fo powerComment in fully, dothany then glory, or is proud for his skill in various Epitt. Pauli ad arts! What in this refpea is wifer, or better infructed thanche Pbilip. c, 2. Bee? What Artificer is fo various, what Painter, what Geo4. merrician can imitate her works ?

Why do wee then marvail at the Tower-bearing houlders of Elephants, and not racher where Nature hath planted fo many fenles, and fuch induftry in fuch litule bodies? where is bearPliny sizh, no feeing, fmelling, tafting, and feeling, yea where are the
ereature live or mave without them. Mall wee fay of the parts of the fame? and yet in this lietle Bee is fuch fagaciry and induftry, as the like is nor feen in creatures of greater quantity.

The great Artifex of Nature hath enlarged the fmaller creaTerrul. adves tures with wifdome, and invention, fo teaching that greatneffe fus Marcion, is to beefound in meanneffe (as the A poltle faith) ftrength in lib. 1. infirmities. Imitate if thou cant the Bees buildings, the Anes tills, or lodgings, the Spiders nets, the Silk-worms webbs. Such therefore are not a little miflaken, who affirm that these is neither much Arength, nor yet fuch beauty in Imall creaAxl. of Gue cures, as in the greater; nay, that whereas the greater, as the Evara famil. E. lephant, and Horfe are profitable, the leffer ferve oniy to offend, piी. whereas what Creature for profit can compare wo the Bee, or the Sills-worm?

And though the greateft thing the Vulgar praife her for, is ber laborious induftry, yer indeed she leaft thing thas may bee prailed in her, is her indufry.

For, If old times admire Calicrate:

Div, Barres sifro day.
For Ivory Emmets, and Mermecides

For framing of a rigged Sbip So fmall,

Ibat witb ber wings a Bee can bide it $\triangle B_{\text {. }}$

Admire weetsen itb a wife omnipotence,

Wbicb dosb asibin fo narrow fpace dipence So fitfo a fing, fo fout and o aliant bearts. 
$A$ Theatre of Political Flying Inferts.

So loud a voice fo predent wit, and art:

Tbeir well rulid fiate, my foul fo mucb admires

$\tau$ bat durft I lofe tbe reigirs of $m y$ defires,

$I$ gladly could digreffe from defigm,

To fong a while tbeir facred difcipline.

\section{CHAP. II \\ Of the Name.}

IN Hebrew \& Bee is called, דִ דִבְבר Debora, from the order of

their work, which they frane with admirable art and induftry; Among the Grecks, Beeshad various names, according to the rariety of Nations, and Couneries, but the moft Vulgar was,

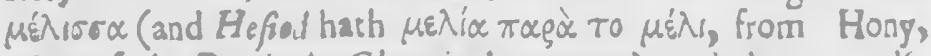
whereof the Bee is the Chymical preparer) and they are allo called, $\mu \varepsilon \lambda_{1} \tau T \alpha 1 \propto \mu \varepsilon \lambda \varepsilon T \hat{\omega}$, becaule no Infeet is fo profitably iuduftrious. The Latins call them Apis and Apes, becaule as $V$ irgil, they are trunca pedum primo, firft bred without fees: And indeed the Worm or Potential Bee, called by the Greeks $q \alpha$ dop, S:badon is withotit leggs, but affer her Metamorpbolis (of which afterwards) fhee comes forth a fix-legged crearure, but becaufe this Etymology anfwers not Analogy, as other compounds, it is fuppofed by others to bee a fimple word: So alfo Servius and Pyro Peroltim in Cornucop. Lucian therefore calls them, $z \tilde{\omega} \alpha \ddot{\alpha}^{\prime} \pi 0 d \alpha, A$. Canlep in dietsiorar.

The word Bee, according to Goropino, is originally Duech, and therefore Englith; and fo compofed (faith hee) becaure it affords us many things: W2x, for curing of dolours, wounds, ulcers; for lights, Ceare-cloath, and many ocher things; and for Hony it would require 2 dajes work to declare the benefit and worth thereof. And though thefe bee great benefies, yee there are more excellent and remarkable to bee oblerved from this Creacure : For every Conamon-wealth, every Kingdome receive their beft directions and precepts, whereby the duties of the King rowards the people, and of the people towasds the King, and of the Citizens among sterofelves are 
mol ciearly taught. If they hold forth any pasterns to us, wee readily write after them, and practife them. For it fig piffes alfo, faith bee, to command or rule, becaufe it is the fame lupream Majefty, that affords and beftows all things, and commands all things. Wherefore the Arcinitect of words by 2 6ingular prudence hach commended to us Monarchy, inculded in certain limits by the name of Bee; which fate whofocver attains, it is neceffary that hee imirate the King of Bees, who to deports and carries himfelf, that hee is beloved, rroriced for, and procected by all the Bees; and yet in the mean time fo farte frox offering injury or wrong to any, thai he hath zofting io turt any ( 10 Goropius ) but which is truer and betse:, be never afech it to the hurt of any.

\section{CHAP. III。}

\section{Fis Definition and Defrription of a Bee.}

A Bee is a Flying Infeet, four winged, fix legged, bef?'A skilled in making of Hony, her thape is little, brown, bowMouffer The ing, oblong, nor globous, as fome: Her eyes are covered with arr. infector. a horny membrane, or tunicle for their better defence and Arit. de par fafecuard; they are of a hining black, like Jer, tranfparent as sibus, a nimal. Glafie, immoveable, contrary to A frifarle, who faith, all ino. i,b. 2. e. 13 . feets move their eyes, as four-footed beatts their ears; not and alfo plin. funk within their heads ( as Minfer us ) but fomewhat promi15. 33. C. 3\% nent, no eye-brows: Their eyes are placed on the outride of their cheeks, or iather are in ftead of cheeks; oblosg, greater above than below, through which she foecies of things vifible are conveyed to the commonfenfe. The horns are cato led by Arifotle, Antenna, becaufe they hold tl emforth before them: They are very pliable, and readily bending almofs. every way: th $y$ grow almolt at the top of eithes ese, fur defence with iwo joynts, one ciofe to the head, the other towards the misdle, fo thar thee can put them forth at full length, when thee will, and draw them down aga in clofe to her head: And they are the proper infruments $r$ f the fenfe of feeling, by which, wish the leaft toucb, fhee fuddenly fenteth any tangible obje $a_{\text {, }}$ 


\section{A Theatre of Political Flying Inj:}

The Drones eyes are farre larger, being almolt swo thitds of sheirhead, with swo moveable wreathed horns, growing out together between the eyes, but exiending likea fork.

For gathering her provifion, thee hath swo inltruments, her fangs, and her congue; her fangs in fafhion of a pair of pincers, hang not as the jaws of other things, one over another, butfide-waies, one againht the other: Her tongue is of that length, that her mouth cannothold it, but being doubled between her fangs under her throat, it reacheth to her breaft; it is divided ineo tbree parts, whereof the two outmoft ferve as a cafe to cever the third, which being the chief, the Bee in ber work, furtech forth beyond the o:her, and draweit in again as thee pleaferh, and thischird is likewife parted ino three; fo that there are five in all.

In their fangs or chaps, wherein are their teeth, stiei: principal Arengeth conflfterh; for in their confliss, where they llay one with their fting, they kill ewenty with their :eeth, quickly biting off the wings, or breaking the leggs of their adverlaries: And therefore Mr. Butler was lomewhat deceived, who accounteth this pinching of other Inferts (for againft them only do they ufe them) to bee rather a chiding, than a fighting, a warning, than a punifhment; being indeed a deadly and mortal infrument of revenge; To that after a battel you fhall fee them lye fprauling, hopping away, and crauling in great multitudes, eirher drawing on the ground one, or more of their leggs, of doubling the nether part towards the ground; or curning the fame awry to the one fide, or other, bus as many as are bitten, within a horr Space will ceriainly dye.

They runne at firt limping away, but (urvive very little And that they are net ftung to death, that in fuch variety of ma tions, prociaim their various hurts is yery apparent.

Firf, Becaufe there is no fting appearing in them; nay, moie die lamed in their legg3, than hurt in all oiher parts; and befides, their legos are not fufceptible of a fing: And if you obferve many of them, before they be let go by their Anragonits, the Vieror retains her Ating Atill:Bur faith one, their skin is fo thin and Ms. Renmans dry, their fpears come away again withous hart to themfelves; Hift. of Bses. bur this is not fo, for I have often feen them At isken in their $c_{3^{\circ}}$ backs, and brealts, and alfo between their pleights, or ringles of 
cheir secher part, and the fting herein detained. It is esue in a grea: Caroage, reny few are itricken with stheir fang, or fpeas which they are lasith ro ule, when ther fangs will righe them; aschey will agaidt Iolects, becaule it is dead.y alio to them: felpis.

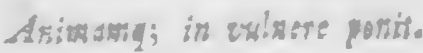

Bastheir tiogs they chicfly ufe againt men, bealts, and Fouls, for know.rg that cheir bitings are litile, or no way prejudrcial agaialt iuch able erearures, they will kill strem[elves to injure others: for their tt ng like a barbed arrow, once eased into skin or Aeth, is hoiden lo fatt, that sbey cannor diaw it cut again; and when they would bee gone, lezve therefore a part of the ir enirals iafteded co it, fo that when they ove: come by ftinging, they gets Cadmian vikory, lofeing thereby their own Ires. They are hairy almoft all over their boties, efpecially the fore-part.

A Bee hath tour drye pelluced skinny wings (and lo have all Aritosde par. Infects sthat live in fields, and wander about for their food) two sibus animal, are growirg near togecter, on either fide of their thoulders, but

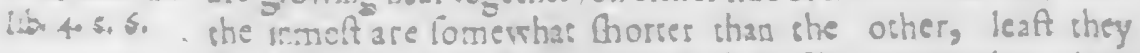
chouid hinder theirflging; and stefe (wifly convey them inso eresy place (though forre miles remose) round about their habi:ations, wanl by ofies wirg of thear, they grow som and jisged ( the isfallible cbaragers of old a ge, and death) and are unabie:o fugport ihem, yei will they veniure forch (but with the price of ineir lives' no: being abie ro retura.

The hirder past of their bodies is full of ringes, or pleights, of Cardan de whichehis seaton is giren: the beginnirg of mo:ion ma f bee in inberl tin. 9. lowe pait, which it sis were hard, could not be moved, but with the legss, as Crabb:, bur if is were all fofe, it could anuch lefie be moved, beesure there is nothing firmi and shesefore shere is a aecellity of thele ringes, that in:erchargeabiy ibe hard farts may bs mixed with the for:

Their tails ase fomewhat fhasp (the Drones more obiufe) withn which is tseis (t.nes jor r.ed :o their entrals, which ordrasity lie hid (as Griferle) leatt shey Chould bee (poiled, but bry rendjy exert, and put them our ov all occaboos ratber (as I 


\section{Theatre of Tolitisal Flying Inferts?}

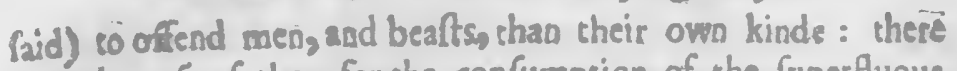
is anocther ufe of them for the confumption of the fuperlluous Avicen de à. humidity.

niman lib, $8,6.3$

They have a place for evacuation under them, and for generation alfo, as fome conceive. Her feet are fix, dew-clawed, pliant, full of joynts, hairy; and as it were, two toes at the extreamity of either foot: her hindmoft feet are longelt, that thee may put them forward to her formoft, which receive from her congue the Bee-bread, and wax, and working it on the thighes of the hindmoft, thee ftands in the mean time on the middle-moft; and though thee can, and doth ordinarily ltand aod go on all her feer, yee the two foremolt have witb her the ufe of hands, therewith hee froaks and clears her eyes, before her fetring out, but principally in her working for the difpofing of her labours to her thighs. All her feer are fcabrous, and rough, to rake hold at the firlt touch, and not that the flov:ers which they carry may readily ftick on them, as one faith; this cannor bee, for chey carry no Howers, but fuppofe him to underftand the Bec-bread gathered of Alowers, yer Aill he fails, for this is carried on the thighs, and only of the hinder Infseis $I_{1}, a_{1}$. feet.

In their head is a brain, their back and brealt is a kinde of reddilh fibrous flelh, in their ftomach, is a heart and ocher neceflary members (of which more afrerwards) in the hinder pare of their bodies, is a little bortle, or bladder (it is not in the ftomack, as Mouffot delivers) the mourh of it reacheth, or opesech iato the ftomach.

In this they carry hony, which with their heas, they defecase, purge, and concoct, whereby ir lafts longer than all Aerial Hoy, or Manna, and rarely, if at all, corrupts. Sometimes they carry water, likewile inchis botele, and not in their bill, ac- Mr. Hit Treas: cording to Mr. Hill, his expreffion, nor yet in the foft molfineffe tife of right osof their whole bodies, as hee alfo delivers; they have bur one dering Bece. contrated entral, which exiended, is as long as the body: The excrements are liquid, fluid, and yellow.

Arifforle in the Defcription of the Cbameleon, a vile (and in many Countries a Vulgar; Creature, is very exactly, particular, Iulius $C_{2}$ far and large, Scaliger having commanded this, and withed for like Scaliger com. diligence in arhers, faith, My judgentent is, rtat a Philofopher Hif. Animal. mult lib, 2. c. 14: 
soult önit sorhing, for though fome thirgs bee known co forme; ye: it is a lecret to many, wherefore, wholoever writes, feeirg hee writes so sil, mult do this common courielie to all.

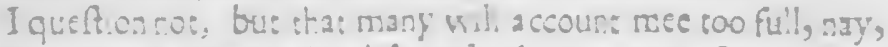
redieses mary times is this circcurle; but I carno: fout a lorg foortro a litie thece, rorenciole lo many lliads of cbersaEsstefia, eap, tions (as one ód the Iliads of Homer) in a Nur Theli; for this 21. P. 3. exculd prove an indecorwt, for though the Ese is li::le among fuch as flye, jether fru: is the chief of firees things; and thee is full of widome: ast as the great Oceai: hath in tichirgs creeving inumerabie, bo:h of imall and gieat beafts, fo do:h the Bee afford obiersations intumerabee. Polit:ca', Mo:a', Phylical, and Meraphifica', it is as wonder ther wi the F:lbere mer is ti:s Sea cansoriake ali, yer with indufiry may they rave daughe enough, and fuch plengy o: various ifeculaticns as may delght, if notiatisfie the pasien: Reader. Tco much cur:oirty may down us with Ariftrie in the boitome of the $\mathrm{Se}_{3}$, et burn us wib Ping on Mous: Figavim.

\section{CHAP. IV.}

\section{Of tor Kindes and Colears of Bies,}

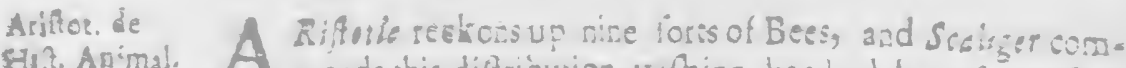
Alit. Animal. A mends this difrioution, whing bee had beenco exat in
tib. 9.4.40. other creacures, whereas here hee abounded mese in worcs, than

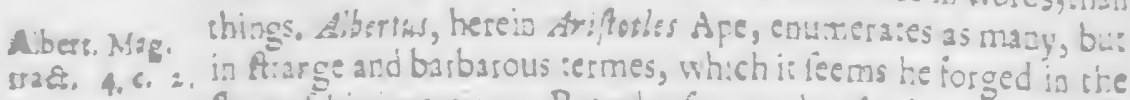
Thop of his invention: But whatoerer the Ancieris have related concening diverle kirdes, and fome Neotericks, :o appeas as knowing as ary in tomer ages, have deicilbed; wee in theie parts of the wotid ackiowledge (becaule we know) buc ore for di Dumeftick heny satheirg Bee: Some indeed live in woods, as wild, others in hives, as more iamilias and wilde; buthefe interchareably thift cheit hab:ations: And I queft:Aripor. Le corot, but he wilier (becaule more remo:e fiom the compasy Aith.lib $\%$ of menj by familiariy will frove as cectie as any. sis

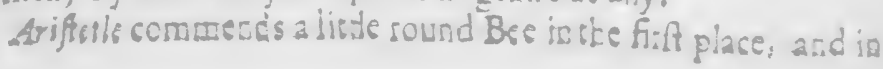




\section{A Theatre of Political Flying Infects.}

the next that which is fomewhat long, and in thape (not colour) like a waIp. But (as I faid) wee have in thele parts of Europe, but one fort of domeftick Bee. And yet Pliny, Varro, $C_{0}$ lumella; and in a word, all receive this diftribution of Bees from him; And which is more, hee confounds the Drone into ewo fores, a Thief and a Dione, which Scalliger recoxcilech well thus, thar by the Theef is to bee underftood thas which others call a Drone.

Varro cising Menscrates tells us of three kindes of Bees, one Varrode re blac's, a lecond red, a chird par:y-coloured, which hee com- suft.lib.g. mends for the b. At.

In afl the Inands of the CMolaccas their hony is made of Prgafecta. certain Fles leffe than Anrs. It is a report not confirmed by any, bur fuppofing is true, the Bees (not Files) were fmall, like unto the American Bees, and the Ants great, fuch as are in fome parts of the Indies greater than our Flies.

Moreover, there is fome difference in the bignels of Bces, but it is accidental, for they that ase loaded (cfpecially with water or honey) feem greater and longer than thofe that are empry. The Nymphs allo when they come firtt abroad are not grown to the full bignefs, which afterwards they have; and the old ones do wither and become little again.

Lisewife in thefe three Ages their colours alio do vary; for in their middle age they are brown, whereas before they are more pale, and at the laft they grow grey, or whition again, but thefe are differences of Bees in the fame hive, and not of one hive from another, fince thefe divers forts are in every Hive.

The report is, That all Bees were at firft of an Iron colour, but for feeding of 7 upiter, had this reward beftowed on them to $\mathrm{M}_{\mathrm{l}} \mathrm{y}, \mathrm{h}$. bee changed into a golden colour. But not to infitt upon Fables.

In fome Countries there bee white Bees, Ariftorle laith, in Postus. Many luch are in America, noc becaufe shey are thinaer, or of a more tranfparent fubftance, or feed more finely as fome, rather they are a fainter and feebler kinde of Bees, for L. Verulam white is a penurious colour, and where moyfture is fcane, fo Silva Silvantutra blew Violers, and other flowers, if they bee ftarved, curn pale cent. I, s. and white. Some affign this as a caufe of colours, the ex- 
mentirious moyfure, which as it paffeth through a courfer, or more fine, and delicate Arainer, fo are che colours brighter or dakker. Others, Bees are not therefore brown or black, becaufe Card de ve- their thinfubftance is eafily dried, and that which is burnt and rictatrer.c.28. moift as a coal becomes black. Nor are Bees of one colour more than Wafps, becaufe they feed of fewer forts of food, than Arif. degen. Waips : Fur colours are difpoled unto all things by the great animal,1.s.e.6 Creacor, of whichno more certain realon can bee given, then why fome men arc Negroes, others are not.

Now Negroes are rot black by reafon of theirfeed, this is confuted by Ariftotle; nor yet by the heat of the clymate, for Seldens il. this is confuted by experience, in that Countries as hor, produce
luftraton Drsy t. Poly. albion. to rong. of a different colcur, who can cerainly thew why abour the Magelarique.Siraits they are fo white? about the Cape de Buon Speranzs, when as in the Eaft. Indian Ife, $z$ eilar, and the Coaft of Malabar, they are black both in the fame parallel. Oneficritus: Nor of the foyl as fome have fuppofed, for neither haply will pud Serabon. LoI.

Sards $R \in$ lat. lib.2. cther races in that fcyl prove black, nor that race in other foyles grow to bee betrer complexiored; but rather upon the curfe of $N_{\text {a ab upon }} \mathrm{Cbam}$, or the polterity of $\mathrm{C}$ bus. But of this can siee bee no more affured of than the former; for $C$ bus inhabited a part of Meforotamia watred by Gyor, a river of Paradife, and one of the branches cf Fupbrates.

Some leaving the ho: impreffions in the aire,a:tribute it to the driness of the earth, as chough the Lityon Defarts were not more dry (and yet the people no Negroes) than many parts of Africa, where they are all blacts.

Some afcend above the Moon to call fome heavenly contellation and influence into this Confittory of narure, and there will I leave thera; yea, I will fend them further, to him that hath re ferved many fecrets of nature to himfelf, and hath willed us to conter: our felves with things revealed: As for fecrer things both in heaven and eartin, they belong to the Lord our God, whole holy Name be blelfed for ever, for tha hee hath revealed to us things molt neceffary both for foul and body in the things of this lile, and that which is to come. 
A Theatre of Political Flying Infects.

\section{CHAP, V.}

\section{Bees naskre and properties.}

REES are neicher abfolutely wilde, nor altogether tame creaare not (as fome conceit) ignoran: or ne gligent in gathering honey, and framing their combs, but yer ferviceable in meaner imployments (as fetching warer, watching, and warding ) but all are naturally skilfull in all their proper labours, and interchangeably perform them. Their lting is more often the caufe of their ruine, than inftrumental for their relief; for loofing it (which chey alwayes do when they fting) etey unavoydably lofe theirlives; but with the fear of it they often chafe away timorous perfons from their Hives.

Some fancy that the caufe of their humming noyfe while they Alye, is, leaft they hould bee deprehinded for theeves; whereas the robbing Bee, or theef, boldly difcovers his purpole, as foon as hee comes aear the hive which hee incends to affault? with a loud threatning noyle, proclaiming their deftrution, if they hall refitt, and not willingly permit their goods to bee plundered, endeavouring by fear to berray the courage that felfprefervation hould arm them with.

That fome Bees ftay at houne to receive the labours of thefe Arit.in bittor. that go to work (as Ariftetle delivers) is but a fable; hee Animol $\rightarrow$ c.4s. faitl the Bees returaing from their labour, Thake themfelves, and three or four attend and follow, and eafe them of their burden.

That they sarry in a windy feafon litele ftones to poife themfelves, is a falle relation, yee in a ftorm they will help themfelves by flying under the Lee-fide of an hedge, or encompalsing a high and hilly place (if there bee any) and fo as it were by making a board (as Sea-men (peak) rake the advanrage of the wind. Bat if it bee a plain Champaign Country, where evalons avail notbing 3 then if the wind blow ftrong againt them, they figelow, and almoft clofe to the ground, and reft ofren.

Arifrosle fai:h; The fmaller Bees are more induftrious than 


\section{A Theatre of Political Flying Infects.}

the greater; his reafon is, their wings are worn and jagged, their colour blact's, and their bic's bowing, when faith hee, the greaier are fmoorh and beautiful (like idle women) when indeed they are originally of one magnitude, but growing old, their bodies, are fmall thin, and grey, and their wings corn and tattered, a certain fymptome of an approaching deach, whereas the others beauty, and luftinefs is a Crylis of their youth, not their idlenefs.

In the morning they are huthe and Atill, faith Ariforle, untill one (furely the Matter of the watch) with two or three loud buzzings cal's them all up as it were to work : But no fuch exciting found could I ever hear; nay I am confident there is none at all. But fome fuch like thing is practifed by the Apes which Come have transferred to the Bees.

Capr. Joblons Near the River Gambro in Alrica, and in many other places Colden trade. it is certain, that the Apes gather together towards night, fome hundreds in a company, and in the trees (efpecially near the Rivers fide) dance their Lavolita's, and perform many Arange Garbo les; bur about the fetring of the Sur, one of the company (cailed by the Englifh Mr. Conftable) with two or three loud voyces ceafeih ali their difports, and afier that they continue quiet and filen: untill the next mornirg when by a like voyce hey have likerty given them to play and recreare themiclues.

When the Bees likewife return from work, they are (as Ariffo:le, and others) a while in a cumulicuous hurly burly, and then by degrees make lefs noife, and lefs, untill one Aying abou: gives notice as it were that they mutt all to neep; but it is nothing fo, for in full Hives in the lacter part of the Spring,and in the heat of Summer, they make a great buzzing found all night. Bees iive in a Marrial dícipline like Souldiers in a Garrifon, fome aloraies warching and warding underftand i: of the Summer feafong, when the chilling cold, or nipping froft doth not forse them into their Hives : yet in the day time they continue it longer.

A hot Sun-fhine or warmer aire (even in Winter) will quickly prompt them out of their Hives to take a fhort vagary near their ftalls, but if the cold bee incenfe, they are quieffent, if cot dormant. 


\section{A Theatre of Political Flying Infects.}

Bees are indefatigably, that $I$ fay not covetouny laboricu, alwayes working, but never fatisfied, alwayes toyling, but never coming to a period of their endeavours, fil never at their journies end, being impoffible to bee ftuned, and the longer they work, the more ca reit they are, and impatiens of delayes, or loyterings, while there is matter to work upon in the felds, and the weather is fearonable. Nay if the flowers decay and grow fanty; The Stocks that have enough, and to fpare, will to keep themfelves doing, rob from their neigho bours.

For every Hive, or Commonwealih, endeavours to bee a Non-fuch, and to engrofs all within its own citcumference, and by any means to make it felf the increafing figure, though toyl, and reftlefnefs continually attend it.

They are not offended with red coloured cloaths as fome affirm, nor yet inebriated with fweet oyntmeats, no nor much offended with ftinking favours: I have known twenty Hives together ftand againft a dunghil divers years,and thrive and profper well, yet would I not perfwade any to fer them infuch a place if hee can provide anather.

They exprefs not more love to their keepers than ftrangers, but they being ufed to them with greater confidence venture among them, which fome (more fearful) beholding fancie, that the Bees refpect and love them more than Arangers; whereas would they boldly come among them, nay take them in their hands, and carry themfelves peaceably towards them (except when they bee irritated and offended before) they thould finde all love and favour from them. They feed not on any $\mathrm{Ach}$, nor need Pyibagoras cavea:s for that purpore.

That fome Bees gather not honey, but water for the King, and his guard, is a meer fable, for they mutually perfom all imployments.

That there is luch an order that the elder Bees Chould have 2. proper place in every Hive, and the younger another, peculiar to themfelves, is (as molt of the opinions of the Ancients) a fabulous narration, for they arc all promifcuouny mixed to gether.

Bees (as many other Infeas) have neither vifible bones, nor Cartilages, nor Nerves, nor fat, nor Aerh, nor a brizile fiell, Elian lib.: cip. 10. 
as fome land, and Sea.creatures have, nor that which may bee froperly called a skin, bur a body of a certain middle naeure between all thele like to a dry Nerve, but tar fofier.

Their body is divided into three principal parts, and there is motion in every part levered one from another, fo that whatfoever is the reafon of their life, it is not fised to any one member, bu: in the whole, and therefore Pliny was deceived, who accorás in the former, but denies that Infects, and therefore Bees have any fymptome of life by motion in the head, excep: it bee cuc off with the brealt. Ariftotle taught him this leffon, which

Arift. de hitt.

Animal 1.4 . c.6.

withou: trial hee took upon truft (as many more.) And Scaliger alco after him, and is not content to entertain an errour, but inScalig. com in foulin the brain.

folently infults over Galen, for placing the chief refidency of the loc.

It is true, that the head's of Eeles and Snakes cut off, live L.Verul. cent. not long, when as the body lives a great while; nay a fpeedy 4.4:0.

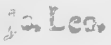

Cardede fub. $t i^{5} \mathrm{ing}$ way to kill an Eele, is to peirce her through the middle of her tail. Upon diffection I have found that onely the head being cut off, the horns, the chaps, and the tongue allo will Atir, and that a great while after the leparation from the body. Now the reaion hereof may bee this, Bees have the fpirizs diffuled, amolt all over, and therefore they move in their feveral peeces, whereas men and beafts move very little time after their heads are off : And therefore it is certain, that the immediate caufe of deach, is the refolution or extinguifhment of the fpirits, and that the deftruetion or corrruption of the Organs, is but the mediare cause; but fome Organs are fo peremptorily neceffary, that the extinguinment of the fpirits doth fpeedily follow, but yet fo, as there is an interim of a fmall time; but for Worms and Bees the pirits are diffufed almoft all over, and the refore they move in their feveral peeces.

Further to illultrate this, Fobn Lso, reports that men con. dsmned to fuffer death in Egypt, have lived a quarter of an bour, diviced afunder fer upon a heated Caldron, fprinkled with untaked lime, and underftood, and given anfwers.

A living creature is fenfible in every part, fo that it can exercife is in regard of heat, and can alio perform in every office tha: the organ, or inftrument for that office is remaining; and hence are derermined many concroverfies. 
Some query whether a living crearure can fublit without the head, ochers wherher withour the heart? Without the head they are not fenfible, but live; without the heart they are fenfibie, but the heat quickly decayes, and mosion, and hie alfo.

Bees revive eaflily when they feem dead, being brought to the Sun or fire; the caufe whereof is (as before) the diffufion I. Vient sita of the vital (pirits, and the eafie dilating of them by a 1 tele sil cens? heat; they fir therefore a good while after the ir heads are off, 69 and that they bee cut in peeces, which (as before) is caufed for that their vital fpirits are more diffufed throughout all the ir parts, and leís confined to organs, than perfe a creatures.

Awz f fine mentions the fame with afton: hment and wonder, Auginf. liv. dz fuppoling that norealon can bee rendred for it, but that it is a quaratir. anim, fecres work of God, left one ioul thould feem to bee divided into fo many parts. Ariftolle faith, thai Infects are mott like partio. aninul, plants, becaule they have many beginnings in their effence, for lib tes as plants cut in peecer live, fo Infects for a time, but planes more fully.

Bees when they flye iff themfelves up; thus they do when Arift de hifto they arife from the Hive, but they canflye forth-righi, withour anim. $14, c, 9$ asy vifible elevation of themfelves. Aldromandus would give a reafon for it, becaufe, faith hee, they want a taile, and therefore consinue not long in the aire. But this by experience is found to bee otherwife, and birds chat have lor zeates, ve" have a jumping motion in their Alight, as the Wagaile.

When the Hives are full of Bees, and well lupplied with meat, neither moths, nor any other hurtul creature can much endanger them; but when they are few and weat, they eafly mifcarry by every adverfary; fo thac it is nor a figne of a bercer fore of Bee, as Ariffotle delivers, but onely cf want of numbers or Arength, when they neglest their own prefervation, which fometimes they having formerly endea roured, and findirg their labours frufrate, they grow defperate and carelels; bu: theugh in number they bee bu: few, and therefore their dangers mary; their provifion litule, and therefore their fare poor and pinching, yet will they not forrake their own Commonwesl th to communieate of the wealih or ftrength of others, but without repining reft consented, yet by dijgence endeayouring to im. 
prove their fore and numbers. But when they are fo few that they cannot shrive alone, they will with a general confent (exceps their Generals, to whom fuch a relolution is deadly) lonctimes joyn themfelpes to another Hive, but alwayes with hazard, often with deftrection.

Bees delight to play abroad before the Hive, flying in and out as thick as if they were fightirg or fwarming, in breeding cime, once a day ufually, if it bee tair weather, and ordioarily at a fer time, each Hive obferving the fame hour of the day if it bee fair ; and then they will expatiate and dance the Hay in curclirg motions, and furrounding Vagaries; and at cther simes when they have been long fhur up with cold, or clofer weather, the fir ft fair day they will thus abroad both to recrease themfelves, and alfo to eafe their bodies, for they evacuate for the moft part flying.

\section{CHAP. VI.}

Bees Politicks, Eibicks, and Ecoromicks.

Ne drop of water hach no power, one fpark of fire is not Atrong, but the gathering rogether of waters called Seas, and the communion of many flames do make both raging and invincible elements. And ura Api, nulla Apri, one Bee is no Bee, but a multitude, 2 fwarm of Bees uniting their forces togecher, is very profitable, very comfortable, very rerrible, profitable to their owners, comfortable to themfelves, terrible to their enemies.

Bees are political creatures, and deftinate all their actions to one common end; they have one common habitation, one common work, all work for all, and one common care and love towards all their young, and that under one Commander, who is

Bafl. Concio in Gordinum Martyr.\& nor an elected Governour; for the vulgar often wane judgement, raifing the wort and wickedeft to the Throne; nor hath hee his power by lor, for the chances of lots are abfurd, and riHexamer.ho- diculous, conferring command often upon the meaneft: Nor is mil.s. hee by hereditary fucceffion placed in the Throne; for often through pleafures and tlatieries are they rude and ignorant 
of true vertue, but by nature bath hee the Sovereignty over all, excelling all in goodlineis, and goodneis, in mildnefs, and majefty.

They have all the fame common laws, and with common Ambrol. Hexcare, obferve them all, and have one common bond, noe to am.l.s.c.21. have any thing lawful for one, which is nor lawful for another, but whatfoever is lawful, is lawful for all. And they have one common refpeet, and reverenee to their Commander by whofe counfel their Commonwealth is governed; a common houle, a common care of pofterity, common labour, common food, common generation, a common ufe and fruition of all thinge.

A Bee, like a man cannot live alone, if thee be alone, thee dies: J. Stobsuslaus As in the Fable of Menenius Agrippa, the whole body foon nuptia..p.67. perifhed, when the reft of the members to eafe themfelves wronged the belly; to the whole Commonwealth of Bees will quickly bee diffolved if they labour, each Bee for her felf, and negleat the publick. Nay the Drones', though they bee idle, yer are ufefull intruments for the good, and prefervarion of the Commonucalth.

The Polity of Bees is admirable and imitable: Plato and Cisero after a divers manner prefcribed the form of a Commonwealth, one how it ought to bee, the ocher how it was of old, but both lay down this as a maxime, that a civil life thould imitate nature which is the beft infructer. But what is $\mathrm{N}_{3}$ tures leffon, the irrational creacures beft exprefs, and chiefly Bees, and therefore Plutarcb fends his $\mathbf{T r}$ ajane to Virgil, that hee might borrow a civil life from the Bees. For a civil man by natures rule is alwayes chiefe of the City, as the Commander among the Bees.

And again, hee faith, Bees conferve community unto their laft, for no man ever faw a Bee degenerate into a Drone, which Plutarchoan fir geren. fome require of Civil Goversours, that the vigour of their refp. age being palt, they hould live idle at home. Greas fpirits degenerare no'.

They exprefs if not great reverence, yet I am fure great love to their Commander, without whom, they will bee, they will Pet. Matrhew do nothing, and with whom they will bee any thing, go ary continuat. Gen whither, ftay any where, bee coniens with apy thing. 
entred their City, by a fymbole or type thus expreft his cle- Baptift Manmency, wearing a coar full of Images or pictures of Bees, and tuan in exhort this Motco written upon it, Rex mucrome caret, the King wants ad In'ub. or ufeth not his Ating.

Their Ethicks and Economicks appear in many particulars. They make frugality the bafis of their fubfittance, and therefore as chey laborioully gather fore of honey they thut up the Cells ftillas they fill them, and untill Winter come, will not open them, but live in the mean time of Bee-bread, and fuch provition, as they get abroad, left if they fhould prodigally wafte while rbey may work, they might after Atarre when they cannoe wurk. And in the pleafures ot this life they are fo moderace, that perfect temperance feems to relt onely in them.

They are neat and cleanly creatures, never fuffering any filth or excrements long in the Hive, empeying et:emfeives alwayrs abroad. And if in the Winter while they are weak, and roc able to indure the colder aire, filth bee contracted, yet as foon as the Spring comes, and they grow numerons, and Atong, they diligently cleanfe their Hives, and carry out all.

Their cleanlinefs alfo thus appears, That they will not fuffer their dead to continue long in the Hive, but carty them forth to burial.

Their chafticy is admirable, for whereas many other creatures couple togecher openly; Wafpes alfo and Humble-bees, and many fors of wilde Bees fcarce Ipecifically differing from them, yet whatfoever the Bees do in Venus lervice they at in fecret, and far remote from the eyes and knowledge of alt men.

The Poets fay, That this is the reafon of it. Saturn the husband of Op;, and father of $\mathcal{J}$ upiter, was wont to devoure his own children when rhey were brought forth(the realon of it was, becaufe Salwrn was named the god of time, and all times paffing and returning, revolve again into themfelves) which gave oecafion to this nittory; when fupiter was born his mother Ops fearing the cruelcy of her husband to him, concealed his birth, and the Cretans for fear that Saturn fhould hear the childe cry, rung their brazen pans and kertes, which noife the B:es following, carne to the place ${ }^{i}$ where the Infane was, 


\section{A Theare of Political Flying Infects.}

and fed him there with honey. Zupirer for fo great a benefit, befowed on his Nuries for a !eward, this admirable gift, that they Anould have young ones, and continue their kinde withoue wafting themlelves in Venery.

Mz,May An. Others report that 7 upitsy being ml chin love with a faire notst. on Virg. Nymphcalled Meliffo curned her into a Bee, and for her fake Georg. beftowed this, and ocber privileinges o.rche Bees.

And they are not lefs valiant than chatte, though indutry and diligence may do wuch with all other creatwres, yer little wi:h thefe, no not to palliate their fierceners, let them bee exafperate d near their Hives, you may as eafily binde a Lion with a Grgle hair, as by oppofision and reliftance, compole and quiet them, though the creature is but litele, yet virtur nox minime. Is it not Atrange to behold fuch a litele Infert to conm tend with the moft mighty, to fee fuch vigour in a creature without bones or feales, or hird defences, and yet to bee offenfive to, nay prevalent over the molt Atong, and powerfull (x:3:ures!

Mur.Buller Invalourtherefore, and magnanimity they furpals all crezFensin. Monar. tures, there is nothing fo huge and mighty that they fear to Esp.: fer upon, and when they have once begun, they are invincible; for norhing can make them yeeld but dcath; fo great bearts do :hey carry in folittle bodies.

In private wrongs and injuries done to their perfors, for which caufe men will focneft quarrel) they are very paticnt, but in dea fence of their Pincels and Commonwealth, they do moft readily enter the fieid,

Virg.

$$
\text { -.. For them they b:zzard de.th, }
$$

Andrbink in Warthey zob.y lofe tieir brearob.

Their War whatoever fome fay to the contrary, is onely forreign, for though in the fame Hive, by a violent or accidental congreffion of wo fwarmes, there bee lomerimes a deadiy conrelt, and bickering, yec ftilf it is forreigne, for they were never united under one Commar des.

Th. cy never fight (whatfoever fome unexperienced Obfervers Moufie: Thes- report) for food, nor fall out among rhemfelves for meat, bus trum Infce. alike communicate of all they have (shoughbutlistle) and 
when it is lpent (if it bee no gathering (ealon) Aarve alcogecher.

Their Geometry appears in the fabrick of their combes; and cheir Aftronomy in the knowledge of the weather, for they fore-know and prefage windes and ftorms, and either keep themfelves in their:Hiver, ,r go not far, perhaps fetch water, and quickly retutn.

Whes they flye not far from the Hive, but flye about it, the Thecphrat. weacher being ferene and fair, it is an ufual coken of-an ap-1.r.de fig. proaching ftorm, or tempef, A ratus prompied him (if not ex- tempeftat. perience) with this oblervation.

But above all, one excellent skill they have, which the molt experienced females, ihough they much defire it, muft yeeld themfelves to want; for they know cercainly when they breed a male, and when a female, which appears by this, that they lay their Cephen-feeds in a wide comb by themfelves, and the Nymph-reeds in the reft, which are of a maller lize.

In their own Commonwealth they are moft juf, not the Jeaft wrong or injury is offered among them : but I cannot commend their juftice tow ards Arangers, for all sbar they can catch is their own, unlels they may bee exculed in this refpect, that the Bees of divers Hives are at deadly feud, or rather as Kingdomes that are at difference one with another.

If Bees, creatures without reafon, have fuch Prudence, Provldence, Fortitude, Chattity, Loyalty, Natural affection, fuch Government, Orter, Difcipline 3 How much rather ough men to exprefs the fame in their carriages and converfations. If they abhorre Incemperance, Luf, Sloxth, Rebellien, Cowardife, thallmen practife them'? They aie then worfe than Brutes, and deferve rather to bear the names of favags Monfters, than of civil aad realonable men. 


\section{CHAP. VII. \\ Of their Semjes.}

Cirdin. de Subtul.l.9. Plinwat.Hit?. I.1I. C IO. Aritt. de Hift, snimal.l.4. Sealig. com, in Aritt.de bir. $2 \pi, 1.4 .6 \%$

M:.Burler Feminise Mona:ct.

CRearures produced of putrefaction are little, and weak $\mathrm{A}$ in the fenfes; deteetive in their exteriors, much more in their interiors; yea they altogether want wildome, and ase ftupid. And therefore Bees are prudene, becaufe they are gewerated of $a$ certain matter, and not without a parene.

Bees have all the five ferfes, though there do not appear all thofe outward Organs of fenting, which Come other Animals have: And fo likewile Fithes have no vifible Organ of hearing and fmelling; and yet hear ard fmell, ethere is porfeen perfectly in their heads a brain, yet is 10 the beginsirg founcaio and feac of all thefe fenles, phantafie, and memory.

Of all the five fenfes their fighe feems weakeft, yet is it dear, eipecially atar cff, which guides them abroad, and direets them home, though fometimes they are three or four miles from their Hives,

Bu: their fighis is no fo quick near hand; for fometimes stey will Aye againlt you, if you come fuddenly crols them when they are laden; and alfo near the mouth of the Hive, if they light befides the door, they will run up and down feeking for iig as if they were in the dark (hereby verifying this truth, Thar things neaselt the eye are furcheft from foght) but then up sheg rile, and Agring back a liele way, turn again with a betrer vieu:

As macy as fall befides the ftool when it waxeth dark, ten to one bur they lye abroad allnight; yea if at fuch times being stoubled by any thing, they come ferth our of the Hive, although they bee freh and lufty, they will leap up and down, rus, and Aye ro and fre, untill they bee weary, bur by no means can they finde the way in again.

And therefore it is, that when they flye abroad theg take much pains at the door in rubbing, and wiping their horney eyes, that shey may betier difcern their way forth, and back again. 


\section{Tbeatre of Political Plying Infests.}

It is faid by fome of the Ancients, that Infees have onely the fenfe of feeling, which is manifeltly untrue, for if they go forth right to 2 place they mult needs fee.

Their (melling is quick and excellent, for ehey will fent honey a mile from their Hives, and make hatteso $i t$, and when they flye aloft in the aire by it, fent any flowry Mead or Heath near them.

As foon as the hony-dew is fallen, they prefeatly fent it, although the Oaks that receive it bee afar off; which the Poet (ipeaking of she excellency of this creature in this fenfe) thus exprefteth,

$$
\text { -..-I Ileogue per axras }
$$

Mellis apes guam longe duckntur odore.

Iucres.lo 4 .

Their feeling is as active as their other fenles, nay more, for it is moft individuate, it inheres in the fubffience of the creature, and cannor bee leparated, or taken away without the detriment, Third Efray of or utter decay rather of the fubject whercin it is. It may Touching. therefore bee called the living lenfe, although in divers difeafes and occurrences alfo oft-rime befalling the fubject wherein it is, it may be deprived of it. As we read of Atbenagor as of Argos, whonever felt any pain when hee was ftung by a Scorpion.

Their feeling is fo quick, that if you do touch a Hive very loftiy, or knock upon the ground near the ftool, shey prefently refent it, making a general murmure, and many of them coming out of the Hive door, as it were to examine the caule.

And for their tafte, this is evidently as active as their other fenfes; thereby they mutre choice of waters, and all ,ocher gatherings for their ufe and purpofe.

And laftly, for their hearing, that alfo is good, though Ariftotle doubes of it, nay denies it. Cardan faith, That Arif dehift. Becs, becaufe they are fo fmall cieaturcs, cannor hear and fee an.l $9 . c_{4} 40$. too; but being fijing creatures, there is a neceffity of feeing, Meraph.lor.c. Th and therefore an impolsib lity of hearing; but hee contradiets 1.9 . himfelf, when lee tells us, though untruly, that every morning Id en de varie(ali being yet filen: if not afleep) one (the Crnttable fure, or talverum l.7. the Mafter of the Watch) by two or three Bombes or flurill founds like a Trumpet, calls themall up to their work; and fo 
Virgil.

likewile in the evening, flying about the Hive, with a frall humning murmure commands them to fleep.

But if Bees hear not, to what purpofe is the calling before they (warm, and alfo their encouragements in fight,..-

\section{..- And then a voyce}

\section{Is heard refembling Trumpers winding noife.}

Scalig. Com- And Scaliger acknowledgeth againt Ariftotle, that they thear ment. in Arif. figna snim dant inıus, alia at que alia etiam for is, mwtato mar: de Hin, animal. mure.

3.9.6.64.

But in a word, further to manife?t that they hear: If a fwarm rife, and the Queen Bee mifcarry, and fall by the way ( 2 s it of happens) her company notwithftanding will lighe, expecting her coming. But being hived, they prefently mils her; and with a mournful murmure bewail their condition. Some run up and down diltractedly wichin the Hive, others without 3 and by and by making 2 fudden ltop, fall into a palsion of mourning, and then run up and down again, and then mourn again, but in the mean time they fend many to reek for her. I have ofren found her where thee hath been fallen, and raking ber up, carried her to the Hive, where I have obferved (not without admiration) how that at her firf coming they have in a moment changed their former note and carriage, and with clapping of their wings, and a rejoycing murmure congratulared her prefence; and thole that were feeking about for her, although fome rods diftant from the Hive, in an inftani, as it were, recurned all home, and with a rejoycing gratulation welcomed

L. Verulam. Silva.filvar. cent.7.698.

F.Picolomin. univerfa fhil. de encribus. their Zueen. And therefore they have hearing, which thew's likewile, that thoughtheir fpirits bee diffuled, yee is there a Seat of their fenfes in their head.

And as they have the outward fenfes, fo have they the inward alfo, elle could they not bee wife and prudent; underftand wifdome or prudence equivocal, fo called by seafon of the reIemblance it hath with true wirdome or prudence, being able to finde out, and to manage convenien: meass unco nacural and felf-ends.

Vertue is not taken or underfoed one, but many wayes, fomerimes for the thadow, and a Aligh: or light refemblance ibereof, in which fignification Bees are called prudent, whereas prudence properly fo called, belongs not to them. 


\section{$A T$ heatre of $P$ olitical Flying Infects.}

Bees have memory, which is not a fenfe or imagination, or underttanding, bat a difpofition or habit of sny one of them, when the time allo is joyned, or added to it, wherein the imLea. Antiq. lib.20.csp.3. prefion is made, and the vifion is left in the minde; whence this is a conlequence, thofe creatures have menory, which have fenfe and underftanding of time, for wee remember onely in the fenfual parc of the minde; for if a horfe hath been mired in a flough, when hee meets with the place again, hee will prerenily remember that hee was shere mired.

And herein Brutes differ from men, That a reafonable creacure doth not onely remember that hee hath feen, or heard, but lfo differenceth the fpaces of the prefent time, from the time pait; but Bruces onely know thus much, that th:y have fallen (into a pit, or other dangerous place) at this prefent, or fometimes formerly.

Again, a man obferves that hee remembers, which irrational creatures do no:. And among all living ereatures they have the belt memory, which have the molt clear,pure, and perfect imagination, of which fort are Bees and Pidgeons.

As fome creatures befides fenfe, have memory, and natural prudence, fo fome go furcher, for they are difciplinable; but none have experience, or very little.

Now by fenfe wee are co underftand that fenfitive knowledge which is onely in the prefence of the object, whether it bee by the internal fenles, or by the outward common fenfe or phantafie: For under the name of fenfe, the Philofopher comprehends whatloever is neceffary to perceive or underftand in the prefence of the object, but there is meceffary in all, fomewhat of the phantafie or imagination, to underftand even that whick is without. And therefore it is common to all brutes, is to underfand, fo alfo to have imagination; but memory addes an inward Atrength, and power of conferving the fpecies and ufing them in the abfence of the objects, that by this means any thiog may remember thole things which it takes in the fenfe, even then when they are not prefent, in regard of the externall fenfes.

This faculcy, faith Ariftotle, fome creatures have, but not all, but yet hee declares not what creatures have, or what want ii. They are commonly thoughe to have memory, which E 
may properly and pirfectly bee moved frem one place to a more remcie, either by a frogrelive moricn on the land, or Alyirg through the aire, os fwimirg in the waters, for nemory feems for th:s furpole to bee given to creatures, that they may bee removed to a diffane plase, either to avoid that which is noc ve and prejudicial, or to finde that which is uffiul, which they have any wayes made trial of.

Further, fome creaures, faith Ariforieg with memory, have Fiuderce, which (as wee faid before) is ror to bee underflocd propery. bu: merafhericaliy, for shey ufe not difceurle, ror ac= qu te a babir, whereby they may judge of what they are co do; but ofien mes lo aet by a nacural irftind, and lo provide for the furure, as if they had realon indeed, and therefore by a figure are cailed prudent.

And this prudeoce of Brutes is a fpecial fagacity in fome, which by the inltret of rature, are lo ordered as ihat shey feem to im:ate the reaton and priderce of men; but all brutes have no: this pruderce, but thole creaturesthat bave it, are fo pesfect, that they have all of the memery.

And wee may adde further, that this nacural lagacity, thea Eliet : ments she rame of prudence when is is traired up, and perfected by the memcry of former thicgs.

Some creacures have no: ore'y memoiy, bu: are alfo difcifliable, but othersare not: Oi this lalt rantse are thcle, which though they hare memory, want the lenle of hearing, for hearirg is the tinfe of difcipize; for wee le many creatures, dogs, and horfes, act by exicros! figne, bu: never withou: a co-cperation of hearing, wherby they are called and firred un to uza deritind the fignes.

A if. Metapt. Now Ariforle $1:$ is down an example in Bees which hee lupIbicapor. folfd no: to hear, Bue Plisy, Scaliger, and many others affirme the conerary, and by gcod arçmens picve their AfSer:on.

Alberius willing to faive the Phitotopbers credit, invented this difterion. There is, laith bee, a hearing of a lourd, as fo, or of a wyce as : $t$ is an articulare found, now Bees bear in the former way, not in te later; but this latter hezring, fath hee, is nceefiry to make a creature difciplirable; but xhe: her many draptinable creasures fotsar,migbt bear a great gueficp; 


\section{A Theatre of Political Flying Infects.}

for alcbough when they hear fuch words or founds, they come, or fly: dow 1 , or fp:atsafeer the fafhion of men, yet are all thefe things dare by a narual in?tint ( fuppofing memory, and the experience of fuch a lign, of voice.) And therefore Suarez Fr.Suarez faith well, I: were bitcer to fay all creatures which are difci-Metaphadifar. plinable, have hearing, and perbaps fight, memory, and a metaphorical prudence or (agacity. But to leave thefe nicer difpures, (as perhaps by fome fuppofed) impertinent to our prefent D. fourle.

\section{CHAP. VHII. \\ Of the 2reen-Bee.}

THe Queen Bee is a faire and Aately creature, longer by the half, and much bigger than a common Honey-Bie, ) $e^{2}$ no: fo big as a Dione, but fo mewhat longer. She differs from the Common. Bee both in Thape and culour; her back is all over of a bright brown, her belly even from the sop of her fangs, to the tip of her train, is clear, beaurifull, and of a fad yeilow, fonewhat deeper than the richelt gold: Her head is more round than the little Bees, by reafon her fangs bee thorter, her congue is nor half folong as theirs; and thereby nature hachdifabled her for working, for it is impoffible for her thort tongue ro extraA mucb out of any flower, were thee never fo induftrious.

Her wings are of the fame fize with an ordinary Bees, and therefore in refpect of her long body, they feem very hort, rerembling rather a cloak than a gown, for they reach but to the middle of her train, or necher part. Shee hath Areighter, and Aronger legs and thighs than a Honey Bee, which are of the colour of their belly, but her two hind-legs more yellow. Shee hath a lofy pace and courcenance exprefsing Majefty: That Thee hath a white fpot in her fore-head gliftering like a Diadem, I never faw, though it bee frequently reported: Nay I am fure of the contrary.

Her nether part is much longer than her upper part, and more tharp than any ordinary Bees, having in it four ringles or E 2 
partitions, and in each ringle a golden bar in ftead of shore three. whisith rings, whicb other Bees bave at cheir three partitions. The fpeas or fing thee hach is but liztle, and nor half fo long as the other Bees, whicb like a Kings fword, is rather born for fhew and authority, than any other ufe. I beleeve they. canno we their Ating, for I have provoked and forced thers to Ating by hard holding of them, and pusting their taile to my bare hand, bur could never perceive them willing to put it forth Nay when I bave forced it out yet thee would no: encer it in my. inand.

lo a word, the Quecr Bee in ber whole thape and colour, is goodly and beautiful creacure.

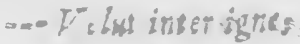 \\ Luna mirorss.}

As the Moon when in a clear night, fhee fills her circle, is gore and mare eminently beautiful than all the leffer ftars, fo is the Quees Bee among che orter Bees.

There are not swo forts of Kings, or Queens in acy Hive, as Arifolle, and afier h:m Pliny; and the roof have delivered, Asift de hirt. bui onely cne, and though a King in place and power, ye:

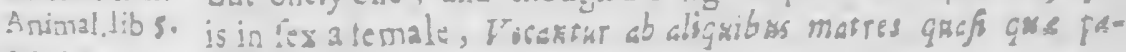
2.39.19.

\section{rismto}

That swo fevera! Queens or divers companies thould agree is the fame Hive, though div ded in their works, and neishes inerench on the oshers fubjects andlabours, although the Ancients very confiden:ly deliver it, yes ir is a meer fablt $\rightarrow$. Many * Mr. Gonge IKrgs in a Hive, but fally : As Ariforle makes two kindes. 4. Bool in of Kinge, or Queens, fo in every H.re hee wurld have ai once Iresiof Bees. [exera] Kinge, for although one bee enough for government, yes not for generation, laish Skatiger, fuppoing with Arifolle, that ihey were inftumen:al, as the males, for the generation of Bes.

Aritlide bift. The Queens cells whe rein thee breeds, are not ufually in the Animal. lit. S. butsome, or under the combs, bus on the edges, lome on the rap. 19. Sca.1g. bur in outide, fome more irward is the middle of the combs. loe. Aod they often exceed. Arifforles number, who decermines the $\mathrm{n}$ 
them to bee f $\mathrm{x}$ or feven, whereas in fome hives there are not fo Arintde hift. many, in others nine or ren.

It is a Chymerical fable that fome have afferted, that the Anim.lib 5 . cap. 19. Bees firt build their Commanders houfes in the molt eminent part of the combes, more large and beauriful than their own, and of the pureft wax, and then inclofe it with a waxen wall froin the reft. Whereas indeed neither Commander, nor fubje.ts have any particular habitations, for they live and lye between the combs, and the hexangle cells are repofitaries for food, and nurferies for generation; and the orbicular cells are breeding places for the Royal iffue.

And yer Aldrovandus delivers it as a received and ancient Andro. de Intruth shat the Queen Bees cells are made in a more emirent part lect l.1. of the hive, very large, invironed with a fence, or wall, for an emblem of their greatnefs.

And as in conditions they are of three forts, fo they make a triple divifion of their cells; thofe neareft to the Q:seens Pallace, for the molt ancient inhabitants, as the Queens guard, and next to thofe the younger, and fuch as are nor yet a year old; but to the middle fort as the molt. Atrong and lufty are committed the extremities. This is a fancy alio.

The materials for the Cueens generation are yellow, and Ariftde hif? there is not firtt a worm, but prefently a Bee, wt aiskt, faith Animal. l. 5.8. Arifotle. And Higinius as hee is cited by Colume lla, faith, the 22 Corte Columel de Commander is not procreated of a worm as othes Bees, but in re rutt.l.g. harger cells than the Honey-Bees, are found holes filled with a matter of a red colour, out of which the Queen Bees are bred, even at firtt with wings, fo that it appears there was tome glimmering light among the Ancients concerning the Queens generation, but dark and uncestain.

Know thus much, that into thore orbicular.celis is injected a Spermy master thick, like cream, but inclining to yellow, wherein and whereont the Queen Bee is bred, it being both matter of generation, and augmencation, for thee is at fitt (when thee is viribly any thing la perfeet Bee in lineaments and fhape, though not in magnitude and dimenfions, and feeds of that wherein fiee is.bred, uneil hee comes ro her perfection.

The Bees never deftroy the Nurferies, or oreeding cells of the Queen Bes,as Ariffolle delivers, and alfo Pliny, although af et 
it ey interd so (warn no more, shey bill all the Royal iffus iben

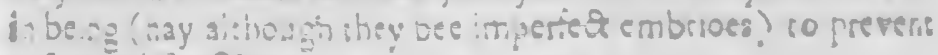
a fuscre difraction.

Betco the bies iwsm, the Queen Bะs by a peculiar and

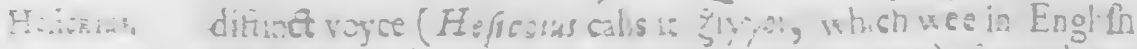
fay Sirg tor it is peformed ic a mutical manner) bome dayes

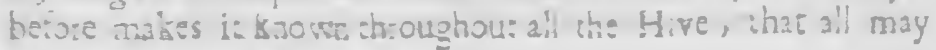
beeready

Ricisulcus is the concei: of Didinns:o pull cff ihe exiremisies af the Queea Bses wings, that they ary to: Age away", fox ometimes for recieation, and alio tor evacuation of their bocies, they li: 10 go borth; and if iteir wings were cu: ;roulit bee ciabled :o reiur.

I caie had a sad furm likely so nilicary, the Quess Bes ur cosero acciderially orn, po that gcing cut of the Hive,

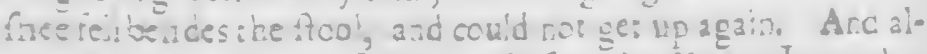
icough cace and again fiadng her before the H:Fe, I fu: her

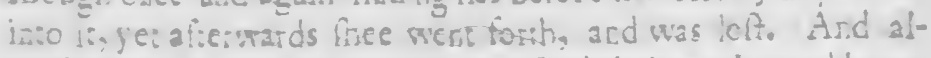
rolt ail the Bees (in her lols) meleted their work, and beoan

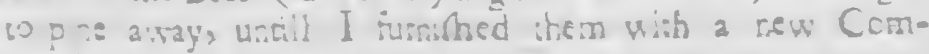
m.ander,

Tre Cuees Bee rever ralunizily; deierts her fubjects, as

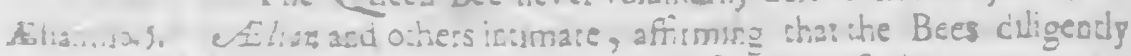
S.P. I $:$,

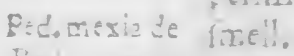
ief's he: cu: and resurs her when inee bash Aled a way.

OAer: ajes when a iwam goeth forth, the ycung Commance: beiroweak, is oo: able so to bas, but falls down, fonetmes detices the floc! or fomesimes turther cff, with whom iome of the compary whil tasy (fich as being wear her faw her fai ) scà excmpating her scurd will concrue with her, exceps

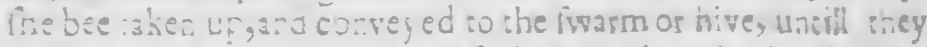
perth ingeinte. The Bees frode not their leacer by the

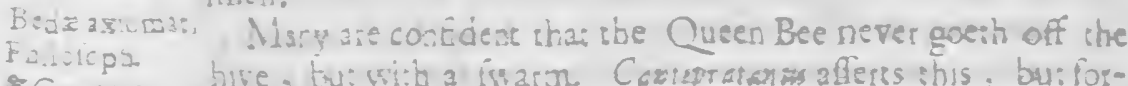

s Cari:

$10=0$ 口иm แn:-

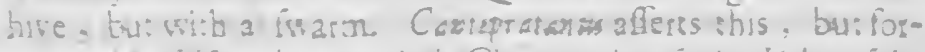
geto-g amielf in :be cweciein Chapier, kee lash, If her fub-

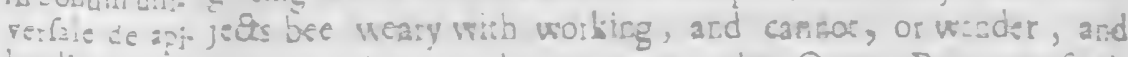

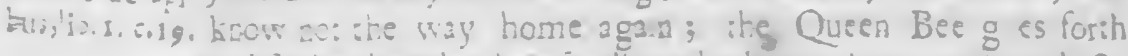
and hisutes thee by eberr mell, and releves them, and condicis inento ure hise; but this is more fabulas tbas che former. 


\section{A Theatre of Political Flying Infects.}

It is more than probable, that the old Queen Becsi go forth fomerimes wich the latter fwarm (whesher out of curioficy, or wantonnels, or indulgericy, or dillike of her proper houfe, or Jove to ber ancient fubj:Crs, I determine not) and this is the caufe of the not thriving of many old Alocks, after they have caft a lecond Iwarm; for a though the Bees that are left, bee in a well replenifhed $\mathrm{H}$ :ve, and therefore live out the Summer well, and work too, though not with that order and diligence as for merly, yez will they racely breed, bu: by degrees confure away, and come io nothing. I have exactly viewed divers Such ftncks that I have taken, and could never finde a Queen Bee among ihcm.

If therefore you perceive a hive, after is hath caft sw'ce, in: have fome quantity of Bees, and yer to work negligently, or no: to increafe in the Spring, fuipect them to want a Qucen, and fupply them withone as foon as you can, if no other way, by driving a poor fwarm into them, for which purpole alwayes referve fome.

Ii ha:hbeen a confrant sradition, that the Queen Bee hath a fpecial guard alwayes waiting on her, and that when thee goeth forth, The is alwayes attended with them. I have often ietr her to go forth, but al wayes without artendance. It may.poffibly tall out that fome Bies may go abroad with her, and forre others return when the comes back to the hive, but never as her fpecisl guard.

M.. Bwiler faith, If the Queen Bee by her voyce bids them go, they fwarm; this is warily to bee underltood, namely of the laiter (warm only; for the firft is for ought I could ever finde out; at the will of the Commons; but there may bee a tacite confeat of the Queen, but not folemaly by voyce, allowing their departure as in afier fwarms.

And again this is not alwayes true in fecond fwarms, for after the Queen hath approved of their going forth, ye: they will lomerimes refule, and manifeft their difike by mafiaring all the Infants of the Royal farmily,

I bave abferved fome few Bees in the fpring in eyery good Hive, wichcrefts, cutis, or tafiel on their heads, fone yellow, Come murrey, in manter of a plume, fome ftanding upright, fome turning down, bu in all other refre the lhe otoes HoncyBers. 
Mr. Butler fuppofech them lubordinate governours and leaders, as Captains and Colosels : They are feldome feen bur in May, and a livte afeer; that shey have any authority, or command over the seft, or ipecial place about the Queen Bee, I befeeve no:. This I am fure, I never faw ary one of them asterd her in her thore progreffes. Their working, 1 concerve wears oft this oroamen:

T.Cantipra2. The Queen Bee goes firft out with che fwarm, fay fome: bonum un ver. bui i: is not $\mathrm{lo}$, for the goeth almoft latt, fomecimes indeed thee fale de apitus, cones forth half an hour before the fwarm tifeth, with a greas lib.r.cap 34. company whicheriviron, and attend her on the ftool; but her company moves nor unt ll the oreater part are paffed out of ste tive, and then thofe chat envitoned her begin to arife, and Inee with shem.

Elian lib 5. And as in the emiffion of a Colony, the Queen Bees go no: c.18. before, reicher are they carried as any sime as fome report.

Somerimes as I faid, thee comes forch before, and Aayes withou:; at other times hee comes firt to the botrome of the ftool, and peshops out of the door, as it were chiding their Mactsnels; but then when the lwarm begins to arife, thee recurns in untill the greater part bee come forth, when hee follows, and where they ulually light, joynes her felt to them.

Bees are governed by a Queen, which masy hold not properly to come to the fupremacy by fucceffion, bur by 2 judicious and prudent election, whereas it is moft apparent, tha: the elcer of the Blood-royal goes forth with the firt fwarm, and fo the next in order with a lecond, although fomerimes efpecially in caflings, or fecond fwarms; forme orhers ventuse forth. I have known eight go forth in one lwarm, for they can but dye, going forth, and death is certain and inevirable if they tay. And a younger by dividing the fwarm, or firt? getrirg the higheft place of the Hive, may bee peaceably obeyed, with ine deftruction of all the reft.

Nay being necelsitated, their own leader milcartying in fwarmirg, or by fome accidentalterwards. I have preferved the fruck by putring to them a Queen Bee takenfrom another. And once, becsufe I would bee fure, I pared off a listle of one wirg, and fome months after, for experience rake, cook the 
Hive, where I found that Commander put in by mee, and no other Leader. So that though ordinarily the Queen Bee comes to her government by birth-right and Ceniority, yee Comerimes by election, as in the mifcarriages of their old Queen, and in fecond fwarms when $\mathrm{c}$ wo are united together.

When feveral Leaders go forth, one whofe paray prexaids gets the Throne, and all the other competitors are flain. When their proper leader by fome mif hap hath been loft, I have given them anoiher (as I laid betore) with whom chey have wefl agreed, and profpered, fo alfo in the union of fwarms.

And although they are willingly fubject to a leader, ye: do they not altogesher lofe their liberiy ; for the firf fwarm goes alwayes forth at the will of the commons; and although the fecond, and allo the third, mut have the Regal affent which ulually (being indulgent to their iffue) upon pecicion they grant; yet if the Commons fee it not convenient to diminifn theit nurabers, upon the Queens grant, they kill the Probationer, and ail of the Blood-royal; fo that Prerogative ayals litcle in the Commonwealth of Bees.

The Queen Bee (for it is an Amazonian Commonweatch) tcanfcends in greatnefs and beauty of body; but which is molt praife-worchy in a Commander, in mildnels and genclenefs, therefore though they have ftings they never ufe them, which the breeding or mother Walp doch, Itinging more venomouly than the fmaller.

The Laws whereby this Commorweal th is ordered, are na tural, not written in letters, bus engraves a therr manners; and fo Pudious are they of peace, that neither wi'lingly, nor unwillingly do they offer injury to any of their Cubjects.

Who will not hate the Dionifin of Sicilia, or the Otraman

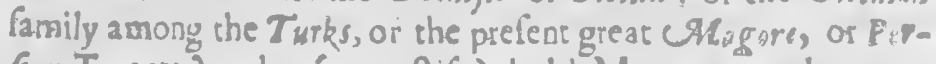
fran Tyrants? who (in practife) hold M ia cily to bee $110-$ thing elfe but 2 lawlefs exorbitancy in all manner of lufts and mifchiefs, which ought to bee fas from a good Prince, left winle heefeems to bee a man, hee difcovers himfelf to bee far worfe than thefe irrarional Infects.

And as their life is not vu'gar, fo neither their birch and original; for whereas all domettick Bees, ar firt are imper a creatures, worms fixed to sheir Cells, wanting many fentes for 
ewenty dayes together, and ehen that they may live a more perfect lite after a death of twenty dayes, more tranfmuting beir Thape, come forth winged creatures; The Queen Bee is bred (as I formerly hinted) in another fathion.

There bee in cyery Hive ordinarily on the outfides of the combs (yet fometimes in the middle) but not near the verge?, litsle concaye cells (but one in a place) almolt like acom cups, bus no:hing near fo broad, yes fomewhat decper, very firc rg ard thick of wax, orbicular, wherein the Queen Bee injeds a ipermatical fubftance shick like cream, but fomewhas more yellow, wherein the Queen Bee is bred perfeet ar frift in all the pares, and lying almos round in it, feeds of it, and fo grows as the cbicken in the Chell, finft of the white, and then of the yoly (while the Hen fies upon it) uncill it bee difclofed.

The Asbenians banioned Pifiltretus from their Ciry; and the Syracufases Dioxifius from his Royalty ; and many other people fereral Tyrants for their want of hamenity and moderation: But in the Bees Commonwealth, never any Commander gave occafion of diflife to the Commons. Shee orders others what to do tor the publick good, or rather nature directs chem; Thee is provided for, and maintained by sheir labour, and shey directed, protected, and preferved by her fociety.

How the Queen Ere governs, I will not (as many conjedure) cannot cersasnly decermire; each Bee readily fulfills, and follows her proper task, and all in all, aim at the publick welfare; nere, how old foever, defring a Writ of Eafe, but all labour waill their labours kill them.

The Queen Beel-ves not retired (contrantly) in any part, but as occalionferves, is fomesimes in one part of the Hive, fonetimes in another, but works not, nature denying ter fitting organs.

And becaufe fome have obferved large orbicular cells on the edges (for the moft part) of the combs, shey have therefore fuppored them to bee their pallaces, but they are fearce capable of thalf their grown bodies, and are oncly femiraries for generation, not places or pallaces for babitation. 


\section{Thearre of Tolitical Flying Inferens.}

\section{CHAP. IX, \\ Of the Drone.}

7 He Drone is a great Bee withour a fting, the Vulgar opinion is, that hee is made of a Honey Bee that hath lon ber fting; but no man ever faw that a Bee became a Drone.

Others feeing the fondners of this opinion, have thought J.Stobreus de that the Drone is a different fpecies, and that as Bees breed potentibus fer. Bees, fo Drones breed Drones, which coriceit, if the Author 48. had oblerved, chat as the sime of their breeting, and many months before, there is not a Drone left alive to breed them, hee would have liked as well as the former.

Arifotle laith. Thas they onely are bred of the Bees, but the truth is, they are of the fame (pecies with the Honey Bee, but of a differeot fex.

Many reafons are laid dowa by Mr.Butler to prove the Mr.Butlox Drone to be the male.

Firft, becaur though they bee greas Mafters of che Honey, narch.c.4. Jet untill the Bees begin to leave breeding, and have conceived for the next year ( which Some do in $7 u l$, moft before Akgaft is expired) they (uffer th: $m$, afterwards they begin to beat them away, which if fome ftalls do not, they dye aaturally before Oalober; and from thenceforth all the Winter uarill the Bees breed agatn, there is not a Dione to bee found in rerkm narkra: When they are quite gone, then do the Bees lay no more feeds that year, but onely hatch and breed up thofe that ate in the cells.

Secondly, becaure as the rather, and the more the Diones are, the greaser and the earlier are ihe iwarms: So where the Drones are few and late, there is fmall increafe. And therefore if you kill the Drones of a Hive before they have done Cwarming and breeding (as fome fondly have dune before Midfurmmer, co fave sheir honey) neither will the fwarms cume forth that were formerly bred, nor the fock thenceforth breedd any more. Afrer which time bringing in Bee-bread 25 much as before, and having no young ones to (pend part, they lay ir. up careledy in their cells, where it corruptech and turneth to ftunking, 
fiopping, which will caufe them fo much to miflike their Hive, that in Autumn they will yeeld to the robbers. And if by your care and watchiulnefs they bee then preferved, in February following, when the breeding time begins, finding their wombs barren, and therefore loathing themfelves, they yeeld the ir goods to them shat will take it, and after a while by converfing with the Arange Bees, like of their company, and go away with them to the ir Dioner. But every fair day they will with them retuin to fetch that they left behinde.

Thirdly, becaure every living thing doth breed male and female of his kinde, and experience doth teach us, that the Bees do yearly breed as well Drones as honey Bees; and fee. ing the honey Bees are females, it followeth neceffarily, that the Drones are the males of the fame kinde: And therefore the Drone in the learned languages hath his mafculine appella. tion, as the honey Bee her feminine.

Fourthly, wee fee the like in the likeft Infects, the Wafps, Hornets, and Humbli-Bees, of which in their proper places.

Fifthly, I adde the Drones are males, and the honey Bees Arift,de bilit, Anim.lib. 4. crp. !. 1. emales, becaufe of the fmalnefs of their voyce, which is alwa: :s fmaller, and thriller in females than males, except Cows: shich bollow lowder than Bulis.

Wher the old Bees have ended their firtt brood of females, then laft of all after the fame manner, firt in the Drone comber whicit is one, and but one in every Hive, and almott the Pino Swat but backwadeft, made with deeper and wider cells for the nonce, "I cag 1t, they breed the male Bees, or Drones, as was long firce obferped.

In the later part of the ycar they breed fome promifcuzufly with the Nymphs, but sben they elevate their coyers,

That not many are bred before Mid-May, not any before. Mid-April (except a few by chance which are nor fuffered to live) as Atr. Butler afferts, is not fo; for there are. fome in all fwarms, and fome ftocks (with us) fvarm by Mid-April, therefore muft the breeding of many of the Drones bee then finilhed.

And after a Hive hath fwarmed, though before you faw not. 


\section{A Theatre of Political Flying Infecis.}

one fir, yet then fhall you take notice of their flying abroad every day about noon. But when the Hives are full, and yer fwarm not fo early as their fellows, they will then (but not often untill Mid-May) flye forth, and play a while, and then recura inco the Hive to fill their bellies.

Bu: to put all out of doubi, that the Drones are males, I adde that the Dione in diffection hath two large tefticles, greater, proportionably to his body than any other creature.

They are joyned together upward, but hang down towards the tail in two vilible parts, of a whitith watry colour towards the ends, their ends or points are of the bignels of a fmall pins head, milk-whice; the tefticles are half as long as the nether part of the Drones body.

In the belly is a white entral longer when it is extended then the whole body. They have lungs (if my eyes deceive mee not) of a reddith colour, divided as it were in the middle. The outward part of the back and brealt is of a grinly fubltance, under which is a kinde of Alelh, all of a reddifh colour, where is the hea", and other neceffary parts, although (wirhout a magnifying olafs, by an expert Anatomilt) not exactly to bee diAtinguifhed.

The eye hath a watry fubftance, and there is a vifible brain in the head, of a reddifh colour.

In the tail (which I had almolt forgot, though often made trial of it ) upon a little preffing, a faffron-coloured Ox-head, with ftretched out harns, and a crooked fnout will difcover it felf, which one (cited by Aldrovandus) preffing a Dione to experiment whether it had a fing, reports as a Arange, and never Gome
before heard of relation (I often faw it before I read him, or Maled any other.) And hee concludes that. nature in this portent doth thew the feminal reafon of them, and how being loft they may bee recovered 3 which how to effeet, Virgil and others have at Mr Remnant large difcourfed. This is fuppofed to bee the inftument of generation.

The tefticles are.in the upper: parc of the belly, and fo like- lib.4 cap 4. wile the males among burds have the refticles drawn inwards.

L.Verul. Silya

The differense berween male and female, in fome crearures is not to bee difcerned, otherwife than in the parts of generation,

Sil.cent.g. 
as in Horfer and Mares; bur fome differ in magnieude, and thas diverlly, for in mott che male is the greater; the chief caufe is, for tha. the maics have more Atrengeth of heat than the females; now heat cauferh grearnels of growch generally, where there is muilture enough to work upon: Bus if there bee found in any creature (which is rarely feen) an over great hear in proportion to the moilture in them, the female is the greater, as in Hawkes. Heat allo dilatech the pipes aad organs which caufect che deepoets of the voyce.

Ariftotle delivers that the Drones are bred by themfelves if the Commander lives, but if thee dyes, they are produced in the Bees cells by the Bees, and thefe fo bred, are more bardy and couragious than the other; but the trath is (as I binted before) all Drones are bred by the Bees, when they are wearied, and almoft fpent with breeding of females, that by thern they may have a new prolifical power whereby they may breed fermales afrelh; but the Drones are filt bred in the Drone combe, which is afterwards at leaft a great part of it filled with boney; and then is the latter part of the Summer, they breed fome Cephens among the Ny mphs.

As Ariftotle could not decermine about the breeding of the A rift.de bit. Drones, fo neisher of the making of the Drone-comb, fome. 40. times hee layes it down, yet as the judgement of others (ful(pending his own, as in thing uncertain and dubious) that the made their own combs in the Hive, or did sffit at leatt the Bees in that labour; fomerimes thas the Bees made the Dronecornbs, but yet onely then, when there was great expectarion of much honey; whereas in a Hive tored with Bees, there are not many dayes difference between she beginnirg of their own combs, ard the Drone-comb. Nay they begin the Drone comb and hall finith ir, before they make the Nurfiric (for fo I racher call them, than with Ariftutle, houfes or pailaces) for their Zueen, of which there bee alwayes fome in every hive. And therefore Ariftorie was deceivcd, who faith, They made the Queens Pallaces or Nurferies onely, Cwas fet um largior \& $\int e t_{3}$ when they had a numerous iffue.

The Beesnever deftroy the Drone-combesas Ariftotle affirms, althcugh they oo the Drones, when they have no more aced of them for ehac year. 


\section{A Theatre of Political Flying Infeits.}

Ariftetle faith, The Diones are ufeful, if not too numerous, and the Bees becaufe of them more induftrious, but wherein they are ufeful hee mentions not. Nay, hee allows the Drones no fervice in the hive; but by his leave they are profitable to the well-being and generation of the reft, being the males; and alfo by their heat in hatching the young, elpecially after the ftock hath caft a fwarm or more, there being few Beesleft, and molt of them in the day time abroad at their work.

But the Drone works not at all, as Mr. Muffet affirms, who MroMuffer faith, they gather wax, and fomerimes build the combs; but Tbeatrum Inhad heeferioufly viewed them, hee fhould have feen a difa- fector. bility to gather, nature having denied then fitring langs and tongue, for they are very fhort, and not fitting to gather.

A lian tells 2: long ftory, how shat the Drones lye hid among the combs in the day, but in the night when the Bees are anteep, rob and purloyn the honey, which when the Bees underftand (for moft of them fleep being weary with working, and a few onely watch) they firf correct them gently, and drag them out of the Hives by the wings. But for all that they will nor bee amended (for by nature they are gluttonous, and lazie) as foon therefore as they are gone abroad to work, they follow their work, namely fill thenfelves with honey; but when the Bees return and finde the fpoyl, thiy deal no more gently with them, but kill them out right.

Once the Drones do not only. Serve for generation (as hath been thewed) but do alfo much help the females by realon of Plin. Nat.hift. their great heat in hatching their broods. And for thefe caules l.18.6 11. they are alwayes in breeding-time mingled with then throughour the Hive : Although atterwards (when they have bien much bearen, and can go no where fingle, but one or other will bee on their jacks) they gather all together in a clufter for their fafery in orie fide of the Hive; fo that it is true at fometime, Aritt de hift: which the Philofopher fpake indefinitely, Teneri aivei losum pe- Animal.I.9. nitiorcm. And yet their hanging eogether will not ferve their ca 40 . turn, for the Bees, when they are difpofed, will quickly make them pare, and depart, when there is no ufe of them, there will Mr.Butier. bee no room for them.

The Bees breeding, or laying of feeds, beginniog to ceale in 


\section{A Theatre of Political Flying InJeCts.}

Come fooner, in fomelater; and thefe Amazorian Dames having conceived for the next year, begin to wax weary of their mates, and to like their room better than their company. Is feems incred ble to fome, that the honey Bees fhould receive a prolifical vertse from the Drones, which they thould exercife eight monchs after, and yet they confider not, that if a Hier. Fabricius Hen be trodden a day or two, forme afirm the eggs will be proab aqua pendence de tore matione ovi \& pulli.

lifical the year following. And Dr. Hirvey atcefts the fame; buc yet upon the experience onely of twenty dayes, ie is confeffed, that it is fufficient for that latter; and Arifotle faith, That generous Hens will lay fixty eogs, before they fit, others more; Co that they will bee fometimes prolifical two or three months, but afterwards they mutt bee trodden again, or the eggs will bee addle. But to leave this untill wree treat of Walps, when wee Phall bave a more fit occafion to handle it,

The Bees having conceived, begin to neglee, nay to molelt their Mates : At hrft not quite forgeteing their old familiarity, they gearly give them Tom Drums entertainment; they thas will not cake that for 2 warning, but prefume to force in again among them, are more Chrewdly handled. You may fometimes lee a handful or two before a hive, whicb they had killed within, but the greateft part flyeth away, and djeth abroad.

They are but thort lived creatures did they live their utmolt date; for eacing much, and being idle, onely in the heat of the day, with a great humming found, they flye forth, and ferching a Mort compais or two, having emptied themfelves, and wherced their Atomachs, they return to feed, and c hat alwayes of the pureft honey, whereby they ma ybecome fo foggy, that oft times before the Bees meddle with them, you may fee hundreds in a day crawl ra:her than flye out of the Hive, bur not able to recover the ftool again, mifcarry abroad.

And whereas poor ftocks (I mean luch as have few Bees, though otherwife well provided) delpairing of their own concinuance, ler the Drones alone, not difurbing, much lefs killing of them, yet noc one will our-live Oabber.

Bedx axiom. Some may ask, Is not the male more worthy shan the female? How is it then, that the Drones are buc vaffals to the honey Bes? which as they excell the Drones in vertue and good- 


\section{$A$ Theatre of political Flying Infects.}

goodnefs, fo in power and authority, ruling, and over-ruling them at their pleafures. Albeit generally among all creatures, the males as moft worthy, do malter the fermales.

And this Sefoffrot us King of Egypt, who conquered a great Ceelii Calcag. part of the world did thus exprefs according to Herodotus. If Commented hee overcame any people without contention, or battel, hee verbcrum 2 made them beas the badge of 2 woman engraven in their weapons, bur if they did fight it out cour agiouny, the cognizance of cato a man. Yer in thefe, and a few others, the females have the preheminence: And by the Grammarians leave, the Feminine gender is here more worthy than the Mafculine. Ss in all the kindes of Haw'ss, the female doth command the male, as being the ftronger, and the better armed. And the femais of the Bear, and the Panthar are more bold and couragious, ftronger, Arift de hillol. and of greacer Cpiriss.

The female Ounce likewife, though lefo than the male, yee is Jo.Caii hir. more cruel.

Ridiculous is the conceit of Demoeritus to catch the Diones. Wet, raith hee, the covers of the Hive with water, and in the rarior Animal. Weeker.de Cecrer.1.8. morning you thall finde the Drones bufie fucking thereof, for feeding of the belt honey, they are al wayes thirlty; Nay becaufe they feed of the belt honey, and noe Sand aracbs wbich is horter, they are not thirfly ; for the Bees all Winter long, while they live, thereof drink not at allo

Timely ridding of the Drores by the Bees, is a good figne that they are like to bee forward the nex: year ; becaule the Etocks that have caft ofren, do bear long with sheir Drones, atshough there bee twice fo many as bee needfal for the Bees, shat are teft, therefore ( to fave the honey which thefe would devour) it is not amifs to prevent them; and about a fortnight afser their laft fwarm to diminith their numbers, which you may do fafely in the heac of the day, killing them with your fingers : And the bruifing of them with your fingers before the Hives moush, will fomecimes caufe the females to take the worke out of your hand, and fall upon them themfelves.

Some ufe Drone-pots made of Oziers, the twigs being fet So clofe, that the Drones, although they go forth, yet cannot cafily return in again. But the carching this way doth much 
trouble; the Bees may fometimes keep out the Queen. And sherefore I like not of them.

\section{CHAP.X. \\ Of the Generation of Becs.}

T hath been an anciene tradition, that Bees have a ewofold 1 produstion, ss many other creatures, by generation and putrefaction. About this latter way, Virgil, Cardan. Alurovandre, and many others have been copious; but whether there bee any folidity in this particular, I am fomewhat dubious, becaufe it was never authentically proved to bee performed by any. But they tell us that the beft fort is procreated of a corrupsed Lion; And therefore fay it is no wonder, that being fo fmall creatures'they fearnot any, nay pievail over the grearelt, with 2 Lion. like courage affaulting them.

A fecond fort is bred of a Bull, and therefore they are called Suide Hito- the daughters of Bulls, becaufe they are bred of their carrick. kaffes.

A third fort of a Cow.

A fourth fort of a Calf, but tell us not wherein thefe kindes differ, for they forgot waking what they dreamed of fleeping:

Would I fpend words to no purpole, I mighteafily for the general, evrce the invaiidity of this opinion, for in Brafile, $P_{k r} u_{3}$ and miclt is? the new world where are many foris of Bees, and fome in colcur and magnitude not d ffering from ours, there were no fuch creatures, where of (if they were loft) they might bee a oain recciered, before they were tranfported by the Spaniards.

But more abfurd is that opinion of others, that of the afhes

Wustet Theatrum Infector of Bees bedewed vith fweet wire, and expofed to the Sun in 2 warm place, thers will bee a prefent refurrecion of the former buin: Bees。

Dr. Elarey de Perpleied and various are the opinions of the Learned, cono generato

Aninaloex. escifat. I $3^{\circ}$ cerning the genesation of Bees.

The firtt workings of nature are as dark as midnight, and with 


\section{A Theatre of Tolitical Flying infeds.}

with their fubslery do nor lefs be-fool, and deceive the ftrongef underttanding than the boduly eye.

Some not comprehending their conseption and generation, have fondly delivered that they carried the fpermatical matier of their original into their hives, gathered out of flowere, and after hatch them, escher from the white toney fuckle, or the reed' or $A_{1}$ iff. de hift. Calamus) or from the Olive becaule, in yeers a bounding with $1.5 .6 .1 \mathrm{~g}$.

Olives, there are plen'y of fwarms. Not confidering that the firtt brood is harched before any of thefe flowers bl flome, and that fome of thefe flowers are not at all in the Northern Regions where is the grea elt plenty of Bees.

And for the O'lve, Pliny denies that they tafte of it, and $P^{\prime}$ in, Narohift. therefore faith, ir is berter away; and yer hee was fomerime of a lib. 2 I c.I 2. contrary opinion.

Cardan denies that they lay eggs, bue are bred of honey. idem.lib.ir. caf.8. This Scaligtr well oppolech, becaufe, faith bee, There canbee l.1. no generation of honey, for then it thould bee the feed of the Scalig de fub. Bee; but this is falfe, neither of honey corrupted, for it $\cos ^{-}$til, I I I : $x \in \mathbf{r}$. rupts not, but preferves from purtefaction.

Scaliger queftioning whether Bees did copulate or not, faith chat of the dew inleaves of plants, worms are produced, and therefore dew opportinely gachered, and fomented with a genital heat of the Bee may be an'mated into a worm. But che firft, and chiefelt breeding of Bees is inche end of February, when they fcarce ftir forthat all, or not untill the dew be exhaled. And howfoever unill May, dews are known to have litcle efficacy, or excellency, befides you may vifibly fee the eggs when they are firtt injected into the cells, they are eggs, and not a dew.

$S_{\text {caliger, }}$ thoughtice propounded the formeropinion, yer held not to it; for whereas Aliffrtle delivers it as an opinion of fome that the Bees bred by copulation, and that the Drones were males, and the hon:y Bees femules; this faith hee is falle scalig Com. (although without reafon or experience)for the Bees indeed are ment in Arifo fermales, but the Kings are the males: And Muffet alfo ac- deh it. Arim. kracwledgets no males but the Kings.

1 beleeve, faith CHaffit, they propagate by copularion, and the greater are males (namely in his (enfe the Q:reens) and the Muffet in lefs females, bue whecher they rread as Cocks hee profeffeth that $1, x, 6.3$. he knew not. 
Michael Toxi:es in Onow maflice fuper Theophraft.

Mr Remnant hil, of Bees.

Arift de gene. lib. 3 . cap. 10.

Toxites fuppofech chat Becs copulate, and that the Bees are the Males, and the Kings Females : And that the Kings doar certain leafons caft forth worms in multicudes as flies, their flyeblotes,and that the Drones fit upon them, and hatch them after the manner of Serpents.

Another faith, the matrer in which chey blow or breed, is Something that they gather of the flowers or plants, and bring home, and pur inio the holes, or cells of the combes, which chey mix finely with a little water, and then blow in is a ching lefs then, or as litule as a fye-blote. Bur this cannor bec, for wee finde nothing in the cells wherein the feed is injected, but the feed it felfo. And again, the Bees feed is much bigger than a Hye-blote.

And as to ochers, fo to Ariftorle, the generation of Bees feemed very ambiguous and doubtul; for whereas among fílhes fome gensrace without coputation, he fometimes fuppoled the fame of Bees, and argues thus: They mult eisher ferch their young elfe- where, as. fome in his age opinionared, which young mut be either bred of themfelves, or be produced by fome other living creature, or they muft generate them, or partlyfetch them, and partly generate them: For fo fome fuppoled that they ferched onely the Drones, or elfe they muft generate them by copulation, or without copulation, Thus Bees by copulation among themfelves to breed Bees, Drones to breed Drones, and the Queens to breed Queens. Or all the reft from one kinde, either from the Queens, the Drones, or the. Bees ; for fome, he confeftech in tris rime, held that the Drones were males, and the Bees females : Orhers beld a contrary opinion, that the Bees were males, and the Drodes were females.

But againft all thefe tenets, Aviftolles seafons as impoffibilities. If faith he, they breed not, but feuch their young elfewhere, of neceftry it muft bee, that shere be Bees without any labour of Bees, namely in that place from whence they ferch their feed; for why do they,come to perfection, being carried away, and not in their own proper places.

Andagain he faith, It agrees-not wich realon that the Bees are females, and the Brones males, becaufe nature nerer gives femalss weapons to.defend themfelves withall. 


\section{A Theatre of Political Flying Infects.}

Now the Diones are weaponleís being withour Atings. And on the contrary, it is not reafonable to imagine that the Bees are males, and the Drones females; for no malesare diligent and laborious in educating of their young Cock-pidgeons, and mott males among birds, fies part of the day, 25 well as the female, and as diligently feed their young. Some fay the Partridge makes two nefts, and the Hen fxs upon one, and the D . Har.ezer. Cock upon another, but they are miftaken. The malcs alio citar. 38. of beafts of rapine feek out, and provide for their young.

And that fome Bees thould be males, fome females, is alsogecher likewife improbable, for in all crearures the male differs from the female, excernally many fowls differ not, as Crows, Rooks, and many fmall birds.

And that by generation they fhould procreate, is as unlikely, becaufe no man ever faw it.

At lat he determines that the Bees are females, bus as plants have both fexes, becaule the fex is not to be diftinguifhed. But if the Drones are bred without copularion, then also keeping the fame order, the Bees, and their Commanders, are bred without copulazion.

He concludes after a long uncerrain difcuffion of this doubr, That the Kings or Queens Bees breed themfelves, and the Bees. It is neceffary alfo that the Commanders be procreared by fome, but neither of the Bees, nor of the Drone?, therefore of themílves.

Now the Commanders cels being latt made, and but few in number, shey breed therefore their own kinde (few according ro the cels) and allo the Beer. And the Bees breed the Drones, and chey breed nothing; and to the Generation determines in the third number, Non tamser fatin. odhuc explerata que eveniant babemus; fo that in all this we have it confelt; there is much to little purpole: The Drones, whatfoever fome fay to the contrary, is the Mále-Bee, and although he be not feen to engender with the Hony-Bee, either abroad as other Infects do, or in the Hive, which (whatfoever fome have :projedted) is unpoffible, yet withour doubs is hee the Male- Bee, by whase natural heat, and malculine vertue, the Hong-Bee which breeds, both Hony-Bees and Drones conkeiveth; that they are Males, we haye fufficiensly proved in the former Chapter. 
Yothe next piace the main Quevy is, how the Bees receive a prolifical power from them.

Aibertus $M a g-\quad A l b$ :rius denies by eopulation; but granting the Drones to aus.1:6.25. be Males (which is undeniable) and the Hony-Bees Eemales. A iffotle concludes tor ir, he fatch, coeant ea in quibus mass it arit. de Hith. femina ef. Thofe creatures conceive by copulation where there c. 2 be Males and Females. And again; they that are bred of the fame fort, or kinde, if there be among them Male and Female, Idende Hilt e cottu generantur, are bred by copulation: And this is afferced animal. $l_{1}$ b. s. by o:hers.

c. r. Geor. pifcaco becaule there be but few young in their cels; but other Fofects
"'us. that are procreated by copularion ingender long, and hatch Aert, de Gine* quickly: This Reafon is frivolous, nay falle, for the Becs are rat. lio. 3. a 10 numerous in their young (that I lay not almolt innumerable) and they hatch quickly, fooner than the $W a f p$. And jet that Wafps are bred by Generation (being cognat srum generatio) and not Beer: He atrribures it to a defect of Natwres bounty towards them, becaufe nibil ut apam, bategt gerus divinitatis.

So that according to the Philofophers axiome, and the weaknefs of his realon to the contrary they do engender together; but becaule this is not vfible, and therefore perhaps may be denyed by fome cavilling Sceptick. I will further Mow that the Hony-Bee may have a Mafculine vertue from the Drone, otherwile than by copulation. For in the Eele, and the Purple, (a Shel fith whereof Puple comes) is no Sex vifibie, yee by their flaver, nor by copulacion, do they ploduce their yourg, and perpetuate their kinde.

And many other for:s of fithes do not by copulation become fiuiful, and generace their kinde; but when they have broughe forth, or laid ineir Egge, the Male bedews, or fprinkles them Arift, de Hint, with a feminal morture, whereby they are not addle but 38 prolifical.

D: Harvey de I ave leer, laich D: Harvey, the Male-Fithes to followgencrat. ani- the Females in thoals in breeding - time, that they might fpinkle mal. exercitat. their rew laid Eggs wich their Milt, or feed. Thus the Sepia or Cutrle-fin.

There is a Filh called Glanis, in the River Glanis in Hetru- 
ria: The Female whereof by rubbing her belly on the Males

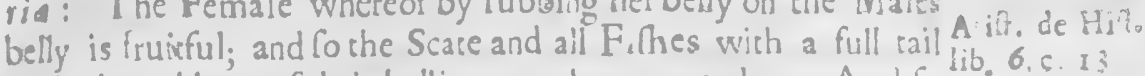
with the rubbing of their bellies together engender: And fo in a word do all fithes, befides broad griftly fifhes.

All Fißhes that bring forth Eggs, their copulation is fcarcely vifib'e, but without a Male they conceive not, nor any other Anibrofe hexCreature where there are Males. Vultures faith Ambrofe con- am I. s.c. 20 , eeive withou: a Male, and generate without conjunction; but Aldrevandus on good grounds denies this; and allo Albertus, ul yl Aldro. who laith, they are often leen to tread.

Oinirbolog.

When the Bees have conceived, they deliver their feed, not by their tail, but by their mouth, fatum edum ore editum ut Asint. de Hitt. aiunt quide $n$; and this was the caufe that fome thought that they an:ma 1.10 . 5 . ferchr it elfewhere from fome flowers: Ariporle therefore cory fpeaking of it, (peaks doubffully $\tilde{\omega} s \lambda \varepsilon y \delta s i v$, for it is a very obfcure thing.

And that they blow their feed, our Vulgar expreffion intimates, for their young is called fpar, that which the Bees fpit forth, or deliver by their mouthes.

If wee affirm the feed of the Bee to be blown, it cannot fo properly be called an Egge, Arifforle faith Aquopendens was ve- Aguapen. de ry careful not to cali the feed of Infeets Eggs, but Worms, yet formatione a Di. Harvey cites him, as if he fometimes or promifcuoufly, cal- vi \& Pulli. p. 1s led the Worms, Eggs; It is true, hee called the feed of a kinde Arift. de Hift. of Grahopper Eggs, but it was bef, re they were quicknid Dr. Har. de but when they aie harche, hee calls them no lorger Egggs, but generar, ani. worms: Although indeed they may feem when they have mal, exercitat done feeding, and are inclofed in their cafes to be amalogous 61 eggs, but not while they feed; and therefore Ariftorle faith, Arif.de generr Every kinde of worm when it hath attained his full end, and 1.b.3 c. p.9. perfeet magnitude, is as it were an egge, for the fhell hardens, and for a time it fitirs not, which, faith he, is apparent in the worms of Bees, Wa/ps, and Caterpiilars,

But the Philofopher enumeraced too faft : Of Caterpillars it is true, and of all others that have proper, or natural cafes, but fuch as have adventitious, as Bees, and Wafpes; never harden.

An egg properly is that, out of a part whereof a living creazure is produced 8 . and the refidue is mear for is, inproperly that 
Aqua pend. that is $2 \mathrm{n}$ egg our of the whole whereof, a living cereature is bred, as the eggs of Spiders, Ants, Flies.

A rilt,de gen. Infects firt breed a worm ( alchough it be not yet a worm lib. 2.c.i.

Mr. Butler, Mro untill it be hatched, but indeed rather an egg.) and this after a fpace of time is a kind of egg, for the Aurelia hath the faculty of an egg, and a living creacure is bred of it, receiving in the third nutrition, the end of generation.

Levit, Mro

Remnast.

That the Bees blow as a Flye cr Wafp, is affirmed by fome. And as the blotes of the flyes are nourithed by the fleth wherein they are blown, and by the earth wherein they are bred, fo the fpat or brood of the Rees, faith Mr. Levit, are nourithed by honey and warer; but of this in his place.

The Bees leed is white, about the bignels of a Butcerflies, not round, but oblong, which they lay clofe under the horeycombes. In the middle of the bottome of the roid cells Mr.Burler round like a ring, faith Mr.Butler, but although he was a great obferver, yee for want of obferving himfelf, and following, as he fuppofed Ariftotle, he was miftaken in Tbeod. Gozas iraniI.Gaza lacion, who renders the word, $\pi \lambda \alpha$ '́y lov by obliguzs, which Scaliger well reads ad latur.

The Bees reed firlt fticks to the fide of the cell, faith Ariforle, ad lar us jacet, alwayes (as I remember) at an angle, Arift de h.ft. fome diftance from the bottome, and fo doth the Wafp lay her Animal.1.5. c. ' 9 . feed, and not clofe to the bottome; thus it Aticks with one end, and with the other end bends Ilope- wife towards the middle of the cell.

And after it is hatched, it lyes a while crofs, or fide-wayes, with the mouth fomewhat erected, and grows fo long as the matter of augmentation continues, which is not long, and then it falls to the bottome, and raifeth it felf up that it may be fed. It will raife it felf up, and fink as it were within it felt by contraction when it pleafech; for though it have not feet, yet the skin is fomewhat fcabrous whereby it reuls, or moves ic felf higher, or lower within the cell.

The Bees in their breeding difeend by degrees towards the nether part of the combs, filling one cell aster another: But when their chief breeding is palt, they do not precifely obferve this order, but lay up their food promilcuoully among the young Bee?, where they find the cells empey. 
Firf, The feed fticks to an angle abuve the bottome, wien it is hatehed, it falls afier a litile lpace to the bottome, but canno: come furth to take food, which yet Arift otle feems to grant tobe neceflary: Firf, he laich, It is nourithed, bue cells not how: Secondly, he faith, over againt the cells, where the young are bred, the hony is.lsid up, he tells us not where. fore.

But Sintiger faith, That the y ung may eat thereof, ut Ac- Scalig.Comcumbenti cibus oppona:mr, fuppofing, as he profeffech, 2 few ment. in Aritt. words bstore that, the worms and hony were both together in de bill.1.5.c.s one cell, for he rationally concluded, chey could not live and grow without food, they were nor locmative, and therefore could nos ge forth of their cells for it. How therefore they mould receive it, wis the grea: myltery: He fuppofeth the worms to fticis faft on one fide of the cell, and the hony on the osher, that wich bowing of cheir bodies, they might feed themlelves. The worm, faith he, Aticks fo falt to the fide, as if the were glewed or rivited there, but by no means ac the bottome, left the fhould be drowned with the hony. And this fuppoficion of the worm and the hony baing together in the fam: cell, made him conceire the worm fraller than the Bee; for faith he of the feed is generated a worm, which worm is alwayes lef's than the Bee; but this is not fo, for the grown worm is every way as great, and as large as the B:e.

But neicher of the former opinions are trus ordinarily, for the Bees are bied ufually in the combs before, or in the lowee part of the other combs, the hony (if there be any) bsing repafised in the backward combs, and the upper parts of the other. It is true indeed, thatche Bee-bread is of laid up in the void cells, among the breeding cells; no: that the young may feed themfelves, but shat therewith being ready, and near at hand they may befed by the Bees.

The feed is never vifible in B:e or Wafp, that I could difcern upon diffections of many in one part or o:her.

Cordan affirms that they cannor have egos witbin them, and be exercifed in their continual lab ours, becaufe neicher S.lkCardan. de cubtil.t. I I, worm, nor Grahopper as long as they flye, have none; fuppofe the affertion true, that they have not eggs within them (bus blow sheirfeed which I beleere) yes is this inftance and 
reafon very weak. Scaliger anfwering him, juftly denies what he faith, but contradicts not his infance, onely faying, That they that are well verfed in natures fecrets can determine this; whereas it is well known, that the Silk-worms when they have wound up themfelves into their bottomes after twelve or fourteen dayes eat themiclves ou: a winged creature, but have litele luft to flye prefently for fulfilling their lutt, and ergendring together: Whereby the male having (pent himfelf falls down, and dies, and the female alio as foon as the hath laid her eggs. which is not long after.

As for the Grahopp:rs, they will flye nimbly with eighty, nay one hundred eggs in them as big as the eggo of Pilmires, and the claw-taled Humble-Bee (of which afterwards) works as diligently, and flyes as deliverly when the is greas with young, 25 when the is barren.

Fabric ab Aquipind. Exer.

Scaligar de fuscil. exer, 331.

Fabricius concurs with Cardan, and therefore senders this as a reafon why fome creatures lay eggs, and bring not forth living creacuies, becaule if they were detained in their bodies unill they were hatched, with their weight they vould hinder their flying: It is true, if many were animated within them at once, it might be lo, otherwife not, as is manifett by the former example.

And that it is poftible for Bees ro lye with eggs, Scaliger makes good by thefe following inftances: Hee took a Glowworm engendering with a female, and put them all night into a b.sx with a hole in it. The ma'e continued at his work next $\mathrm{d} a y$, and at noon giving over, $c y=s$; from that hour untillevening. the female laid many eggs which were hatched in tweniy hours, and prefently went their way; fo that fome Infeets ipeedily husch, and perfect their eggs.

Therefore he conciudes Bees may copulate in a few hours, and prefently lay their eggs.

Likewile he relates, tha: when he was a fripling, that he sook of the greater fort of Ales, one masked with whice Arakes, and holding it fome while in the hollow of his hard, being delighted with the hape, it brought forth many white worms nocable for their motion. And therefore as thee carried worms, fo may Bees eggis when they Aye.

Buti she Fielh. Alye, Butier-Alye, and many other Infects with- 


\section{A Thearre of Political Flying infects.}

without all controverfe flye about with their eggs in them. Now Scaliger at laft difcovered his little experience in the nature of Bees, when etinking to anfwer more fully, hee mars all: For whereas $C_{2}$ rdan faith truly, they are in continual labour, hee denies it, andaffirms, that the Bees bavirg gotten honey by labour, they take the benefit of it without any more working: Whrteas in is certain, that they never give over working (the feafon being firting) as long as there is any thing to gather, and they give over breeding, before they give over working.

The feed being hatched lives, and excerns excrements. Al! Infects firt make a worm, excep: a certain fort of Butter-flye, which produceth a certain hard thing, like wilde-faffron feed, bu: Aluid within.

Now the generation of Infecis in thefe worms, is not caufed in fome part onely, as that fome part of the egg, curns to the formation, the reft to the nourifhment, bat the whole alters uncill it attain the juft and due proportion.

Crearures which produce a worm firt, bring forth a fmall one, which is increafed by it felf, without any addition, as meal by leaven is made of a litele mafs a greater.

And again, fome creatures have this property in themfelves, that they have an increafe for themfelves, as the worms of Bees, others Arift. de gene: 52t.h.j.c. 4 . Id $\mathrm{m}$ de gens. rat.l.3. 9. gacher it abroad, as the worms of Butterfles, calied Ca erpillars.

This is, if at all, but partly true; for after they are hitched, there is a fmall augmentation from the feminal vertue; but as foon as they are capable of food, they mult have it, or elfe afeer three or four dayes they will dye, as I have often exper:mented; whereas when they have done feeding, and are thut up with their waxen covers, they will (though out of the Hive) live, and come to perfection, but will bee perhaps longer in their Metamorphofis, than if the were continued in it. I have had fome three weeks before they have eaten themlelves our.

Creatures thaped without she females womb have in the egge, as well matcer of $n$ urifhment as matter of generacion of the bocy, bersufe afier the eug is $]$ id, and livered from the body (of the 'ien. or other creature) it hath no more nourithraene $\mathrm{km}$ n. Heil, but nnely a quictin no heat when thee fits, but as toon as the chicsen is diticloed, there is not much 
longer ary matter of nourifhront, but it muft receive is eliew where.

Ariftolle acknowledgeth that they voidexerements, and can there bee excrements without a fupply of food, or a mutiplication of a little feed acove a hundred fold by the ieminal vertue, or ambient aire, efpecially where the excrement are four cimes fo much as the feed, or egge was at the beginning ; yet Aldrevandws concurs with A rifictle, fayirg, That the worms of Bees and Wafps have within them that which is the matter of their augmentation; the contrary whereot is evidene, for if the Hives be not prcvided before hand, or fupplied daily with food in formy and unfeafonable weather, the young brood will dye in the celis, and you may fee the old ones catry them out in abundance upon the fir it change of the weather, and then breed agaipo.

Ofien towards the end of Summer, if hony-gathering bee not plentilul, they will draw out the young unfledge Cepberss. and forresimes (chough rarely) the Nymphs, lett for want of furficient meat they thould all ttarve together.

Finhes produced of eggs (as almolt all are) either within. the females, or withoue them, at firt receive no mear, fed crefcurt bauffo cvi bumore, but afterwards are nouribed when they grcw wish the river water.

Dr. Har, de gen.animal. exer.44.

Harvey de genoexer.52,

Idem exercio 2a?.9.

Idem exer, 6 :
In the generation of Animals which are procreated by an afo ter additioo of pares (as the chicken in the egge) there is not to bee fought another maiter, out of which that which is to bee produced, is to receive the fape of a bedy, and another out of which it is made, noulined, and increafed. Eut here in the egrs of Infects, it is otherwife, becaufe they are not at firt perfeet, and therefore mutt have an increare, and augmentarion elle. where, antill the $y$. as:ain their jut magnieude.

The eggs or wo ms of Infects have from withour ithem that whereby they ircreafe. But how the g have it ${ }_{2}$ sa riddle. seeds. of teibs, as Beans, or. aitraa by their hasks, or Thells the moifture of the ground, whicb they fuck in tike fpunges, and are therewith nouriohed as well as if they received thellame by reines. But thus the.worms in the combs cannot beefed, the meat being remore from the m.

Titer Bes romic forth the honey which they have gathered 


\section{A Theatre of Political Flying In fects.}

and digefted in their bellies, and lay it up in their Hives, and after the fame fort the Hornets, and the Walps nourilh their young. The affertion is not true, or very ambiguous and imperfeet. If hee underftands that the Hornets and $W$ afps empry into their cells what they collea, and gathe'r, then is it nos true, for they lay up nothirg that ever l could finde. If it bee underftood that they feed their young with whar they garther, as alfo the Bees, with what they gather, and a!fo with that which they have formerly injected into their combs, when the weather will not permit them to gather abroad; than it is a truth, but darkly, and imperfecly delivered:

So then wee fee after that they are difcloled, they mult have meat; out of their cells they cannot come, nor creep, they are not locemative, like Caterpill ers.

Now the main Query is, how they Phould have it? And the ignorance of this caured Arifotle, and others to deny, that they received any, fo that from the hiltory of their being a worm, to their metamorphofis ineo a Bee, wee hear of nothing.

Concerning this, I was long withour facisfaction, and finding that it was impoffible to obferve the particulars among the Bees, becaufe of their numbers and clofeneis, I lought to find'e it out by oblervation in other Infects of fome whas differing, yee of a like nature, in many particulars. I confidered that yearly in my empty Hives shere bred Horners, I took notice tberefore daily of the progrefs and order of their work, and generation; which I found to bee thus :

The Hornets nealt is begun by one morher, or breeding hornet at the firt, which in the top of an empty hive wrought a. very fhore little droffie pendant peg or pin, about the bignefs of the tag of a point of the outer dry parings of pales, or other old timber wich a mixture of a gummy liquor that flows from oaks principally (of which matter are all her combs framed) this thort peg thee made the foundation and center of a Canopy, or Tent like to a balf globe, in the center of which with in, the worketh fix or fever hexangle cells, all concurring and meecing together.jis the center, bur all jucting out on each hide downward, and having wrought them half their depth to an angle of every cell fomewhat above the hottome, thee injecteth into each a leveralieed, and then on the out-fide of thofe 
sells begins lix, or leven more, but all cocentring in the fome point with the former; and when they are wrought half their depib, fhee injecterb into each a particular ieed; but before this is done and finthed, thee quickens and hatcherh the former, encompaffing with her body, or lying round like a ring abcur the pin that is the center of the globous depending Tene, or Canopy, but in the infide of it, that her heat may equally tranfinic ie felf to each cell, and enliven every feed.

Within a few dayes thus receive they life, and beg $n$ to fir, at firt fticking at the taile end, and then falling to the bottome, do they raile themfelves upward. Now the mother fomecimes lits upon, or rather abour them, and the laster brood alio to ha:ch and comfort them, and iometimes gees abroad and fetch. eth food for them, and giveth it them as a bird her young, with her mouth going from one to another : And as they grow thee worketh the ceils deeper, unull they artain their perfeet growth, which will bee above three weeks, and then rhe firt brood begin to bee corpid and dull, and receive no more foud, which when they refure, fhee worketh a cover over them, whiter than the co nbs, and they fo continue thut up about three weeks, and being tranichanged from a worm co a Hornet, eat of the cover, and come forth, and work, and breed their kinde, but chen being many, in broad combs.

And as they are fed, fo al $\mathrm{Col}$ am confident are the Bees, atthough shey come to their perfection in a fhoreer fpace : For chey allio afier they have fed abous eighteen dayes, and attained their grow: h, are fout up by the Bees, with a waxen cover, and conrinue fo abouc the like fpace wherein shey are metamorphofed, and eacity the cover bifore them, life up the reft with their head, and come forth winged creatures.

Of this metamorphofis of Infects, Arifolle chus; Every Arit.degen. impetfect conception producesh firt a worm, which is afterAnimal.l.3.c.s wards perfacd by a change and metamorphefis, and becomes a living creature.

Do Harves de In the generacion of Animais formed and transfigured of a generar. Anim. matser piepared and provided before-hand, and all the parts æxercira.44. begin to appear, and are diftingu:thed together by a irea$\because 6$ morphofis, and a perfect creature is broughts forth: Lü f rme, ore part or member being made before anotner of the 
fame matter, afterwards are rogether nourithed, augmented, and formed.

The frame of thofe begins from fome one part as the original, and by the help thereof, the other members are added and joyned rogecher; and thefe wee fay are done by a Epigene is, or afier addition of parts, namely, by degrees, part afte: part, and in refpect of the other, properly is called geueration.

Afier the firt fort is the generation of Infects, where the worm by a metamorphofis is bred ot an egge, or the beginn ngg are procreated of a corrupting marter (the moif dsying, or the dry moiftening) of which as of a Caterpillas grown to a perfect magnitude, by a metamorphofis a Butterflye appears in the juft magnitude. Give mec leave to vary from lo learned ar Aushor, and diligen: obferver.

It is a truth that there is no metamorphifed creacure, and addition of a new macter or magnitude, yet in many there is a diminution for thole that have not adventitious cales, or covers, as Bees, Horners, and Wafps, but natural hardened theils or covers, as Caterpillars, \&c. have fo much (as the fhells or covers ) fubtracted from the being and fubltance of the future Butcerflyes.

And this allo holds noe that all the parts b:gin to appear,and are diftinguithed together for the change and metamorphofrs of Inleets is not altogether, bur by degrees, part after part is changed, and alcered, as wee will further make appear in the particulars.

The alteration of Infects in fume is made of the whole, as Bees, they having no membranous stins or thells about them, but the cells of the combs, and not of any parts of it: But every fuch kinde of worm, when it hath accomplifhed his magnitude and greatnefs, is made as it were an egg, for the skin hardens, and all that time it is immovable from its place, yec móves in its skin. cell, or Thell, as is vifibly evident, for touch the out-fide and they will contract, and Air.

Now the caule hereof is, becaufe nature haftens, and before it bee a perfect egg, brings forth fo, that the worm by degrees, grows to the bignefs of a foft egg, and after in feafon, eats through the cover or thell (for they are not repotited in cells 
Arift de gen. as Bees) and comes forth as a chicken out of an egg being perlib. 3.cap s.

fected in the third generation.

Their metamorpholis is their Miz aldus me perfection, and yet fome groundle fly have delivered the conmorsbil. cen.s. trary. Wonderful, faith one, are the mecamorpholes of fome 60.

Mr.B.:Ber Feminine Mon.c.4. creatures, for Caterpillars getting wiings degenerate into a Butrerflye.

The worm being now dead, prefentiy the alteration bigins from a worm to a Bee which is twofold in Mape, and in colour. The firt alteration in Thape is the divifion in the middle; then the other divifion betwien the head and Moulders, Thus Mr. Bull.r. Bue it is otherwile, for the tranfmutation as in a Wafp, begins to be firt vifible in the fuperiour part, and the eyes are firlt difcerned, and then the incifion between the head and the Moulders, which yet as it grows more pe:feit, becomes fma'ler, the middle incifion or divifon is fcarcely vifibie, when the eyes may bee feen, then the legs, and the horns begin to bee framed, and the wings are laft fininhed.

When they are perfect they thrult up the covers over their heads, which hang at their backs till they come forth, their fangs and tongue hang down on their breaft, but whin they are come forth, they then contrast them (untill they have occafion of their ufe) and draw them up clofe bending under their throats, that they are fearcely vifible, but when they eat or work; their colour is at the firf afh colour, and fo are their wings, but in a lictle fpace they convert to a dark brown unsill they grow old, when they become gray.

Arif.de bift. And thus it is in many other creatures. Fifhes procreated of 1.6.6\% eggs, have their eyes apparently great, and oblong, contrary to thofe creatures which are bred of worans, where the head and eyes are laft. But hee was deceived, for io the metamorphofis of flying Infeets, the alteration begins at the head, and is fult vifible in the eyes.

As in dry wea:her Bees gather moft honey, fuppore it with moderation, for immoderate drought (as in the year 1652.) withers away the Alowers; fo moift weather produceth ftore of Bees, fuppofe it ftill with moderation, for otherwife (as in the year 1.648.) the perpetual raines walhed away all the lubftance of the llowers, that not onely the fwarms, but old Atocks genesally dyed.I loft above half a hundred, 2648 . for my fhare. 
Now the reafon why moit weather produceth tore of Becs, is becaure the Bees do fpat and treed the falter, and preferve and nouril $\mathrm{h}$ their brood the better by the moifture that fallesh in thofe times, which in dry weather they cannot fo well get, or rather approve noc fo well of, for afser a warm rain, you may fee them drinking on every herb, you can hardly fes your foot on the ground or grals near the Hives, bue you mutt tread on ehem, and that when their water is jult by.

Too much fair weather is deftructive to the increafe of Bees, for going forth every day to gather, they are therewith wearied, and neglect breedirg, and fo chough they leave fat falls, ye: in 2 Thorteime few : $\mathrm{H}:$ ves, and therefore Columella advifech to Colum lib.g. fop them in, every shird day, that they may atrend to breeding.

The Bess breed beft, faith Arifosls, when they gather molt honey, but herein hee was deceived, for they gather mclt honey, according to his own poftuon when she honey $c_{0} 19$.

Aritot.de hil. Animal.l. j. dews fall, which faith hee, is not anse vergiliarum ortum. But wee have often fwarms, a firt, and a fecond allo out of the fame Hive before that time : And generally all good $H_{i v e s}$ are well furnithed with young before that cims of the year. Indeed hony is not the ordinary food for the Nymphs, but Beebread, which from Mid-March, and in fome temperate Springs from Mid. February, they plentifully gather.

\section{CHAP. XT. \\ Of the Hives, and ordering tbem.}

Jow having at latt, though noe without erouble and travel delivered our Bees, and broughe them in:o the world, it is high time to provide them a houfe, and a fitting Atation, which when I have done, with as much brevity as may bee : I will enterrain the Reader for his pains, and patience with a collation of fweet meats.

They have Hives of feveral Thapes and mateer, in feveral, and divers Councries, fome of Ozier, foms of Barks, fome of Petrus Cier. Trees hollowed (and this fort the Amtricans about $M$ xico cen: lib. 9. ufe) fome of (quare boards, three foot high, and a foor broad; c. os. 
fo in farcity of Hives, I have known fome ufe Butrer-fiskirge? Some of easth, which they daub with Cow-dung within, and without, becaule the incotl nels is effenlive, and the heat and cold allo orherwife wouid bee too extream.

Plin.hi?. 1.21. Pliny faith, The bett Hiver are made of batks of trees; a c. 34 . fecond iort of Rods, and a third fort of Wick ers.

Each Country almolt hath his feversl tafhion, as well for the matter whercof they ate made, as allofor the manner and form of their making. In our Councry, the Hives principally in ufe, are either made of wickers, or of Araw.

The wicker Hives, if they bee nor often repaired, will bee at a faule, and lye open unto Wafps, Riobbers, Mife; any of thefe if thee findes but a crack, or crany, will dig her way in. And the Moufe, unlefs the twigs bee clofe wrought, although fhee finde none.

The ftraw Hives when they are oid and loaded, do ufually frnke on the one fide (eipecially if they take weet) and fo break the combs, and let nut the heny. Yor I have d vers which have been contunualy y ued above wenty years iogerher, and never 1. At Ipoontul ot horey cus of them. Hives made of the fantion of a Bell, whichticy ufe in Nurtbfolize, are not fo fubj at to tinking, but being generally large, they are not fit for fingle caitings; and belides they are colder than the globous Hives.

All things corfidered, the fraw Hives are the beft; and the Bees do beit detend themlelves from cold when they hang round togecher in manner of a Sphear or Globe, and therefore the reares the Hives come to the falhion there of, the warmer and later they bee; but of necefiry the botrome mut bee broad, !or the upright and fu:e Randing of the Hive, and for the better taking out of the combs, and the cop must rife thice orfour inches higher than the jutt form of a globe, wh-ther they bee covered wi h hackles or not, bucaufe the y delight to harg in a cone, and work ir m a point; but chiefly to prevent finh ing when they are full of honey, or yourg Becs, to which the bread crow'ned Hives are generally fubject.

So then that Hive hath the beft Thape that is likeft to an $\mathrm{ggg}$, with one end cut off, an wee ufually order it when wee sat ir. Is may confift of ewelve Atawn wreachs or lowls, 


\section{a Theatre of Political Flying Infeets.}

or more, according to the bignefs of the Hive.

Let the three fritt rowis bee of one magnieude, and compas, and abour a foot or fomewhas more in the Diameter, the four nexi above them mure large, bellying out a lictle each beyond his fellow thar the comb:s may bee mare firmly faltened: Let the other five by lickle and liecle bee nirrowed to the center a: the cop that 12 nay bee pyramidal.

And afer this proportion, if the Hive corfits of more wreaths or rowls, for this is the thape of a fmall Hive. I have fome contiting of ieventeen or eighteen wreaths.

Hves are so bee made of any fize between a buhel and falf a buhel, faith Mr.Bater. I have many Hives containing five pecks which fwarm yearly, and latt (by fuccelfion) longer than thole that are hived in fmall Hives: And although a half bufhel Hive will contain a competent ltock, yer the fwarms for the moft part are Imall, and the caftlings of themfelves worth nothing; and the Bees thas are ordinarily left when they have caft twice are fo few, that they quickly mifcarry.

However ler your Hives bee rather too litele, than too great, for fuch are burfful to the increale and profperity of Bies. If the Hives bee too great, the Bees will bee more lazy, working uncomforab!y, becaule they defpair ever to finith and furnith their houle; but yet if there bee a competent number of Bees, they will work induftrioufly (though the vacuity bee large) and compleat as much with combes as thall bee lufficient for them. But an over large Hive is prejudicial to their fwarming.

When you have provided your Hive, clip off, and cur away all the fturing Araws in the infide, and make it as fmooth as you can. The beft and readieft way to perform it, is this: Firt wer the skirts of you Hive, then hold it a turn or two over a blaze of Atraw, and then take ic off, do it a fecond cims, and if need bee a third; and after rub it wich a peece of a rubbing Atone, fnch as Mowers ule to whee their fi hes wichall. And to fhall you much cale the Bees, they wil. do it themfelves in time, but not wichout much pains and labour, wh.ch might bee more profitably imployed. Howiuever when you have ersmmed it as ivell as you can, yee. Mall ou hear ihem if you liften in an evening harping like Mile (as if Mile were gnawing on 12 every 
every fide) and that for divers nighes together.

And if is bee an old Hive, though it were multy, yet holdirg it over a fire feveral times, will fweeten it. And the Bees will better lite in fuch a Hive fo ordered, than in a new one, not purged with the fire.

Mr.Southern. Mr. Sowt bern, and others after him advile, that if Bees finde faule with a Hive, and will not continue in it, to pull ous the fpleats, and put into it a little quantity of Barly, Peafe, or Mault, and let a Hog, eat is out of the Hive, turnirg she Hive with your hand as hee eats, that the flaver or froth hee makes may remain in the Hive, and then wipe is lightly with a cloath, and having put in your f pleats again, hive your Bees in it, and they will undoubredly tarry. I never had occafion to experiment it, becaufe that I never had fwarm that I could nor make to sarty in one Hive, or osher.

Many rub their Hives before they ufe them with fennel, of osher fweet herbs, and iprinkle them allo with Horey and Beer mingled together, Sweet-wort, Milk, or fome other fweet liquor, but I feldome ufe it, but onely as I faid before, purifie and fweeten them with fire; and perhaps fet them, before they bee ufed, open is the aire a few. dayes our of the danger of sain.

I have fcarce (In forty fwarms, and more that I have had in a year) hived one twice, or had any return after that they have been hived, except when the Queen Bee hath been wasiing:

Having prepared and drefled your Hives, the next thing that you are to do is to ftick them. And various are the fafhions Mr.Levit or - thas, are obferved, fome doing it one way, fome another, Mr. dexing of Bees. Levit prefcribes this courfe. Take a ftrck of Sallow, or Hafets about the bignefs of a mans shumb, let it bee a foot long, or fomewhat more, then cleave it crofs-wife from one end till you come within a handfull of the other. end; and no further, then bend each quarter a feveral way, cutring off the Tharp edges in the midt of every one of them, then may you put the end that is not cleft into the crown of the Hive, and bending every of them a feveral way, ftict them into the fride of the Hive, that tirey may force the upper unclefs end hard to the crown of the Hive; bus if che itive have a litule hole in the crown. (an many. Arraves 


\section{A Theatre of Political Flying Infects.}

Atraw Hives have) then cut the upper end of your faid crown: rree where it is not cleft fmall enough to go through 2 likele way, leaving a houlder on the infide to ftay it:. And this is to keep the crown of the Hive from fagging down-wards as they wil do (except your Hives bee exceeding good) when they, are heavy laden with hony.

Laftly, Take a fmall ftick and cleave it clean through in the midlt, cutting both clie parts flat and fmooth, and pue them crofs-wife inco the Hive wishin fous fingers of the board they Thall ftand upon.

But this inconvenience I finde in this manner of Aticking, that they canno: beetaken out, but alcogether, and therefore the combes will bee much broken, and the boney run out when you sake 2 Hive.

This courfe I obferve; I take a willow Atick, about nine, or teninches long, and (according to the greatnefs) cleave it into feveral tbin peeces, each fpleat I thave till it will bow, then f harpning bosh the ends; I Aick three fuch fpleats in the center of the crown of the Hive, and bow the three other ends to the fides of the Hive (tha: they fand like fo many bows) and there enter them in a triangle. And then after pa: a frong fpleat quice through the rriddle of the Hive within four inches of the bottome. If it bee a large Hive, I put another crols that (otherwife not) about an inch lower.

Thas the Hives hould haveyo'es quire shrough them to prevent Spiders wibs, or by the wind paffing through to blow away any offentive matser, is an idle fancy, yer prefersbed by Floreatirus. Elorertiaus.

\section{CHAP.XII. \\ Of Seats for tbe Hives, and ibe Bee-garden:}

F. Ee your Bees bee feated not far from your boufe out of the Colunelis. danger of an eccho; not too hot in Summer, nor in too Mady a place in Winter. This counfel may bee profitable to fome, buoic is of licele varth to us where the hortelt Sun in Summer if.they bee well defended with covers, or a Peathout 
hurse them norhing, and the greareft froft in Winter (fuppofing them covered above, and alfu well fopt below) damnifics them nothing. Nay..I have found experimentally that in a row of Hives Itanding on the North fide of a long Barn, whofe height hath intercepted the Suns bearns all the Winter, lefs provifion (almolt by half) hath ferved thole Hives than'would have ferved others ftanding alwayes open to the Sun, for coming feldome forth they did cat litele, and yet in the Spring were as forward to work, and to fwarm, as thoie that had iwice as much hony (ozherwife alike) in the Auiumn before.

Some Bees will bee late at their work after Sun-fer, and if when they return they finde it dark about the hive, they mult lye abroad, if noc altogecher perifh. Let the door therefore bee lome what to the Weft.

Let your Bee-garden bee well fenced from Cattel, and as well as may bee defended from winds, efpecially lec them be fecured from the Weft and South-weft winds, which are with us molt conltant in the Summer. The time of Bees labourisg, Virgil thus prefcribes,

Virgil Gror: lib.4.

\section{Firft for your Hives a fitting fation find}

Sbelered froms woinds rougb violence, for Wind binders tbe ir carriage ---

Mr. Butler would have them defended from the rifing Sun, bicaufe it invites them so work when the aire is ctully and cold. Suppofe there were fuch an inconvenience, which yet I never found, yet where there were many hives, a fent on the Ealt fide could not defend many if any at all. And if they ltand on berches with backs or walls behinderhem, and a Per,thoure over them, they will bee at work in a fair day iwu or three bours before the Sun can fhine upon them.

And for fwarms, it is beft to uncover them on the fift thining of the Sur upon them the day after they are iet up (till they know their ftation ) that they may bee allured forth by the heat thereof, yet when the Sunfhines hot at noon, let them bee fleightly covered.

Columella prefcribes that the hives ftand with their mouths fomewhas so the Ealt, that the Sun may Paine on them in the 


\section{A I beatre of Political Flying Infects.}

morning, and make chem more early to follow their work; but upon experience, I sommend the fetting of them fomewhat to the Weft, that (being late often at their work) they may have moreligh: (their eyes being weak) io enter their Hives, and allo thar they be not prejudiced with the Eafterly winds, which are coid and huxiful. gim:

Le: their enrance be tow (ibecau'e of the Moufe) but longer in Sunmer, and horter in Winter, but in Autumn fhor. telt of all, no: having paffage for above a Bee or two at once, to prevent the danger of robbing both by Bees and $\mathrm{Walpes}$.

Som: prefer fingle tooles as nor fubject to diverfe inconveniences, which Bees itainding on beaches (as they imagine) are liable to, they are kep: faith M. Levit by Penthoures from the raine, but neither from the heat of Summer, nor cold of Wirter, for they ltand naked, the heat or coid eafily takes hold of them, elpecially any great a d long iroft.

Againe, the Wind many times makes a great noyfe in the hollownefs of thofe kind of houfes, whicl fore annoyeth the Bees; Air. Bwiler faith, that many ftalles upon a bench in Summer may caufe the Bees to fight, as having eafie accels on foot to each other.

And againe, ftandirg fo near, they fome time miftake the nexa 'H ve for their owne; and againe, in Win:er the benches will be: alwayes wer, which lnofech the cloome, rottech the bortom of the Hive, and (ffendeth the Bees; and laflly, the Moure at ail times hath free paffige from one to anocher without fear.

I have tried both waves, and found none of thefe evils that are objected, in fetring Bees under a penthoufe, and whereas in the firft place it is urged, That they are always lubjed to Heate, and Colds; I anlwer, that if any are much offended with either of theie cx-reams, they are the Hives that ftand on tingle ftools where the Sun penetrates, fometimes through the hackle and the cold winds every way pierce them; and in the Spring. when they begin ro work, wll biow nuny of the Bees from their Hives when they would enter in.

And for the neyfe that is occafruned by the Winds to Hives under a penthoure, it is lefs loud and violent than where it hath an o, en paffage on all quarters; but they are more apt to fight on bencbes than on fingle ftooles. In many years cbiervation, 
having more Hives upon benches than ever I knew any to have on Engle frooles, I never had any robbed by his next neighbour, but moft commonly (if as a 1 ) by fome of another Bce-fold; and whereas it is objected, chat in Wincer the berches will bee always wet, I anfwer, that chis objection is altegether frivolous, nay falle, for the lame caule thall wet che fingle ftooles that will wer the benches under oovers ; nay, they are much more fubiect so it, for only a driving raine from the South can wort a lirde as molt before the enuance, which the Sun or Wird wil quickly diy. when as they are liable to wet on every fide; ard for the Moule, the will more fecurely vilit them where he may

M!o Lisolox new Urchard. unleen (gecring under the hackle) eare her way into the Hive, Mr. La bos therefore commends a pecthoufe.

But if any delight in tingle trooles, let tiem be of wood ather than of ltone, for they are too hot in Summer, and which is worfe, coocold in Winter; be careful shat they be well covered with hackles, which you mult often takie off, both to diy the Hives in a Sunny day, and alio for fear of Mile and Spie. ders.

And whereas it is objected, that Bees Atanding on benches are ape to miltake their Hives, efpecially the young ones; and if a Swarme tecurn home they will lieste upon the next Hives, to their owne and cthers ruice, and thereby cccalis n a greas Lois of Bees; ro prevent this, lee them Aard half a foot at ste leaft beiween Hive and Hive (it were belt a foor) and thefe mifcarriages would be avoyded, and to fecure you from Mile, keep a Trap conltantiy on every Bee board.

Take notice of fonte advantages that this way you may enjoy, which you cannot lo well when they ftand on fingle fools; cfiencimes a foor Hive ftanding by a full neigt bour, if they lye cu', and the weather be not fisung to fwarme, they w II (as it were ) make a League of amity with them, and firf growing fam liar, will with their fupernumerary Bees (all not berrg able to work in the fuil Hive) replenilh their neighbour with bread and mear, whereby they will liwarme almolt as foon as the beit, which ocherwite would not have lwarmed that year, or very lace.

But befides (which is more confiderable) you may have much pure Honey withous any trouble, or lois; abous midde A ril 


\section{'A Theatre of Political Flying Infects.}

"April in 2 warme Spring, obferve what Hives are f:.", and begin tolye out, and fet a Hive with the Combis that the Bees dyed out of the Wincer immedially before, nexs to luch a full Hive, and you thail have them work into it prefently, and carry in abundance of Honey; of neceffry many of them muft have been idle in their owne Hive, there being no roome for half to work; they take this as a retiring houfe which they will work in, and ltay in too, night and day, only keeping an intercourle with their owne, which will f warme never the later, and as foon as by the emifion of a Colony there is roome made in their own Hive, they will goe againe to their Leader and leave their provifion; if fome few thay when you tatie it, knock them out, and they will returne to their old habitation; I had this latt year, one thoufand fix hundred fifty $f(x$, in four fuch By-hives thus garbered, in eight dayes before the end of April neere four gallons of Honey, and the Hives allo fwarmed in April; this Honey was pure Virgin Honey, as white almolt as milk.

But if they ftand a week in CMay and fwarme no: , then take the reciring Hive and carry it fome diftance from the foole, and kno:k it on the crown and fides, and they will all goe out to their owne Hive. But if you dare noe venter on this courfe, then drive them into an empty Hive, and the day following knock them out neer their owne Stock, and they will quickly return into it. By this, conjequre how much honey Bees gather in the Spring, but of this more afterwards, fo that it is neicher for want of roome, or ftooles, or wit (as fome imagine ) to fet Hives on benches under a penthoufe.

Mr. Butler defignes to fer fixty three Hives of Bees in a plo: of ground of fifty foot fquare ( if any, faith he, be fo happy.to arraine this number, which I have much exceeded) but I would rather advife to fer your Hives if you have many, at a larger diAance, if you have roome, whetber upon fingle Itooles, or upon benches, namely, no: above fixteen, or at molt twenty in a row (Aill take notice to fer them from $\mathrm{E}_{3} \mathrm{ft}$ to Weft) and three or four rodds to the Southward, another rov', and fo according to your numbers, or at double that diftance if you have roome ee nough, for it cannor otherwile but often fall out, that you thall bave many fwarmes rife together, or before you thall have Hived the finft, efpecially in a plentiful yeara :o your no lissle difturbance, 
and prejudice: Whereas fanding at that diftance, you thall more frequently prevent it ; and the more, if you have a row of trees planted thick to the Southwards of every sow of hives, fome two or three rods diftant, where they will readily light and feek no further.

Another ioconvenience of many hives Atanding upon fingle ftoolsone before another is, that fometimes the fwarms will ferte on the hackles of the hives before them, and if you bee not prefer: , and fpeedily hive them, hazzard the lols of the fwarm, and perhaps the ftock too, as I have found by experience.

Ls: the ground before your frools or benches, for a rod or iwo at leaft, bee kepe (hort with ofien mowing, for long grafs and weeds, much more Beans and Peafe are prejudicial : for the young weak Nymph falling on thole thady places (except the weather bee warm and dry) are in danger to bee chilled, before they can rife again.

Let it not bee a bare ground, for in Winter it will bee wer, and chill the Bees when they light on it, and in the Summer dutty, and falling on it if they rile not prefenily, but go little, sheir feet being dew-clawed, and fcabrous, will quickly fur, and theg will bee fo clogged, that they will nor bee able to rife a: all.

Let shem aot ftand above a foor g. or a fooc and a half from the ground at the molt, for if they Atand higher (as moft fe: shem) they are more fubject so the violence of the winds, for tbough they do well enough abroad in windy weather, gee when they return home, efpecially in the Spring, they will bee beatee down befides the hive (and the more if they ftand upon Atools than on benches) and if there bee a prefent fhoure (the wearther then is variable) or the Sun fuddenly over-caft, they will quickly chill, and perifh.

That they infectone another with their fmell if they fand too near togecher (as Mr. Levit furmifeth) I never found, nor do I beleeve. And if greas noifes offend them, the higher they fand, the more are they fubject to them.

1 have obferved tha: Bies flye more frequently to their work East ward than any orther way, though there bee as good. gathsring to che Wef?. 


\section{A Theatre of Political Flying Inferts.}

Smoak is very offenfive to Bees, let them aot ftand therefore near a Brick-kilne, Lime-kilne, Brew-houfe, or where any long continuing (moak may beat down upon them.

Let your Bee-garden, or the ground adjoynin to it, bee planeed with all lorts of Plumbs, Cherries, Apples, Pears, Goof-berries, Ralps, Ribes, and beds becween planced with all forcs of flowers that shey delighe in, I will give you a Catalogue of them in theirproper place.

The humble Plains, or lowly Vallies are commended as the Colums?. belt place for a Bee-garden.

\section{CHAP. XIII. \\ of the Bees work:}

TT Hen the Earth begins co put on her new apparel, asd the Sun runs a molt even courfe between the night, and the day, then molt commonly, fometimes before in warmer feafons, the indultrious B:e hating idiene's more than death, diligently vifits every tree and flower that may afford her materials for her livelihood. Hear how an ancient Poes exprefCethit.

When forgo: bad the Earth bis poor eftate of Winter, that bim naked made, and mate, And with bis fword of Clood fo fore grieved, Now bath the alt cmpre Sun all that relieved, Chawcer Pro* logue to the legend of good Tbat naked was, and clad it new again, The bufie Bees of the fedfon fairsos.

Pliny was deceived in the time of the Bees working, for hee faith, they lye quiet in the hive untill after the rifing of the Vorgilie, which are the Pleiades, or leven ftars in the neck of $T$ aurm about the third of May.

This inceffant labour while the time permittech, with the three fingular effects thereof, working of wax, making of honey, and the feeding of their young. The Poer in few words hath elegantly expreffed. 
But when bright Solbatb tanifod Winter chaj'd

Virg.Geor.l. 4:

Under the Ealth, and $S$ ummer ligbt batb grac'd

The skie again, over tbe frolds and woods

They wander freis bt, lagibuly the brivks of ficods;

They fip asd safe ibe purple fowers, from ibexce

(Wisal faectrefs ere it bee that ftir skeir len/e)

Care for tbeir broos', axd progeny tbey take,

Iosmce worktbeir wax, and bonj clumsmy make:

Ar'tede hist. Bees gather of all things which havc flowers (as it were) in a Animal.l.s. bole or focker, and if all other things whoch are fweet; c.19. butercher affertion is too general, as wee will thew when wee patticularife what they gather of. Scoliger commenting upon him, goes further, and faich, They gather alfo of bitter, and Tharp things, as Raddith, and Muftard-ieed, but hee miltook bimfelf, for the flowers (which they onely gather of) are aeither bitter nor Marp.

The fabrick of their combes is an inimitable excellency, Fli $n$ I s.c.2. without all rules or compaffes do they make their hexanole cells. As foon as chey are furnifhed with a thew houfe, they begin their work.

They ga:her not, whatsoever fome groundle fly imagine of the Arif.de hil. Sallow, Elm, or other trees any gummy lubftance orher than Anrmal.! g. wax. Indeed the Hornets, and Wafps fuck the fap that leaks C.2 2 , from fome Oaks, Elms, and other trees, wherewith they cemperthe diy roffie drofs, thar they cynaw cff from old decayed pofis and pales, of which mixed engecher they frame their co bs.

Much adoe the Arcients make about the fe urdation of their work, which they conceit to bee framed of fome tough and glutinous matter other than wax, and they fancie a triple foundarion, for the combes, all of juch cough, but pliant, and limber fuff, differing fomewhar one from another, and all from pure waxe : The firt foundation they call Commofis : A lecind, when they over-lay the former with Pifjicera; and the third, wherewith they cover the wo former Propolis.

But whatioever they fancie, the foundation of the Combs is not any other than ordinary waxe: Take an o!d Hive wherein fome remanas of the Combs have been left Aicking to the fides, 


\section{A T beatre of Political Flying Infects.}

fides, or if there bee none, fixe towards the crown of the hive in feveral places, little fragments of waxe, and hold the hive a little over a blaze of ftiaw that the waxe may melt and d ffufe about the fides of the hive, and fuch a hive will they more conteatedly work in than any other, prefently to that foundation of wax, faltening wax new gathered from the flowers (for in fome Iflands plentiful of Bees, there are no trees forfome miles, as Fowlnels, \&xc.)

They falten the firt wix near to the center of the hive, if they bee many, but if there bie few Bees then noar the fide, they make their combs perpendicular, beginning at the top, and foworking down to the bottome; the heat of the Bee (that I fay no: of their breath) makech the wax warm and pliable, that at the firt gathering they can work, and turn is to their furpole.

They will not oncly wor's artificially the wax they gather into thin hexangles, but blow and foften, and work a folid peece of wax into a comb, as I have often experimented, putting a feece of wax under a hive almoft sombed to the board.

The order of their work is thus: They faften sheir firt wax to the hive, and adding more Atll, make firtt the middle between the cells, and having wrought a litcle of the thin bottome, than on either fide begin to raife the hexangle cells, and fo ftill dercending to the botrome, as fome are fully finithed, others are but half way, othe:s ne $w$ begun.

Their combes are placed otherwife than the Wafps, for the Wi . $\rho$ s hang theirs one under another, and the Beestheirs one befides another, biginning it Il at the top, and at that diftance that a Bee may reach from one to anocher. And ufually fuppolyng them to Atand with the entrance into the hive Southwards, they falten and order them lo, that in the breadth they are from $E$ ilt to $W=A$, thereby be:ter lecuring themlelves from cold.

Their cells are made fix. quare, according to the number of their feet of that length and wideners that each of them may eafily contain a young Bee. More particularly they make their Bafil Hexem, combes with fuch artificial prudence, that they feem to out goe Homil.8. Arcbimedes, for the wife Bee is not ignorant of Geometrical inventions, allher cells are hexangles, and have equal fides, 
not leaving by courfes right forwards, that the lowet being joyned to the empty one, may not be preffed or prejudiced, but the angles of the loweft hexang'es may be a bafis and fupport for that that leanes upon them, that they may fecurely hold up, and bear the burdens put upon them, and the Hony may be contained leverally, and apart in every cell.

And agaioe, the Bees contrive their Hony-cels both wifely, and artificially, fordiftending the Wax into a thin membrane, they frame together many and numerous cells, that by the fre= quency of the binding or knitcing of the fmall cells one among a. nother, there may be a ftay or prop for the whole work; for every cavity or cell cakes faft told of his fellow, being feparated by a fmall divifion from it, and all joyned to it.

And laftly, thefe pipes, or cells, are twice or thrice arched,

Nicetra comment. in Greg. Nizizn. orat. $43 \cdot 60,2$.

Elias Cresent. Antiat. comoin Greg.Nazinn. orat. 2. de tbeol. and framed together like the rafeers of houfes.

Or they thus make their hexangle cels, which with a divers and oppofite order anfwer one another, for fome are placed at a right line, others are inftead of foundations to them that lye up. on them, and Aaies for the hony, both for the elegancy, and alfo the lecurity of the work; fo wifely and skilfully doth the fabricate her Store-houle, for drawing out the Wax into a thin skin, or membrane, the makes thick and concinued cavities, 10 as that thick compolition of [mall things among themfelves doe fultaine and underprop the whole work, for every cell doth joyn or hang to his fellow, being divided by a fmall partition, and allo (as before) conjoyned together.

In a word, the cells are fo framed that they have two or three floores or rafters, for the is affraid to make bur one through the whole cavity, left the hony preffed down with the weight, thould fink to the exrernal part.

Now all the cells in every Combe are bexangle, and equilare$\mathrm{ral}$, not leaning ftraight forth one to another, leit the loweft parts joyned to the emp:y ones thould be too much burthened, but the angles of the lower hexangles are inftead of a bafic, or prop to the fuperiour. After this făhion the Bee frames her work, yaryino right lines with angles.

And thus laith anorher, where had the Bees fuch fudious induftry and workmanhip, that they fhould after fuch diverfe manners knir rogether their Combes by hexangle Pipes surned 


\section{A Theatre of Political Flying Injects.}

one againft another, which connexions made wifely, and with much cunning, doe hold together by hexangle pipes, which pipes are the long and concave Store-houles for the Hony; now thefe are oppofire to, and curned one againft another, for fome are placed Atraight, others on the contrary are obliquely ftretched forth on the bottomes of them which are drawn forth right, which doe afford their fides for the pipes that hang over, inftead of 2 foundation, and as it were a Mhore, whereon the hony may reft.

Now what Euclid bufied in reprefenting lines which are no where, and anxiounly labouring in démonitrations can imitate them? The frame and manner is molt curious, with holes on both fides of the Combes, many hundreds, and yer they are none of them juft one againft another, but placed triangular one among three, and that molt neatly and artificially, which argueth their feeling to be good, for they doe all in the dark.

Each hexagonical bottome of one fjde, anfwereth to three Mr. But. Fera, chird parts of the hexagonical bafis of three contiguous cells on mon, $c_{0} \sigma_{0}$ the other fide, oppofite bottome, as in this forme; cial, as well for ftrength and beauty, though the thin botrome of his cell

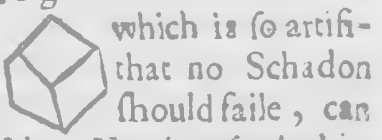
break thorow into a cell of the other fide. He that feeth this reech he not a wonder?

How much Was they bring at once doth appear by the new Swarme, whore firft weeks work is fpent chiefly in building Combs, wherein they are fo earnelt, that it fallech out with them, as it is in the Pioverb, The more bafte the wor/e Jpeed; for part of many of their burders doe fall trom them before they can faAten them to the combes.

You may fee great fore upon the foole by the skirts of the Hive, like unco the white fales which fall from young Birds feathers ( but whiter and brighter ) and therefore fome have imagined that they alfo are fcales, which the young Bees doc likewile fhed from their wings; but put you lome of thefe parcels together, and you fhall quickly be refolved of that doub?

The Swarme when it begins to work falls low to wards the botcome of the Hive (in appearance filling it ) that there may be a vacuity and hollownefs above, that thors that work (for at 
firt all cannot) may neither be crowded, nor difturbed, but as the Combes defcend, fo doe the Bees afcend, and after a week or ten dayes will be all above.

Now to fay fomething of their gathering of Hony, which they ferch in litele or much nine moneths in the year; this is of two forts, the one pure and liquid, called therefore by fome Nedar, as theorher which is grofs and more folid Ambrofia, and both of ehem are the Bees food, but in feveral feafons.

The grofs hony Sandaracba, or Bee-bread, is gathered by their tongues, with the affiltance of their fangs, from whence it is conveyed by their fore- leggs to the thighs of their hind-leggs, and that fo nimbiy, that unlefs you have a quick eye you cannot perceive it. In the Spring, when the air is colder, and the Bees duller at their work, it is more vifible: namely when they gather cff the Aglets, or Catkins, of the Hazel, or the Willow a little after:

Many out of curiofity have fuppoled, that they might be able to oblerve the Bees work if they had a tranfparent Horn-hive, Guliel. de Conchis. as a certaine Conful in Rome had, or a clear Glaff-hive; but the varity of this opinion will quickly appear to any intelligent and rational man; for imagine the Hives were more tranfparent than Chrylta', unlefsthe Bees alfo, and all their work too were tranfparent as well as the Hives, this cannot be; put an opacous body into she hollow of it, your fight is dulled and darkned, but more when they once begin to frame their Combes, the foundacion of their work, which they frequently compals round about; and howloever fuch Hives would not be profitable, for they are fubject to violent heats and colds, and therefore earthen Hives were juftly condemned by the ancients.

* But if any be defirous to fatisfie himfelf, as much as is poffible, I will dırea him in a more certain way, ofien experimented by me, yet I fay nor, that I will altogether undeceive his expettation.

Let the board or plank whereon the Bee-live ftands have a finall hole, or cleft thorow the middle of it ( bigge enough for a Bee to goe through) or let the Hive ftand a little over the board or foole, and when the Hive is full you thall ordinarily have them work Combes to the botrome of the board under the Hive; I have had under one hive fix or feven Combes about a 


\section{A Theatre of Political Flying Infects.}

foot long a peice, wherein they bred their young, laid up theis hony and Bee-bread as in the hive; and alchollgh they were in the open air, yee was I ehereby litele the wifer, only lometimes in a colder feafon I have obferved them blowing, and working of rhe lower part of their Combe, bu: was not any thing at all enabl d to undetfand the gerreration of their young, or other curiof ies which were performed in the in molt combs, and within themfelves (excepe the Bses and their work too, had been tranfparens) they fill fome of them encompaffing she ir work; and cherefore excepe you can with your eye pener rate a folid body, you will conceive thereby lietle of their work (only fometimes on the edges of their Combs) and much lefs in a Glafshive.

They unload into the empty cells the Bee-bread which they have gathered for fond for themfelves, when they carnot goe forch to work, and alfo to feed their young, but if it continue any long time uneaten, it wil grow dry, infipid, and tower, and chere = by as taftlefs, fo ufelefs, and of caufe the Bes to forfake their Hives (as fome luppole) but this is never the chief caule of their departure, but rather paucity and fewnels of Bees, having over-\{warmed, or elfe the lols of their commander. For, hive a fwarm into old combs where is inuch ftopping,yet tha! you finde that they will thrive wel, for they wil daw it out of the cels with their fanus, and carry it forth. And lec the combs be never fo olds excep: they have taken we', and fo be rotsen and crifpie, they wil like well of them, only if they be very o!d, they will doe as $\mathrm{Ma}$ fons doe wich old tone buildings, take down the out-part and work it again with new materials, whereby it thall be as good as new, and they continue as long, and as well in them, as if they had been pur into new combs.

Into old combs (a fer nine or ten years ftanding the Bees by calualey dying) I have hived litele or lare fwarms, which have continued in fome of them cen years more.

Somecimes my owne, fomecimes my Nighb urs Bees have etimmed up fuch Hives as they have found ltanding (the Bees being dead ) and have gone of themt lves into them, and thrived bitter than others nived inro new hivcs, or new combs ; fo that blacknef: (as it is commonly thought) is not an infalible figne of a fauley birr, for the combs hare fuccelfively furdaty colours. 
The firft colour is whire, which in a goud Hive before the crda of Summer will turn to a ight yellow:, ald by the begin. ning of the nex: Spring, this light is charged into a iad coicur', and lo by degrees it becomes brown, and chen black, but nor to all pars of the Hive alike, for the combs will bee black before, and brown in the middle whenthiy are yellow, if nor whire in the backward con.bs. And this alieration of colour, is caufed by the hear of the Bees, wholying for the moft part before, do fooneft difcolcur hem; bus the biackift combs (rried or meltcd) wili turn agano to yellow.

it is nor a mifs (efpecially if the Hives bee poor) to cleanfe away in the Spring the drcls and fith that the Bees have cortracted all Wincer when they could not go abroad, tu: for fumirg of them, as fome tequire, Inc ver lave ary caufe, ror found any profic in many years that 1 have been converfant amorg them.

To feek (as Varro requires) if there bee divers rulers, becavie divifions would make them laze, is a ridiculcus, if not impoltible task: They kill afeer the latt fwarm all of the blood Reyal, and in the Spring catly breed new, that they may bee ready to go with the fist fwarm.

The Vuluar when they fee the Bees go home laden with Ece-bread, luppole they carry way, and i. they call it, but if you tafte it, you will eafily refolve your (clf.

Befides, if you would coagulate is icge her, with the teat of your nigers (as y cu may wax) you camnot, bur thal! finde it crumbir, ard not frick trgecher line wax. Fut it into the fire, it will nor melelife uax; befrder, it is of divers colours according to the qual ty of the Howers, or plants whereof it is gathered, fo that by the colcur with a litrie oblervarion, ycu mây fay of moit of the Bees, when they return with it, whers they have been cacheling.

Tafte $\mathrm{i}$ : when it is rew gathered, it is fweet, and nos unplealart, but not fo fweet as horey.

Anc that is is nor wax, take notice of an old flock into which they carry plentifully of it, and yet atrthe end of the year these is no more wax (if fo much) thenthere was in the teginning. Whereas a fwarm will lometimes wok down half thes- hive in a week, and yee you hall feetlem carty lute of is if ary s. $3 ! !^{2}$ 


\section{'A Theatre of Political Flying Inferts.'}

And the reafon that the old ftocks carry in fo much, is, b:caufe they 1 , re many young ones to feed, whereas a fwarm for the firt ten dayes, ordinasily have not hasched much [pat, or young brood, and they feed fur the molt part abroad, and therefore need listle of it in the Hive.

The liquid honey the Bees fuck or gather with thcir tongue, whence theylet it down into their buttles, whieh are within them like bladders, each of them will hold a drop at once, you mayfee their bellies Arue withall. Many think becaule they fee nothing on their thighs, that they come home empty, but they are better, and more heavy laden chan the other.

This fedulous diligence and indefarigable induttry of the Bees is moft evident and eminent in the Spring, after they have been long confined to their hives with the Winters froft and cold, but being fet atliberty by the Suns warmer beams, they fpeedily fcoure over hills and dales gathering of every bloffome, and flower as greedily as the griping ufurer grafpeth gold, which diligence of theirs, is notably exprefled by a Modern Poet.

Q nales vere novo ficule e fub collibus Hyble $\checkmark a k i b u s$, aut riguis late fragrant is Hymetb Exercentur apes, frabslis abi pinguibus agmen Prodit maxe nounm, of cclo bascbatur aperto. $H_{e}$ ver is populastar opes, Tymbreque laborant: Illa Apii lachrymam, on graveolentis Centaure Narciffique legunt forem, Cafiafque rubentes:

Calera dun legio teet is af cripta, tenaces Suspendunt coras, of mella liquenti a fundunt.

Thus in the Spring the diligent Bee fpreads forth her wings, yet ftiffe as it were with the Winters cold, and with halte leaving the hive, flyes to the flowery Meads and plealant Gardens.

But for your further delight, confider the Bees labour, in the words of one of our beft Englifh Poets, yet fomewhat alcered, becaufe not intended by him for this purpore.

The Woods, the Riveis, and the Meadows green, Wilt ber air-cuttin, w ngs, Be meafuret? wide, L 2 Greg.Nizian. orat. 43.6 .2$.

Alius Julius Cror2. Eid yl. 3.

(n) 
A Theatre of Political Flying Infects.

Ne dotb pee lewve the mosiniains bare wnjeen, Nor ibe rankgra asic Fens delighes untrid; But none of $t$ befe kow cver fweet tixey been,

Mote pleafe ber fancy, xor canfe ber t'abide Her cboiceful (enje witb every cbange dotb fit, No common ibings may pleafe a wavering wir.

To the gay Gardens ker unftaid defire

Sometimes ber carrieib, to refrefth ber Sprigbis,

T berelavifo rature in ber beft attire

Pours forib fweet oders, and allurirg fig bits, And ars witb ker cortending, doib alpire

$\tau$ 'excel ebe natural, with made delights. And all that fair or pleajant may bee founds In riotoses cxeefs dorb ibere abownd.

There fhee arriving, reund about dorb fye

From bed to bed, from one to otber border, And enkes (rivey aitb crious buse eye,

Of eviry flowre and berb there fer in order:

Now itis, now that, pe tafterb terderly,

Yet nore of iben ftee rudely dotb diforker Ne witbker feet ibeir fulken lecues defoce, But paftures con ibe pleasur es of each place.

And cuermixe witb moft var iety,

And cbarge of fweetnefs (for all cbange is fwiet) Sbe cafts ber tafting lexse to fatiofie

Ncw lucking of the biocms of lierbs moft meet;

Or of the dew, nabicb yet on tbon datb lye

Now in the fame balbing ber iender fect. And iben Shse pecrchetb on fome transb iberety, To meatber ber, asd ber meift wisgs to dry.

Ard iben again fbee tarnct.b to ber play,

To pioslibe pleafures of that Peradife; The molefome Sage and Lavender frill gray,

$S$ weel Carrowayes, and Cummin good for eyes; The Rofes reigning in ibe pride of $M a y$,

Sbarp IJop, good for green wounds remedies; 
A T beatre of Political Flying Infects.

Fair Marigolds, and Bees alluring.Tbyme,

Swect Ma, juram, and Dayjes decking frime.

Cosl Violet', and Burrage growing Pill,

Embatbed balms and cbearful $G$ alingale

Goodly Tulips, and breaibful Camomile,

$D$ w B Poppy, and drink quicknirg letwale,

$V$ einobealing $V_{\text {ervin, }}$ and Heacharging Dill,

Sound Savory, and Bafil beaity bal.

Fot Cole- Horts, and comforting Strawberry,

Cold Letice, and $r \in$ frefaing Rofermary.

And wat foelfe of vertue good or ill.

$G$ rew is the Garden, fetcbe frem far ariay.

Of every one (bee takes and tafies at will.

And in ibeir pleafures greodily doeb prey. or.

\section{CHAP, XIV。}

Of the forming:and biving of Becs.

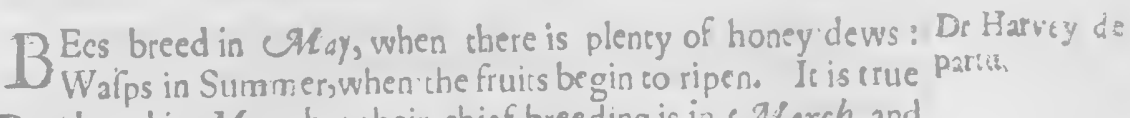

Bees breed in May, but their chief breeding is in March, and Airll. And alchoughthe Walps appear not in great numbers unill the latter end of Summer, yet ihey beuin to breed in the Spring.

The old flocks having bred in the Spring, and woie's a new fupply replenifhed their hives, they prefencly prepare to fend forth a Colony or two (if the weather prove teafonable) out of every good fall.

In extraordinary dry and windy times, many, though they bee' full, yet they will not lwarrs at all. For having waired long for an alteration of the weather in vain, and the year wearing away, and they by lying forth under, or about the fides of the hive, cooling themlelves, and being well provided for, are loathto lsave their labours to go anew to la bour.

Sometimes it fallsout, becaufe they have no Commander L 3 ready, 


\section{'A Theatre of Political Flying Infects.}

ready. I once had a very goad hive full, and mulcitudinous with Bees, and yer never fwarmed in many years, I was refolved to let them alone, to try whecher they would ever fwarm; in the eighth year they fwarmed twice, and alfo other years after, what might bee the cause of their long delay, I cannot certainly affign.

The fwarm confifts not of younger Bees, then the ftock, for there go forth both old and young, and therefore Ariftotle was Arift.de bit. deceived, whofaid that the fwarm confifted ofyoung Bees, Animal.1.9. $c_{6} C_{4}$. and was not contradited by Scaliger commenting upon him.

The fwarm parts not into feveral companies, but when there are more Queens than one. Some Drones go along in every fwarm, but not many, fcldome a dozen: And therefore whercas fome lay it down as an infallible rule, That thofe fwarms that have not many Drones will not thrive, is not al wayes true.

Many times the weather proving ftormy, and cold, the Drones will all bee Parved, when as the Bees will fupply themfelves by going lomerimes (hough feldome) abroad. Nay the Bees ofcen in fuch feafons jealous of their own fafety (and knowing them to bee great devourers) will kill them; and yee the weather proving feafonable, afterwards have thriven and profpered well that year, but perhaps they had a conceptive power by a mafculine vercue from the Drones before they fwarmed.

It is impoffible to determine the precife time of the year when Bees will fwarm, but by the forwardnefs of the Spring, and warmnefs of the weather you may probably guefs.

A warm, calm, and a thowring Spring caufeth many and early fwarms; but it is to be fuppofed if ftormy, cold, and clofe weather follow, net a great while together, immediacely after. I once had many Hives (the beginning of the Spring being milde and warm) very forward, io that by the end of Alarch they began to lye forth.

And alchough the weather within a week of April, did fomewhat alter, yet (being full of brood within which came daily to perfection, they lay forth in abundance by Mid-A pril, but the Spring continuing tempettuous and cold untill a week in May, ten of the very beft wholly ferihed, having many mouths 


\section{A Theatre of Political Flying Infeats.}

mouthes and no meat, and not being able ( becaule of the cold) to goe forth to gather any, in Iamuary before; I $2 \mathrm{~m}$ confident the whit of tham had not lets than three quarts of hory.

Now thole that were poer and weak began nor to beeed fo early, and though they were not fo well fupplied, yet had they few mouthes as they had a little meat, and endured the extremiry, and fearmed that year, but fomewhat later than ordinary; the firt fort lying forth without the Hive l could nor lecurcly feed them, which otherwile I would have done, when I perceived them to perifh.

Sometimes allo in regard of the uncertainty of the weather, carly fwarms are nor the beft; in the year one thouland fix hundred fitty two, I had iwenty fwarms before mid $M$ aty, and many more after, and of all, bue one furvived until the nexe year, for the year was fo dry that by Midfummer there was fcarfe any fluwers, and they yeclded little hony, except in the Woodlands, where the Bees among the moytt and thady places found better provifion.

Many times May fwarms prove not fo well as thofe that are caft in the beginning of 7 use, the Wind of times continuing high and cold, and the feafon clole, fo that without a litele refrelhing many fwarms are like to perifh.

If a lwarme by bad weather be checked, and hind:ed in their work the firt? week, they will leldome work couragiounly all the fummer following.

Dry weather makes plenty of toony, and moyt of fwarms, fo that when a dry fummer follows a moytt fpring, the Bee-folds A. iif.de $\mathrm{H}$ in. are rich, but if the fummer be alfo moyft, the increafe of Bees arimal.i:b. 4 . will be great, but becaufe of the farfity of hony, this increare c. 22 . will prove a decreale; the more fwarms you have at the end of Mr. Betler, Cummer, the fewer falls thall you bave at the beginning of the Fem. Mon, next, for except fome very eatly fwarms, and fome good ftocks which cuft betimes, or riot at afl they will all dye for hunger ; and the realon is, that the weather keeping them much in, they can doe nothing but breed, and when they goe abroad, bring in nothing but Bee-bread and water, wherewith they feed their young, but can finde noching to lay up in ftore; to that moyt weather gives them two caukes of fwarming, yenty of Bees, and 
penury of Hony; the one makes them ab'e, the ocher willing, and then neither Winds, n.) Clou is, nor Rain can ftay them, whereas in times of p'enty it is otherwife.

Arift de Hift. Before they fwarme fone daies, they will by a peculiar and Animal lib.9. diftinct voyce, make it known throughout all the Hivs, as in the c.30

Virgil. dif idging of an Army by the found of Trumpets, proclaime, pack up, and be gone; fo that as a prefage of the ir fwarming, there is a peculiar found heard two or three days before.

Is beard refembling Trumjets winding roy/e.

Mr. Muff. Mr. Menffet miltakes this place Arangely, and applying it to Theattum In- the Bees, faich, When the Bces for the Queens tyranny will feso,

Viaro de :e $\left.\sin l i c_{2} a_{3}\right] b_{4} 3$. forfake the Hive (which falls out at the Greek Calends) there is a peculiar and folitary voice, as of a Trumper, heard two or three days before: when there fnre they are ready for their flighr, away they goe, and if the Tyrant whom they forfake follow them, they put her to death.

But this vuyce is not at ail, or but fome few hours before they goe forth uith their firft Colony, it is true indeed aiways of the af.er fwarms, but by the way, if they hear not at all, (which Ariffotie eliewhere denies) to what purpore were this Eall, or proclamation to make ready to be gone?

The fignes of the firft fwarms are fomewhat uncertain, but lying out, abour, or under the Hive, in the mornings and cvenings oriy, is a very prcbabie figne of fwarining, whereas to lye our conflandly, is a figne of not fwarming.

When they will prefently fwarme y ou may fometimes know, by heir gathering together without as the door of the Hive, and not crily upon the Hive, bur on the ftoole alfo, where when you fee the m beg $n$ to hang one upon another in fwarming cime, and nor before, and to grow into a clutter that covers the ftoole in any plaie, then be fure they will piefently iff, if the weather hold; but commorly fome few doe finft fly for:h to and fio the Hive doo; with a grearer noyfe than ordinary, and fo allure out more company unto them, and when by this means they have go: out a pretty many, the noyfe siade by them is more fmart and vehement, when they begin to dance before the Hive, and makirg many circling inoticns turning from, and yet acaine re-

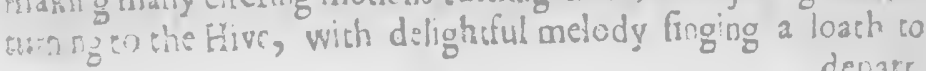


depart, invite all their Silters to halten apace, and wait upos their Queen now on her coronation day.

Their murmuting fnall Trumpers fourdes Wide, Woiles in the air tbeir claftring army files, T bat as a cloud dotó Seeme to dino tbe skies.
Spenies Frery, Q. lib, 2. cans: g.

When Bees lye continually forth of the Hive, they ufually fwarme late, fometimes not at all that year, the reafon thereof is, becaufe the Hives being ful of Bees, and therefore very hot, the Bees to refreth and coole themfelves lye abroad under the Hive, or upon the fides thereof, whereby the Hive never feemes over full; and they having ufed a while to lye forch, finde no inconvenience from their mulcitudes, and are loath to forfake shat plenty which they have painfully gathered.

If they begin a Combe under the board, it is a fure figne of ros iwarming; fweep them down that hang under, and imbitter the place, and gently drive them into she Hive with a bruh of wer ftinking weeds, or fmoke them in, as you fhall be more fully informed afcerwards. But doe what you can, fome Hives. wil not fwarme at all, or not a great while, perhaps they want a Leader.

Always choof a Hive anfwerable to the fwarme, a forward fwarme if great, may be put into a Hive that consaines fomewhat more than tbree pecks, bur if it be a prime fwarme, in the beginning of lmme, into a Hive containing three pecks; if at Midfummer, into a Hive fomewhat lefs, bu: I like no Hive thas holds not fomewhat above half a buhel.

By shis time the fwarme is fecled, goe prefently therefore to hive it ( having Hives of all forts alwayes prepared) for fear of rifing again, or of others coming to it.

If it be in the heat of the day, and the Sun thine uponit, it will not ftay long, if it be provided of a place (hive or tree) as fome are before hand; prefently after they are fetled, and all cheir company gathered togerher, they wil unclutter, rife againe, and be gone, and $\mathrm{Ay}$ forth right shither ( not as at other times uncertainly) and wil not be itaid by any courfe you can take. If they be not provided before-hand, as foon as they are gathered epgether, they defigne, or cmpower fome of their company to 
efpy out one, and if they return with the news of it before fwarming time bee palt, for that day (and they yer unhived) they will prefently unclutter, and away, otherwife they will hang untill the nexs day. They therefore deal indifcreetly, that let their fwarms hang untill night, lofing thereby many, and hindring them in their work; for as foon as they are hived, if it bee not late in the afternoon, they will prefently ply their work, and fometimes make a comb 2 handfull long before night, and fill much of it with honey, as I have of en found, when I have united them to another.

And befides by long hanging, they will bee wonted to the place, that for fome dayes atter, they will hanker thereabours, and neglect their labours.

And where there are many Hives, there is great likelihood of others rrfing, and then if they bee within hearing, they will Ilye ail rogether; beftir you therefore to hive them prefently; and if you efpy any other to arife before you have done, ftop them up with a eloath (and when you have difpa: ched, let them out ) but if you have finithed before they come forth, or come towards you, cover the firft with a heet untill the laft bee fettled ellewhere. But if they flye about the covered Hive, feeking to enter there, fet down a prepared empty Hive by it, and they will often go in of themfelyes.

But if two prime fwarms rife together, then there is no prevention, but for the moft part they will fettle together: Hive half of them into one Hive as near as you can guess, and the remainder into another. And if the Queen Bees be divided, they will continue feverally, otherwife, will go out of that Hive where is no Qucen, into the other. When they are all entred into one, knock them down into a fan, or upon a very broad board, and fer two Hives over them, having firft laid fticks ap long in the fan to bear up the Hives a little from the bottome, that the Bees may on every fide eafily enter in, and with a wing or bruh of weeds, fweep fome to one, and fome to another, as equally as you can. But if notwithlfanding all your endeavours, they will go to one Hire, then ferch a weak cafting, and knocking down near balf apon the fan, carry the other away the diffance of a rod, or more, and fet the caftling over thofe in the fan, and fo thall you have two good Hives howloever? 


\section{'A Theatre of Political Flying Infeets.}

If your fwarm light upon a bough, thake them in gently, and fet them upon a board or fan, underneath the place, having laid two Aticks firt (near an inch about) about half a fooc alunder, to rear up the skits of the Hive, that no Bees may bee coufhed by the Hive, and the Bees may more readily enter. And if any rife as (ufually fome will; , hake them down, and lay a handfull of May-weed, Wormwod, or other wee herbs in the place where they fetled, and they will quickly remove, and goe to their fellows; but if they light very high, then carry up a cloath with you, and cover them that you have in the Hive, and brirg it down with the mouth upwards, and fet them bilow (oo 3 fan as before) and ferch the remainder in another empty Hive covered, and when your are down, knock them out by the tide of the former, fometime you nutt do it, a third, nay a fourth sime before you have all.

If they lighe upon the body of a cree (they will bee trouble: fome to hive) you cannot take half of them in at once, but fweep with a wing or brufh of weeds, as many as you can, and fet them undernearh the place, and fetch the remainder, as be= fore.

Sometimes it will not bee amifs to faw down gently the bough (when you cannot otherwife well come at them) where they hang, faftening artt a lietle line to it, and fo foftly let it down, or elle bring it down in jour hand. I have brought down many, and hived them witheafe below. At other times when they have been very high is the middle or out-fide of a sree, I have carried up a fan, and fatened it by the ears underneath the fwarm, and fo hived them as eafily as if they had been near the ground, fering them in the fan, laying Aticks firt in it, as I prefcribed before. And in the evening without any trouble, feccted them down, and fer them in their place.

The manner of hivirg is very various and manifold, by reafon of the many and d fferent circumftances of the lighting, or pitching, that it can hardly be taugh: by rules, bur is rather to be learned by ufe, and experience, guided with reafon and difcretion.

If they fertle nn a dead hedge, or on the ground, fer the Hive over them, under-propping it if there bee caufe, and with a handfull of we: weeds fir them fofrly underneath, and they will. 


\section{A Theatre of Political Flying Infelss.}

go up; and to allure them the fooner, anoint the edges of the Hive with a lictle honey, and fprinkle a litcle within it.

It will nor be amils ro thred, and order here and there fome buughs of the trees in, or near your Bee-garden, that they may hang cut, as it were from the reft more opportunely to entertain the Bees when they iwarm. Yer in places where are nether trees, nor dead hedges, they will fertle upon pales, nettles, mallows, they will refufe nothing they readily meet with; fometimes on the verygrafs: Thus in the Inand of Fowlrefs.

To caule ftrcks that lye out more fpeedily to fwarm, divers

Mr. Butler Fem, son.csso rules are prelcribed. To keep them cool by watering and th:dowing of them, and inlarging, of the door, to give them aire (alwayes provided that there be noback-door in the Hive) I have with a contrary courfe occafioned their fwarming, firf rubbing the bottome of the ftool againt the door well with wormwood, or the juyce of Eider, and all the fides about the door, and laying wormwood, or May-weed allo, clofe to the mout $h$, and alfo before, above the door; which beirg done, I have in the heat of the day taken off their cover, fo that nor being well able to continue in the Hive, nor yec to reft under it, nor on the fides of the Hive, they have prefently fwarmed.

A recond way prefcribed by Mr. Butler is a when they have Jain out (although they have had fit weather two or three dayes) then the next calm and warm day a listle before noon (when the Sun thineth, and you fee no clouds coming to bide it) put in as many as you can with your biufh (it is better to froak them in) and (weep down the reft, not luffering any to clufter aga:n : Thefe rifing in the ca!m heat of the Sun, will make fuch a noife, as if they were fwarming, which theit fellows hearing, will perhaps come out unto them, and begin to fwarm. It is but a gerbapz, for 1 have leldome feen this courfe fusces.sful.

When all hope of the ir fwarming is paft, in fome evening while it is yet lighs (faich Mr. Butler) holding a Hive under thore that lye out, cut them off with a tight thred held Areight between ewo hands, and carry them to an over-fwarmer thas you would mend, knock them down on a table clofe before his Hive, intowhich,becaure they come withou: a Prince, they are 


\section{A Theatri of Political Flying Inferts.}

quietly admitted, and quickly united under one Commaboder: Stay there, I have ofien tried this courfe, but without luccers alwayes; for though they bee withou: any great contef admitted and continue there that night, yet the dry following, they will securn to their old Hive.

See here the difference becween a voluntary emiffion", and a compulfiye; when they go forth with a Leader, you may pur them any where, for they have by a voluniary departure, excluded themfelves from their former lociecy, and to recurn thither again, excep: it bee in a fhort fpace, is capital: They are reputed as enemies, forlaking their own Commander, and going away with another Leader; but if their Princefs in a ihor fpace return with them, there is no queftion about their admifion; but if by a wile they are taken from their own company without a Leader, they will recurn back agrin do what you can, excep: you carry them fo far that they know not the way,

Mr. Butler for fuch Hives as have not fwarmed before Midfummer, direes this courfe, to double the fall, by rurning the skirt of the Hive upward, putting the crown into the rim of an old Pale (or the like) well ftaked about, that it may ftand falt, and fetting an empry prepared Hive faft upon it, then dawb them (ir.the middle where they are joyned) round, onely leawing a paffage even with that of the old Atock, and they will afcend into this, and breed, and work as well as in the old. And in tie end of Auguft, you may drive them all into the aew, and rake the old for your labour.

This courfe feems plaufible upon the firft propolal, but upsn frequent trial, I have found it to little purpofe: For the Bies having many young ones in che old Hive, and much mear, will not afcend, but as they are necelfitated for room, and then work their combs to the old, upwards, and not downwards from the top of the Hive, newly fet over tham ; fo that by parting of the combs which will not bee withour trouble, you may rake fome lietle profic of the combs new wrought, but mult continue the old Hive to ftand Aill, excepr you mean to take all, I never found any to have wroughe above half way upwards, fo that ha* ving no foundation, but the old combs, it is impoffible to fet down the new Hive. 


\section{ATheatre of Political Flying Infeets.}

Bees will fwarm any time of the day, between eight in the morning, and four in the atternoon, but the chef time of fwarm:ing, is between eleven and one. Many frocks when they are difpoled to fwarm, will rife in a cloudy leafon ofcen before the Sun fhice upon them, I have had fome by eight of the clock: but chiefly is a hot gleam, after that a fhowr, or a dark cloud hath fent them home, but in hot and dry weather it is not fo. The lwarming months are April, May, $\mathcal{F}_{\text {une, and }} \mathcal{F}_{\text {uly; }}$ rarely, though fomerimes in $A$ ug whe

To judge by the time of cheir fwarming, which will phrive, is very uncertain, becaufe of the variable weater that often follows after, for being checked a lictle, and difcouraged at the firt, for a week together, they will fcarce work kindly all the year afeer, fo that many (though lefs, and coming a month afier) not hindred at all byill weather, will bie better than thofe as the end of the year. And anocher caule why forward fwarmes thrive not after foul weather, is, becaufe they are very ventrous abroad, and by the ftormy winds, and unfeafonable weather many are diminifhed, and thereby their increale exceedingly rerarded.

Signes of after fwarms are more manifeft and certain, for aboutien dayes after the firt fwarm is calt, fometimes a litele founer, Cometimes a day or two later, the next Princefs will beginto tune in her treble voyce a mournfu! and begging note, as if Thee did pray her Queen morher to give her leave to bee gone, unto which voyce if the Queen vouchfafe to reply, tuning her bafe to the young Prircels treble, as commonly thee dorh (though fometimes not intreated in a day or two) then thee confents, and the third day after expect a fwarm. The filt day after the grant, how fair foever the weather be, they will not go, and not ordinarily on the next day, except it bee very fair; buton the third day, though it bee fomewhat clole, and cloudy weather, yet fometimes the weather proving very cold and windy, I have known them ftay five or fix dayes after liberry granted.

The evening before they fwarm, the young Princefs goes calling from one part of the Hive to another, fometimes hee is before, fometimes behinde, fometimes above, but ftill calls, and rcting a while between, Ihee ftill renewes her calling. In the morning 
morning before, (hee ofren defcends to the bottome of the Hive, with fhriller and thicker, longer, and more continued notes than at firft, that none may pl ead ignorance, bu: all kno' $N$, and acknowledge, there is a new Princels, and bee ready to artend her when thee takes poffeffion of ber Royalty, dealing berein (but thar thee is her own officer, and it is no difparagement, for the Queen mother is her concinual afliftant) as Prinses on earth that come newly to fucceed in their Dominions, they make it known by found of Trumpets, and Proclamations, in the moft eminent parts of the Kingdome.

But take notice by the way, that fometimes the Commonaly (knowing bett their numbers within, and the flate of the weather abroad) not thinking it go od to make a divifion, will afrer leave obtained, kill the young Princels, and all the infants of the blood Royal, bur this is not ordinary.

If the Queen mocher after a long intreaty be filent, then there is no way buc one, Cnee mutt dye, and all her Allies. As the Mr. Buslero Queens voice is a grane, to her filence is a flut denial: The Proverb here hath no place, Quitacet, confenitire videtur, for without this concent, there is no confene.

Sometimes a chird, nay a fourth will arife after a fecend, if the prime Swarm bee broken; but all (ordinarily) within a fortnight. I have known the lift (but rarely, and in bad wea. ther) (eventeen dayes after the fit ot.

When the fwa:m is up and bufre in their dance, it hath been an old and common practice, for want of other mufrck, to play sthem a fit of Mirth, on a Bafon, Warming-pan, or Kettle, to make them more fpeedily light, and keep them from Aying away, but this (though ordinary) yet is needlels in this refpect, For they will Cettle of themfelves, except they have cholen a place before-hand, which is very near. And then when thers company is all out, they will flye directly thicher, and your ringing and tinging, will prevail nothing to perfwade their Aay.

This benefic there is of ringing, that if you have neighbours tear, you that keep Bees, you may give notice thereby to pre a vent wrangling, if fome of theirs thould rife at the fame sime.

Mr. Ztevits opinion is, That tinging is fo far from prewenting 


\section{A Theatre of Political Flying Infects:}

veriting their $\mathrm{B}_{2}$ ing awny, that it is often a caufe to return the back into their Hive, if not to drive them quite away, for they are amazed as it were, and confounded with the unwonted and clamorous noife.

Mr. Rewriant dnikes ringing before the fwarm bee quire out of their Hive; but sf they be on the wing ready to Hye away, then prefcribes to make the greareft found you can to prevent it, as alfo by throwing up dutt, Hogs-durg, or Cows.dung to difur $b$, and trouble them:

Arifforle doub:ing whecher Bees hear, therefore quettions whecher they rake pleafure in the found becaufe they hear, or for fear, becaufe of the reyerberation, and tremor of the aire?

Clsudian de fext. Confule Honorif.

Mr.Muftet Theatuin Inlector.

Thar the ringing of Bees anciently practifed, was for the former reafon, the Poec implies, faying, The bee-mafter ringing on his $\mathrm{Ba}$ fon by the thrill found, labours to recall the Bees when they are flying away; and Virgil before him, and before him Arifotle, Convocaricas in alveum aimm, they did caufe them to return.

They flye falter or flower, according to the ringing, if hee Arikes apace, they haften away, but if thee bearleafurely, then crey Alye lowly.

But if they will not be ftayed, but hafening on Atill, go beyond your bounds, the accient law of Chriftendome permitteth you 10 purfue them whitherfoever, but cur common $L_{2} w$ is more uncivil, and yeelds no fuch priviledge, for if your Bees bee out of your ground, your property is lolt, if your neighbour bse not more courteous.

Mary directions have been given, to arm them that hive the rwarms to efrape danger, but except they be about the body of a tree, or fetled very high, you may without any cover, or defence fecurely hive them, oherwife get on a paire of Misters, or wollen Gloves on your hands,and a thin Cyprefs over your head and face, and then without any fear, you may fafely vearure a: mone them.

Second fwarms after they are all forth of the Hive, will ufually flye about (before they light) longer than prime fwarms, the realon is, the Bees knowing that mulrirudes beft thrive togecher, and they by the fmalneis of their murmuring found, being privy 
to their pauciry, do by a continued Hying abour, allure as many as they can to come forth to augment their numbers.

Sometimes fwarms will fettle in two or more clufters, a little diftance one from the o:her ( (eldome prime fwarms.) Now ufually the caufe is, becaufe there bee divers Commanders, and each gers a company. Hive the grearelt clufter firt, and fer it down towards the other, then into an unfpleated Hive, Thake down the other, and when they bee all in, knock them down clofe by the firt, and they will go together.

Second fwarms excepe they bee early, and out of large ftocks, feldome thrive alone : Therefore unite two or three sogether, and fo they will bee as good as a firt fwarm; you may do is thus, Having hived that fwarm that you intend to put to another, as foon as it begins to bee dark, cake a far, and laying a couple of ticks onit, fer your firtt hived fwarm on them rowards one end of the fan, and then feich the orher, and between your hands clap the Hive hard on the one fide, holding i: ciofe to the other, molt of the Bees will fall down at the firt clap, but reserate your knocking, and they will all fall down, ard if they enter not prefently, ftir and guide them to the Hive, with a brulh of weeds, and lucin as go any other way, iweep them :o their fellows, and they will all quickly, and quietly afcend. Within an houre or two, you may (for the moft part) fer up the Hive again in his place. I have no: lof forty Baes in upising twenty lwartins, befides the Commanders, which of necelfity mult perifh.

Swarms afeer they bie well letied, feldome return bome again (If you lecthem no: hang too long in the hea:) and the chief caufe of their returning at any sime, is the mifcarriag of the Queen Bee, who cannot well wie her wirgs, baing (perhaps) never torth of the Hive before, and affaying to Aye, tal's befides the ftool, fomerim:s flyes further, but bing quichi'y wea:y falls thore of her company.

Youmay eafily know if it bee thus, for as foon as you liave hived the c'ulter, the firft inquiry they make is for their Leader (whole coming while they hang, they did anziounly expeq) but now being tived, and miffing her, they prefonily dircover it wich a mournful murmuring, rometimes bewayling their condition, jo b thy crying our rogether, and then are a!l fud tenly 
whit and filent, and by and by again renewirg their fad la meateations, cumultuoufly lik ewile running before the Hive, and about the fides thereof, as if they were nor onely difcontented, bue diftracted: Others are fly!ng (but pittifully complaining, as they Alye) about the Garden with a bufie Queft fearching for her; and if they do not in a thort fpace meet with her, will all comfortlefs return to the ftock again, whence they came forth.

But if they firde her, or thee be brought unto therr, they prefently congratulate her return with continued thaking of their wing:, and oral rejoycings, witneffing the ir prefent contentednefs, compiacency, and fatisfaction, making even their joyfull contene $: n$ her, lomeiting more joyfull than before, as if the felt pleafure at her firft return, were more delicious, and ravifhing, by reafon of the fudden change from that difcontent, and diftraction in their lace lofs to an excellency, if not exrafie of delighe and joy.

But if (not finding her) they return home, the next time they come forth, though in numbers a finft lwarm,yet not in the manner of their [warming; for the next Princels comes not forth at the will of the Commons (lofing their Commander,they lofe in this refpeet their liberty) but by petition mut obtain leave of the Queen morher, as in lecond fwarms.

Now when you perceive the Bees difcontented carriage, preo fently seek about (beginning at the ftock, whence they rofe, and going that way, the (warm took) and you Thall undoubtedly finde her, for thee is not alone, but encompalfed with a guard whick will never ftir from her, though they farve in the place: Take her up therefore, removing the Bees that environed her (you may do it lecurely with a little Atick) and carty her to the fwarm. And you cannot but with wonder behold the fuddenalceration, with what a rejoycing plaudise (their mourning being ceafed) do they welcome, and entertainc her; and thofe that were feeking for her abroad (alihough fome rods diftant) are inftantly fenfible of their felicity (by their fellows rejoycing) and haftily securn to exprefs their concene, and bear a part in the general gladnefs.

If a fwarm lighenear the place where another was hived a. day or two before, when you have hived it, fet it ten foor diftant from the place where the other food, for fome Bees of 


\section{A Theatre of Political Flying Infects.}

the firf hived fwarm, will for wo o taree dayes rooether hanker about the place, and if they finde a hive ftanding there, will boldly enter, fuppofing it their own company, and lo milcarry by the others, who take and deal with them as enemies coming to endamage them.

Swarms will the day after they are hived bufily follow their labour, but the removing of them from the place where they were hived, doth not a little difcourage them ; if therefore the weather bee not fair, they will nor tir the firft day, and except it bee more than indifferene, they will not ftir the fecond day, and fo as the foul weather laltech, droop, and grow faint, and fometimes totally milcarry.

To prevent this, the day after they are fet up, when the Sun (hines upon them, or howloever about noon (except it rain) put a litele honey under the hive near the mouth of it, and fome at the mouth, and before the enerance (lefs than a fpoonfull will ferve) which they will quickly fmell, and come down rofeed on, and flye forth, and thereby bee acquainted with their new ftanding, and fall to work upon the firlt fair weather.

If the weacher coninue cold and cloudy a week together: without a litele fupply they will dye, therefore every day refelh them with a litele honey. After they are acquainted with their ftanding, you may put it into the Hive upon a peece of an old comb in the evening. They can indure tour or five dayes without meat, but if the foul weather continue longer, they will hanging by one anothers legs, fall down ta the bottome of the Hive, and perith; but tiy them not too far, bu: quicken them daily with a little honey, and you thall keep them Atrong and lufty ( fuch clofe and windy weather falls ous ofeen in May)you thall gain by this lors, for the weather altering, they will not onely fublitt of themfelves; but by their painful labours, reconipence your colt and care.

If your ftocks caft a fecond fwarm after Midfummer, the belt way is to return it home again. Hive it as you do other fwarms, and about fix of the clock knock them out on a tabie b.fore their ftock, and they will go in, and if they come forth again (as perhaps they will) do lo the fecond time, and if there bee oscafion, the third alio, but look heedfully when you firt 
knock them out for the Queen Bee, and take her away, and then fhaliy ?u bee fure to prevent furcher and fuiture rrouble. And thus thall you keep your ftocks full and lulty, which orberwife were in danger of micartying, and the fwarms (moft years) would bee worth noching.

Sec the pooreft fwarms upon a plank, and when they have done working, dawb them round, allowing air, only through two or three quills and fet them in a drs cold place of your houre, or barr, and lo being lictle lerfible of the al:eration of the air, they wll neep much, and car lictle.

PSintorus Theslur. Arif LII.

Arit? de the to Animil.1 ip c. 19

\section{CHAP. XV.}

\section{What Flumers the Bees gather of.}

7 Thath been almolt generally received, that Bees gather from all forts of flowers, good, and bad, fweet, and bitter; lome a litile, and bur a hatele traiten th s vulgar potition of all kirdes of fluwers, both of Herbs, and Tiees (iarth one) exiepr Dosks and Chectrunnes.

Ariftile curcails this a litile more, and tells us that they gather of all Howers that have colls or fcciets. Mi. Mchff.t thaiens this allo, laying, They refule roflowers, that are tragran: conianed in cells, or lockes; but this allo muth bee natrewed irso thorter bourds, as yer berrg toolarge, for of many 10.ts of tuch flowers, they meddle no: with at all.

Frit, Bees gatber not of flowis which have deep fockers, as Baccielors-buctors, Cuckow-Gowers, Cockicomb, Jaimin Cumphilly, Dead-neite, Wood-bictony, Wrid-blew-teare, Teaz I Red-hony fuchle, rarey, and divers orhers, and yee thele are $m$ ra abundant with hony, than many that the Bees gasher of. And of thele the Humble bies gather plentifully, nature furnithirg them with larger fanos, and longer tongues than she Bees.

2 Urdinarily they gather not of mary litule or fmall flowers, as Rubin, Empernel, scorpioides, Hares-foct, Ohver, Verorica, 8 \&.

3 Nor orcinarity of many phyfical Hexbz, as Erifamorr, Agrimony 
Agrimony, Century, St. Johns-wort, Mugwort, Motherwort, \&c.

4 Not of bitcer Herbs, as Wormwood, Lavender-cotton, Soutkernwood, \&c. yet fometimes of Rue, the flower whereof is farcely bitter.

5 Not of very dry flowers, as Docks, Sorrel, Mercury, Atriplex, Whear, Rye, Oatz, \&rc.

6 No: of thole that have a ftrong ftinking fmell, as Smalledge, Hemlock, Galspíra, Crown-empereal, Cheefrunner, \&sc.

7 Not of thofe that are foporiferous, and Narcotick as Mandrakes, Red-poppy, Night- Thade, Black-briony, \&x.

8 Nor of thofe that are very cold and unctuous, as Orpine, Houl ek, Prick-madam \&cefor all oylie and unctuous things are hurful to them.

9 Nor of thofe that have a frong [weer \{mel], as Feverfew,

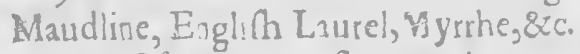

so Of very few flowers that grow in Ponds, or Rivers.

II Not of thofe Alwers, that (though they have greac holluwbodies) thut hard and clofe at the top or lips, as it were, as Toads-Alax, Snap-dragon, Fox-gloves, which the Humblebees will oŗen (being ftronger) and garher of.

12 Not of very double flow:rs, as donble Primrofe, Wallflowers, \&c. cxcepe where the leaves are very fine, as the Dentdelion; nor of fuch as have deep fockers, and have no Arings from the botrome to the top of the flower. Nor of fuch whole Aringz, or horns excend far out of the flower, as Avers, excep: there bie an excrefcency, or cod in the middle of the flower, as Gillow flowers have.

Bes fometimes gather of fuch flowers, as are pernicious and Columel. huttful. The Teil-tree, and the Boxe are very peltilential, fo is alfo the Yew tree.

If they rafte of the flowers of a Corneile-tree, they dye of a fcowring, the blowings of Elmes are difcommended, and wilde plinol. 2 s, Cowcumbers, as allo Woad, which affords a fogoy food that cosz. over-lades the $\mathbf{B} \in e s$, and makes them milcarry in the fields; frow Salc under your Hives, and they will bee the fronger and luttier. Tulipas kill Bees for clofing a little afcernoon, the Bees that are in the $m$ are imprifoned, the fides being out-bywing, and 
Imooth, they cannor get out, and will bee dead, before the next day when they open.

The Lentick rree from whence the Mattick is gathered,

Sands relat. lib.l. affords the bett honey in the world, of which in the ifland $S_{i}$ (arciently Cbios) is great plenty.

Bees gather of the fe flowers following, yer of fome more plen. sifully than of others.

\section{In Marcb.}

Hafel, Willow, Sallow, Enemony, Bunnikin, Daffadil, Violet, Gooleberry, Cornelian, Miffelto, Crocus, Elme, Primrele, Pilewort, Dendelion,Spoonworr, Bears-foot, Black-thorn. Gingle Wall-Alowers, \&Cc.

\section{In April.}

Ale-hoof, Ribes, white, red,black Oak, Peach, March-marigold, Cole, Turnep, Sycomore, or great Maple, Ribwort, Stock gillowflower, Cow-weed, Furfe, Strawberry, Broom, Beans, wilde white Enemony, Bears-ear, Ozier, Plumtree, Cherry, Pear, Apple, Crab, Barbery, Beech, Tear, Maple, Birch, Apricock.

\section{In May:}

Water-crefles, Hull, Angelica, a tall rank grafs ParfnefiOnion, Leek, Garlick-feeds, Dogs-tongue, white Valerian, Tamarisk, Thrifs, Sage, Storksbill, Mouf-ear, Ralpis, Charlock, Marigold, fmall yellow Honyluckle, Poppy, Woodbind, Medlar, blew Valeriar, Burnet, wilde Tanfie, Archangel, both with the white and yellow flowers, called by the Tygurines, Been-fauge, or Bee-fuck, Hawthorn, Elder, white Honyfuckle, King-cup, Peafe, double Gies.

\section{In Frne.}

Tre-trifoly with yellow knops, and another kinde of Trifoly with long red bloffomes, and a Tifoly with pale, yellow bloffomes like a Lotus, bue sanker, Dewbery, Blewbostle, Morhmulleine, Luteola, or Diers weed, white Briony, Savory, Origanum, Hyfop, Pondweed with a flowre like Patience, Lang dez beuf,common Thiftle, Buglols, fometimes, but feldome, Burrage, Parlly, Lotus, Lifinachia, Rofes, red, Damask, Velver, Henbare, Multard-feed Sharewort, Cankerrole, Danefwort, Bindweed, Mallows, Melilot, Calamine, Cowcumber, Thyme, whicb onely yeeldech Nectar. So Mro 
Butler; who therefore findes fault with Virgil, for faying, Mr.But.fem. Crura tbymo plena, but let any obferve, and hee fhall finde they manoc, 6 . gather as ofren Bee-bread as honey; and again hee faith, The Bees gather not of the Rofe, the Primrole, the Clove-Julyflower, the Peare, of all which they gather plentifully, bur nor of the Peafe unsill the bloffome begins to wither, and the cod to put forth, and then they gather Sandaracha of it plentifully, efpecially in the morning.

\section{In Fuly.}

Tobacco, Love, Carduus-benedictus, Jacea, Lamplana, Penny-royal, Small Dentdeliori, Scarler Beans, Mayweed, Gourds, Clorbur, Live-long, Horfe-mints, Skirre:s, Yarrow, Germander, Nip, Sowthittle, fingle, and double July-flowers, Succory, Dill, Clematis Alrera, Fenil, Filius Ante patrem, Holy-hock, French-marigold, Coriander, Lavender, Melon, Blackbery, Buck, Jacobea,Stechados.

$$
\text { In Auguft. }
$$

Red Eye-bright, Knap-weed, Heath, Vir ga Aurea, Ivy.

\section{In September.}

You are to take notice that many of thefe flowers blow twice a year, as Rofemary, Archangel, Tamarisk, Burrage, Charlock alio, although not the fame roo:s. And fome continue longer than the month whereto they are afcribed, and fome begin to blow a little before, but whenfover they blow, the Bees gather of them, but lers in Autumae than in the Spring.

Many flowers afford matter of gathering in the morning before thedew is quite exhaled, which in the hear of the day yeeld little, as the Peale, and a tall rank grafs, having a falk a foot, and a. half loig, with a large bulhie ear.

Bees have this property, that whatfoever Flower they firft begin with, when they goe to work, they meddle with no orher Arit.de hilt. that journey, but lade themfelves with fuch meat alone as that Anim.log c.40 kind yeeldeth; this is a common, but no catholique cultome, for I have often obferved the contrary.

It is true, if there be flowers enough near at hand; to make up their burden of that fort chey begin withall, they will meddle with no other, but if they have begun to gather of a flower that likes them, and cannor finde enough to furnilh them, then they wil make up their load of fome other. 


\section{CHAP. XVI。}

\section{Of the ordering of Bies.}

TN Fetruary life up your Hives on the one fide nimbly, and with a wing wipe awsy all the lharings of combs, drols, dang, or whatfoever elie lyes upon the ftoole, which al:hough tibe Bees in ame would performe, get hereby fhal you fave them a gieat deal of labour.

If gour old Siochs have any ciumbling, or crifpie combs, iske them cur in the Spring, for they canno: work to them; lay tie Hives on ore fide, having ready a fire ct dried Cow. durg in a Chatingdilh without a tlane, the fmoke wil druve the Bees i:ward, and you may fecurely performe it.

Some tell us of putrefaction in the combs, in regard oi dead brood chilled, which combsthey would have taken out; bus I never mer with more shan the Bees could rid themlelves of excepe when the Bees are almolt, if not al:cgecher ftarved.

WFiciserus de

That they tolove quier, tha: they fcarce endure the company fecret, Lib S. of men (is ialle) and therefore mult have walls built abou: therr with holes, to fee what cffends tiem, is ridiculous, yes commended by Florertinis.

Bees are much offended with long hair on head, or asce, lei fuch chercfore as malt be often amorg them wear hort hair, o: be wel covered, on peril of Atinging.

If a Bee have ftung you in ho: weather, your wileft and lafeit way is :o departfor a while, for there iflues with the tirg a ftrong poylorfal favour, which you your lelt may fimel,but how: foever, the Bees wil readily, and hrowing therebs that fome of their company are wrerged, wil with eagernelis leek to vind: ca:e the rijury on whomioever they tirde freien in the flace, and come abour you thick and hrecfold; there is ro way to appeare them but one, ges away as falt as you can, and when the uproar is over, you may lecureig cerre agair.

The bett rime ro doe any thing abour y cur Bees, is, in the mo:ring before they furre, or when chey are newr gone abroad, or in the evening. when they aze recurned trom therr work. 
Dirlwe ibe bony, or celd win:er freeze,

For batb extreams alike annoy the Bies.

Be very careful about the dnore, or entrance into your Hivee, for negligence herein occafions the lofs of more Bies than any 0ther neglect, from the Dor-moufe, ind Tit-moule in 'Winter, and the $W$ afp, and rc bbing Bees in Aurumn.

Lec the doors be fomewhat long, buc very low, not much above the beight of a Bee, and lee them be more or lefs open, according to the leafons; but raiher offend in leaving too narrow an entrance than too large; a thin board in Winter cur in notches like a grate, wel faltned to the Hive, with Cow-dung and $A$ thes rempered togeeher; two notches open in Winter, is enough for a good Hive, one for a poorer; for thereby they are kept more warme in Winter, and more lecure from ene. mies.

When they have wrought a week in the Spring, the better Hives may have three or four notches open, and by degrees more, until they be full, and then you may cake away the grates altogether until Autumne; but be fure to fer them early to the old Stocks that have over-fwarmed, as alfo to the poore fwarms, and in a dry year, fooner than in a moyt, for the Walpes wil be more numerous and early, and the robbing Bees finding litele abroad to bufie themfelves about, will be feeking to plunder poor and weak Stocks betimes.

When you fee the Walpes begin to be bufie, and forfake ea:ing of dead Bees, before the ftooles, venter into the Hives, Cer up your doors to the poorer Stocks, and narrow the paffage of the better with a little Cow-dung (tempered as before) that it may not be above an inch long.

If you will bee at colt, it will be very beneficial to bave a hurdle made of Uziers fet before your Hives, even with your ftools, or elle boards thelving outwards ar the bottome, for the Bees to refton when they come ho me weary and laden.

Mr. Levit millikes the keeping of Hives four or five years at the molt, but his reafons are weak, becaure (faith hee) the combs will be black and unfavoury, and the old Bees are not fo good for increale and breed, as the young, nor fo ftrong and lutty fur labour; but thele realons are without reafon, for blacknefs of the combs is no faul: , as wee thewed before, and 
of the age of Bees, wee fhall treat by and by, orely in a srord, foresthi: they are an annual cieature, and l ve not beyind a year wish the vanage; on the fame ground, therefore ail the cld tocks muft be taken every year.

Many things are receffary for the prefervasion of Bees, frif, A comperency of food which they will labour for, and congats with their ownindut $y$, except the urlearonablenels of the weaster, the fimalnefs of treir cumbers, the ireachery of eremies, the frower of iobbers, or the covecutiels, or limpicity of thei: cwrers by drising them toolate: cratter that by reiserated

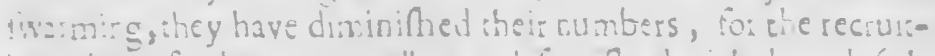
in whereof, they were weil erough birr thed with bicod (a!thughtnen unted,e Nymphs, ye: the topes of coninuance) o: which beirg unimcly bereaved by driving, as defferate, they eithe: fortaherher: Hives; or if they coninue ard work, yet can they not ruficienty breed, and provide thenielyes bepore IT iner, and therefore mutt ftark.

Is hathbeen irquired by lome, what quasity of tory wil ferve a H.ve of Beesall Winter: To which quefion ro cerain a-fwer car be reiumed, becaule of the rumbers which ir icme Hews are nuse, and therefore mutt have more meat; ard alro becaule the Spring in fome years, is more forward than in arothe-, fo tha! quazity that will ferve in ore year, will cos lerve in asciter. Euil wou'd bo: willirgly lei ary ftcck contirue, that bad ro: Five pines a: the leatt of hory.

Scmes asst: will bee corverient to hoift up luch fwarts tha: you fear wili caft, eifecially if Midfummer bee paft, for al. trough they may live : yee crdinarily they will bee weak ard foer, and the Acelt wherce they came lo impover:hed, that if 1. contrues, it will force liwarm the year followir.

Ratestem ap by futirg four Dorrckbats at an equal diftacce under the skirts of the Hive, les them go no further irwards thas the verges, thes dawb them up weli, leaving a Futiog palraçe tor them to go cui of the Hive.

1 like Mir. Sistberns judgement to fet them down again afrerwards, the belt time is in Jotmary. This Mr. Leats laughs at as 2 impcffibility, fufpofing thai they havirg wroughi down to the board, the combs would bee crubled together, acd mary Bees billed; but laying the Hive on the fide, 


\section{A Theatre of Political Flying Injects.}

and making a fmoak (as before) in a cold morning, to driva the Bees up, with a long tharp knife cue the combes a little within the Hive (as I have ofren done) and there will be neither danger, nor damage.

Mr. Butler advifeth to fet them down in the end of Aussif, Mr. Butler when by the death of the old Bees, and alfo of the Drones, Eeia.Mon.c.3. there is more room made, lett their fwarming bee hindred the. next year, unlefs they bee fwarms that have wrought down to the ftool, which indeed mott bave, and then this advice is to litcle purpole.

The courle in our Country which moft take to get fome profi: by their B:es, is driving, out of a foclith pi y they will no: burn them, but care not much to farve shem, and that withour any great profit to them lelves, for they ufually do it after they have calt a iecond fwarm atrout Midfummer, or a week after. The Bess then (befides thore in the brood, which would have been a fufficien fupply to them) being then very few, and many of them old Bees, which in a month, or a little more, will all dye, and then they will bee by much fewer; as foon as they are driven therefore, defpairirg by their ownindultry so fublitt, they will leave the Hive and Aye into another, fo skipping for the molt part,out of the Frying-pan into the fire.lf they work, as fome will endeavour their own prefervation, yer noe one of three in crdinary years out-live the Wincer, and they being weak, are often made a prey to robbers in the Spring, or having fpent their lietle ftore, then Alye away; bur if they our-wrattle all thele difficulties, yet shey will farce fwarm that year.

Moreover litzle hony at that time of the year is ordinarily to bie had; a quart, perhaps a portle, and this is a liberal portion. Whereas if they will drive them, let them do it early before their hony is confumed by fucctifive broods, and let them obferve the condition of the Spring, for thereby they may have fome likelihoods whecher they will do well.

1 have driven ten Hives in the beginning of May (not fwarming the year before) all which after fwarme d the fame Summer, and the prime lwarms did very well: Or if you will drive, take this courfe, when your fock hath calt a lecond fwarm, the night following drive the cid fock in:o the fwarm, and they may do well, except it be late in the year. 


\section{A Theatre of Political Flying Infects.}

Old flocks befoie they hafe fiwarmed, and early firarmes driven, feldome mifcarry; I have known tkem driven swice in shree weets, and full of hony the fecord eime. Nay a t ot:h neighbour of mine drove a fwarm the third time, ard had above a gailon of hony as either of the two frift drivings, and above three quarts the third sime, but it was fo late chas the Bees dyed that Win:er.

If you have a fock tha: lay our the year befere and iwarmed co: , and dorh lo the year following, and Midfummer be patt, drive i:, and ien to one (if the year tee indifferent it siill do meli.)

Nuw to preferve your ftocks, and yet to make fome advantase of your Bees, take this courfe (exceptscuknow a berter, bu: thus I do) Abou: Bertbolcme-tide, I furvey my fwarms, and a' thole that I finde not by the weight compeienty fupplied, ramely with fue pintes of hony ai the leatt. I take, and I $E x$ amice my old ftocks, efpecially luch as have fwarmed ewwice, or ofmer, and where I ficde few Bees, which you hail lnow, if givirg the Hive a licte knock with your finger $c n$ the out-fide of the Hive, if the murmur bee ludden and thor, then it is figne there bee bu: few Bees, but if it beefmart and long, de.cending from the top downards, then is is a rope af Elenty.

They tha: have bat few Bees, though they bee never fo well ftored with hory, get will nor continue over the nex: Spring, bu: wil' bee a prey to robbers; therefore it is betrer to alie them sien io loie them, and their horey allo; bus yet if you deture to fave ary that are well lupplied, then drive a lwarm tiat you incend so a tre into them, and fo lhall you have a grod lteck; and thes with Gods bieling frali you ircicale your Bees, and have a luficiency of hory ard wax. It you have no: you may rase as many of the bet as you hall thint convenien:

Some prefcribe to tabe thole that are toofull of hony, as (thereby) ditabled co breed, ard profper the year tollowire. bui this is but a groundiels luppotrion for oughi ever I cou'd fiode, having had as good as anj ocher, the corabes being generally filled with hory to the baard, which I have let liard on purpole to try whether they would breed, and never found, bus ijst wers as full of Bees the yearfollowing, as any orher; for 


\section{A T beatre of Political Flying Infects.}

afier working time there is a long rime of eating, and if they be numerous with Bees, they wil make roome enough by breeding time.

The manner in a word to take Hives in the latter part of the year is by burning, which briefly you may thus doe; take an old linnen cloath and cut it into long narrow peeces, about two haadfuls long, and halfe an inch broad, and then having meleed beaten Brimftone, dip them therein, and having digged a hole near the Hive thar you intend to take, let it be fomewhat more than a foot over, and half as deep; fet in the bottome of it. two or three crotched ficks, into which put three or four of your raggs fmeared with Brimltone, and having kindled them fet the Hive over, Atopping the verges fomewhat ciole, and your Bees with the Imoak wil in a lhort fpace fall down ftifled and dead.

For the manner of driving, it is needlefs that I thould fpeak much, being wel known almolt to every one.

Have a prepared Hive as near as you can, of the breadth, in the skirt, of that Hive you will drive fetring it on the ground, put heet over it, and wel faften it with a ftrong pack-threadround abour the Hive within an inch of the skirts, then having a Trivert, Payl, or Firkin read , ,er the empey Hive therein with the mouth upwards, and then life the Hive you wil drive, nimbly from the Atall, and fer it upon them empry, and gather up quickly the theet that hangs down to the crown, and taften it wel likewile with a little line, about an inch from the skirt, and turn them thustied together, that the empey Hive may ftand upwards, and knock gently wieh the palnes of your hands on the fides, and on the crown, fomerimes in one place, and then in anather, and often paufe, and make a litile ftop, that the Bees may alcend, and reiterate your clapping agane; in half an hour they. wil bs all, or the molt of them gone up, and then carty it to the place where the other ftood; if you doe 10 in the evenirg, lecis ftand unmeddled with ali night; if in the morning, let it be berore Sun; and if there be any Bees behind, when ycu take out the combs, fweep them off with a wing, aid they wil hince their fitlows.

Many in the Bees neceffry commend and applaud feeding, when by driving unfeafonably, oi not feafonably uniting ( as the 
Proverb is ) T bey bave broken ikcir hoseds, tiej would gie's them eflaifler, bu: for she molt part:00 rarrow and licaniy for the fore.

For feeding of weak Bees, many things by maty are prefcri: bed, I hal be briet in the particulars, becaufe I airogether diflike feeding, excep: in the beginning of the year, through the backwardnels of the Spring, lome Hives (otherwile iuficiertly furaihed) ltand in seed, or fome carly (warmes, the weather proviro rempeltuous, celd, or clole, fometimes for abore a week sogether: it wil be very consenient then so relieve them, unsil the weather alter, and they begin co work, when they wil reed no longer your fupply, and without a litele [upply would bee fo poor and feeble, that they would untimely micarry, and dje.

The anciens commend feeding of them with Raifres, bruiled Figos; Pliny bids fet Hens flelh before:tiem, although he acknowledgeth that they eace no kinde of fielh, and therefore in that reffee preferres them before the Horner, and the Waipe.

The Genieman tba: wro:e the firtt lsrge Lereer in Mafter Mr. Hartibs Hettlits Legacy, a wel-w:Sher to Bees, alchough lietle skilled, Legiog (as it appears by his Projects) in the nature or oiderirg of them, axech a general deficiency in this Kinodome in this refpet, as if we were more negligen, or ignorant than fome of o. ther Couniriss; for the glery ctour Nation let me pleas (with he igromantly traduceth)

The knowledge of Bees was rever truly communica:ed to the Forid by any but by Englifs men; Mr. Sintberme brake the ice, thenfollowed Maftes Livit, who wroie more than fify years firce: though he was publithed lorg after Mr, B*:ler: Mr. Levit, I lay, noc the Father of the publiner, but the Grarde father (pertaps his Grand-child krew rot fo much) ard I quefton nor bu: Nis Bx:ir was acquainied witb his Eook, for i: was in d vers meas hands though no: prined.

Afer tim Ml, Bk:lit wrute figgulaty wel (although in fome thirgs detective, and no queftion but ifier Ages may adde mere, bu: I wil not be too bater, not deubting of the Gentimars gaed meaning; bue advite hir, ard all otters in this, or a:y other lutjec, no: to urge Eutopian conceis: bur luchetirg 


\section{A Theatre of Political Flying Infects.}

as out of experience they have fome probable grounds for, $\mathrm{Ne}$ futor ultra crepidam, all Countries produce not an equal ftore of every commodity; that other Countries abound more with Hony, is no: becrule they abound in skil, Scandia is more plen:iful, becaule after the great fnowes tha: lye all Winter on the ground, and keep it warme, which once diffolved, the earth is prefentiy embroidered with a garment of Flowers in greater plensy, variety, and continuance than molt Countries afford; and the long dayes are another advanage, elpecially the weather no: being fo variable as with us, and a $p$ incipal caufe of their increale is the extreame cold in Winter, which holds them in a perpetual fleep, fo tha: they eate little after they leave working, and the earth with the Winters Snow and Raine is thorowly moyftned, that drought feldome proves injurious to them, as is is often with us.

But for his conceits of feeding Bees with fweer compofrions of divers things befides Hony, becaufe cheaper; we are to know, that alchough they wil ease of all kinds of fweet things, yet are they not fo proper and natural as Hony, neither wil thoy when they Atand in need of teeding extrast Hony out of them, as hee fuppofech, and reflenifh their Combs, no nor carry at fuch times Hony which they feed on into their Combs; and when they can doe this, namely, when they are lutty, and the weather warme, they ra:her gather it abroad ( and fave your colt and charges) but fuppole thofe compofitions were beneficial, yet nos co the old Stosks that are likely to mifcarty, for they for the moft part have already more meat than mouches, but get it might preferve the fwarmer.

I have thewed a cheaper and fafer way, by uniting, and for cafual wants, in regard of the continuance of cold and bad weather, Hony is more natural.

And whereas Mr. Soktberne objects againft old Hony, that it wil make them fcoure, this is but a fancy, I yearly upon occa fi: ons experiment it, bus never found shat inconvenience.

Heobjects further, If they be fed, they wil fall co robbing of orhers, but herein allo he was mittaken; Bees that Atand in need of feeding are feldome fo lufty, never fo ventrous to plunder others, but rather in continual danger to be robbed by others of shat little they have, which feeding, not duly performed, readily expoleth them unto.

The 
The Gendeman in Mr. Harllibs Le gacy, defiresh to fare the poor iwarmes by feeding, and with the lealt charges that might be, whereas no: one of fix (never fo carefully fed) that are deiperacely poor, can be preferved, and if they doe live and ckicape the robbers, and no: forlake their Hives, which molt of them wil doe, finding their numbers finsll, yee will they not livarme if they live out the Summer, fo that the charges befides the trouble will double the profi:。

When you have occalion to feed, if you have not referved Combs on purpore when you rook your Bees, ipread Hony upon 2 dry combe, and pu: it under the Hive in the evening, but remember to take it awsy in the morrinc, if any be left, or thut them up unil they have eaten all, leaft ibe robbing Bees finde it, and not contented therewith, carry away alfo that lutele they have in the combes, I would have feeding begun ( where it is neceffary) before an ablo.ure wane, lealt they bee fo poor and weak that they cannot come down; if any happen fo to be, then turne up the mouth of the H.ve in the hear of the SuD, or near 2 Fire, and drop a hicle liquid hony among them.

1 have recovered lwarmes thut in by long cold weather, where not a Bee hat been able to ftirre, and continung it after with a litsle hony pot under the Hive until the chirge of the weather, they have done very wel that ytar.

Bees will iometimes lick the fweetnefs of rotten Pears, fometimes full ripe Grapes, but yet a very few among a great many with us.

Facnellus de

seb. Siculisslir. suior.decad.

Io Sicilia there be Grapes of which they make Muskacell, which are therefore called the Bee-grape,becaufe the Bees greedily feed upon them, as allo Fues.

Mr. Butier counfels, that you cur afunder fuch Stocks as you incend to preterve (almolt even with the Bees) If they have nos wrough: within a handful of the ftoole, ard then to let them dowas making them a new door, ha: thus shey may be warmer is the win:er.

This is a coure both wafful and vielefs, for I rever bad any Zock, if it were fupplied with meat, thas milcarried, al hough she Bees had no: wroughe half way down. And to prevent ir, in o:dina:y years fic your Hives according to the greatrels or fmalnets of your fwarms; This way, if orherwile profiable, cannot 
be performed without deftruetion of your Hives, and the lofs and crouble of your Bees, and the Stock wil be fo fmall, that excepi you adde anocher, and raife $i r_{\text {, the fwarme wil be wor.h }}$ nothing.

To prevent the cold, daub up the skirrs round, and let the entrance be very fonall.

A watering place near your Bee-gardea is very neceffary, they cannot fubfilt wishout it.
But near pure Cbryftal Springs,
Green moffie Forntaines ftill your Bec-bives place,
Virgil.
And fre ams that glide aloag the verdant graffe.

Withour it fome fay, they can neither make their Combes, nor yet their Hony ; but the ure is not fo generall, but when they feed on Bee-bread ( which is hor and dry ) they cannor bre withour it, and they love nos to goe farre for it.

Into your running or ftanding water many prefcribe to calt in Atones, fomewhar elevated above the water:

- Into the Poole, whet ber it fand or flow,

Great fromes a croffe, and Willow brancloes tbrow,

Virgil.

As Bridges for the Bees to ftand upon, And/pread their wings agaixst tbe Swanmers Sun.

But peeces of Wood, or Boards, entred into the water, and fet thelving, or leaning towards the North are much better, the ftones being too cold in the fpring; but if you can bare the banks of the North-fide of your Pond of all buthes, and graffe Theiving towards the water, where they may drink uncer the Wind, and in the heat of the Sun, and fuck it our of the earth above the water, which they rather defire, than to fuck the pure water it felf.

But if you have neither Pond, nor River within wenty rodds of your Bee-garden, fet water in woocien troughs in your Garden, and have lighe thin moveable boards, or corks within your rFoughs, thar may rife and fall with the water, ler them have fmall clefrs, or many litele holes bored thrcugh them, that the Rees may ltand on the boards and drink ; keep Hens and Chick - 
ens, efpecially Ducklings from thefe troughs, for they will de. Atroy your Bees.

AMr. Bwiler enumerating the feveral actions of Bees in warme dayes in Winter, among oihers faith, they drink, but he was deceired, for although foinetimes in Fanwary they gather a lietle Bee-bread, yec uncil they plentifully feed of it, they drink not, for while they feed on Neetar which is hor and moyller than Bee-bread, they need it not, but the other being more bot and dry, makes them exceedirig thirfy.

Bees will be very much about tinks, and where greafre water is thrown, nay they rather delight to drink out of Sawpits and holes where the water is thick and troubled, than out of Ponds, though nearer them; and when they wacer out of Ponds, they delight (as I faid) to extract the water from the moy ftoed. earth near the Ponds, or Pivers brinkes, than to fuck or drink of the purer water it felf, which yet fome will.

Mr. Remnant luppofth, that they fuck out of finkes, or old di ches, and places that incline to Salt-pecer, for want of falt water, wherewith faith he they feafon their Hony, which! beleeve not, but rather that they may be more vigorous and lufy, and therefore fale is preferibed to be laid under weak Stocks; hee faith, it is in the defeet of Salt water, but where they are niar the Salt they ufe it:

And he further faith, they feafon the ir Hony with falt water, and in the want of it, with brackith water thus extracted, therefore he commends the feeting of falt water or brine near them; bet they neither ufe falc water about their Hony, nor yet freth, ( as Cofume $D_{a}$ ) but for the reafon befure mertioned,

In Summer they wil drink fecurely upon the Duck-lheard, and other thick weedes in the middle of Ponds; the beft time to. emcre Bees, if you are to carry them farre is in the end of Iaruary, alichough if you be necelfitated, you may do it well enough prefently after Mirbaelmas.

A lietle before you take them from their ftanding, life up a lictle the skirts of the Hive, and pur three or four Tile-Theards under the Verges, that ( the Hives Aanding fomewhat above the board) all the Bees may afcend, otherwile fome wil be left on the borsome of the foole, which will be loft; then fpread a Beetupon the ground betore it, and nimbly take it off, and fec it 


\section{A Theatre of Political Flying Infects.}

upon the middle of the theet, and gathering it up round, tye it clole above the crown with a noole, tye it alfo about the middle with a Pacla-chred, then put a Cool Aaffe through the noole (bee fure it bee well tyed) it mult bang perpendicular, not (waying one way, or other. Let it bee carried between two to the place whither you intend it, when you come there, let it down, but open it not prefently, for the Bees will bee fomewhat difturbed with the motion, and ready to flye forth; it is beft to fet it up in the heat of the day, that if any fuddenly flye forth, they may no: bee chilled with the cold, but after a little flying about, they may return to it again; but if the weacher bee clofe and Atill, then fer it up in the evening, and ftop it up clofe (leaving breathing holes ) uncill a faire day, and then open the door.

\section{CHAP. X VIr. \\ Of Bees breathing.}

A Pter a long condefcenfion to the capacities of the Vulgar, A to whom almolt peculiarly this large pratical Difcourfe appertains: I will now endeavour to fer an edge upon, if not, to fatisfie the appetites of the more judicious, though not with a banquet of Rarities, yec with a dith or two of Sweet-meats (according to promife) as foon as I can provide them.

There is a neceffity of refrigeration from withour, by aire Arifode pure or water. Now the grand inquiry is, How Infects (in particular tibus Animal. Bees) are refrigerated. The Philofophers before Arifiotle, held I. z.c.6. that all creatures breached, as Democritm, Diogenes, Amaxan Arifode Spirat. goras.

Pliny profeffech that hee accords no: with Ariftotle in this particulas, that Fither breathed not, becaufe they did hear Plin Nacubit? and fmell. 1.9.6 7 .

I will rpeak one word to this (alchough our of my fphere) and but a word, lelt I conjure up learned Scalagers ghot to oppole mee, That Fithes breath is evident to lenie, I have feen them often come up to the top of the waier, and a litele elevating cheir heads above, draw is in with the water, and with 
many bubbles recurn it again, fome at the Gills, but the greater part at the mouth.

And that they cannot live without aire, thus, In great Frofts they cannot long continue though they have water, except the Ice bee broken, and then they will prefently come to the hole for aire, fo that fomerimes you may take them out with your hands. And if it be fome dayes delayed, they will turn up their bellies in the holes as quite fpent, yet by the benefit of the aire, many of them recover, but if it bee altogerher neglected, in a grear Froft moft Pond- filh will dye.

Rondeletius holds, That not onely Fithes, but Infeets alfo

Rondel. de piretur l. 4 .

Cardarode Subtil.1.12. bieath (although without lungs) in particular Bees, becaufe of the found, and murmure that they make, and tecaule they fmell.

Cardan affirms, That all living creatures breath either openly or fecredy, manifeftly fuch as have lungs, more hiddenly which have gills; and that is meft obfcure by palpitarion, and therefore whereas Ariftolle denies fuch creatures that have no lungs to breache, hee underftands thereby a perfect breaching, and therelore faith, The found of Bees is caufed by the aire, which they receive and draw in; why not che fame inftrument that draws it in recuin it? But this opinion, alchough Ariftorlt's $S$ caliger labours to undermine, but to little purpofe. Hee fup. pefeth it to bee caufed by the Thaking of their wings. This both Ar.folle, and $H_{1}$, gibius betore him propounded, but did not conciude of; Mr. Muffet faith, It is a fecret not to bee determined of. The L. Virulam fuppofeth the humming found of I.Verul glva- Bees (which is an un qual buzzing) to bee from the motion of fivar.cene. 2. their wings, becaufs it is noi heard, but when they fir, I deny 375. nos bucthe found is more frrill and audsble thereby, but nos onely caufed there with.

Firft, bicaufe in a Hive fu'l of Bees, where they lye crowded up thick togecher in the Winter between the combs, without room to dilate their wings, not ar all to Thake them, you thall have a fudden fmart frund in an inftane from the place touched, defcending to the bottome fromail the Bees, as it were complaining.

Secund!y, by the inc urag mene of the Queen Bee, when wul harms are units d, and lo ming cd togecter, that either of them 


\section{A 7 beatre of Political Flying Injects.}

them being encompaffed with their whole troop, and having no room to Atir, and thake their wings (being each of them in the center of their regiment) but as they are in the conflict moved with the whole body; yet may they bee heard audibly fametimes a rod from the ilive a great while cogether, without incermilfion, each encouraging her army to ltand to her, and for ber.

Thirdiy, If their found were caufed by the agitation of their wings only, it could not bee various and changed, but onely fmaller, or greacer, bur both Ariftotle and scaliger acknowledge, that they change their voyce; and if they did not, yet Arift de hift. is it fo evident to fenfe, that but coming among them, by their $19.640_{0}$ different voyces, it may bee known whether they mourn or rejoyce, work or fight.

Fourthly, If their found were caufed by the agitation of their wings, then according to the largenefs of their wings fhould bee the greatnels of their found, but this is not So; $_{\text {; the Queen }}$ Bees wings are no bigger than a common Bees, but her found is more than ten times lowder and greater.

I might adde that Crickets fing, and their voyces are heard very far, and yer have no wings to thake; nay they move nor their bodies when they fing, as I have often obferved, and as foon as they ftir, they give over finging.

In a word, as to a Mufitian that playes on a Fiuse, o: fuch like Wind-inftrurnent, there is required skitfulnefs in the outward couch of his inftrument, and alfo wind to bee infpired, without which hee cannot poffibly frike the ear, or pleale the fenfe with any melodious noife, fo do I conceive in forma refpects the humming noife of the Bees, is caufed both by the ourward mocion of their wings, and alfo by an inward motion, that I lay, not infpiration.

Ariftotle was very wavering what to determide concerning their found, fometimes hee faith, they make a noife; fomet mes, hee grants they have a voice, and hee haih no fooner granted ir, but would fain bite it in again if hee could, as overthrowing this Arift.de bift pofition, that they breathe not; Hear what hee faith, they change $1 \cdot 9$, 9.40 . their voyce, when they fwarm they have a proper and peculiar voyce, but wherber they have a voyce or nor, is not yee through. Iy underftood in regard of the difficuliy. 
Thus is this grand Philofopher unrefolved, it is a difficulty; hee cannot tell what to decermine ; but hee hath taken up another opinion, and although hee bee fomewhat convinced of the vanity of it, yec hee is loath to retract, hee will rather fer his wit upon the Teners, and feign fome new diftinction, fomerimes they make a found, fomerimes they have a voyce.

Arift de Spiras. Small and blood-tefs creatures are externally cooled by the ambient aire, or water, neicher is it neceffary that the air fhould penetrate them, becaule of the weaknefs of their natural heat; but the coldeft creatures need refrigeration, for they have a heart, as the Snail, which is vifible to all men upon diffeetion, and much more hot creacures, as Beesare, which have allo a heart, although it bee not eafily diferned by prejudicate eyes.

Winged creatures when they move themfelves by the attriArift. de Som. no \& Vigil. Aritt.debits. 1.4 c.7. tion of the aire fliding into their belly, make a noife.

And again, Infeets have no voyce, but make a found onely by the admiffion of the aire, not emiffion, and Bees, and all other Infeets life themfelves up with their wings, and prefenily contraet themfelves when there is made a found by the atcrition of the aire taken in, but not conftant to himlelf, hee faith in ano ther Arift.de Sçirate place, There is an innate implanted aire in the tranfverfe inclofure, which being lifted up, and contracted, caufech thereby a fmiting on the little membrane, and hence fatth hee is their Cound.

Scal'g.com. in Scaliger faith, It is from a membrane including the aire, and Arift.de bit. the motion of the external members.

l. 4 c.7.

Magirus Pty. frol.

L.Verul, Silva Sil. cent.2.133

Mogir us faith. Their noife is not made by a recurn of the aire, but by an agitation of an inward not"outward aire.

Another fuppofechfounds, and therefore voyces may bee made without aire. It is certain, faith hee, howfoever it crols the received opinion, that lounds bee creaced without aire, though aire bee the moft favourable deferene of founds. Take a veflel of water, and knapa pair of congs fome depth within the water, and you thall hear the found of the tongs well enough, and not much diminif ed, and yet there is no aire as ail prelent. What if I hould fay there is aire in the water, becaufe there is in it a found made?

Aris.de Spirat.

Hot creatures as Bees, dofare a greater refrigeration : Bees like 


\section{A Theatre of Political Flying Infects.}

like to thole creatures tha: breathe, do make a found (piritu) with the aire or (pirit, for when the native, which is (as before) implaneed in the tranfverle enclofure, is lifred up and contracted, then is caufed an attrition of the membrane ; For they do not otherwile move this part, then o.her Animals draw aire with their lungs from without, and Fifhes by the agitation of their Gills.

Scaliger is for tranfpiration; and fo Bafs., hee faith, That $B_{3}$ fil Heram. Infects brearhe not, being without lungs, ba were nourithed Honil.s. by aire in the excerval parts, and his realon is, if they bee dipt or fmeared with oyl, they prefently dye, the paffages or pores boing ltopt, but yee laith hee, If they bee prelene'y walhed Alexind. with water (others fay Vinegar) the paffiges beirg opened, Aphrodis.t. I. they will live; and with him accord divers others.

To this I anfwer, That it is granted that oyl kills Bees, and almoft all other Infeets being nacurally mortal ts them, and wath them afeer with what you will they will, neither revive, nor recover, but almolt as luddenly' dye (though but a part of their body bee (ineared with oyl) os if they were calt on hor embers. And that it is not, becaule of the ftopping of the paffages of the aire, appears thus : Let Bees bee drowned in honey, which is. more vifcous and clammy than oyl, yet if they bee timely taken out, they will dry themfelves, or bee fuckt dry by their fellows, and recover.

Now at laft you cannot but take noice how various they are. in their opinions, that deny breathing to Bees, cr fo to make a norfe, they cannot but acknowledge a necefficy of refrigeracion.

Arifotle fometimes by the admiffron, not emiffion of aire; fometimes by a native implanted aire.

Scoliger from a membrane including the aire, and the motion of the excernal members.

Mogirus by an agiration of an inward aire onely, but whether na:ive, or adventicious, hee expreffeth not.

L. Verulam fometimes, that a found may bee made withous aire, fometimes by the morion of the ir wing:

$B$ afil that they are cooled by tranfpiration, and there core by an aire fo admitred, mult make their noife. Thus willully deviating from, and denying a truth, they are quickly be-wildred in a thicket of exrors.

Now 
Aldrovand, prolegcm. in lib.de is rectis.

Arith. de Spir.

Now let us hear their arguments why they fuppole them not to breach, Aldrovandas laich, Infects, neither breathe, nor need breathing, becaufe a breathing faculcy is beftowed on creatures which have lungs, but Infeets being blood-lefs are cold, and therefore want nut refrigeration, but are fufficiently cooled by a native aire, or excernally by tranípiration; I anfwer many of them (if any) ate not blood-lers, for they have a heart which the Philofopher accounts the original of bloed. And if they have a heart (Aldrovand. acknowledgech) they have lungs allo, and tand in need of great refrigeration. And that Bees are hot creatures, Ariffolle affirms.

Secondly, If they breathed, as they drew in breath, they muft alfo return it, which could rot bee done bur by fome inward inArument; but all Infects are without bowels (according to Ariftorle) but this is manifertly untrue; diffect a large Grafn hopfer, the bowels are vifible to him that hath bat half an eye; and fo alfo in Humble-bees, and in many orher Infeets.

In fome that are very fmall, they are not diftinclly vifible; but it follows not therefore that they are without them, no more than becaufe they want the vifible organs of hearing and fmelling, that therefore they neither hear, nor fmell; both which fenfes almot all natures fecretaries acknowledge to bee in them. And yet who is able to point out the inftruments. Aldreverd. batb fome other reafon, but all buil on the former foundation, which $\mathrm{mi}$ icarrying, they mult needs go to the ground.

Sealo de fubtis,

Scaliger his main aroument that they breathe not, is, becaule exercitat.273. they need no: a refrigeration of cheir heat having no heart; but this being manileft to fenfe, as learned Dr. Harvey avers, the asgument talls to the ground.

Others deny that infects breathe, and their reafon is, becaule there is no brearhing knot,or turning in the inward intrall, that is to fay a membrane lixe to the lungs, whereby the aire is drawn in, and therefore fome hold that they live as plants; but there is a great difference whether any thing breathes or lives. Others convinced of the vanity of this conceit, hold that they have fomething analogous, namely by tranfpiration. Ariftetle faith Bees breathe not, becaufe they continue long
Arit. de Spir. in the water. But not long under the water; fo long as by beaving wish their wings, they keep their heads out, they fre- 
ferve themfelves; but their wings being once shorough wee, they quickly drown.

And that they receive water into their bodies, appears, becaufe when they dye fuffocared in the water, they are greater than when they are alive, whereas if they dye otherwile, they hrink up, and are lefs.

Ariff ttle, and alfo Scaliger, adde another reafon, they will, Idem despicovered with alhes revive, perhaps if they have not been rat.

long drowned, with heat they will recover, as they will if they bee chilled near twency hours, but alhes are fo far from reviving of them, that if they bee alive and lufty, they would rather kill them; for duft (much more afhes) will, if they go a lictle upon it, fo fur their dew-claved feet, that it will indifpure them to flye.

Breathing, faith Scaliger is feen by motion, or perceived by Scalig. de fubtouch, by the pulfe, or underftood by the voyce, and all the:e til exercitat. wayes more or lets, may it appear that Bees breache.

But it may bee objected, that they have no noltils to receive breath by.

I anfwer, They breathe by their mouth, Arifotle laith, th: mouth $\mathrm{i}$; for many ufes, for divers creatures do brearhe with it. For breashing is not a proper work of the noftrils, bur creacures breathe part y by the noftrils, partly bu the mouth.

But is is furcher objected, wee iee nolunga: I anfwer, in 273. fowls the lungs arefmall, and but like 2 merabrane; furely then in fuch Ima. / Ay ing cieatures as Bees, they are noc viible.

But to conclude they have no lungs, becaule wee lee non:, arif de partiwere bur a weak arguing. In fome creatures denied to breathe, we bus Animal. fee them, and perhaps wich a good muleiplying glais, might fee l.4.c 0. in thele; by the fame rea fon wee mighe deny they hear or fimell, becaule wee fee no organs (as before) whereby chey perform it, and yer nothing is more certain.

That Bees breathe, Mr. Butler affirms, but it was a queftion Butler Fem. hee difpured not, but relating how af:er they have been dead a Mon.c.\%. whole day (being chilled wi.h cold) al though, laith hee, they be quite dead, without ienfe, motion, and breath, you may, if you bee difpoled, revive them with the warmth of your hand (but look to your felves, for miny when they bejin to rev.ve, will ingrattfully fting.) And this their seviving cannot but aiAr ta. de parribus Animal. .3 cols. A cut de Spis. 
mof leem a miracle unto you, for prefently their fpirits returtuing, you fhall fee them beginto pant and breathe, and anon they will flye away as lufiy as the bet?.

Bur to come ro a gumenis, That Bees breathe is evident by their paning ard palpiation; I mean not when they are in the coudition of pirfoners, and violently held or decained, for wich Scal.ger I acknowledge, thai Bees or Ayes captivaced, palpirarion is nor breathing. bur a Ar ving to efcape.

Bies when they re:urn frem their work are often fo weary (as meo cut of briat) that they are necefitated to reft thems folves near the $\mathrm{H}$ ve, untill they have recolleaed their fpirits, and gorter, by a litele reft, new frength, at firft panting more qu'ck and lhort, but by and by fieching as it were a longer b.e.th, une li a: latt shey pane lirele, if ar all.

Second: It appeurs by their fwea:ing at the Hive door, a moitt va our is vifible as the door of a good Hive in the morning, fomerimes in drops of water. As B ars in Rufsia, while they llecp in Winter, yer are found by the Hunters by she diffolved frow eurned ino if under wisch they ly., caufed by their continued breaching.

Thidly, becaufe if a full Hive boe clofe fnut up that no aire eaiers, :ley will quistly beefuffocared and $d$, $e_{\text {; }}$ whereas indeed if trere be but $f(w)$ Eees, they will continue the longer enciofed, a circurn-smbien aire in the mean time refrigerating, and cootirg chem.

F lrtily, if you Atop their throats, Ariffotle acknowle geth they will bee it argl d.

Fifthly, whenshey are chilled with cold, lay them in the warm Sun, or near a fire, or it you dare venture, hold them in your hand, ard you fhall fee them begin filt a litje to tir, then to pan, a d the !orger more ltiongly, uavill they remit is by degiees as they recover life.

Bu: I co he out the sime to prove by arguments to the ear, a thing lo v lible to the eye. Hold; our hand ncar to the moush of a jull Hive, and that in : he right when they are fuppoicd to Acep, and notio hir, ard you Thall fecla cool aire come from them, Nay hold a festh $r$, and you thall lee it Atr to and fro, as if is. would be blown away, 


\section{A Theatre of Politica! Flying Inferts.}

Som a afi:m, that infects have noblood, ticule they have no heart norl ver. Pliky was ofop.nion, that thuugh the y had noblood, yet lomewhar analogou: or equivalent, for wha foeyer is the vital humor, is its bf od. Learned Dector Haryy in his Gr Hur. exeranatomical lectures, openly affirmed, that itres have a heart, citaidatum. (I heard him) which alio hee hath lince publithed, although Dr. Primrofe will farce acknowledge i:, prceending his weak eye. fight, but this being affart:d and confirmed by fuch undeniable experience, 1 readily fublcribe they have a terrt, and therefore a liver, and cherefore biood, for the heart is the fourtain of blood, and hath filt biood, and Creatures which have ani l. 3.6. 4. blood have a liver.

Aldrovandus cieing Arifotl: faith, all creatu:es have both a hearc and alfo a liver, one for the Original of hear, and the o. ther for the concocting of their mext, And again citing Aristothe de partibus animalium lib. 3 . hee hach thefe words; corde chrens nulum animalurquam ortum eft. No Creacure was ever produced without 2 heart: arid there is good reafon for this affertion, feeing the heart in Ariftotles judgement is the Orio ginal oflife, hear, blood, fenfe, and motion, and nature doth fuppeditate breathing or refrigeratson for the benefit or coolm ing of the heat in the heart,

AttCreatures which have blood have a heart, and why not, all Creatures which have a hearc have blood? but in little crea- A sift.de hifto tures the blood is fo ob:cure, that 15 canno: bee feen as in animal.jib. greater, but onely in the heart (not alwaies there) becaufe of crio. the thinneffe of the blood and the veins, are fo hutte and imall, that they can farce if at all bee perceived, but the heart is the beginning of the veins, and the Original, and fumizain of blood, and (as hee faith) the beginning of fenfe, for living creasures have the beginning of ienfe, where they have the beginning of motiun.

But yer notwithfanding all this, the liver and the heart is fo farrefiom boing the suthor and foun:ain of blood (wh ch yer $A-$ Arit, de fombo er Vigil,

Aldrov. prolegon. is lib.denteftiso riffolli, and all Phyfrians affirm) that the contrary planiy ap- mal. (atersisat pears in the fabr ck of the Chacken in the eog: namely, that the su. blood is the mother of the hears and the liv:s, which Pnyfirians feen ro confeffe unawares, when they derermine the Parcnchyo ma uf the Liver to bee a certain flo wing of blood, as if noining 
Idem in eod. elfe were there but coagulated blood, and that the heart (faith lib.exarcitat, hee) is not the au.hor of blood,appears, becaufe his fubftance or parenchyms is produced, fomerimes afser the blood, and is Cuperadded to the beatiog veficles.

Now leeing is is fo apparent that Bees have 2 heart, then it mult fullew neceffarly, that they mutt have lings alfo ( which Aldrovandw grants) that thele receiving and returning alle may refrigerate the heart, now the lungs receive the Original of thesi morion from the heasi, and with his fulneffe and en.ptinefs as it is coneraqted and cnlarged, makes way for the egrelle or ingreffe of air, when it is lified up, the air comes in, and when it is contracted it goeth forth.

Ariftde Spi- That fome infects have lungs, Arifolle doch implicitely ras. grari, for hee faith, pintmones bab:ni que in lusim feium jam

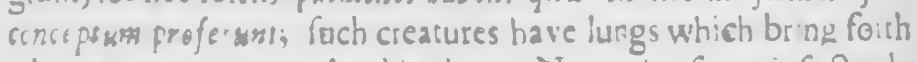
a living crearure co-ceived in them. Now that fome infects do fo, is undeniable. Scaliger aftirms is of a cercain fort of Ale, of scalig.defst. wh ch weef frake befoe, and it Tha'l bre furtter confirmed by a iis exercisat. difccurfe of the claw-:ailed humble Bee, when wee lpeak of Humbie Bees.

\section{CHA P. YVIII.}

\section{of Bies lomperatere, Sleep, $A_{0} e_{0}$}

Nicol.us Leonic, sin qua?tu n. na: tural. 43

A:drovan. pril gem in

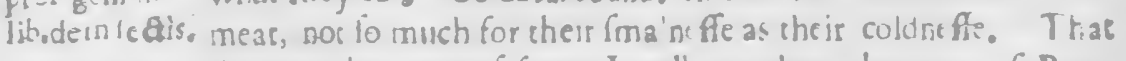
Arifto.de ?pio part. th s may bee true of fome I w ll not deny, but not of Bees, they are hot c'ez ures, and defire much refiefhing, and quickly digelt wnat ihey ear. I, deed he, ar-very liberal feeders; whiofoever inal, uberve the abundarce of Bie-bitad that is daily brougbe nits a good hile, which they fpend amoft as faft as shey 


\section{A T beatre of Political Flying Injects.}

they get (befides honey) and alfo confiders, how much they eat abroad when they gather, cannot but acknowledge that they are great earers. And Aldrovandus uponexperience affirms, that many infects are ho:, and Bees in particular, and his reafon is, becaufe they grieve and violently pais thofe that they Ring. In- L.Verul. Silva fects have been noed by the Ancients to feed little, but this Sil.cent.\% hath not been diligently obferved, For Grahoppers eat up the 697 , green of whole Countries, and filk-worms devour leafs fwifly, and Beeseat in greas quantity according in their bodies; which is evident to any tha: ihall obierve, what Atore they carry daily into their Hives, and what little increafe there is fometimes, after three months laborious conftant working.

It is true, chat creaturts that fleep and reft much, eate little in thole cimes, as Bats, Dormice, and Bets, Bur faich Cardan Card.de Subit is neceffary, that Creatures that fleep much, feed much, and rilotib.g. by the vertue of the meat formerly eaten in abundance, fubfit when they fleep.

All creatures almol, nore or lefs fleep, yea infeets fleep

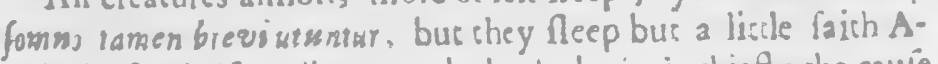
riftolle, fureiy if at all a great deal, the brain is chiefly the cauie no et Vigil. of Reep, and fuch crea:ures as have not a brain Reep nor. Bees fleep faith Ariftatle, and hee proves it becaufe they are quies, as heefaith, all night and make no noife, and they ceale not from motion, becaufe they are weak fighted and notable to move, bring a light they ftir rot, faith hee, but this is falle, for they will fye after and into a (andle, or light, like a morh, and codem. Plin. burn themielves, but fuppore they did no: ftirre with a light, nas, hit.1.1 I yert were the aryument of no force, they ftir not at a light, and $c_{3}$ ?. therefore feep, for wee know that many fowls are taken in the nighe with a lighe, at which they Aur nor, although they bie aArit de Hifto 1.4.c:10 wake, becuule they see nothing beyond or befide the lighe.

Thar they fleep from the beginning of winter to the rifing of of Arazrus fixiy duies trgether, and eat nothing at all as Pliny affi ms, is not zrue wirh us, perhaps in Northern Countries, where the culd is more intenfe, they fied litcte, and fleep for longer face. which is a principail reafon of their fo great plenty of Hony. The more temperate winters with us, occafis if there be northe laryer provifuon, a greas decay of Bees. For every 
warm and fur-fhine day, they will fye abroad, ard play, and empty themfelyes, and it ereby ottring cood Atcmacks return home and feed: whereas gloomy cold and clofe weather, nurs them in and faves Atover, and therefore a fmaller proportion will fufficiensly fupply them untsll the gathering feam Eon.

That they neep when they are abroad out of their Hives (ontheir backs) is a ridiculous fable, leaft the dew thould wer or prejudice their wings, and hinder their flighe when they awske, as Aldruvardus, and other deliver from the Ancients, fildrov. de in- And fuppole that they hould oblerve this courfe, yet could fetc.lib. $\}$ they not accomplith their purpole, for from the vapour arifing from the earth their wings would bee as much if not more wer, then if they thould stt on their feet : how loever their wings being fimy and (as it were) unctuous, the wer would not much Itay upon them.

Concerning the age of Bees, diverfe have been the opinions, Aritt de bift. fome givingthem a longer, fome a horter life, Ariftule faith, anim.l.g.e. 12 they live fix or feven years at the molt. Pliny, that they never Plin 1.9.c 3. esceed ten, no nct by fucceffion. Columella alfo laith the lame,
Cardan de varter, retum. c.28. Cari ie faich; ftrong Bees may continue twelve years. Mr. Remnaxb faith, if thev contirue in health three seass, they may Moufer.hear. Aand cwenty, Monffer luppolesh, that if they be well caied zahcs. Ld. co 3 for, and cured of their diftempers, they may live thirry jears, and ells w that at Hanworth, hee knew a ftock continued in the feeling of the houfe of the Durcheffe of $S_{\text {tmmer }}$ ei: more than shree decads of years, and fwarmed fcur tumes almoft every year and cherefore doubss with Alkeriss whether they cver d, $e$ of 2oe?

The rrath is, no: withtanding thefe mens orinions, that Bees live bue a year and a quatter at the mof, fur $r$ hi fe Bees that feem in Mlalufy, full, brown, fmoort, well nined, w.ll by the end of $\mathcal{F}_{k}$ ly followirg begin to wither, becrme is fle, look gray, and have their wirgs tortered and torn, and bee all dead before the end of Auguft. And although their life fecm thorr, yer is it more then dcubie to the Droans, but ky fucceffion tkey may contimue many fears,

Now what is to bee faid concerning the life of the Queen Bee, ic is a quere never profourdid by any (for ought 1 krow) for 


\section{A Theatre of Political Flying Infects.}

moft men corcluding thar the Bees live many years, have fup. pofed the Queen Bee to continue as long, and her life to bee of an equal exient and date with theirs. Mr. Builer that firft publined the Bees ro bee birds of a years continuance, and fomewhat more, yet ftarted not this fcruple.

It is well known, thar foms Hives contirue cen, nay iwenty. years, and more, what thall we fuppole of the Queen Bee, doth thee furvive ren, nay twenty generations; or how comes there a fucceflion of Rulers? I have propounded a queltion, wherein $I$ thall fcarce fatisfe my felf, it is not frange therefore, if I leave others unefolved.

It is manifelt that the Hony Bees are but yearly crearures, and the realon of their fhort life is their unwearied lab us:s, by daily flying abroad, incelfane working, and ponderous burdens, they watte themfelves, and wear their wings, wh'ch cou'd they renew as the Eagte her bill, they mignt for ougine I know live many years. Now the Queen Bee nor working at all, feldome 9lying abroad, and then not far, nor fo much in a year, as a Hony B:e in an hour, never tears her wingewaltes her ftrength, nor makes her felf old with labour, fo that it is more thar probable, that the may live many years.

Otherwife you muft fuppofe her mifcarriage ordinarily to be, wh en her Infanis are in their prime, and nos departed fiom her, the elder being ab!e, and ready to fucce d her, for if the hould mifcarry ar othor times before their birth, or afrer sheir Buichery, the whole fock mult needs milcarry.

\section{CHAP. XIX. \\ of Bees figbting and robbing.}

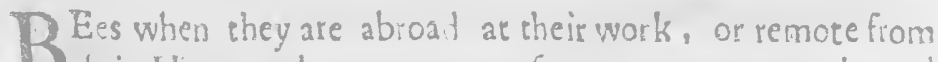
Bitheir Hives and common treafure, are very gende and Arif $d^{2}$ bift. peaceable, fo that in their private wronos, how ever you ufe them, they will noc refint, if by any means they cin ger away, fometimes at their waterings they will conseft one with another, but are quickly quiced, and parted, whereas at their Hives they are fierce and furious, they will neicher give. nor sake guarter. 


\section{$A$ Theatre of Political Flying Infects.}

Upon the union of ewo fwarms, fometimes (buc it is rare) there is at firt, elpecially if the companies bee formewhat equal, a violent charging cach of other, and the Leaders (for other exuraordinary Trumpecers have they none) with a frrill and loud noile animate and encourage their leveral companies boldiy to ftand ro it, and noe without caule, for it is their lafecy, or dea ftruation tha: all the conflict is for, and as foon as they conclude who thall govern, which for the molt part is decermined in few hours, then they will all cheerfully as one body, live and love together.

Arifterle wries of cerrain Serpents in Mefopotamia which do geac mifchief to Atrangers. bue do oo hurs at all to the inbabieanes: And Mr. Herberl cel s us, $C_{a}$ phan in Parbia, is much infefted Mr.Hesbert. with Scorpions, but a finger lorg, but of great terror in the Afing, isflaming, luch they prick with their invenomed arrow lo highly, that fome dye, mone avoid madnels a whole day, bur which is remarkable, they never hurt a Atranger; but Rees irritaced near their Hives, are ar equal enmicy wich Arangers, and domefticks ; fuch as are daily converfane with thern, if they bee bu: a liule provoked, thall finde nofavour, fo that no creature is

Avicen. fo violent and revengefnll; but althorigh the ir fp ght and malice in their rage is as much to men and beatls, as co their own kinde, yet feldome do they work an equal hurt and mifchief; and indeed the oppofrition is bitcereft beeween thole shat are neareft,fos there is a fpecial implacab!e hatred.

When two fwarms fertic togecher, and eagerly bid defiance each ro other (this falls out feldome, yer fometimes) alwayes expect a marrial and deadly skırmith.

When a company with their Leader forfake their own Hive, and en:er into another, their difference is irreconcileable, their holtility unappeafeable, but by the death of one of the Commonders; for things that are in their nature contrary, can neves be teconciled as two Commanders in a Hive.

Virçil.

And grapling fo in cluffers bead- lorg fall Hail from tbe Winers sky falls nol $10 \mathrm{fash}$, Nor B.ker Uaks josbuck ds goed ibir maft.

I had oxe two large fwarns, thas role almost immediarcly one 


\section{A Theatre of Political Flying Infects.}

one after the ocher, and before the firt were fully feted, the latt came and fe led with them; and began prefently to kill e ch other :noft defperately. As foon as I had notice of it, I caufed them to bee hived that were yet alive, half being flain in little more then a quarter of an hour; but the remainder beng hived, yet ceafed not their quarrel (although I threw Atroro drink upion them, and did what I could to appeafe them) yet they fill conte nued the batcel, that before night there was nut above a pinte left.

But alchough two companies upon their congrefs and coming rogecher with rqual forces bee thus defperacely cruel; yet whers they rob, and plunder, they hew lefs rage and ferity, but are not lefs mifchievous and hurful.

Bees are the moft dangerous enemies to Bees, they have many other, but none fo hurffull.

Some are too favourable in their cenfures, and clear them arip.de hif. from robbery. Bees, faith Ariffotle, hune after nothing, but Animill 9. labouring painfully, gather all they poffefs. And Scaliger c 64 . gives a reafon for it, becaufe they feed no: on Aleth, nor hun a-Scalig. com. in broad to plunder other, and therefore expest a reciprocal car- loc. riage from others; but by his leave, no greater robbers of Bees, than Bees, fo that though hee recurn an Ignoramus to this bill of robbery put up againft them, yet ugon better evidence I mult finde it.

The greateft danger that befalls the Bees, cumes where it hould leaft come, from the Bees themfelves. Bees are lovigg and fociable creatures, and therefore wee might thinis thould converfe one with anocher in love and peace; but inftead of fupport and protection, they do finde ruine and deitruction isom therr own kinde.

Pliny faith, when their provifion fails, they invade the r neighbours and rob them; they fight not then for their right, but to ger a booty, and under colour of warring, make a trade of Lilii Greg. robbing. And another faith, When they want meat, they Gyrald.s. r. forcibly rob their neighbours : but the matrer is quite orthwife, for u'ually the luftielt, and the beft ftored, that need nothing, willbee tirt prying inoo their poor neighbours weaknefs. They fernot upon an empty Hive, feldome upor anill furnithed Hive, but upon fome well provided ftock, where tne fatnefs of the booty is a finels to their defiris. 
Remifle oppofition provokes fiercer atcempts, they are imgudene when they meet not wich bold refitance, only refolution canmake them give back, give over, they will make many tedious and fincleffe onfers, as if the ftrongeft fort were not able long to hold out.

They firt come with a few and make an offaule, and by the oppoition conclude the iffue, but fitll renew their numbers, and al: hough they loofe many in the conflict, yet will they perfilt, and not prevailing that day, will the next morning before the true Bees bee ftirring, venture in, and if the oppolition be no: the more refolursly maineained, they will come fo numeroufly, as waters at a breach, that refiftance is to no purpore, and then thsy do tall to plundering, going and recurning untill it beedark, if they have not carried avay all before; and fo consinue till they leave not a drop of honey; to whom often the true Bees (feeing their condition otherwife defferate) will joynchemfelves, and accompany them to their Hives, and help to carry away their own goods.

As long as the oppofition latts, they are very fierce, and untill they have overcome, mercileffe, but having once made a forcibie enery, they quickly give over killing, and fall to plundering.

Somecimes many ftocks will bee up in arms together, and then te is no ealy matret to compore and quiet them.

Virgil.

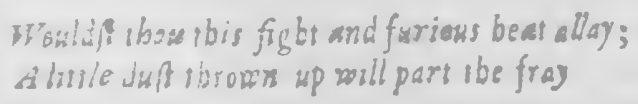

Ye: this ofen avails lietle, it is better by prevention to avoid $\mathrm{F}$, by oarrowing their doors when once mid- $\mathcal{F}_{\text {uly }}$ is paft, that but a Bee or two may enter at once ( underttand it of the poores ftocks) but if th s hath been neglected, and they bee rogether by the ears, then make a mosk of muich acd wee Araw, and stro wh water about the Hive door where the greater confliet is, Araitnirg the paffages of thofe that are robbed fometimes (if the skirmilh beeviolene) fopping them up clole, and throw water upon thofe that cagerly feek to encer, and in lefs than an hour find ng no entrance, and trouble withoit, they will resurn home. After funicr open them, and all the robbers tha? 


\section{Theatre of Political Flying Infects.}

are alive will go to their own Hives. Examine their ftate after the robbers departure, and if you finde bui a few Bees, it wil! no: bee worth your labour to trouble your felf for their preferva:izn, for a: one cime or other they will bee robbed, if nor, theg will never thrive.

But if there bee a confiderable quantity of honey ttil left, and alfo of Bees, then ftop them up again clofe, allowing them arte through a quil; but bee fure you ftop them up very well, for in the day time they will bee gnawing and mineing to make a bole our, and the robbing Bees will bee ever and anon vifiting the door, to fee if it bee open, which if they finde (if you do noi prefently ttop them in again) the lalt danger will be worle then the firt. After fun-lerallow them a palfige to go forth, to take the air and empey themfelves; take this courfefever or eight daies, and when you give them a free paffage in the day, let it no: bee untill nine of the clock, and the firft and fecoad day that you open them, Itop up their enemies, that they may not trouble them who are notlufty, as at the firt by murcing in, and in eight days their enemies will forget them,

Some pretcribe to caft flour on the Bees that you let our, that fo you may know the plundering Hives, which you may eafily otherwire, but if you do nor, rake this courfe, and obferve whither they go, when you once know the robbing Atock, with a long pen-knife, through the Hive, cut the combs towards the :up, thas fo they may find work at home to fop up what you have broken.

Although they will no: admit of Arange Bees in their Hives, yet diverfe ftocks will conipire together, and agree well to undo their neighbours: and ufually like the tox they prey furtheft from home, feldome robbing their next neighbours.

The chief cimes of robbing are Auctmn and the Spring: 11fually about the end of $A_{\text {mins }}$ st, but in dry years, about a fortnight beiore, when the honey gathering is almolt over, then do the luftuef (being molt numerous in Bees) practife it on the old Aocks, fuch cinefly that have overfwarmed, and have but a few Bees left: on fuch allo as have lolt their Leaders, who are careleffe to refitt, and will quickly go along with them and help to carry their owngoods. There is no way to lave luch, but as I preicribed tormerly. 
Another time of robbing is in the fpring, and then thole poot e'd ficcks that e'caped in Aurumn muft bee cartfully warched, foor fwarms alio thall now bee tried, until the year grows up, and the flowers bse plentivi?

Let alifuch have (as I orcered before) very narrew doors; fwarms are more difficully prevaiied agant then old ftocks; for though perhaps they have no: woughs down to the board, and lo the encrance be more ealy, yet beirg ulually more mulritudinous, they will hold ou: longer : whereas old ftccks aithuueh they have more provifion, yet have fever fouldiers, and ineserore arequickly overcome and plundered, and more eafily in the fprirgthen before.

Orce, it you perceive, that walpes in muleitudes, or robbing Bees have made a breach inco an old ltack, delay no lon ger, bue take :hem, for although b; your cilcumfpect care in topping them lip and narrowing their enrance, you may prevent their prefe : defirution, yet wilithey nctefcape in the fpring: bue if li bee a fwarm, there is fome hope, that by your care, your may prevent their prelent and luture deftruction.

\section{CHAP, XX. \\ Of Becs, Eremies asd Sirzricles.}

A LICommon-weslihs are infelted with enemies, and the A Commor-wealth of Bees as much as any other. Wee bare already fpoken of the worft, namely Bees.

In the nexiplacelet us treas of Mice, which are alfovery tur:ful sod deftufive. Somerimes they get in at the door, when ic is ietc too b.rge andopen, Comerimes they malse their wa) througb the Hive, molt commerly near the crown of it, and hey are no fooner in, but they prefently thare down the Combr, and eat the honsy; and if they be let alore, will often make their rests among the Combs. To pievens them, bee carefull of the deor; if er, eifecially in the winter, view your Hives. Ii zeuice any crumbles of wax ar the door, bee fure there is fomsinig amif lcok therefore warly, and heep traps Daired abur your lialis. 
$W_{a}$ alpes in Harveft do great mifchief, fometimes defroy whole ftalls. At firt when shey are Dew come, they content themfelves with dead Bees; but after a while they grow bolder, and venture into the Hives, and moft of all in the cool mornings when the Bees ftirno:. And after they have found the way they will never give over, bus invite their fellows, nay, they are often the robbing Bees harbingers, who make an end ufually where they biginne. And although there bee an antypathy between them and Bees, yet will they readily joyn together to plunder the poor Hives. They are natuially hardier and Atronger than Bees, one walpe will ofien violently break away from two or three Bees,yet many of them come fhorc home, being flain in the Hives by them.

In the fpring at your watering troughs, or other places where your Bees drink, and on the fouth-Gde of your pales, you may fee the mother Wafpes, drinking or gathering kill them if you can, and know shar you defroy as mary netts as wafpes, for every mother WarRe makes a nelt. Afrer when they have bred let their nelts bee fought our, and deftroyed, burn chem or fald them; or (which is fooner done) in the evening with an iron (pade (having before obferved which way they go) !eek for their nelt by purting it into the ground, and you thall know when you meer with it by the hollowneffe, then loofen the earth round and ttampit in. Serglaffes with ftrong worte, fweetned water, or fweer fruit : or racher pors covered with a paper, with a hole in the middle, and that is the bett way, for in the other the Bees will be often drowned.

The Hornet is as bardly cenfured as the walpe, bui thee is nothing fo dangerous; thee now and theneais a Bee, but the walpes deftroy whole Hives, her manner is to flye about the Hive, and when fhee feeth a Bee refing her felf upon the ftool, Cree preferzly feizech upon her, aod carries hir away in her feet, as the Hawla doth a bird. Deftroy their neits if you can withont danger, if it benolarge hole, in the evening having made a woodden plugge, fuduenly knock it in, and you are fure of them, or fee lime twiggs before their holes, and thereby you will much diminith the ir numbers.

The Titmonfe is more hurful then the Hornet, I mean the greas Titmoufe called a Colmoure, with a black head, for thee 
will eate cen or cwelve Bees at a time, and by and by be resdy fur more; the feeds ber young ones allo witb tbem. She eates not the whole Bee, but divides it in the middle, and fuils oucthe bagge of bony wicts the encral, lecting drep the skicny ou: fide.

When the comes to the hive and findss none, the knocks witb ber bill at the door, and as foon as the Bees come out

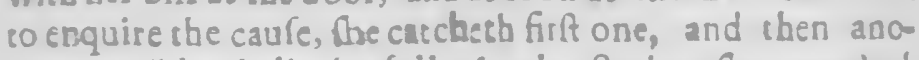
ther, uncil her belly be foll ; in the Spring the watcheth for them in the Willow and Sallow Trees, and cakes them when they are at their work. Deftroy tbeir Nefts in bree. ding time, and hoos them in Winter.

The Spider is a great derourer of Bees, if the Hives bee cmpey, or have but a few Bees, fhee will make her webs within: but for the molt part if it bee a penthoufe, thet lies between the boards where they fold one over another in the day. And in the night thee weaves her nets righ: before the Hive, wherein the Bees are quickly enfnared:

Visgil.

$$
\text { Clofe }
$$

About tbe door ber rel-like cotwebs ló,e Tbo $P_{a}$ las bated Spider Spins.

Kill the Spiders if sou can come at them, and in the morn. ings beat down tbeir nets. Many alfo fpresd them in the flowert, and smeng the brambles in the hedges, and they lye in ambuth in the cod or center of them out of light, and no focnser doth a Bee or Aye Arike them, bue they art opon then and kill them. They will grow quickly greater then large Peafe by eating of Bee?.

The Woodpecter is by many indited, I think not much guiley, vet I will not difcharge ber.

The Swaliow hath un ill.name, bue I could never ob: ferve sny great hurt done by them.

Chaucerstitin. Fos Solio mardra fe of tke Bers fmall,

b!y of For!?s.

$$
\text { Toat maker bory ef fowers frojgs of the. }
$$




\section{A Theatre of Political Flying Infects.}

The Moth with her mealineffe lomewhat offends the B:eb, but except the Hive hath very few Bees, or be altogether empty, the doth no great hurt; yet then the will lay hex blots in the Combs, which will ipoil and confame them all. Ordicarily thee breeds her young by the heat of the Bees under the skirts of the Hive, and the dawbing fnails will fometimes creep into the Hives, and much trouble tbe Bees with their coldneffe and fimineffe.

The Toad is thought to bee dangerous, though thee doth but lye under the ftool, and fometimes to deftroy them, as the Frog when they drink, but I never oblerved it.

The $P_{1}$-mires are often very hurtful, troubling the Bee?, and devouring their hony, fcald them in their netts and Aibertoderas. tarr the places where they ufe to afcend. Alberrofaith, moun- rab.mand: tain Origanum dried and beaten to powder, if it be throwed on their refts, makes thens to forfa ke thsm.

If the Antsholes be ftopt with Heliotropium; they wil Mizald arcacertainly dye.

Basrs in fome Countries do greatly endamage the $\mathrm{Bzes}$, and $\mathrm{B}$ its, thofe that breed in trees, feldorne are injurious to ihole in Hives.

Sparrows feed on Drones, but meddle not with the Beer. At firf I was furpicious that thiy deftroyed the Bees; taking notice therefore of their often flying to the Hives, and from thence to their nelts \& I caufed the young to bee taken, and found their crops full only of Droans.

Ferrets delight in hovey, and cherefore fpoil Bies, but Ariftede hift. this scaliger denies, for hee faitb, that he hath offered them Scal.com in loe. honey, but they refufed to tafte ir.

In Guines are many Bees, but all wild, breeding in trees, Pur. Pilg. 2 part and receive much hurt from a kinde of greac black Ant, $1_{0} 8 c_{0} 3$. which make holes in the earth like fitd Mice, and much damnify the Bees by cating both hony and wax.

In the Countrey of Sofala, there is a bird called by the Cufers $S_{\text {azน. It }}$ is of the bigneffe of a Linnt, and aimoft Jovordos Sanof the rame colour, with a long Bill. The chief food of toisiveropin. Cufthe fame colour, with a long Bill. The chief food of di Eithiop. orithefe Birds is wax. They leek about the woods for focks ental c 24. of Bees: And when they bave found one that hath honey, 
they come into the waies to feek for $\mathrm{Paffengers} \mathrm{to} \mathrm{thew} \mathrm{i:}$ them; which they do by crying before them, and beating their wings from bough to bough uncill they come to the Bess. The nacurals who are acquainted with tht it manners, prefently follow them, to get the honey. And the advantage that thefe birds get is to eat the wax they leave, and the dead Bees. They will come into Churches at the windows, and if they find wax candles, eat them.

Purchas Pilg. fourth part, I.7. c. I
Palladius de reruft.l. Columel. Ifidorus Hifo palen, lib. 12 Esymoloc. 8

1. Milerius re higio Boruff: $x$. Huldrichus Sibindel.
The Hirara is like the Civet.cst (though fome lay it is not) they are of many colours, viz. gray, black, and white, They eat nothing but koney. And in this they are fo terrible, that let the hole of the Bec-hive bee never fo little, they make it fo big that they may get in, and when they finde the hont $y$, they never eat it, until they have called their yong ones. And then the old one going in doth nothing but bring out i be hony, and give it to the young ones. A thing of great admiration, and an example of great charity.

In the Illand of Barbadoes, and the adjacent Inlands, are certain birds bigger than Sparrows, wich a rery greas head, called by the Englifh Logerheads and Counfellor, they live naturally on all forts of Flies, and are great de. froyers of Bees, for they have made a tocal deftruction of all thas have been carried thither.

Crabs burned are hurtful to Bees, and alfo the Imell of dung, and places fubject to Eccho's, for Eccho's and great noyfe much exafperate them.

There is no fuch creature called Clerus (as fome) bred by Bees, Moths are bred in the combs where are few or no Bees, in lufty hives they are bred under the verges or skirts of the hive, but gererated of Moths, not of Bees, as Columellda, and from him Aidrovandnes.

The Martins in Rufralive for the moft part on the tcps of Trees, and greedily devour the Bees.

$\mathrm{The} \mathrm{Cr}_{\mathrm{r}}$ codile is much delighted with, and defrous of hony, Saffion is their antidore or prefervative (which it feens he car nat endure) ro fale-guard the Beer.

The durg of Puultry is fuppofed to be very offenfive to Bees, but l have not taken nutice of asy fuch sftect, alchough 


\section{A Theatre of Political Flying InfeEts.}

though I have obferved in feveral places, that for theleer the Hens would repair to the Hives ( fuch as Atand under Penthoufes) and dung among them, howfoever (if you can) keep them away, and be fure to lee no Hens fir under the Bee-boards, for the Bees wil fomerimes come to them, which the Hens wil catch in their bills and kil; which other Bees fmelling wil reek to revenge, but with their owne defruction; I have knowne above 2 quare of Bees killed thus by $2 \mathrm{Hen}$ in a litule ipace.

Lightning, efpecially Thunder affrights, and much difturbes Mouffet theathem, faith Mr. Mouffet, and co confirme this tells us, that in the trum in'ector. moneth of Auguft, one thoufand five hundred fixty fix, be ng lib. $x_{0}$ with the Dutchefs of Somerfet, defperately difeafed, fuddenly, (on oceafion of a Atroke of Thunder) under the nex: Bed-?tear, he and others heard a murmuring and Thril noyfe, bu: a: firlt knew not that Bees were houfed in the feeling of the roome, underneath where they had inhabited thirty years.

And the day foilowing (for want of neep, as he fuppofed) flew up and down trembling, and making more than ordinary noyfe, and in a diftracted manner fruck themfelves againft ite windows, were extreamly provoked againft the Family mo:e than at orher times, fo that they are imparient of fear, as he conv cludes; as alifo of difturbance by righe, when he faith they all neep, and not at all by day; when indeed they fleep nnt all, for fome watch, and rake a conftant buzzing (in full Hives) all hours of the night, until Autumnes cold forceth them up within the Hive, and makes them to lye dofe compact together among the uppermoft sombes; yet then (if they be afleep) they are prefently awakened, not only with the leaft rouch on the Hive, but of she ground near it. Nay, if you breath before the $\mathrm{Hive}$, though at a yard diftance, they wil prefently come forth with a great noyle to examine the caufe.

Snow is very hurtful when it diffolves with the heat of the Sun, for the Bees with the heat wil be tolled out of the Hivesand they are nofooner forth, bur they are dazled, and bl nded, and cannot finde the way in again, but Hying a while up and down being weary, think to relt themelves on the Snow, which they no fooner toush but chey are killed; be fure cherefore at fuch umes to ihut them in. 


\section{A Theatre of Folitical Flying Infects.}

Sharp frolts, nipping blafts, chilling aires, drilling neee, boifterous and cold winds, in the Spring, are very prejudiciall for the Bees,coming home weary and laden, are beaten down ster in multitudes, and (unlers she Sun thine out prefently, or the winds calm) never recover the Hives. Let your Bee. garden be well defended (rake heed of an eddy wind from fome houre or building ) and let them ftand low; I have oblerved, that out of fix Hives, Atanding two foot high, and in the eddy of the wind, I have loft more Bees (being bearen down, and mifcarrying on the cold ground, then out of fixty Hives, Atanding not much 2bove a foot from the ground.

Arif. de hif. Bees are fick in dry years, and in fuch times when the flowAnimal.1.8. C.32. ers are blafted. Concerning Bees fickneffes, hear what Virgil 〔aith.

Bat if their bodies beo difeajed (as Bees By life are (wbject to exr maladies)

wbich way by fignes infallible bee krowng

The fick Pireigbt lo e their colour, and are grollan

Deform'd witb le anne s; ithey in mofal wife

Bear fortb their dead witb folemn obfeguies,

Or cloifter'd elfe witbin tbeir boules they

Sadly contain tbem felves, or lingring ftay

About the door, is clwfiers taking bold,

Famifid, and faints and feeble by tbe cold.

Colomelolog. The murrain amoog Bees is very rare : other difeafes they are fubject soo, efpecially to 2 fcowring, by gathering, or feeding on Tithymal, and the blowings of the EIm, and therefore in thole parts of It aly where there are many Elms, there are but a few Bees. I deny not but the gathering of the Elme may bee dangerous in Italy; but I am fure in our parts, which are plentifully thored with.Elms, they are no way piejudicial : Indeed they feldome gather of them.

Much ado is made by many Authors concerning Bees fickneffes, and the remedies. They tell us that they are fubj, ot efpecially to a Cacocbywia, Blapfigonia,Mar afmous and Diarrea. Whereas in all my longobfervation, I have found no proper ficknefs; accidentally indeed, when they are nece Iritared for pro- 


\section{Theatre of Tolitical Flying InfeEs:}

vifion, or nor well defended from winds and wet, they have at ill digeftion, becaule they have little to eat, and they lore their brood, becaufe they have not whesewith all to feed them; ard their nataral heat is wafted for want of meat to maintain nature; and they have fometimes a fcowring not having meat proper and good for them, they thien will lometimes gather of purging flowers, which doth nas frengehen them, buc make them more faint and weak.

And yet to all thefe various effeets proceeding from one and the fame caufe, have tho Ancients given fundry and divers names, as if the caufes had been as diverfe, $V$ arro cherefore giving directions what 2 man thould oblerve that buyes Bees; mindes him to take notice, if they bee numerous, if they bee (hining, and full; whereas if ehe combs bee not fer in 20 even pofture, if the Bees be bairy and thin bodied, they are to be refuifed, all which are but effeds of hunger.

In a word, if you defire to have your Bees thrive, and profper, keep them well from winds and wer, heat and cold, deftroy their enemies, and lee them eajoy a Mfficiensy of food goteen by their own induftry; and if there be a wane io Coms, timely fupply them, and doubi not of, by Gods blefing on your endeavoars, the increafe and profperity of yout Bees.

\section{HAP. XXI. \\ of the Hory-deth.}

7 He Hebrew word for Hony-dew is TiPר?.. jerakon, which comis from P?! jarak, and fgnifies /f wete, exfpkere, bumorem evscuare, as if it were faliva fideram (as Pliny) an excrementicious moifture, which the ftars fpit down on the fruits of the earch. By this word alfo is fignified the Kings-evil.

In Latine Rabigo is a Hony-dew, as well as ruft, a name from the effect, thewing how chat by a hureful touch, it Atops the growith of lome fruits that are obnoxious to it, making them to rult, eating out their ltare and fubltance, as a canker or rult Varro de te ruftil.p. 


\section{A Theaste of Political Flying Infects.} $\mathbf{R}_{\text {ibers com.in fretrech iron; fo thas what is a difeale of mettal is figuratively }}$ iraneferred to corn, and fuch like things $\%$ becaufe it deftroyes and confumes them, for with too much moifture the ftalks wax pale, and the corn is curned to duft ; but hee was much miltaken, not diftinguifhing between fmutty and mildewed corn, for corn affected with the mi!dew is not turned into duft, but Chrunk up, and prevented of its radical moifture, fo that though it come to maturation (for it will ripen, and is beft for leed) yet not to a full bignels and dimenfion.

Of the caufe of fmutty corn, I will fpeak briefly afreswards.

Some conceive Thrinking of corn by the Hony-dew to bee thus occafioned. In fields leis pervious to elear and ftrong winds (as in lower grounds, and narrow places berween woods and hills ? there falls often fultry and foggy milts, and thofe covering too clofe the fruits of the ground under them, as under thick mantles do calt that corn or kinde of grain wbich is fubject to shis malady, as it were into an unkindly fweat, at fuch times as the cars chereof are not yet fufficiently filled from the root, by which faint fweat is vented that fweenefs that thould feed ihe ear." Now this fweeneís once exhaufted or drawn ou: at the ftalk, or Atraw, Aticks clofe unto it being burnt, or made adut by the extraordinary heat of the Sun, as it happenech efpecially in .he Canicular dayes, which (as it may feem) ovid defaft. made the Romans facrifice a Whelp or Puppy to Mildew. 1.4. Hier.R. And this they did to prevent it, or to drive it away, of it had manode la Repub. gets. I. 2.c.7.

feized on theit corn, That this prejudice is chicfly cauled in narrow and clofe grourids wee grant, and feldome comes on hills, or large champlon grounds. But yet it brings not damage to the corn this way, bur rather thus, The corn in clofe places when the Hony-dew defcends, not being rentilared and Thaken with winds, the Hony-dew as it dries, becomes vifcuous and clammy, and fticksclofe to the Atraw, and by the heat is haidered and congealed, and thereby fops the radical moiftures from alcending, and fo the ears being nolongeried fhrink and wither. As hard bindirgor tying of a mans arm, caulech (if continued too lono) by ftopping the circular motion of the blood, a mortificarjon or gargreen. It comes not from any malignancy as fome, nor bscaule that the oily vifcuous quality, thas is in 


\section{A Thestre of Political Flying InJects.}

it ftops the pores of the hask wherein the corn lyes, and de. Fir $\mathrm{At}$ large psives it from the aire, and confequently from nourihment, this is not the caure, but what was delivered before. But hee concludes it is, and therefore commerids bearded Whear, beletrer in Mr. Harrlibs Le. caufe the beard thoors off the dew, that it doth nor io eafily infinuate it felf into the ear, and likewife caufech the car to Thake, by the leatt breath. Credat $\mathcal{F}_{\text {udeus }}$ Ape Ba. Howfoever had hee been acquaineed with the inconvenience of bearded Whear, he would rather haye flood to the hazzard of a Hony-dew.

For cure Mr. Remmant prefcribes, when you percerve by your Bees that a Hony-dew is fallen, to draw a cord over your Whear as falt as may bee, before it bee dried on by the wind or Sun. One in one furrow, and another in anotber, two or three furrows diftant as they can well reach. Qne at one end, and the other at the other end of the cord, for the leat motion will thate it off, it is fo exceeding thin when it newfalls. I dare not fay (as fome) that this can bee dorse with good profie, for materiam Superat opus, the charge will exceed the benefic. Such as fow fixty or eighty Acres of Wheat mult of neceffity imploy thany men, and perhaps many dayes together, for Hony-dews in a dry feafon fall frequently, and fometimes iwice a day, and therefore it muft be oft reiterated.

And the lors by it, is leldome great, it is rare to have ore Acre in an hundred prejudieed by it, and yet we confitt of inclolures, and much wood-land.

Pliny affirmed the Hony-dew to bee either the fweat of the Plin. Nat. bifte heaven, or the Alaver or fpicile of the itars, or the moifture of I.I I.c.I I. the aire purging it felf.

Gualitr faith, It is caufed by the inconftant change of the Guater in aire, when immoderate hearcaule raines, and cold raices expel Amcshom. I hear.

Dr. Lake faith, That too much moifture is the caufe Dr Lake in of it.

Mr. Butler judgeth the Hony-dew to bee the quinteffence of ail the fweernefs of the earth, meaning as hee explains himfelf, the quinceffence of Aowers, becaufe when the year is backward in his fruits, the Hony-dews are alwayes backward, coming only at fuch times, 25 the flowers have the molt folid and beft juice. 
Secondly, becaufe in more ho and foutherly clymates, where the fruits are more forward, the Hony-dews are more timely; in Iraby not untill $\mathcal{C}$ ay bee entred, but hee faith not ufually with us unill a monih after, whereas if the lealon bee warm and dry, ofien by the beginning of $M a y$, and fometimes 2 litele before, alwayes in May, there are with us many fwarnis.

Thirdly, becaufe the Countries that have ftore of the beft and fweeteft flowers, have ever the belt Hony. It is true, that I Jony is finer or courfer, iccording to the Howers that the Bees gather of, but this rather concludes (againft him) that the Bees gathering is not chiefly, no not very much from the Honydews ; for it cannot (alnoilt) bur be fuppored that the exhala. tion muit remain fometimes in the aire, before it bee concolted and fall, in which fpace cither afcending, or defcending by the motion of a gentle breath, it will be carried fome miles from the place where it was firft exhaled, fo that grant it extracted from the flowers, yet that which was exhaled from good and fragrant flowers, may fall in woody and heachy places, and thas which was exhaled from heathy ground according to the mo. tion of the aire, may fall on good land, his rule then cannot bee conftant. And fome years, when there are few or no flowers, yet are there many Hony-dews, 25 1652. So that the matker of chem could not bee extracted chiefly from flowers, and in ex. traordinary wet years, as himfelf inftanceth in the year, I613; the Hony-dewis fell not untill the end of Auguft, when moft flowers had done blowing, and thofe that were, had a very weak and faint juice, and therefore it is no: probable, that there Thould bee a compecent matter for their production chicfly out of flowiers.

It is agreed by all, as far as I canfearch, that the Hony-dew confilts of vapours raifed up into the third region of the aire, ex. haled from all lower bodies (noc onely fiowers) both earth and wister, which vapours being purged from the earthier and droffer matter, and throughly digeited by the heat of the Sun, and after a fort made fatter by the cold of the following night, are thickned, and fo condenfated, fall down on the earth, trees, and flowers.

Arift.de bitt.

Bees make Hony of the Hony-dew, faith CA rifotle. 


\section{$A$ Theatre of Political Flying knfects.}

Butler faith, The greateft part of the pureft Hong comes from above.

Senoca faith, It is not yet evident whecher the moifture that Sen 44 Epito. Bees gather out of Blowers be prefently hony, or whether by 2 mixture or propriety of their own, shey change it into hony. Ariftolle before the rifing of the Vergilie, denies that Bees gather any hony, but this is an apparent errour, They gather much hong, when there are Hony-dews, but yet more before any fall, if you refpect the Thortnefs of rime they gather it in. Bees gather hony more or lefs all Summer, bur lealt in Autumne, becaure the greas deves and frequent fhowers, corrup eche narive hony which is bred in the flowers; and yet Arifforle acknowiedgech where there is plenty of Ivy which flowreth in the end of Aurumn, the Bees gather much hony, but wee finde it not.

That great plenty of Hony comes from above, is acknowledged, and that the Oak among trees is principally inftumental co recain and keep the fame on his lmooth and folid leaves: yet I affirm, that there is a greaier proportion collected from flowers, than from the Ost, and all otber forts of trees, I underftand from che leaves.

This indeed is altogether gain-faid by Ariftolle: He delivers, that Bees gacher noe hony of flowers, but chiefly of the Hony-dew; and his argument is, becaule in a day or two, when the Honydews fall, lome combs will be full, and in the end of Aurumn there be flowers, but no hony, if any Hive jee eaken, driven, $r$ gelded, hee faith they would gather hony, if any were to bic found.

Wee are to know, That as greae flore of hony falls from above, fo there is a native fweetnels, or hony, in flowers, the Spring and Summer chiefly, which is not to bee found fo plentifully rowards the end of Autumn, becaufe the flowers at that eime of the year are weak and fpent, and afford litele, and that lictle, is ufually exhaled with immoderste heat, or fpoyled with frequent raines, or great dews ; fo that chere is little, or no advantage at all from them, ia refpect of hony. Some Sendara cba indeed the Bees gather then, but that will not latt long, therefore of neceffity when Bees are late takem, for want of food, they cannot live long.

Arit, de bith 1.s.c.19. 


\section{A Theatre of Political Flying Infects.}

If Bees gathered hory chiefly of the $\mathrm{Oak}$, which almolt 2lone is recentive of the hony-dew (from flowers he denied they gathered any hony) how comes it to pals that hony-dews falling lase in the year, as in the years one thoufand Gx hundred and thirtren, and one thouland fix hundred forty eight, almo ff wo months afterche ufual time, namely, in the latter end of $A \mathrm{k} g \mathrm{f} f$, when there fell divers hony. dews, bur the Bees were lietle the better for them, except only in the Heath Country, when the Heathflower was in his prime, and there thole late hory-dews made their fat Atalls, but in other places the Bees generally mifcarried.

If they did principally gather of the $\mathrm{O}_{3} \mathrm{k}$, the leaves thereof were then as retentive of $i s$, as at Midfummer, but rather hereby it appears, chat the hony-dew is received into the hollow fockets cf Flowers, and there long contained, until by the Bees it be extrated.

Hony-dews therefore falling late when molt Flowers have done blowing, not having any profer place to contain thent, are, either quickly walhed away with the raine, or exhaled witb the Sun.

Further, that Bees gather hony of Alowers is manifet, in many Inands where grow no Oakes, nor yet other Trees, nor yee are near them by fome miles (as the Inand of Foolness) yes Bees chrive very well, and yee.d ordinarily a greater increafe of hony shan in ocher places.

Pliny \{aith, the Bees gather the hony-dew from the Elme, Teile-tree, and Sallow; but our Elmes are not retencive of the hory-dew; nor yet our Sallows ofren, fometimes a litcle; more pientifully is the Hop, and would be very beneficial to the Bees, were it not for the bitterneis of the leaf corrupting the hosy; Chery-erees (efpecially the wild Cherry-tree) are recentive of the hony dew, and thercupon curle up the leaves, and fo coneain it lorger, but to their owne frejudice, for the rad cal fap or moyfure is thereby cheched, and afcerds no more, and ofttines their tops wither and dye, but the Oak of all others mct pien:ifully alfo ds it ; the great Maple alfo (vulgarly calle d the Sycamore tree) the leaves of orher Trees are more (pongie and I. Verul. forour, arid drirk it in as faft as it fails.

Si'ra Glacont.s The L.Vort am makes a doubs whe her any caule be from 496. the 


\section{A Theatre of Political Flying Infects.}

the Oaken leat it Celf, to cuncoet; or whether it be only that the leaf is clore and fmooth (and therefore drinketh not in the diw, but preferveih it )

Tha: which in Scripture is called Manna, by the wifeft of the Cxlius $\mathbf{R}$ bec?

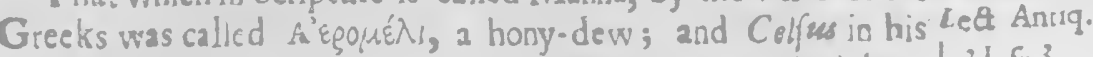
Phyick faich, by the Syriay dew is underfoo 1 shas which by a l. $21 . c .3$ Atrange or forrein name is called Mana.

The prefent Manna, and that wherewith the Children of $1 / 0$ rael were fed forty years in the Wildernefs, difer not much from the hony-dew.

Firt, That Manna of the Iiraelites, and the manna ufed by Phyfrians differ not much, Fro. Valefiss, and allo Io. Fr. Picus Fr. Valefo de Earl of Mirandula actelts the fame in certaire learned V'erfes, facra. Poiloand Lemaias agrees hereto, - Faying, the Manna row in ure by fopb. C. 37 Phyfitians is not much unlike the Manna thas the lírcibites fed of.

Tne Hony-dew and Manna doe nor fubetancially differ, the LeminusHerb. bib. explicat: Dew is not $H$,ny except it be gathered by the Bees, concocted in their bodies, and condenlated ( by their heat) in the combes; for when it is thickned of it felf, it is called dry manna ; bue if it be no: coagulated is is called liquid manna, as a congealed dew, vifcuous, and very pleafant to the tafte of which fore is that Hipp 'crat.lib. which is called Cedria, mentioned by Hippocrates, and it is che de vu'neribus, fame which the Hebrews call Manna; it is plentifully gathe. Per Bellonius, red of the greater Cedars on Mount Libanus, and Mom lib. z.obletrato Sindi.

The Characters of the prefent Manna agree to the Jews Exod. 35.84 Manna;

Firf, it fell on the ground like a hoare Froft, in the night.

Secondly, the tafte thereof was like Wafers made with hony, which agrees with the manna now in ufe.

Thirdly, it was gathered in the morning, before the Sun waxed hoe, for the heat shereof did diffolve 1t, and make it co evaporare and vanith away.

Fourthly, if it were kept, it bred Worms; I was informed from a learned Gentleman, that the Hony-dew ha.h bied Worms before nighi, of which he was an eye-witnefs in our Country.

Some gather the excrements of Bees (of a yellow colour, and 
Ievin. Lem. homy caft: ) which they finde near the Hives, and fome igtoniugh Herb.

bib esp'icas. rasily fuppole to be thickned by an acrial concretion; but this camor be, for the exerements of Bees are always liquid, and Aluid, and if shere be any reality in this repor, It inufo bee the Bec-bread, whereof much is yeliow, asd all of a heng tafte; it is gaihered in likter round parce's as bigge as fmail pirs reads, bu: they are bitsle, and broker, will no: eafty coagulate, for they are not clammy; and the Bees let many fall at the Hive doors, if the entrance be fmall : but they mafo be very fools thas will take this for Marna, wuch more they that wil be cozened witb the excremen:s.

It hash been quifticned; whather Manna was knowne to the ancient Greriass, lome deny is, becaufe the name is nor found; o:hers affirme i, as Guido Ponnyrolims, the: Manca was known to them, but not under the mame of Manas (which word the $A^{-}$ rabs browed from stie Tetrs.

Gaien fpeaking of the iame, acknowledge:h that in his time ia

Esienlib. 3. de aliment.

f3col:

Amiretus de Afix panderio bus

J. Langias 1. In Jepirifiedis 64 elevaied trom the eartho and the waters by the heat of the Sun, and then being perfectly atrenuaie 3 and concacted, are thickned, aod congealed by the cold of the right into kony, graipes, of fard, they A ck upon berbs and leaves of Trees ( Somerimes on fones, and the greund) The inhabizants tre efore fpread Hides crithe orocisd. ard besethe Trees, and that which falls (like hosy) they gachar, and pur irio earthen veffels, where in 2 mort ime it hadens, and becomes as it were like fand.

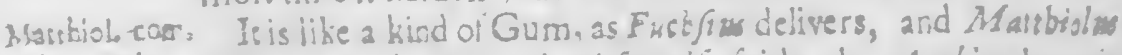
in lstr.Dio- confirms the lame; and Mefuc alio laith, she Arabian hany is fsorsd.c. "; 3 a dew falirg on Plan:s (and Sropes) whole matcer is an elcvaMelas lib. red red vanowr, which bach is digeftion and maturation in the air: gompl. $c_{0}$ \&

Galer lib. 3. divesified according to the divetriey of thirgs on which it falls de alitr. fasso.

falling on plants it participa:es of the rature of Plants, lo stbat the beft hooy 19 ufualy where ute moft iemperase Planes grow.

Noss 


\section{A Thearre of Political Flying Insects.}

Now if Galens deicription of his Airy hony be compared with this, ic accords in every thing; and $G$ alen in the lame place faith, that this Hony-dew, or Manna, is fo like to that hony that the Bees gather of, thar they have one and the fame ma:ter, namely dew,

Valerius Cordus endeavours by many (but not invincible) Valerius CorArguments, to prove that they differ; with whom Hen. Sel-dus Annotat. moulb, and Guido Panyrollus concur, and accord.

Firft, the Bees hony, raith Cordus is fuund at all cimes of the lib. ${ }^{3}$. c ro4 Spring and Summes, buc tha Hony-dew (and alfo Marna) but Guido PannySpring, and Summer, but the Hony-dew (and alio Marina) but rollus Nova refometimes and feldome.

I anfwer, that there is a native fweetrels in lome flowers at moft times of the year, and plentifully in a mild and forward Spring, but yet notwithftanding the Bees gacher much hooy, wher the houy-dews fall.

Secondly, che Bees hony is found boch nighe and day in the Flowers, but the hony-dew only in the morning.

I anfwer, It is true, that the Bees gacher hony ous of the Howers a great part of the day, but there is (bofides che native hony ) anaddition of hony from the hony. dew in the cells of the Alowers, where it is preferved longer than on the Oaken leaves, being there obvious ro every drying blalt, and exhaling raine.

And fo faich the L. Verulam, Flowers that have deep fockets, L. Veras. $s_{d}$ doe gather in che botcome a kind of hony, as Hony-fuckles (both va Gilv, cens. 7. the Woodbinds and the Trefoile ) Lillies, and the like, and in ${ }^{66}$.

them certainly the flower beareth pare wich the dew, and therefore places abounding in Manna, doe alfo yeeld plenty of Sands relat: hony; Thus Cepbalenea. Moreover, the hony dew doth not only fall in the morning early, bus in hor gloomy fealons, ofien in the after noon.

Thirdly, the Bees hony molt abounds in flowers about noon, but the hony-dew as foon as che Sun waxech hor, perilhech: I anfwer, it perifhech where it is open, and expoled to the Sun and Wind, but where it is well defended from either (as in the fmall Cockers of Alwers ) it endures much longer.

And I affirme further, that Bees gather molt hony in the fore-noon, except the bony-dew falls in the afrer-noon, and neither raine watheth it away, nor the Suns hor rayes exhale it.

Fourthly, the Bees hony while it is contained in she flowers, 


\section{A Theatre of Political Flying Inferts.}

is liquid, but the hony- dew, namely Mäthna is compacted rogether, and congealed; Anfwer, Although the hony be liquid in the combes when it is newly gathered, yet shereupon it follows not that it was fo liquid in the flower, being by a tranfcendent Chimical still exeracted forch of a more groffie fubftance, and afrer rarefied, and defecated in the limbeck of their bladder. moreover, as we ínewed before, in many parts of $A$ f sa, the manna falls more liquid, bur hardens after it is gathered.

And againe, it is true in fome parts of the World chere falls, Sands relat. $h$ or rather is gathered this concrete, or coagulated hony (the 4 right manna ) Manna in Calabria is gathered from the leaves of the Mulberry-trees that grow higher in the mountaines, it falls like a dew in the night time, like a dew, and therefore liquid; it is gathered from the leaf of the Mulberryatrees, but not of fuch as grow in the Vallies, and it falleth upon the leaves by night.

I. Verulo Sils It hiould feeme that before thele dews come upos Trees in va Gil.cent.8. 983 the Vallies shey diffipate, and cannor hold out; it thould leeme alfo the Mulberry leaf it felf hath fome coagulating vertue, which confpiffareth the dew, for it is not found upon other trees.

And it is more than probable that that Manna that is gathered rogoulated, hath its condenfacionfrom the vertue of the tree, or plant from whence it is taken.

Pedro, Teirei- In Perfia they call Manna Xirqueft, Xir in Perfan is Milk, and ra de los.

Qufft is the name of the Tree which produceth it, or rather Rryes de Per- whereofit is gathersed the beft comes from Hiez, from whence fial. soc $z$ it is carried in greac quantity so Ormwz, and from thence throughour all the Eaft; it is.white, foft, fweer, and-in Graines like Incenfe or Mátick.

Jdem lib. Io ร. 23

They have another fort called Toraniabin, gachered on certaine plants like wild thiltles; there is a Drug or kind of Manna brought from Ultrad, not farre from the River Sird in the Eaft Indies; the Naturals call it Gerkar, of Kar folt, and Geu fat, for of the dew which falls and congeales in the fowen fields (mark, it falls liquid ) it is gathered and called by us Salgeu, and more corrupely Salgema.

I muft a lietle digrefs to reforme a Geographical errour, the River Sind which was mentioned before, is the principal of five of which sheRiver is compounded, firft Belbat, which arifeth 


\section{A Theatre of Political Filying In fects.}

near Rabul towards the coaft of Perfia. The fecond is called Cbanab, which comes from the Province 2uexmir fifteen dayes journey diftant from Labor. A third is called Ruoy fpringing near Labore A fourth, $\mathrm{Via}$; And a fifch Sind, which Mr.Herberes giveth name to the Land and Kingdome, commonly cal- Travels into led by the Portugals Sinde. And therefore Mr. Herbers was Africa and deceived, who fuppofed the River $\boldsymbol{I n d u s}$ to bee called Sind. To Afiagl. 1.

return again
In the vallies of Cbile in their feafon fall great dews (which Ant.deferrera
decad.7. . 1. 1.c.7 collect and harden) like bread tempered with Sugar or Marchpane (Mark, they fall liquid dews) which is as wholefome as that which they call Manna : By all which inftancee, it appears that Manna is firft a liquid dew, and after infpiffated by a vertue of the tree, or plarte on which it falls, and falling un other plants ortrees, it never cordenfate.

From the Ciry of Baljora fcituate in the end-of the Red-fea P.Teixeira on the banks of the Rivers Tigris and Empbrates, is brought a relation de los kerinde of Manna in boules like thick hony, fo chas fome Manna, Reyes de Pero is.never coagulared.

Fifthly, Hony-dew is contained in flowers, but the Honydew falls on leaves of trees. Anfwer: only on leaves of trees ? Norhinglefs, on flowers alfo, and a great part, as I thewed before of the hony in flowers, is not natural but adventicious:

Sixchly, The Bees hony doth not ondly laft longer, but conferves other things, and that many years; but the Hony-dew, or Manna will not keep uncorrupted one year, nor yet preferve orher things from purrefaction; and in the Northern Regions there is plenty of hony, but rarely any Hony-dews.

So Magirus Hony-dews are very rare in our Countries, in Jo.Magirus regard of our cloudy aire, but frequent in the Eaftern Coun-phifiolog.1.40 rries. Anfwer, That the lafting of hony longer than Mannac,6. may bee from a further concoition which it hath in the Bees bodies, as alfo from the continued great heac of the Bees after it is repofized in the combs, whereby it comes to further maturasion and perfection*. And whereas hee lairh, Hony-dews are *Vide Cap $j_{2}^{2}$ rare in the Northern Regions, wee ofen by wofull experience of the Brafiliars finde the contrary, receiving by the frequency of them, grear ${ }_{Z}^{\text {Beelloh. }}$ prejudice in our hops and corn.

Seventhly, If the Hony-dew bee the matcer of hony, how 
comes it to pals that it falls onely on flowers, and not on the plants and leaves of trees? Anfwer, It falls not only on flowers, buc on leaves of trees and plants alfo, though fome plants and leaver, are not fo tenacious, and retentive of it, as the great Maple, and the Oaken leaf, bur being more porous and jpungy, fuck it up, and confume it.

Laftly, When the Hony-dew falls, the Bees gather it, and Hock to it, but onely for their prefent repalt and food. Anfwer, There is no rultick converfant among Bees, bur knows the contrary, and by experience can fay, that they then gather more hony in two or three dayes, than in swo or three weeks after they ceale.

Ribera, as you may remember, atcribures fmutrinefs of Wheat Helmontrus : to the Hony-dew; and Helmont feems to be of the fame opinion, mulus pefl s. calling it Triticum ror atum five melitum, and fo do fome others alfo. Now in a word to undeceive them. The caufe of fmutty Wheat, is not at all from the Hony-dew, nor yee from any of thofe caufes, that the author of the firt letter in Mr. Harilibs Legacy delivers. Nor yet is it a deficiency onely in the regetacive faculty, for it grows and produceth a blade, and an ear, but then it wants power to quicken and give life, as it were, by blowing to that corn that is put out in the ear; fo that not being enlivened, it proves abortive, and turns into a ftinking black powder (Corruptio optimi pefsima) Imelling like a red Herring, or Carrion.

Now this falls out for want of a nitrous, and thereby a nueritive quality in the grain, for it is moft certain, that falt is the feat of life, and vegetation, and fo the fubject of nutrition.

This by the way, take notice of, that they are molt under ears that are fubjeat to that malady, not therefore fubject to it, becaufe shey are lower than orhers, but therefore lower, becaufe of 2 deficiency and weaknefs in the regetative faculyy. And ufually if one ftalk hath the ear fmutty, all ehat arife from the fame roo: are infected, yet it falls out (though rarely) that fometimes one fide of the ear is good corn, and the other bags, for one fide blows, and the other doth not, and whatloever blows not, will be Imutty.

Many years together I fuffered much damage by it, but knew not how to remedy my felf, but after the projection of divers 


\section{$\triangle$ Theatre of Political Flying anfects.}

divers experiments, at laft fuccefsfully, I fell upon this courfe, I cauled a Hog -head of fale water to be fetched, and put into the water near a bufhel of Bay-falt not at once, nor yet into the Hogf-head, but pouring half of it at a time into a Tub, I after pur in half the fale, wherein when it was meleed, I imbibed my Seed-wheat thus: Filling a clofe well-wroughe Ozierbasket (that would admit the water, and hold near a bu(hel) with Whest, and then pur it into the Tub, holding it by the ears, and when it was all well moiftened, rook it out, leteing the water drain as it ftood on the Tubs fide, into the Tub again. And when it began to leave dropping, poured it on a floor, and Atrewed upon it as it was turned over, near a thovel full of naked lime, not that lime addes any thing to the vegetation (perhaps it accelerates the growth) nor yet lecures it from vermine (as fome conceive) but onely dryes it (being done over-night) that it is more nimble and better to fow the nezt day. Lime without fteeping your corn, doth not prevent fmutrinefs, but corn thus imbibed, and then fown wishour lime, will not rmur.

Thus adventitious Sals fupplies the defect of that nitrous quality which fome grain are defective of, and are hereby quickned, refrefhed, and as it were impowred to perfeft regetation to maturation.

Such as are remote from the fea, muft make a brine which will bee every way equivalent, onely more chargeable, I have many years made trial of this conre, and without any greas curiofity, for my feed have had conflantly bright wheat, and fo alfo my neighbours, to whom I readily divu'ged what I found good for the publike; but in my publick Difcourfe, forget too mach my private Defign.

\section{CHA P. XXU。 \\ of Honyo}

Ardan affirms, Tha: neither Hony nor Waxe is made by Cardin lib. g? dany creature but a Bee, which is a truth, if . wree take ir de fubril. 
conjunctivcly, otherwile nor. There is ro other creature that makes both hony and waxe.

And that which Scaliger laith, Fliny obferves out of AriSealiger de forle (which I remember not) that Walpes make wax, is falle fubcil. exercito whofoever a firms ir. Combs they make, as fome orhar Infects, 191. but they are not wax, bue droffie collections of old pales, and other old wood, cempered with a gummy liquor lowing from the Osk, or (felled) Elmes whereby they become rough and capable to coneain their yourg. Try to meis them, and you hiall quickly refolve your felf.

And whereas Scaliger la:th, There is in the Molucia Hards tooy made by Flies leis chan Aars (the truch is queftionabie, for $i:$ is oncly repored by $\boldsymbol{P}$ igafess $)$ I fuppore hee called them Flies, oreily for their fmainels. The earth-Bee, with us a kinde of wilde Bee, is fmaller, and yer gathers Bee-bread abusdankly, and hony allo for ought I know.

And molt of the American Bees are not bigger than Flies, bur yer are Bees, not Flies.

And for his inltances of the folidity of fome hony (admitting of the Hiftories) they do not at all enervate this pofition trac Bees onely make honey.

Among the Trogtodites in a Country called Balgada, there is hony found whiter than fnow, and as hard as a ftone; And in the Counery about Calicws the hony is fo hard that they carry it in baskets, what then,was it not made by Bees? I have fee. as white, and as hard made by my own Bees. Indeed befides the domertick Bee, the humble Bee raskes hony, but lietle in quantiry, and noshing fo pleafant in tafte for quality.

In Cbina there is not onely plenty of Bees wax, but there is Math, Riciide anotherfore which is not onely whiter, bur alio better, for it is Curiftans ex. lefs slumroue, and beirg lighted, burns brighter : te is made of Fedis apod Si. ras libis. ceitwin uvims which ahey breed up in erees for this purpole. They maie 2 third fors of a fruit of a certain eree which is not le:s whice thas the former, but bumes notsing fo brighrly.

Thus havewee found hooy and wax 000 , made by cther creasures befides the Hong-Bees, but boih by no one ecea= curc.

Lxhaxign faith, Hony and Wax may be gathered withour the Bees 


\section{Ditheatre of Polivical Flying Infects.}

Bees labour, there is in the flowers, faith he, and leaves of Andreas Liplants, toth tony and wax, which by fublimation may be cafily banius, lib. 2 . fegreosated, but as a frutlels and needlefs fpeculation, I wil not I. $_{0} 45$ ingilt upon it.

Gorrtbeus faith, hony is a fweet juyce, hot and dry, it feemes Mat. Mirtirii to have its oijgial from the Hebiew ajy which is delighe, lex Philolog.

and khence the Germane Honig, which wee con:racting call bony.

By hony Metaphorically is underftood every plealanty dainty, Diefionar Eand Tavoury mea?.

Hony is the Symbol of Death, as Gallis of Life, wherefore the

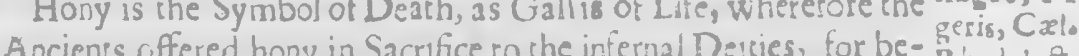
Ancients offered hony in Sacrifice to the infernal Deties, for be-Rhod. lectancaufe of pleafure, death creeps on us. ria.l.6.c 2

Hony fignifiech Marriage, faith one, and is taken Figuracive- Barradas itine. ly for carnal pleafure, and fignifies a worldly life, not abhor- rarium tilio. ring delight, formarriage is honourable; nor is a Chriftian to rum If:atles be blamed thar lawfully ufech it. Bur as in the old Law, al- Egyp:ol:b. 6 . be blamed that lawitily uiethit. But as in the old Law, al- $c_{0} 5$ though hony might be received for gifes, and fult fruits, yer i: was forbidden in Sacrifice : to in the Church (only the Koman Church) the hony of Marriage is honou:able in Lay-men, ye: are married perfons prohibited the Altar, for it is no: lawful for 2 Prieft to be married.

There are many forts or kinds of hony; Acrial, Manna, Reedhony, Sugar, and that which is gathered by Bees; the bett hony is that which is lo pure that it glifters yellow (Ariftotle commends the white) having a good fmell, not too hard, nor too thin, fweet to the talte, and hanging together, once being boy= led yeelds litele cum.

Another faith, that is the beft hony which is in a mean be- Scolia Guil. sween thick and thin, fweet in tafte, and yer thaip, pricking the Plantri in Ferw congue ; for colour eicher pale, or pellucid, and hethod. congue ; for colour either pale, or pellucid, and thining like medendi. lib. I Gold, odoriferous and new, and which taken up, hanos lo together that it wil nor be eafily feparated ; in a word, the beft is at the bottome.

A meafure that containes fifteen ounces of hony, wil hold but ferne! me, ten cunces of wine, and nine of oyle. thod medend:,

Diopbanes prefcribes to know adulterate hony thus; if it will $1.4 . c .6$ not burne purely, bur rasher thus; mele a litcle in a porringer, Wectser. de and feqses, lib, 9 
and if it be adulterated with flower, or any thing elfe, you thalls perceive it by the fcum; if it be pure, it will be as clear as rock uncer.

Porcacthi deforit del ifole di Sicilia,

New hony is better than old, the Sicilian was with the Ancienis in higheft eftimacion, fo that by a Proverb, the Hybleas was notorious, Bankin commends the Atrick before alt other.

2. Verul. Gl. Some imagine that the chief labour, or rather skill of the Bee Sil. cent, 7. Arif, de. hift. lub. S. c. 22

is about the Wax, and that the Bee (according to Ariftotle) gatherech hony only from the hony dew; but this wee made clear before, that he maketh, that is, extractech more from the flowers, than fhe gathereth from the irees,

Cardane fondly fuppofeth, that they neither make, nor $\mathrm{ga}^{\mathrm{a}-}$ ther properly, but convert what they gather into hony, by vertue of a little bagge or bladder fweer as hoay; and like faith he, is made of like.

Various are the opinions of the Ancients concerning thofe that frit found out hony, with the nature of Bees; fome fay by Eubemernes in the Ifland Cea; others, by Entbronius, in the dayes of Ericbronius on Mount Hymeste, a Country of Atsica, Nicander laith in Creet, in the time of Saturse.

Augnat Serors Arifrodemns the Philofopher Audied many years to find out ad frat an ere. the nature of Bees, and could not; Ariffomacbus faith Cicero did mo. nothing elfe for fixty two years; and Pliny faith of him, that he: firtt raught and found out the encreafirg of Bees, and was fo earneltiy affected to them, that he fudied day and night how. bee mighe bett order, and intreas them ascording to their kind.

Others afcribe this inyention to one Thaffias, who deferved Diad. Siculus great commendarion for his skill among Bces, Diodorus faith, lib.6

Macrob. Sa* zurnal. I : Zuttin. 1 ib. 13 the Curetes, a people of Creta fieft found out hony, Mecrobius alcribes, Dioderus, and Plmy, and Columella, to Arifteus in $T$ beffalie, to whom 7 ustine agrees, although in his forty fourth Book he alcribes it to Gargoris, but only I conceive for Spaine; fabur Polydrr, Vir-lous Ber./u cites fim by he name of Melicola, Polidore to the gilde invent. $F_{\text {ers: }}$ I hold it ancienter, for $\mathcal{F}_{\text {acab }}$ lent a prefent of hony to the seruni.lib.3.c.3 Governour of Eg.pt.

Godignus de In no part of the world is more hony than in El tbiopias the Abiffinor caule whereof is the plenty of Flowers which grow there (lec. 
Such take aotice of it that deny Bees gather hony of Flowers, and rebus, tib. $x_{\text {. }}$ the many Rivers, Lakes, and Waters.

Ilerjagagben a Town of Hee in Africe abounds grealy with I. Leo. lib 2 hony, which ferveth the inhabitants both for food ( confitting of swo hundred Families, having neither Gardens nor Fruit-1rees, but only Barley and $O y l$, the inhabitants being (loathful) and for Merchandife to fell in the neighbour Countries, they cata 2way their wex.

The Mouncaines in Africa are mott plentiful of hong, whole I. Leo. Ist. 2. tops are always covered with Snow, as Nifif'a, Senfana, Tago- \& lib.3. daft; Thogia, Beni-fenefcare, tur white hony is there a rarity; yet in the Kingdome of CMorocbo they have very much Calii A ugu?to hony, fome for whitenefs like so Milk, other dear and yellow Curionis, Malike gold.

Po:and abounds with hony, which they finde in hollow trees, and $C$ a ves of the earth, befides the Husband-mens Hives.

In $\lambda$ f cono there are no Bees, and if they be broughe thither Col. Rhad. they dye.

Mycuro is one of ihe Cyclad Iflands.

In lreland are many Bees, as well in Hives ar home, as in hol- I. de la Hiye. low Trees abroad, and Caves of the eartb, contrary to Solines threfor ice and Ifidore, and it is as good as in other Couneries, and more chartes ftore would be there, bur chat there grow fome Trees that are venemous, but what thole Trees be he names not,

Aldrovand fai:h, chere be no Bees in New Spaine, and Ifadore relates the fame of Scoiland, and faith, that ftones and dult brought thence and laid in the Hives, makes the Bees forfake them, butfalfe, as Polidare acknowledgech.

Malta is houter by much, than any otber Country which is angl. feated in the lame parallel withowt Rivers, but hath fundry Sand, relat, fountaines, and hony in 2 bundance.

And the plenty and goodnels of the flowers in Maita is the caufe that it affords excellent horiy, therefore faith a learned Phifi:ian, that Hony is Flos florsm, the flower or quincelfence of Mari'ius Ficiflowers, nourithing not a lietle with his fweecnets, and prefer- nus, lib. 2. de ving things from putrefaction.

Polyd. Vitg:

lib. 13. hith. lib. 4 Porcarchide= frrit del lioldi Malsa. det.c 28

Sicilia likewile though hot, yes is fored with Rivers and Fountaines; the Winter mott temperate, no day fo tempeltuous, as affurdeth not fome Sur-mine, and about Enna the 
flowers are fo numcrous, and fragrant that the Dogscanion bunt.

In Podolie, aed indeed all Sarmatia (underftand Sarmatia in Hier. Girava Europe, for there is Sarmatia in A/ra ) now it contains Poloniag de Cofmograph.

Ditionar,EtyRufia, Praffa, Lituania, Livonia, Podolia, and Mofcbovia: whercto is added Alba, Ru/sia, and Vandalia.

In a word the people were anciently known by the name of molorri lingue fungeri.

Clao Mag. hildedlle cole Septen.l. 22, Scytbians. Here is more hony then in all the world befides, for they fill fometimes great dry pits with combs, that the Bears coming to eat the hony, accidentally falling into them, have been Cuffocared with the abundance.

Nacure denies them the vine, but the God of nature hath Gio. Bocerole more than fufficiently recompenced that defect with an increrelationi uni- dible quantity of hony, which they ufe (befides to leveral other verf. fali z part purpofes) to make mead with.

l.r.

Mendola,

There is great abundance in China, for they wonderfully deTreatife of the light in keeping of Bees, there is alfo very much wax,you may Kingdom of lade Ships, nay Fleets therewith.

China.

G.Fletcher

Rufle Com: monwealtb.

Hony is more plentiful in $R_{H} / s i a$ than in any part of the world, thereof they fpend great quanticy in their ordinary drink (which is Meade of all forts)and many other ufes, and yee good quantity is carried out of the Country, which may better Iettere d'Ab. appear if wee take notice that there hath been Mipped fifty
Campenfe in thoufand Pood yearly of wax, every Pood containing forty te taole core di Mol.\&́ P. Jopio delle co. pourd, which amounts to a choufand Tun, and yet the great men ufe but little Tallow, but much wax for their lights.

Muffat perftringech fouius for applauding the Rulsian hony, fe del. Mor. apad $R_{2}$ hamufro for faith hee, There is not a Bee in the whole Country, and hee 2. Voluma. juftifies himfelf from the relation of Sobafion Baro, hov truly from the premifes you may eafily determine.

About the River Occa, diftant about thirty Leagues from $P$ urchas pilg: Mefro, is the grearett ftore in all the land of Rufsia.

3.part.1,2.c.s. Inccurage. ment of ferling a Plantar, at

There is a report that a greater quantity than that mentioned before is brought yearly to India, from the Coat of Malindia near adjoyning to CMadagafcar, namely fifteen hunmadagal. J. Leo dred Tuns. 1.8.

There is litcle hony throughout all Egypt, and that little is not very good, for it is alwayes moift and thin like water, the realon where of is faid to bee, becaufe the flowers are ovee 


\section{A Theatre of Political Flying Inferts.}

moilt by the overflowing of Nilus, bus in America, where the Ale Apbcdis lands are not overflown, but exceeding dry, yet the hony is a!- Prob.74 wayes liquid, fo that it comes from fome other caufe.

Corfica yeelds many venemous trees, from which if the Elates of the Bees fuek any thing, they make the hony very bitter; It feems world trantiat. the fe trees were bu: in fome places, for Atbereus reports, that by Ed. Grimtt. the Corficans were long lived with the daily ufe of hony, which is very plentiful with them; Dome parts were infainous for their Servius com. bad hony, occafioned through their plenty of Yew trees, which in 4.1. Jeorg. Servius confirms, laying, The Corfican hony is bitter, and Martial mentions it.

Some vainly conceit, all hony at firft to bee (harp and bitter, Martial 9. Epi. bur in procefs of rime being iweetnef?.

In the City of $\pi$ rapezunt in Pontrs, the hony gatbered of the Yew trees fmells filthily, and makes them that are well in theit wits, mad, and but cures thofe that are diftracted.

in Greg. Naz, $42.0526 .43^{\circ}$

In fome parts of Spain the hony is poyfon : Alfo at Heraslea in Ponius fome years, they have an herb called Aegoletbron, hureful to Goats, the flowers whereof, efpecially in a wer Spring thave a poy[onous quality. Signs of it, it never thickens, the co= lour is more red than orther hony, a trong kinde of fmell, prefently it caufech fneezing, they which eat of it throw themfelves on the ground feeking to cool thernfelves, for they are all on a fweat. And if dogs eat their excrements thar are affected. with it, they have the difeale.

Likewile in $P_{\text {ont }}$ among the Samni, there is a hony whica caufeth madnels, which is luppoled to bee gathered from the Plin. Nat. hif. $R$ bododendron, whereof the Woodsare full. In fome parts allo 1.21.c.1 3 of Perjas, and in Getulia, a Province of Mauritania.

Galen laith, his father had hony fo bitter with age, as if it Gallen, b 1.de had been gathered in Portus. And therefore Servius on thole Antidotic. 2 words of Virgil, Dulicis meltapremes, faith, It is not a fuperfuous Epithire, becaufe there is bitter hony. . So is there Sharp hony allo which comes by age.

Idem 1.3. de

The hony is bitter near $P$ bafis, and about Hereclea a City of compolmedic. Pontus, from the plenty of Monks-hood, or Wolfes-bane, lecund Gen. faith $D_{i v}$ sordes.

Pet.Bellonius faich Thefe Coutries of Pontus abound with Diofcoridal 6 
an herbcalled Blackecamileon, the root whereof hach an excreicency called Ixia, which is a deadiy poyion, and kuils prefently thole chat drink 1t. Now, laith he, if the Eecs gacher che libAtance of the hony from the Chameleon-flower, there is no doubr bus the hory is very dargerous, but lasih hee, wee are no: igoo:ant, thas the Bees gaiber not the marter of thest hony from the flowers, but oneiy of the leaves when they are covered with the Hony-dew. But this great cbierver, for want of obfervation failed, trufting too much to Arifzolle, and osters, that the Bees did not make, but onely gaiber hony.

The Saxri of whom wee fpake bifre, paid a tribure of Waxe to the Romsins, bus the hory, as dangerous, was sot vend ble.

straboli1: Strabo writes, that the people called Heptacometes beyond Colcbos, llew three cohoris of Pompies fouldiers when they palfed through the mounatain Couniry, for they mingled a rinde of porfonous hony wich their drink, and eafily maflacred them when they were befides themlelves.

Dod.Siculus, Diocorks reports, That the Grecians returning from Babylon \{.r. 4 in the Counery of Colctess, found abundance of Bees, and did Jiberally feed of the hony, bus as lonn as they had eaien is, they became mad, and prefently chiew shemiclves on the ground, and lay like dead men; but the day after, the fame tour they were eaken, they recovered their wits again.

D:o? cos 1.8.

c.75.

In Sardinia is no venemous creaidie, yec the hony is poyfon. Diocorisies laita, It is very bicter, and that they gather it of wormwood, and thas it is exceilent to cure blemithes and Galenlib. 7 de pors of the tace. Galis mentions it, laying, If any hony bee fimp. facul. bitzer as the Scrdixion, it is of 2 mixt faculicy, as if fome of Nied.

our hory were ecmpered with wormword. Virgil fai.h, It is Diod.Sicul.1 6. gastiered of the Yew irce, Sic tua Cyrreas fugiant, examing laxus. Diociorus from the Boxtrce.

Plino Nartift. In Cardia there is a mountain cailed Carris, nine miles l.ar.c 54. in compals, in which face, no Flies are erer leen, and theyncver tcuch hory tha: is mace there, and brought from shence.

In Th acia she hony is not only folid, but landy, luch as is gathered in the Heath-ciuntry of Ham, Soire, reiy ccurfe, and red, fuil of liete closs us knots, like land, bu: much greater : 
Pliny dillikes it on good grounds, as the worlt hony.

All hony hardened, keeps the fame folidity, diverfe from water and other liquids, for all other liquid things once compa \&ed, dry, and are atcenuated, buc hony doth not.

That hony works as wine in the comb untill the twentiech day (afferted by fome) is a fable, and that the cover that ftops it up is the feces from the working, which they that maintain tbe former deliver, is as ridiculous; make trial, and you hall fude it. wax as the comber.

Some combes in pienciful years, are hut up the frit day.

Hony in the comb is all pure, but after is is exprefled, fome feculent and dreggy matter, nartly from the combes, partly from. the Bse-bread and fpar, Comewhat corrupes the purity, all which it purgeth up tothe top, contrary to all other liquids. where the fediment is at the botrome.

The ufe of hony was prohibiced in the old Law, becaufe it is a. fymbole of plealure and delights, in regard of the fweerneis Fr. Valefius de thereof. Now pleafures are difpleafing to God, no lovers of racro Pbilofo. hem can offer oracefult facrifice unco him. Therefore the c 16. Philofopher faid, Becaule of pleafure, wee doe wicked 1.2.5.3 things.

Anorher faith, By prohibiring hony in th: Law, wee are to Cxlius Rhod. underftand Philofophical oftencacion, and pleafant allure-lect. Antig. ments of humane eloquence, very fwet in found, but not in $1.28 .6 .2 \%$ Subltance.

Ansther, Hony was noe offered in lacrifice, nor yet wax. wherein hony is depoficed, buc oyl for the Lamps in Gods' Hieron. Epift Temple, which was expreffed from the bitternels of the a ad Gaudent. Olive, for vices are fweet, and therefore the Harlots lifs drop as $2 n$ t. I \& E Epift.ig. Hony-comb.

ad Euftochilum.

Aquinas faith, Hony was not offered in facrifice, becaule it Tho. Aquin. was o dinarily offered in facrifice to Idols, and alfo to prohibir, 12.9 .102 .3 .34 and avoid all carnal fweenels and pleafure from thofe, who in m. rended to offer facrifices to God.

The heachens ufed hony in their facrifices, efpecially the Stuckius Sac.

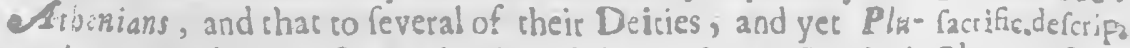
tarcb propounds a queftion why they did not ufe ir. But is is Plut quefts. cercain they offered no wine to their gods, but water fweened Symp: with bony. Hier: Romano 
Goodwin

The Ronans had divers names for their Religious places, Aneq.l,1.e,ar one was called Srrobiculus, which was a furrow, or pie, con\& Alex. $a b$ Alex.genial dier. I. 5. . . 26 eaining an Alear in it, in:o which they powred the blood of the

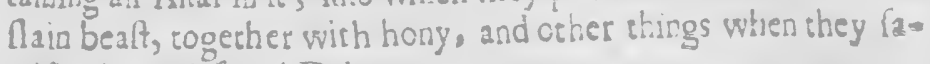
crificed to an iofernal Deity.

Hier. Romano Tue Romans facrificed to Plwothree times in the yea:, the 1..c.8

Guil.Moles unvailed

Idem.l.2.e 9 bealts for facifice were b!act, oid, and barren, ard chey made ready in this facrifice a drink of wine and milk, mixed with hony and blood.

One gives this as a namiral reafon, becaure be ng burne, ic bad no good fm:ll,

In the Featt of Baccbas, all the Priefts being crowned with garlandscf Ivy, offered facrifices made of fine flower, and hony fried wi:hoyl, and fomecimes with hony, becaufe $B_{a t}-$ class, as they fuppofed filt found them out. Hoiace faith, Forat.s cam. They lacrificed hony taken out of the Ccmbs to him.

Bacibus by fome was called Bry,eus, from an o!d word, Esu's to flow, becaule he firtt taughe the ule of hony: And Orid.1.3. Faft. Ovid faith, That hee was not onely the inventor of hony, but that hony was offered in facrifice to him.

Plurarch d:

Nidar. \& Oúr.

The Egyptians witien they celebrated the feaft of Merchry, did eat hony and figs. Hier:Rnmano Among many orher things which the Romans offered in fa-
l,z.c. If crifice to Ceres, they ufed to prefent hory and wine. And becriluce to Ceres, they ufed to prefent hory and wine. And bewith corches, or candles, which Thee lighted in the Vulcarean mount Etra, therefore a day of burning lamps and candles, Goodwin An. was dedicated to her by the heathen, and from hence came the I.3.c.13. fealt of Candlemals among the Chriftians.

Alex.abAlex. In the facrifices to Bona dea, or the earth, they ufed wine, genial dier.l.6. but called it nor by the name of Wire, but Milk or Hony, and c.8. the velfel wherein it was put, the Hony-veffel.

The ancient Greeks quieted or appealed sheir dead with Eurip,

Cbaucer in the hony, Ipbigersia in Euripedes vowing facrifices to her brother, promifech to fprinkle the blood of a Mountain-calf, the liquor of Barclius, and the labours of yellow Bees.

Choucer rclating the burning of Arfire, rells what they ufed Knighirale. to caft ingo the Funeral flames. 
Wit b vefols in ber band of gold for If fire, AL full of Hony, Milk, Blood, and Wine.

They gave the decealed a Wafer tempered with hony to ap- Adr. Turneb. peafe Cerberus witnall.

In Pelopone/us they began their facrifices to the goddefs Hier. Romano Melifo which was adored among them, becaufe Thee taught lib.z.cap.l. them the ufe of hony.

This Goropius denies, for hee faich, Noab firft afrer the de- Gornp. Becan, luge facrificed to God, and God fmelled a fweet lavouro Hicrogliph This was the firlt banquet after the flood, wherewich Noab l.13. feafted Fupirer, for which, becaule it was fweer, hee was called Melefus, namely for offering hony to $\mathrm{Z}$ upiter, and becaure this Hony-fervice or facrifice cane from him willingiy, hee was faid to have a daughter at home called Meliffa, namely the hony goodnefs of his minde, whereby hee made a feaft to God.

And then becaule with ihis lweernefs, or Meliffa, hee prefently obtained that favour from God, by which hee was abundantly fuppiied with all ne ceffaries; for this, hee was faid to have another daugheer, which was called Awalt bea. So that having Melifa ${ }^{3}$ goud will, and Amalibea a large plenty of all things; and by thefe his two daughters daily to fealt Fupiter, polterity fained that fupits being an Infanc was nourithed by the daughters of Melifys.

In ancient rimes, Junkets prepared with hony, were proper Pinedz derebus to marriage folemiities, of which cates, or honied cakes, the Solom.l. 8.0 .12 Bridegroome fist tafted, and then the Bride, and afser the Guefts.

Cartiws fpeaks of it in Alexanders marriage with Roxane. And Pineda faith the fame of Solomons marriage with Pbaraobs Cant. s.t. daugh er to bee obfcurely implised, I bave earen my bong-eombe mitb my bony, I have drunk my wine with my wilke; Eat $O$ friends, drinke, yea, drinke abundantly, $O$ beloved. Which is aa invitation of the Spoufe to the tafting of it: Where the Septuagint Reads, I have ecter my bread wisb my beny. Moreover is fignifies any extraordina y fweetnefs, as alfo milk, or any more pleafane daincy. And truly hony and wine feecra to bee proper to Nuptial fealts, which is more clear, Ezck.16.13. For wheri- 
as all the relt that went be ore concerned marriage; this was a wedding Cere nont to eac bread made of fine Flowre, Hony, and Oyl by the cum nunion where uf the Bride was taken into the Partnerhip of the King bed and Kingdome.

Jo.Leol.3. In $\mathrm{Hez}$ after the E'pu ufals and Marriage ceremonies performed, diverfe Gueft are invied to a Banquet, where for great dainties is firt biought a kinde of breal fried and tempered with hony.

A mong many other Nuptial ceremonies which the Borufsians J.Miletius ufe, after they have walhed the $\mathrm{Br}$. des feet, and with that water Religio, fprintled the Marriage-bed, and all the utenfils of the houfe,
Burugiorum. Butulforum. and the Cuelts alfo, then they anoine her mouth with hony, and covering her eyes with a vail, lead ner to all the doors of the houfe, which they bid her ftrike with che r ght foot.

Religio Ruft,.

Th: R,fican, ufe many ftange Marriage-folemnities. The rum ad $\mathbb{E}$ )n. Prselt av g a buok open before hisn, fings with a loud voyce Caytreum. one of Davis t falmes. And then taking hold with his band on one of the Bridegrooms curled locks, Ipeaks to him after this foit. Teil mre, O Bridegroom, brother, friend, Wilt thou bee this loung, womans husband, Whit thou lometimes beat and cuduel he, \&c.

Here the Bidegroom folemnly procetts ro dn the effrce of a good man. And then turning his fpeech to the B ide, he asketh her, if thee be futticient for a husband (for therr Maids of ten, and $($ l venyeais old mar y) Will fhee have a care of the houfhold affars $8 \mathrm{xc}$. whici thee affirms. Then the Prieft puts on either of tbeir heads a Gatland made of Boughs, in the circumference whereof is wricicen in $R$ uffe letrers, Increale and multiply. While he doth chis, man. wax candles are lighed, and a bowl full of Mead is then giver to the Prieft which l ee drim ali off to the new coupled at one draugh, and they cheerfully pledge him and then return him the cup again.

Arrer many prece ing cereminnies, the B idegronm taking

G Fletcher Rutit: Come micintealth c. 22. the $\mathrm{Br}$ de by the hard $t$ ey go on $t$ gethes with cheir trends after thrm rowards the Church-porch, where hee is merby $I$ me wich pors and cups in cheir hands full of Mid (ithe $R_{4} \int f$ proper wine) where the Bridegroom rahe h fift a $\mathrm{C}$ ark orlicte cup full in his hard and drinketh to the B.ide, who opening her hood or vail beiow, futceth the cup to her mouth urdernearb 


\section{A Theatre of Political Flying Infects.}

neath it (for being leen of the Bridggroom) pledgeth him

again.

The Romans in the Nuptial fupper, gave the new married Ovid.l 4.Fa. couple the juyce of Poppy tempered with mik and hony. It um.

The Ancients did ufe hony in all their Sn eet. meats, as wee Ad. I unes. do Sugar, indeed they knew not what Sugar was.

The Romass ufed hony in their firt fervice at cheir feafts, as Fu!vius Uro alfo in their fecond. And indeed formerly no kindes of mear, Gaus. but were with the ufe of hony made more acceptable.

Pitbageras ufually fed on hony, and Hony-comber, becaufe Lilii Greg. they were prepared without mans labour, and were a kinde of Syrald. Symb. heavenly food.

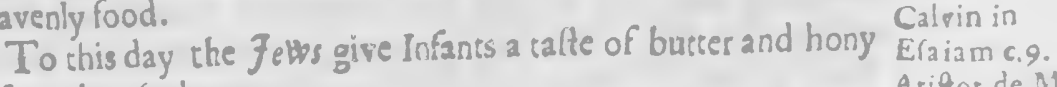
before they luck.

Among the Iliriass was firft of all the ufe of Mead, which rabilibus attin Arisforles sime the Greeks were fcarce acquainted with. Icultat.

\section{CHAP. XXIII. \\ Of Tree-bony.}

THere was anciently, and is ftill Tree-hony, as well as Beehony. And this Tree-hony is of two forts, either a plentifull hony-dew, whichmight bee gathered; or elfe fweet faps or juices diawn out, or concocted from feveral forts of trees and fruits, to the ronfiftence, tafte, and likenefs of hony.

Of the firt fort it is reporied that near the Cofpian fea, there Mr Anton。 are plenty of trees with leaves like Oalks, yeelding much hony, Cocsii sabel.? but it muft rayes thereof qu ckly corsume, and wafte it.

In Arabia Nabatbea, they gather fiony plentifully of the Diodc.Sic.Bib. Trees, whicn chey call Wild hony, of which, mixt with water, liotholo 59. they ufe to drink.

There is a Tree called Oscbus in the vallies of Hircania that L. Veruh sent. dilliech havy io the mornings.

7.6 .512$.

In Lidia there is plenty of hony gathered of the Trees of Arift de Mirzwhich the innabitants make loaves, or lumps of fuch hard- bil in cui.

$X_{2}$ nefi 
aels. that withour many blows, they canno: bee broken.

Monffet Thea. The inhabitants of Mount Libanus ofpread hides under the tru n lole E.

1.1.e.5.

J. Acoftans trees, and then thake and beacthem, and after gathei up the honv, which they referve in earshen pots.

sursil and mo. ral bir? of che

Iodies l, fo

s.:3.

The Maguey is a Tree of wonders, it yeelds Hony, Water, Wine, Uyl, Vinegar, Syrrup, Thred, Needles, and a choufand aiher things. It is a cree which the Indians efteem much in new Spoin, and have commonly in their dweilings fome one of them fur the maincenance of life : I: grows in the ficids, and hacts. grear and large leaves, at the ends whereof is 2 ftrong and Tharp poins which ferves to faften litele pins, or to fow as a needle. Aid they draw out of this leaf as it were a kinde of thred which they ule. This liqoor being lodden, turns like Wine, which grows to Vinegar, fuffering it to fowre, and boyling is more, it becomes as hory, and boyling it half, is ferves as Syrrup.

Hack'nits

Below by the root of the Mague is Tree, the Indiars make a Vuyages firt hoie, whereat they take out suice a day a certain kinde of pare lob.Hort. liquor which they reeche in a great kectle, unill the third part Hen. Huwks is id. bee corlumed, and then is waxeth thick, it is as fweet as any hosy. It is not fo fweet as the hony ( faich another) of Bees, but is is betier :o be earen with bread.

Fernand CopIn andabout the City of Therrifititan, befides the hony of iefela,2.relati. Bees, is bony of the Canes of Mlsiz, which Canes yeeld very cir aposd Mpa.

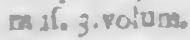
Herrera decad. 8.J.g.c.X. much hony, and an iweet as the juyce of the Sugar-cane.

In Saritia Cru,e,and the Country about it, which is in the Province of $\tau_{\text {arkisen }}$ grow fweet Cunes, of which they make very good hany.

The frui: of the Palm-erees growing abou: Fericbo, being trod-

Geor. Cedrens hifh compend. Bedade bnd. be:sc. I 4 .

Barcn. Anand Eccler. isia. den and prefled out,yeeld greai quanticy of hony.

There grow trees in Palcfina with broad and round kaves: of a mi:ky-colour, ard a hony salte, very brittle by nature, which they earsubbing them in their hand. This a certain BMhop, called Archu'gsus, who had wificed the Holy-and, luppoleth to be the wild-hory that $\mathcal{F}_{0}$ br Baprif lived of un the wildernets. Injor Pe' ufior But othess fay, li was a moun ain-hony made by wilde Bees, 152. 1.1.

Treophilin Eong: Mats 63 . bitier, and unp'eafant to the pallat. Tbecpoilas wilde hony was made by wilde Bees in trees and rocks.

They ger ethe Palm- wire afcer this furt in Conge, they bore a bole 


\section{A Theatre of Political Flying Infeets.}

hole near the top of the tree, whence flows a liquor which they Iarric. Thefanar. receive into pors faftened underneath, at firft is is in tafte and $\mathrm{CO}^{-}$indicur. lour like milk, it quickly fourech.

In Cranganor they make hony of is after this manner, within Novus orbirs three dayes (for after of its own nature, ic proves vinegar) they lofephus Indin boyl it in Caldrons, or Kectles uniill swo parts bee walted, and cus. then it is very fweet hony. Of this hony mixed with water, and purged twenty dayes rogecher, they make an excellens. fweet wine. I might fpeak of the Indian Palm, or Coso-sree, which likewife yeelds hony, bat I will adde no more.

\section{CHAP. XXIV. \\ Of: $W_{a x}$}

XT Ax is either naturalor artificial, the natural $W_{2 x}$ is the grols part of the combs, containing the hony and Bee-bread, lometimes the Seminaries for generation. And this is either Virgin-wax, or of a courfer fort : the Virgin-wax is that which is made by a fwarm, or a ftock new driven, not that only which is made by the younger Bees, as. He llerius, for they work altogether.

This is ealled by fome Propols, as Aldrovand, obferves out A etuas. de of ACtuarius. And Scriboniw Largw, It might bee expected, compol:modo thas I fhould Speak fornewhat of Propolis, Commo/ss, Mity, and Piffsera, uied anciensly in Phyfick, and luppoled to bee made by the Bees. But I can finde no a greement among Philolophers, nor yet Phy trians what tbey are, andian certain that they are not what Ariftotle, $P$ lin, and ochers determine them:to be, and therefore l. will leave the difcuffi: $n$ to o:hers. Only in a word, Mity faith Ariftotle, is the black drofs of wax of a Pharp Ariftede hift. fmell, I fuppore be means the feces of the wax when it is melt- anim l.g.c Gt: ed and ftrained; Propalis leems, faich Ssaliger a uranflatuve fir- Scalig.eom, in. name of Aivily.

Helles ius l.6. Intitur Chy: rurg.c.I. 
ew takes it for the dreggs of the combes, but amifs, faith Monffet, and yes be would have it to be Hive drols, but whether of a Swarme or a Stock he declares not; between which is a great differeace; Andrees Bellusenfis, the filth or drols of the lides of the Hive; I fubferibe to Syloaticns; Propolis is as much as Juburbe drofs, with which the Bees faften the skirts of the Hive to the board; it is not faith Mouffet now to be found.

Waxe is thus made by the Bees; thesy creeping upon the Flowers with their fangs and tongue, os Ariftotle and others fay, extract a gummy and vilcuous matter, which they receive with their fore-feet, and rubbing them on the thighes of their hindfeer, ,here faften it, very little at 2 time, and icarcely vifible.

Moufet faith, the burden is of the bignefs of a lentil on either thigh, and that it is of divers colours, according to the nature of the Flowers, yellow, pale, red, Saffron colour, white, black, \&cc. buthee and many orhers were mittaken, taking Bee-bread for Waxe.

Diolcor.l. sie. The beft Waxe is fomewhat yellow, fat, pure, odoriferous, T. and expreffing in fome fort a fcent of honie; Diojcorides comPlin.lib.3nes 4 mends the Pontick or Cretan, Plixy commends the Punick, and $\boldsymbol{i}$ is called Punick, (aith Iacobas Dolecbampius, becaufe it is the whire?t.

Artificial Wax is that whereco the perfection of it the skill and induftry of man is required, and this is variounly perforJobennes Aag med; two waies are fer down by Anglic us, FIrlt, that the licus in rofa Wax ihould be often melted, every time taking new water unanglice, lib. 3. il it be whice. Another way is thus, that when it is diffolved as 1 in the water by the fire, to dip into is a Glafs vial, or veffel elean rinfed, and that which sticks to it let it be dried in the Sun, and Moon; and this fo long cuntinued until you have gathered up all the Wax, and then fet it abroad in the open air, for it grows whice by the force of the Sun (that I fay nothing of water) becaufe lo the hony is taken out of it, and thole parts expire by whore thinners the colour is made.

Waxe as it is newer, fo it is better, for ir is more odoriferouss, puerer, and aps to cake impreffions, Waxe is worft at the botcom, bett at the top, fo that it be not frothy.

The Bees gacher Waxe all the year, from the blowing of the

Mir. Remnatis. Willow rathe Inie. 


\section{Theatre of Political Flying Infects.}

Inold Waxe Saich Arifotle, there is bred imall whire Crea. wures, the leaft of creatures, called Acari, in regard of the fmallnels, not devifible, I fuppole he means Mites, which are bred alfo in many other things.

The Kingdome of $C$ bandecan, watered with the river Ganges, $F_{r_{a}}$ Deif. Feris plentifully fored with Waxe, which in abundance she prople nandus fiode in the Woods, and therewith fupply Beng ala, and a great part of India.

The Livoniass knew not the ufe of Waxe, and therefore Aloyfius Cado. preffing out the hony threw it away; Cadomast us reports the malus. like ignorance of the Africans in Muritaria.

From the Coalt of Malindia, near adjoyning to Madagalcar, there is brought one thoufand five hundred $T$ is of Waxe yearly to Indic.

Teculetb a Town of Hea feadeth Waxe into Portingale; and lo. Leo, lib. 2 to Temfttbne refort thips from Portingale for Waxe.

In $\dot{F}_{e z}$ on Mabomers Birth-da y the Schollars of every School, Idem, lib. 3 which are two hundred, celebrate a Fealt, when the Fathers are bound to fend each man a Torch unto the School, whereupon every Boy carrierh a Torch in his hand, fome of which weigh thirty pound; theie Torches are molt curiounly made, being adorned round about with divers fruites, of Ware, which being lighred betimes in the norning doe burne till Sun rifng, when the folemnity ceafeth. This day ufeth to be very gamful unto she School-mafters, for they fell the remnant of the Waxe upon the Torches for above a hundred Duckers.

The Pe, frans in old time, and ailo the Africans had a cu-Funera'i anfome so wrap up in Waxe sheir dead, tbat fo they might pre-tichida Tho. ferve them for a long time.

The Romans in the Burial of a Senator or chief Officer, bad Goodwin, cercaine waxen Images of all his Predeceftors carried before Room,antiquit, him on long Speares.

Wax was much ufed anciently, to make the Images of eminent peifons deceaied, as alfo in our daies, which by many circumitances ( as appears) were borrowed of the Romans; who when the dec:afed Emperour was to be confecrated, the whole Cirygave over all exercifes, as if it had been a Feltival day; Firft, they burned the dad Body with fumptuous exequies, and then they made an Imige of Waxe as like as was polfible to the 
deceafed, and fet it in the porcb of the Pallace upon a great bed of Ivory, placed atof, and ccvered all over with cloth of gold; this Image lay pale on the Bed as if it had been a Sick Perfon, about she bed fare a great part of the day all the Senarors cloathed in black, and on che left fide the Ladies, that in regard of their Husbands, or Fathers, were moft illuftrious, and none of them did wear any gold, or any other ornament about their necks, but were all cloarhed in pure white garments, and 'by their countenance feemed very forrowful, and they continued thus in this guife feven dayes; but every day the Phifriars came to the body, and made thew of feeling the fick Partice pulfe, and alwaies reported that he grew worle and worfe, antil in ethe end they faid he was dead.

As foon as they had declared him dead, the molt noble and proper young men of the Order of the Senazors and Cavaleers lifted the bed on their houlders, and carried it by the Sacred way into the ancient Market, where the Romane Magiltrates were accuftomed to lay by, and renounce their command and authority.

In this place was ereated a Tribunal of Wood, which reemed to be of 'ftone, on which was framed a certaine edifice, ruftained on every fide with Pillars, and variounly garnilhed with Ivory and Gold, on which was laid another Bed with ornamenes of Purple and Gold woven together, and abous -it, were the heads of divers Sez and Land creatures; now in this Bed they placed this Image of Waxe triumphantly adorned, which they had brought froin the Pallace, and there food a very fair youth with a fan of Peacocks Feathers to feare away the Fles, as if the Emperour flept.

In the meane time while the Image lay there, the living Emperour, the Senate, and their Wives drew near to the Bed, until they were all met together, there the Ladies fate under the Porch, but the Senators open; on both fides of the Market were fet up Scaffolds to afcend on, which on one fide were a Quire of noble yourths, all parricians, and on the fide a Quire of illultrious Women, which fung Hymns and other Songs in honour of the dead, with fad and mournful voyces. But 1 mutt play the Procruftes with this Difcourfe, and referre them that defire to *know further, to Dion, or Hciodion Greek Hiftorians. 


\section{A Theatre of Political Flying Infects.}

\section{CHAP. XXV.}

\section{Obfervations and Difcourfes Hifforical, and Fabulous.}

REfore the batrel of $\dot{P}$ bafilon Bees lighted on the Altar, and alfo Rotenus RoBon the lhips, prefaging Pompies overthrow; and therefore man. Antiq. when in the Army of Bruius, there ferled a fwarm of Bees, the 1.3.c. . Souch-fayers bad him to thift his Camp, left hee thould re- Dion Rom. ceive lors and damage in that place.

Appian 1.2.

All the Statues of Antoninus Pins in Hetruria were fil- Iulius Capito. Jed with (warms of Bees, which were ominous prefages of his linus. Empire.

It was ever efteemed as an ill omen for fwarms of Bees 10 Cornel. Taeilight in places where they were not accuftomed, and therefore cus $1,12$. repnrted as a prefage of the deach of Claudias, thax a fwarm of Bees ferled on the Capitol.

One fpeaking of the prodigies that did precede the batcel of Canna, faith, that fwarms of Bees lighted on their Enfignes.

Silius Ital licus.

\section{Nee den $\int e$ trepidis apum fe involvere nubes \\ Ceffarunt Aquilis.}

Among the many Prodigies ominating Brutus's deftruction, Appian de bel. fwarms of Bees lighred in his Camp. Swarms of Bees fettled lo civili ha. in the Camp of $D_{1}$ usus when bee foughe prolperoufly at Plia. Arbala.

Ambrofe fleeping in his fwadling cloaths having his mouth Baronius open, a fwarm of Bees came and fected on his mouth, which the Annal.Ecelef. father and mother walking by, forbad the Maid that cended him t. so. to brufh off, where a while continuing, at laft they flew up into Cicero divina.

2.Val Mas.
the air, untill they could bee leen no more.
Plate feeping in his fwadling cloaths, the Bees brought I. Sarisberode hony to his lips, foretelling the fingular fweetnefs of his elo-nugis curial quence.

I. I. C I 3.

Hiero fometimes chief Magitrate of Sicilia the fon of Iuftin l.23. Hieroclitus, a Noble-man, who drew his original from Celus, 1.Sarisberienan ancient Iysant of Sicily, but his mothers Acck was mean Gs denugie 
and contempibe, for hee was born of a Maid-fervant, and therefore as a difpar ! gement to his fathers race, was calt forth, whom the Bees (waneing all humane help) fed with hony, which being known, the tather by the Augurs counfell received again, and biought up as the Heir of the Kingdome.

Elizn l.a c.ij efliar cirng Anterior, repoits that the inhabitants of a cermin City in Crcea were forced to forfake their dwellings by cerrain Bees called Cbolichoides, which did miferably molet, and ttirg chem.

Willer, Tyr. The Cirizens of Marra, two dayes journey from Antiocb, archiepil, tr.t. being beliteged by Goufrey Duke of Bullen, amorgother things lib.19. \& whicn they threw over the walls to drve away their enemies, Rzimuns. de caft over Hvesfull of Bees.

$A$ ziles Hid.

Rrancrum

Appian, de bello Mithrydat.

Bonfin.l.4.desad.3.

Luiktus Army befieging Tkemifcyra fcicuate on the banks of the River Tkermodion, and by Mines feeking to overtbrow the wills, the inhabirants opened them above, and threw in Hives of Bees among them to their great trouble and vexation.

When Ams a bib the Gea: Tuk brieged Alba Greca, etie Inhabieants, befides o.her things catt Hives of Bees among the $T_{4} k$; whereby they were grealy annoyed.

Vitichindusl.r A Cap:a's of the Emper. u.s be ng b fieged by Gifelber gef.Sas. the King of Lorrain, reftrained the en mies when they entred the place, by cafting riv s of Bees; for the horfes being earaged with their $A$ ngs, overthrew their Riders, or were altother unierviceable.

O.orius de re. Lupus Barige warring with the Mors in Mauritania, and bus Emis.1.8. befreging a Town called Tornlt, the inhabitan's being at the latt calt, threw over the walls abundance of hives of Bees, fet on fire, wherewith the Portirg Is vere to bume, and Atung. that they were forced to give over, with the woundirg of their $\mathrm{Ge}$ neral, and many others.

Saidas,

Ge ergius

Brawn 1.4.

arbiun prec:

gotsist.

Cozenours and Cheaters were thus anciently funithed, they divefted the guilev perfen of his cloaths, ard then anointed bim wich hony ail over his body, and fet him in the Sun with his. hards and feet falt bound, that by many reirerated firgirgs, and the Suns hear, chey might icccive a death,volthy of their life.

In Sivil a Ciry of Spain, if a womar her s her tusband Thee is carried on an Afs chruugh the City naked from she gi:die-Ated up a 


\section{A Theatre of Tolitical Flying injectso}

up:wards, and being firt ano:nzed with hony, befijes oriber de?pights, and injuries. Fuffers not a hitcle mile.y fro.n the Bees, Warpes, and Flies that inoleft and fting her.

Marcus anold man in the reign of Conftartine, overthrew Theotdores an Idol Temple at Aretbusa, and was taken under 3 ulian the 1.3.67. Apoftate, and firft fcourced on his naked body, and afeer otner punifhments, in the laft place put in a basket, being all over anointed wich hony, and fo fet abroad, whom the Bees(thinking bee had robbed them) fung therefore to death.

Hermonay the fon of Amyantr, and Lyfodice being a childe, and coming to the Hives to rob the Bees, was killed with their ftings.

Onefilus the brother of Gorgus King of Salamis in the llie of Cyprus, fighting againft Astybius a Perfían General, was nain, and his head cut off, and hanged cver the gates of $A m a^{-}$re.l. 5 .

t $k$ w f r um, a City in the fame Ifland, which hee had fomerimes before befieged; into which when it was empty, a fwarm of Bees entred, and filled it with combs, this is repor:ed as a Prodigy (and dorh not prejudice the cleanline is of Bees) tor confulting the Oracle, they adyiled to take down the head and bury i.

Livonia is replenithed with ftacely Woods, and thofe fur- Purchas Pilnifhed with induftrous Bees, which fornerimes being nume- grims 3.part, rous, are pus to hard Ihifse for habitacions. Mr. Barkley an Englith $1.3 . c 20$. Merchant, did in ose of thefe Woots ear hony our of a mansskull, wherein a fwarm of Bees, were, and bied as it hanged.

lis is reprorted that in the Sepulchre of Hippscrates, the Prince of Phyfrians, for a long time a fwarm of Bees lived, and wronght hony in is, and that this happened extraordinarily, is concluded, becaufe that Nurfes anointing childrens mouths near the grave, wrth the hony eafily curend them.

Dionifins the fon of Hermectatis fwimming over a River upon his horft, his horle was mired, and could not bee pulled out by any mieans, hee leapod off his back, and gorfafely to the Atliancarar.hin 1.12 .6 .92$. bajk, and fo forfook the horfe as no longer his : But the horle followed after, and neighed, whereupon he reiurned, and when he la:d hold on his Main to mount up, a lwstin of Bees encompaffed his hand, which hung on his siane a prefage of his furres cCiszand and Erop ire. 
164

Pafanias in

Beoticit.

Theocritus

I s. nurrat.

Eidyl.7.

\section{A Theatre of Political Flying Infects.}

The Tropbonion Oracle was thus fcund out: When as a year or two together, there was no rain, fome were lent from every City to Delpbos to implore help. To whom defiring a remedy for the drought, Apollo commanded them to go to ILabadea, and leek a remedy for their evill of Tropbonius. Going therefore to Labadea, but not able to finde the Oracle. saon one of the Ambaffadors an old man, when he had efpied a fwarm of Bees, refolved to follow them whitherfoever they went. When therefore hee faw them flying to a Cave, hee entred in, and underftood that place was the Oracle which they lought for.

Comates feeding the flock of his rich Mafter in Sicily, was fomecimes accuftomed to offer fomewhat of his Alock to the Mufes; which when his Malter knew, hee reproved him very Marply, whom Comates intreats not to bee angry, for by the Mufes help there fhould be a large remuneration. Go to, faith his Mafter, let us make erial whecher the Mufes willfeed thee, and incloled him in a hollow tree, and there left him to perifh with famine. And at the years end recurning, found his fervant alive, and well, and many Hony-combs abour him, for the Bees by a hole had entred into the tree, and maintained him.

The Bre. mafter being ablent, one came and Atole the combes Felop. Fab. 89 out of the Hive, who afterwards returning found his Bees plundered, and while he tood ftill a while to examine and cot fider concerning the aurhor of $\mathrm{it}$ : The Bees came home from work and finding their houfe robbed,and him Itanding by,did fal upon him, and cruelly Aing him. To whom hee thus fpake, On you wicked creatures, you let go unburt bim tbat robbed you, and punifp mee itat am careful of your lafety.

Melifa one of the Oread Nymphs finding Hony-combes in

Natal.Com. Mythyolog, b.s.c.81.

Sands relat. 1.4.

Tetripius: Peloperiefus, invited her fellows to : afte thereof, with the fweetnefs where of they were fo ravifhed that the Grecians called the Bees by the name of that Nymph.

Jacolus Sanrosarius that excellent Poet, hath his figure cus to the life in Merge Bira (near Naples whete he lived) from whole mouth the Bees do leen as it were to fuck hony.

Livy doch relice that there was found two Cr ffins of lead in 2 tomb, whereof one contained the body of King Nama; being fome four hundred years after his deach; and the other his books 


\section{A Theatre of Political Flying Infects.}

books of facred Rites and Ceremonics. And that in the Coffin that had the body, there was norhing at all to bee feen, but a litelle light cinders about the fides, but in the Coffio that had the books, they were found as frefh as if they had been but Dewiy writien, covered over with yratch candles of wax, three or fourfold.

Agefipolis a King of the Locedemonians dying of a Feaver Xencpion near the City of Clyntbia was preferved in hony, and fo carried de rebus geftis to Sparta, where hee had a royal Euneral.

Claudiss Cafar had a Hippocentaure, a Montter, parchorfe, par bull, broughe ouc of $E_{g} y p$ : in hony, which $\boldsymbol{P}$ liny faich he faw. $\boldsymbol{C}_{\mathfrak{x}}$. Rhod.

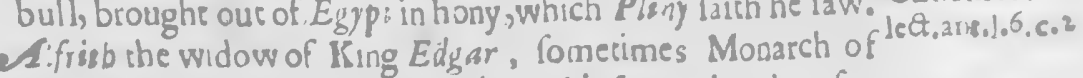
this Ifland, traiterounly flue King Edward his fon, that her fon Rob.GlocefEtbelred his brotber law might (as hee did) fucceed him. trenfis.

Some cen years of age was hee when his bro:her Edward was flain, and hee out of childilh affection wepe for him biecerly; which his mother extreamly difliking, being author of the murther, onely for his fake, molt cruelly bear him her felf, wich a handfull of Wax-candles. So "that hee would never endure Vit.S. Ed.apud Wax-candles. But another Writer laith that Erbelred would Ranulph. never endure any Wax-candles, becaule hee had feen his Ceftren.1.s. mother unnercifully with them, whip his brother in Law, $\mathrm{K}$ :ng Edward, either report may bee true.

Now the Sword and Scepter is taken from the feoss, inftead of other penalcies they in na:ure of the crime. Thus the Adulterer fatisfietb for his hot torf. luft in cold water, wherein hee is enjoyned to fit fome Wincer dayes; and if the water bee frozer, the Ice is cur out, and hee fe: the ein up to his chin, as long as ail egge is roalting. In Summer time hee is fee naked in an ant-hill his nofe, and ears itopped, and after waheth himfelf in cold water. If the penance feem lighter, they enjoyn him further to run. through a fwarm of Bees, and when the fwallirg of his body through their ftinging is abared, he mutt do ic again, and again, according to the meafure of his off:nce. It hee hath often that way offended, hee is bound to indure that penance mary years.

$H$ unding the 23. King of $S$ reendland, upon a falfe report of Kranszios, his brother in Law $H_{a}$ dings deatk, King of Dexmark, invired all his Nobility to a fumpruous feaft, to conclade which, hee $\mathrm{X}$ ? had 


\section{ATheatre of Political Flying In fects.}

had provided a very large veffel of Mead, of which hee drew out himfelf to them unitil they were all drunk, and then in token of love to his fuppofed dead friend, plunged himfelf into the 1.Magnus hift. veffel, and fo was willingly drowned (but ridiculoufly and Sueonum. foulifhly) (ome applaud and prefer him therefore, before many heroical Greeks and Romans.*

Plin. Nat.bit. Hoftilia is a Town in Italy, warered by the River $P_{\theta}$, the 1.21.6.13. iahabitants whereof (when meat for Bees grows fcarce about them) cariy their Hives into Boats, and by night convey them up five miles againlt the Aream. In the morning the Bees go forth to their work, and fo do they thife places, afcending up the River, till by the finking of the Boat, they know their Hives to bee full of hony, and then return they home, and take it.

What is the reafon why among the Sarmalians there is Ambrof. Leo plenty of hony, and in Africa fmall ftore of Bees? And hee
Problem. 180. flowers, which in a fow dayes after the fnow is diffolved, embroider all the fields, and the many Fountains and Rivers wherewith they are much delighred.

Whereas in $A$ frica, the fruits and the flowers by the violent heat are quickly withered, and the waters are fcarce, fo that of neceffity thofe things being wanting wherein Bees delight, there mult needs bee few, or in fome places none at all. His reafon is not worth an anfwer, had hee been read in hiftory, bee might have learned the contrary. Fo. Leo, $\mathcal{F}_{026 n}$ dos fantos would have (befides many other credible Aurhors) convinced him of the plenty of Bees in Africa. But no wonder if hee were a Atranger abroad that was ignorant of Counerits near home.

Hee affirms that in Germany, France, Britain, Italy, there are none, or few Bees, bicaule (if you will beleeve hım) there are few rrees, fruits, waters.

Andrew Butrel In Angola they have great fore of hony, which they thus in Purchas Prigrims fecor:d pare 1.7. c.3. procure, they hang in the top of the Eliconde tree a hollow peece of wood, or cheft, which the wilde Pees being there numerous, quickly finde, and laborioufly fill once in a year with hony and wax; which the Negroes then take with lmoke, rewarding the indultrious creatures with robbery, exile, death.

It will not bee altogether impertinent to give you a defcripti- 


\section{' Theatre of Political Flying Injects.}

an of thistree, with which the Bees are more delighted than any other. The Eliconde-tree is very tall, and exceeding great, fome as big as twelve men can fachome, fpreading like an Oak, fome of them are hollow, and from the liberal skies, receive fuch plenty of water, that they are hofpicable entertainers of thoufands in that thirfty Region. Once have I known three or four thoufand remain at one of thofe rrees, and thence receiving all their watry provifion. The Negross climb up with pegs of hard wood (which that fofter eatily receivech, the fmoothnefs, not admitring orher climbing) and I think that fome one tree holds fores tun of water. This tree afforde no lels bounciful holpitality to the back, than beliy, yeelding (as her bel'y to their bellies ) her back to their backs, excepring that this is better from the youngertrees, whofe tenderer backs being more feafonable for difciplioe, are foundly bearen for mans fault; wherice came the firtt nazedneis, whereby one fachome cut from the tree, is exrended in:o twenty, and is prefently fit for wearing, though not fo fine as the $\mathcal{F}_{\text {uzarda }}$ tree yeelds, which yeelds excellent cloath from the inner bark.

This eree is al wayes green, of a frange form, efpecially in the Linichoten 2. branches tha: grow very high, and caft down very fmall threds, Bout. which touching the earth do bring forth roots, from whence orher plants or trees do fpring forth molt abundantly in greas numbers. By like beating of their $\mathrm{Palm}$, they make Velvets, Satrins, Tafferies, \&c. But I deviate too far from my fubject.

The burning of Waxen-candles on Candlemafs-day had its annot. in x.lis: original from the Roman Sacrifices called Februals.

Bears are much cormented in their eyes, which is a principal Marcion. caufe why they fo much defrre to eat hony out of the Hives, that being prickt, and fung with the Bees, their throat, elpecially receives a phlebotomy, or blood-letring, for they have no better remedy to eafe their brain and eyes burdened, and overcharged with humo:s.

In the Inand of Seylan are certain barbarous people called Texeira $\ell_{0}$ t $_{2}$ $P$ acbus, they live naked in the woods and thickets, eheir principal ${ }^{0} 35$. food is Dears fiefh, where of th re is great abundance, which they thoot and kill with their arrows, and cutring them in peeces, falling the crunks of old hollowitrees wish hony, whersof they 
have plenty, then they pur the fleth thereis, and let it remain there rill times of neceffity, and then eat it, conferving it onely in the hony, withouc any corruption.

Hackluit In the Counery of Besin on the coatt of Africa, is fuch plenVoyages, 2. ty of hony, that the Natives bring to the Englifh trading there, part of the \& Volume. earthen pots of the quantity of two gallons full of hony, and hony-combs for a hundied fhells.

Jo2on. dos

Santos liaro About Sofala, and generally in the Oriental Eibiopia, breed permeiro da They make a ball of clay, and ftck it in the walls or tiles of Ethiop. Orient their houles, with many holes after the falhion of a Bees, or c.23. Wafpes-comb, and in every bole shey put a Worm or Maggor, like thole that breed in Cabbages, fome green, ochers black, otbers white, others gray; fo that they are not all of one kinde, or cal; but whatfoever they finde, they take and carry it unto the comb that they have made of clay, and in every hole they puta worm, and Ctop it up with frefh clay, and lo inclore all the worms in their feveral cells, and there within they generate other $Z$ ang aons, (or Bees) (underftand by generation of others, onely their tranfmutation, whereby they are others from what they were, and the following words import as much ) with legs and wings, which when they are perfected, ear through the clay, and come forch, and Bye, and after they are grown great, they make a like brood. So that of Arange children of divers calts or kindes, they make proper children. A thing, faith the Author which much amazed mee. But whether thefe malse hony, or are any wayes beneficial to them, the Relator is filent; but being a general practice, it is morc than probable that they are fome way proficable.

Varro, Great is the profit of Bees in fome places, Varro reports of two brethren in Spain, who had left them by their father a little Farm houfe, and about an Acre of ground which they replenithed with Bees, and feldome made lefs of their hony, then ten thoufand Seftertia yearly, a prodigious, and I think unparelleld inereafe.

Menna a Hermite in the Province of the Samniles, bad for his fubfitence, only a few Hives of Bees, which when a Lo gibard thief had Atoln, he was poffett of the Devil, till Menia by his prayers freed him: 


\section{Theatre of Political Flying Insects.}

Herälius the Emperour having Warre with the Perfacis, Baronannal.' and wanting mony (the people being before impoverihed by Ecclef. to 8 him, fent one Nicet as to Alexsander the Patriarch to borrow of him the Treafures of that Chuich (as he did of others ) who notwithftanding his refufal, carried away all he could finde but only one hundred pound of Gold; but while they were going away with it, there were certaine men thatbroughe, as a Prefent." feveral Pots of Hony (which by a Miracle) to fupply the $\mathrm{Pa}$ sriarks neceffities, when they opened them they found all turned into Gold.

I fublcribe not to fome Papilts, who pretend there is a Valfridus, great Majefty in their Holies (whole-lyes) from the burning of Strabus, lib. 28 Waxen Candles, and that waxe candles for that purpole ufed, in vita S. Galliw cannot without great Sacriledge be taken away.

A certaine Country-man ftole a waxe candle from the Altar; and found it curned into a Itony hardoefs, whereby melting, he arknowledged his guilt before many that Aood by, and the waxe candle recovered his former foftnefs. I might be large in fuch Legendary relations, but thefe are enough, if not 100 many.

\section{CHAP. XXVI. \\ Obfervations Phyfecal and Chyrurgical.}

He ufe of Hony with Bread to old folks makes them live long,for it keeps and preferves all che fenfes found and entire. It is reported that $P_{\theta}$ llio being asked by what means men might live long and healthy, anfwered, by anoynting their outward parts with Oyle, their inward parts with Hony. The fruie therefore of the Bees, faith Ambrofe, is defired of all, and is equally fweet to Kings and Beggers; and it is not only pleafing to Princes, but alfo proficable and healthful, it fweerens their mouthes, cures their wounds, and convaies remedies to inward ulcers.

Democritus continued his life with the frequent eaing of Hony; and bread wish Hony was the Pythagorians mear. Z

Ariste. 
Aliheneus dipnofophif. 1.2. c. 3 Gorap, Becant Niloftop.lib. 3

Ariftoxerus faid, they might live long without Difeafes who always fed of it at dinner.

Goropius commends the hony gathered of the Heath, before the sponifb hory gachered of Ladarum, and divers kindes of Coftus, asd shat becaufe it is fweeter, and not fo hot as the hony; gathered of Srechados and Thyme; it opens obftructions, at tenuates grofs and rhick, cuis and cleanfech vifcuous humours, and is efpecially profitable for thofe that are troubled with the Splecn.

Plixy moft of all commends that hony which the Bees gather in the Dogg-dayes, almolt thircy dayes after the Solttice, for faich he, after the rifing of every Starre, efpecially the greater ones, or the Raine-bow, if fhowers follow not, and there be a warme dew with the rayes of the Sun, Medicines, not bony are produced, heavenly gifts for the eyes, ulcers, and bowels, which if ic be preferved, the Dogge-ftar being riren; and if by chance is fall out in the fame day there be a riling of $V$ enus, or Fupiters or Mercury, chere is no fuch lweetnefs nor vertue in the luppofed heavenly Nectar, to keep Mortals from Difeales, though. orherwife deadly; bue we have licele of this in our Country. where the Hony-gathering is then almolt frnifhed, but that which is found in the lower parts of the combes, and fome lircle that is not fhut up with waxen covers.

Hony is hot and dry in the fecond degree, wherefore Gales forbids is luch as were Hectical, have a Feaver, or the Jaun dies, and young men; but commends it very much in cold ef feess, and prefcribes itco fuch as had moylt ftomacks, for moderarely eating of it, it wonderfully nourilher $b$, and cauferh both good colour and conftitution.

Hony with age or long boyling becomes bitter; it gives life to Wine when it is fat, Flowers, Fruites, and all fimple and compound Medicines by mixture of it are preferved from putre: fakion.

Hony corrupts by crumbes of B:ead, and therefore shey that fell hony, are carefulleft children paffing by dip their bread in it, and fo it is tranfmuted into Ants, or litcle Crearures like them, if

Raracelfus, Hippocra: we belecve Paracelfus.

Hony mixe with other things nourifheth, and makes a good colour, bur earen alone atcenuares rather chan refrelbeth, for it 


\section{Theatre of political Flying Infects:}

Frovoketh urine, and purgeth too much.

Hony warmes and cleares Wounds and lilcers, atceriuates Galen 2 and difcuffech excrefcencies in any part of the body.

Avicen.

It is very effe, Aual to produce hair in baldnefs, for Qusotidian Galen, Agues, efpecially oyle of hony diftilled.

Diftilled water of hony makes a fmooth skin, provokes uriae, diminitheth heat in Feavers, eaferh the obftructions of the bowels, quencheth thirf.

The falt of hony of all Corrofives is leaft painful, and molt energetical, and therefore in the Alefh of the yard by Chymicks, and expere Chyrurgians efpecially commended.

The Epicures who chiefly ftudied healch and pleafure; did eat continually Ambrofia, which confifted of a renth part of Tzerzes: honie, as Tzetzes reports, concluding that the daily ure thereof would prevent griefs, and keep them fice from Difeafes.

Hony infufed warme by it felf wonderfully helps, exulcerated Galenur: ears, efpecially if they calt forth ill favours, as alfo their fingings and inflammacions.

Hony, Butrer, and Ople of Rofes, of each a like quantity Marcellus warme, helps the paine of the ears; he alfo commends Hony, Empyricue, and infants dung brayed together in the dulnels of the fight, and for white fpots in the eyes.

The rheume or droppings of the eyes in meń or horfes ate Vigetiusis hereby helped, I have cured a Horfe ftone blinde with Hony and Salt, and a little crock of a por mixed, in lefs thao three daics, it hath eaten off a rough filme, and the Horle never complained after.

Hony wherein Bees are drowned, or Alhes of the heads of Marcellus Bees, with hony, clear the eyes; Altick hony, with the firtt Empyrious. dung of a young infant, and the milk of the Nurfe mingled rogether, and amnoyne the eyes that are dull upon what oceagion foever, but firf binde the party, for fuch is the violence of the Medicine that he cannot otherwife patiently sadure it, and the benefit is fo forcible, that in the chird day it wil make a clea: fighr.

Nothing is better for infants that breed Teeth, os in the Ulcers of the mouth than butter and hotiy; Galen preferibes only the gums to be sulidewith it, for it conducerh woriderfully to the Z 2 
generation, confervation, and whitenefs of teeth: for difficulty

Hippocran

Galenus. \&s

Cellus.

Abynzoas.

Valleriola in Hony nourntheth not only bessufe it is a kinde of nourifhment, of breathing, and to caufe fpitting, hony alone or mixed, is very availeable.

Hony boyled with Bees, or new Cheere, Aayeth a loofenefs; helps the Bloudy-flux and Chollick. But before hony be ufed is is acceffary to clarifie ir : Thus, take of hony and fountaine water of each iwo pound, contrually fcum it as it arifeth, to the confumption of the water, afterwards clarifie it with the whites of twelve eggs.

locis com!lib. 3 but alfo becaufe mixed with other things, it is a caufe that they are more cafily carried through the body; and he counfels old men to ufe it much, if they would have a care of their health, and live long without Difeales, and he afferts it by the examples of Ansiocbus the Phifitian, and Telepbus the Grammatian, who Galen lib. 3.'ce were old men, and did eate Attick hony and bread; and Galen fanitar tuend. teftifieth the fame, with often eating hony boyled, fe'dome raw, c. 4. \& c. 8 and yet $G$ alen forbids long, or too much boyling, becaufe it will make it bitter.

Cornelius Cellys reckons up boyled hony among fuch things as ftop a Celcus, $1 . b_{1}$ 2. Lask, the reafon is, becaufe the acrimony by boyling is taken $a=$ 5.3 way, which is wont to move the belly, and to diminith the vertue of the food.

The bodies of Bees taken newly from the Hives, and pow: dered, and drunk with Diurerick wine, powerfully cures tho Dropfie, and breals the Stone, opens the fountaines of urine, and heals and helps the ftoppaoes in the bladder. :

Bees drowned in hony, and fo killed, ftay vomitings, and are profitable for deafnefs.

Bees powdered cure the Wind-collick, mollifie hard ulcers. in the lips, and al fo the Bloudy-flux.

Hollerius:

Galen in Euporißtis.

Erotis, c. 6. de morbis mw. iebr.

Hony mixed with powdered Bees and fo taken, is helpful for the crudities of the ftomack, it is allo good for the ftomach.

Pound Bees dead and dry in the combes, mingle them with hony, and annoynt bald places of the head, and the hairs wil fpring: afre?h.

The afhes of Bees ground with oylegmake hair white.

Take twelve or fourteen Bees powdered, in any thing every morning and it helps fuch whofe resentive faculty is weak, fo shas ghey cannot bold their water.

Oxymel. 


\section{A Theatre of Political Flying Infeets.}

Oxymel is made of water, vinegar, and hony, now water is Mefues mingled with ir, that by long boyling that may be refolved or loofened which the windine rs raifeth up, and that it may be more readily skimmed. In a word, that the working of the Medicine, by the mixing of water might be weaker, and more eafily difperfed into the body, and hony is added to refitt the flegme.

One ounce of hony and vinegar mixed engether arifeth a certain third faculty which was in neither of them before, which is moit powerfal and certaine to atrenuate, cut, refolve shick and tough excrements, which have been bred a long time in the Stomack and Liver, and thofe that cecte on the joynts, and caure lafting Agues.

It is made thus, rake of vinegar one part, two parts hony, and twice as much water as hony; firt, let the horiy and water be boyled, and when they have been well skimmed put in the vinegar, and boyle them fill, continually skimming them, les thern boyle till there be an unity of qualities, and the vinegar be Galen. lib; 4snot raw, or crude, it is given from one ounce to three; Galen de fanitas, tusfaith, if you will make it the ftronger, adde as much vinegar as end.

hony; it drives out thick and grofs humours, and is proficable for the Sciatica, Falling-ficknels, and the Gout; good alfo to gargurize with, in a Squinancy.

Water diftilled of hony four times by a Limbicis, fo that tire hony were firf boyled, makes beautiful hair, kills Lice and Nits; the hair wet therewith doth not only become yellow, but fofter, and increafeth likewife, efpecially if it bee done in the Sun; it heals fwollen or bloud- hotten eyes, and helps the hure corners of the eyes, it is excellent for burnt places, tnott of all for fuch as are fort and tender, fo that no fcar will be left.

Is mult be diftilled in a Glafs SciH, bue firt mixe with it pure and vell walhed Sand, and make a foft fire. The firft water is calt away, the fecond is preferved, which hath a goiden colour, and red at the laft; the red purgeth out corruption in putrid wounds if they be wafhed with it, and a linnen cloct moyftened in it, be laid upon them, and when it hath purged them, it produceth fle?h.

Hony when it is diftilling is wont to fwell, and flow over when it grows hot, this is prevented when the diftillation is Rerformed by a woodden Sieve (made wisth bair ) being 
placed within the cover, fo shat it toucheth the hony.

Hieron; Re: beus, Tete $_{\text {e }}$; c. 8

Reubeus diftillech it otherwife, and adds other cautions : he faich, the water is with difficulty drawne out of the hony, becaufe it readily as the fire grows hot, afcends to the top wherefore fome mingle glals with it, orhers fand, the molt doe annoynt the Still within with oyle; but it is beft diftilled efpecially where they purpole to ufe the dregg", by wercing linnen cloathes in water continually, and fpreading them on the head and fides of the Still, and a foft fire beiow, by which the fwelling thereof is refifted, and leaving much vacuty and emprinefs in the Stsll, fo that it be filled a fifth, or at the moft a fourch part; but becaule fometimes a larger fire is neceffary, the cucurbite muft be well crufted with ciay. It it excellent for a Andernacus Catarrh,Cough, Spletn, \& $c_{0}$

dial.7.com. 2 Oyle alfo is diftilled our of bony, let hony in the combes bee pue inro an earthen velfel, and well macerated in warme Horfedung, until the waxe being feparated from the hony, fwims aloft, which being taken off, let lome Flint-ltones be mirgled with the hony, and little peeces of glafs; the firft water when it is difilled is very Rarp, and then comes the oyle. It is fingular for the Gour, and for the cure of all Wounds.

Aldr. libor, de

Oyle of Waxe is thus made, let two pound of new odorifeTaleQ. rous waxe be melted in a Frying pan, auth then poured our into a vefiel filled with Muskadine, or other generous Wine, and let it continue there until it be cold, after taken out and fqueezed vell with yourhands, and againe melted and poured into the Wine as before, and let it be leven times reiterated; and then let it be melted againe, and three handfuls of beaten Bricks pue into it, let them be well mixed together, and being all cold, les them be put into a Glafs Limbeck well ftopt with clay, and the jognts well lined therewith, that there be no expiration; then Jat a little fire be made urderneatb until the Cytron phlegme ceafeth to run, and then let anotber veffel be fet under, and the fire a litele increafed, uncil the drops be firft thick, and then of a Cytron colour; andlafly, drop true oyle of waxe, and let this be received in a proper veflel, mixed with the thicks droppings, and let it be made thick, and like butcer congealed. And now the fire mult be enlarged unit thick drops doe againe dinilt, which as foon as you fie det the veffel that receiverh the. oyle 
oyie bee removed, and another placed to receive the remainder?

Oyle of wax heals the cracks and chaps of the lips or paps, Mizaldusapand binder not the childe from fucking, "and take off all fuper- pendix ad ces" fluous excreicences by drying, and are efpecially good in coid "urias. griefes. It is good for them that are troubled with che fone, provokes urine, helps the Pallie, Sciatica, contracted nerves by anointing or drinking of it; kills worms of all forts, belps the pain of the back, cures a diftempered fpleen, a drop injected into the noltrils opens their obftuction. It conferves the memory, confirms the brain, affwageth the Toothach, brings forth the dead or living childe, opens the veynes, frees the lungs from thick fuperfluities, with firrup of Violets, heips the Aftratick, cures running eyes, \&or:

Wax, faith Galen, after a fort, hold's a middle of things that Gilen l:b. .\% heat, cool, moiften, and dry, and hath fome kinde of shick de fiangl. and ftoppisg parts, and therefore it may feem noc onely to dry, but by accident allo perhaps to moiften, hindring perfpirations; and therefore is the matter both of heating, and alfo cooling medicines, and although forbidden to bee taken inwardly, yec fome make Pills of wax, and others mix it witborher coftives, and give it for a violent loofnefs.

Dioforiaies prefcribes it in broth for ulcers of the bowels, for Diorcorida l. 2: all wax faith hee, mollifies hears, moderately fills the bodies c.75. (which as Dalechampirs expounds, produceth flefh) in hol-Dileshampe low ulcers, and $P$ liny confirms the fame.

New wax, and fof, faith Galew, is better than old, for medicines; yellow wax for the aery riature, doth mollifie, more loofen, and refolve the malady. And therefore new wax is often prefcribed, for being often melted, it lofech she aery nature, is more earchly, and anfwers white wax: And white wax is molt refrigerating, is moft profitable for inflamed rains where the matter is to bee repelled, which yer, faich Aldrovandus, is neglefted by practicioners in Phyfick.

There may bee admirable baths made of hony, which are cxcellent for Aches, and frong Ieches, Mr. Remwaxt faith, that Mr. Rimant. a friend of his had fuch a foul isch, that hee was like a Leper, whom hee thus cared :

L.22. 6.24,

Hec rook an empty Wine cask, called a Pipe, and cook ou 
one head, and made a liquor of water and hony, making it pretty frong with the hony, and heat it as hot as hee could endure to ftand in it, and put it into the Pipe, and caufed him to ftand in it up to his neck a pretty while, and this hee did three dayes one after another, and hee was recovered as slear as ever. The like experience hee made for Aches. If they bee reniewed with a little hony every day it will bee better.

Olao

Magno hift. delle cofe reptenterion, $1,22, c .16$.

Butler Fem。 Mon, part, 2,

Mathissde Lobel.

In the Northern Regions are few Phyfitians, but the healthfull aire, wholefome food, and efpecially their Mead are inftead of the beft phyfick.

Mead, the elder it is, being well boyled, fome fay, ten, or twelve years old, is molt fovereign, and a prefent remedy for many difeafes.

Mead, or Hydromel is of two lorrs, the weaker, and the Aronger, Mead, and Mecheglin.

For the making of Mead, if the Muft, when it is zltogether, bee not Atrong enough to bear an $\mathrm{egg}$, the breadth of two pence above it, then put fo much of your courfe hony into it, as will give it that Atrength, which is fufficient for ordinary Mead. And afterwards untill night, ever now and chen ftir it well about the tub: According to the quanticy that you will make, fo mutt you add a proportionable meafure of hony and water, namely fix of water for one. The learned Phyftian Lobel, requirech this proportion of fix to one to bee boyled to four. His receit of Spices is Cinamion, Ginger, Pepper, Grains, Cloves, ane two drams. The fecond morning put to the Mutt the foum of the hony, ftr all together, and top the tub a lirtle backwird. When it hath fecled an hour or two, draw it out to bee boyled. And when you fee the grounds begin to come, ftay and let the reft (fave the very thick grounds, which caft to your Bees) run into fome veffell by it feif, which $u$ hen it is fertled, pour out into the boyling veffel through the cleath fieve, and calt our thele grounds allo into you garden.

This Mult being fer over a gentle fire, when you fee the fcum gathered thick all over, and the bubbles at the fide, begin

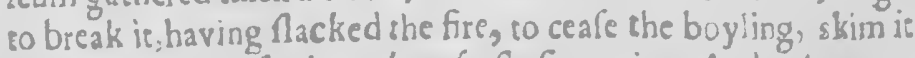
clean. Then prefently make a frefh fire to it: And when you fce the fecond fcum ready, having flacked the fire again, rake it guickly away; then make to it the third firs, and let it boyl to 


\section{Theatre of Political Flying Infects.}

the walting of a fourch part, if it bee made of the walhing of combs; and to the walting of one fifth or fixth part, if is be made of clean hony; nor cealing in the mean fpace to rake off the fcum as clean as you can. One hours boyling may fuffice; but if the Mead bee of clean hony, it may as well bee done in half the eime. Inltead of twice flacking the fire,you may twice cool the boyling Mutt with cold Mut referved; or elfe bee fure that it do boyl all the while onely at one fide, and not all over. After all this put in the Spices, viz, to 2 dozen gallons of the skimmed Muft, Ginger one ounce, Cynamon half an ounce, Cloves, and Mace ana iwo drams, Pepper, and Grains, ana one dram, ail grofs beaten, the one half of each being lowed in a bag, the osher loole, and fo let it boyl a quarter of an hour more.

The end of boyling is throughly to incorpcrate the boorn and the hony, and to purge out the drofs, which being onse done, any longer boyling is unprofitable, as diminithing more the quantity than increating the ftrength and goodnels of the Hydiomel.

As foon as it is boyled enough, take it from the fire, and fet it a cooling; the next day when it is fecled, pour it through a hair fieve, or linnen bag into the cub (referving Atill the Lees for the Bees) and there let it ftand covered three or four dayes till it work, and let it work two daies. Then draw it through the rapwaze, and cun it into a barrel fcalded with Bay-leaves, making the Spice-bag falt at the tap. If there remain much grounds, you may purifie them by boyling and skimming, as before; but this will rever bee fo good as the firt, and therefore you may put it by itfelf, or wich lome remainder of the bet?, into a fmall veffel so fpend firt before ir be foure. If the Mead bee not much, you may cun is the next day, and let it work in the burrel. Being runned it will in time bee covered with a mother; which if by jogging the veffel, or by other means it bee broken, the Mead will turn fowre. But fo will it make excellent vinegar, and the looner, if it beefec in the Sun, which the longer you keep, the better is will bee.

Merbeglin is the more generous or Aronger Hydromel, for it beareth an egg the bieadith of a groat or fixpence, and is sfund'y made of finer hony, witha lefs proporrion ofwater, na nely four meafures 
tox one ; receiving alfo in the compofition as well certain fweet? and wholefome herbs, as allo a larger quantity of Spices, namely :o every half bartel, or fixteen gallons of the skimmed Muft, Eglanine, Marierom, Rofemaiy. Time, Winter-favoury, asca half an ounce; and Ginger wro ounces, Cynamen one cunce, Clores, asd Mace ana half an ounce, Pepper, Graines, ana two drams, the one half of each being bagged, the other boyled Ioofe. So that whereas the oidinary Mead will fcarce laft half a year; good Merheglin the longer it is kept, the more delicate, and wholefome it will bee; and withall the clearer and brighter.

One cxcellent receit, I will here recite, and it is that which our renowned Queen of hapey memory did fo well like, that the would every year have a velfel of it。

Firf, Gather a buthel of Sweet-briar leaves, and a buithel of Time, half a bulhel of Rolemary, and a peck of Bay-leaves; Seethe al thefe, being well wafhed, in a furnace of frir water ; let them boyl the (pace of half an hour, or better; and then poure out all the water and herbs into a Fat, and let it Atand till it bee but milk-warm, than ftrain the water from the herbs, and take'to every f $1 x$ gallons of water, one gallon of the fireft hony, and put it into the boorn, and labour it togecher bals an hour, then 'et it Aand two dayes, ftirring it well iwice or thrice each day. Then take the liquor and boyl it anew; and when it doth feethe, skim it as long as there remaineth zny drofs. When it is clear, put it into the fat, as before, and there let it bee cooled. You muft then have in readinefs a tub of new Ale, or Beer, which ias foon as you have emptied, fuddenly wheim it upfide down, and fer ir up again, and prefently put in the Metheglin, and les it fland three dayes a worting, and then tun it up in barrels, tying at every tap hole by a Pack-thred, a little bag of Cloves and Mace, to the value of an ounce. It mut fland half a year before is bee drunk.

If you marvel that fo great a quantity of water is required, it is partly becaufe of the goodnels of the hony, which being pure and fine, goeth furcher than ordinary; and parely that it may have the longer time in boyling, before it come to iss ftrength, and therefore fome will have eight parts of water to one of hony, but shen they boil is fo much the longer. The third part as leaft being mated.

CHAP 


\section{A Theatre of political Flyinglaneats.}

\section{cHA P. XXVII.}

\section{of divers kinds of wild-Bees.}

Here is one kind not half fo bigge, as a Hony-Bee, with a bright mining green head and fore-part; the hath longet horns than a Hive-bee, the hath four wings, her neather parr is of a light thising Carnation on the out-fide, ebe belly of a greenifh Chining gliftring colour, almoft as bright as the thining of a Glo-worm, with a very large long fting (not forked) or fomewhat like to 2 fting, I could not force is to enter it into my hand, whecher it wil Ating I know not; that which is equivalens to the skin is as it were continued without ringles; this Bee is very Arong, gathers as the Hive-Bee fand aracha; and breeds in holes of old polts, divers near one another, we may call her che gliAring Bee.

There is another fort of Wild-Bee which is very laborious, the is no: fo great as a Hive-Bee by a third part, but in haspe and making alsogether like her, the mouth opens fide-ways, wherewith he holds very faft, like pinchers, her hinder leggs are of a tawny colour, the ringles of her hinder part gray, the relt of a blewilh black, her fore-part is partly black, and partly gray, the ufech to abide (if my memory deceive me not) in Brick -walls, in holes in the morter between the Bricks, many near one another ; we may call her the Mortar-Bee.

There is another fort not half fo great as the former, but grayer, the diggs or mines perpendicularly into Atiffe clay ground in High-ways, or Foot-part fides, the earth that Ge works our, lyes round about her hole like the cafting of a Worme, bue much finer; afrer the hath entred three inches right down, Bee makes traverte holes one under another, fometimes two, fometimes shree in breadih, as feveral cels, or chambers where the breeds her young, which are not Worms at firt, but have a perfed thape of a Bee, herein concurring with the Queen-bee, and though the belaborious, and gachers much Bec-bread, yec could I never finde any thing provided before-hand, or laid up in any cell, bus all is confumed by the young, of which I have found nesr forty belonging to one down-sight hole (nor come to 
marurisy, and maintained by one ; all in feveral cels or partitions one above another, the tranfverfe boles being open to the down-right, that fo they may be vifited and fed by the breeding or Mo:her-Bee, which confirmes my former affertion of the old Bees feeding the young. This fort of Bee is very Politicall, living by hundreds, nay thoufands near one another, but eash in a diftina manfion, we call thein the Earth-Bee.

There is another fcr:abour the length of a Hive-Bee, bus broader and greater made, like a fmall Humble-Bee, but differing in colour, (he hath a round head, broad face, with long horns on the head, a ring of yellow turning upwards, above the mouth the chaps are indented, and hold like Pincers, the back and head are of a dark ruffer, fix dew-clawed feet of a liohe browre, the hath four wings, her neather part is of a dark black, with five yellow ffots on either fide of the edges of every riogle, the hath a broad tayl; this kinde copulates often openly, while the is at work all the Summer; the furres, or darts too and fro as lhe gathers, without a Sing, makes a louder and clearcr found than the Hive-Bee.

There is alfo a lmaller fort of this kind, in rothing differing but in the magnitude, thefe breed in clay-walls of houfes and barns, in holes in the clay which they make many together, like feveral inhabitants to make a TowD, but each hath her peculiar houle, or hole.

These is another fort of wild Bee, altogether as long as a Hornet, but the neather part not above half fo great; it hath eight ringles, the three next the incifion of a fhining black, the four next towards the tayl, which grow all les one then the 0 thes downwards, of a light Orange, and the tayl of a bright brown, the fore-part and wings (which are tut two ) and belly are of an Orange colour, the head not very round, the mouth piked, or like a Birds bill, bue the lower chap longer than the tpper, which opens not fidewaies as other Bees, but one over the other, (wo hort horns on the head, but two wings orange coloured, fomewhat Qhorter than the body, fix dew-clawed feet of an Orange colour likewife, the buzzeth not fo lcud and fmart as the Scarabee, the lives by foot-path fides, and bare places of fields, of a quick figh;, and not eafily taken, withour a thing, copulater frequently, feeds cn Flies and Gralhoppers, 


\section{A Theatre of Politeal Flying Inferts.}

and this obferve as a general rule, that few of thofe forts that have but two wings gather Bee-bread; I might defcribe divers others, but nor being able to recite any particulars of them, I will not trouble the Reader any longes.

\section{CHA P. XYVIII.}

\section{Of the walpe.}

A Walpe is a flying oblong Infect wish four wings, of a A bright Afticolour, the two inmoft neither half fo lorg. gor fo large as the out-molt, fix yellow dew-clawed feet mixed with Chefnue-colour cowards the exrremities, two black moveable horns on the head, growing on either fide as high as the top of the eyes, the head is black and halry, the fore-head divided inro three yellow fpots, with a black ftroke down the middle, the jaws yellow withour, black at the mouth, the jaws hath not the folidity of a bone, but is like a Arong grifle, indented like a Saw, the back is for the moft part of a hining black, and the belly alifo, the neather part is a bright yellow in the fca'es, bur black bars, in the opening of the upper fcale, the black inlargeth it felf towards the middle of the lcale; and laftly, the hath a venemous fpeas wherewith the wil prick often (constary to the Bee ) for it is not barbed.

The Warpes Neft is begun of one, not mary mother Warpes or breeders as fome inagine; the mother Wafpes goe not abroad after they have bied many young, but are maintained by their pofterity at home; whether the old breeders continue tonger than a year A Arifotle queftions, and Scaliger likewile, bui determine not, it being a fecret not then known; but it is appasent they continue no longer, for their wings are worn, and shereby are they difabled for ftighi, much more for breeding.

The mother Wafpes have ftings, and ufe them, and the rea. Arit, de bixtro fon of their abode at home, is not becaule they are great and' anim. lib. 9. heavie bodied (as fome) for their wings are proportionable to c.6 6 ? their bodies, bur: with their much working is the Spring, making cheir Nefts alone, breeding and feecong their young they weas

$$
\text { A } 2=3 \text { theis }
$$


their wings, and therefore afeer a while ftirre not abroad, burt order all at home.

The Wafpes Nelt is made for the molt part in the ground, ( Moule, or Mole, not very deep, about 2 foot and 2 half, fometimes two foot from the entrance, for the manner of their work, malsing of their combes, breeding and feeding, they doe almolt

Sealig. com. ment. in Arifto de hilt. lib. s. c. 19. wholly agree withthe Horner and the Bee, for Bees, Hornets, and Walpes are alike in all, as an Affe, Horfe, and Oxe, and how Hornets breed, See Cap. 10, pag. 43.

The Warpes Neft is made Oval, fome confirt of eight combes or fories one beneath another, fatned Atrongly by many peggs, or pins one to another, abous three quarters of an inch diltance between combe and combe, the middle combes are about nine inches in the Diameter, all round, and the whole involved with a five or fix doubled folding, or watered cover, yet all wrought into one intire peece, confiiting of the fame matter with their combes, being greenith, ruffer, and gray, whereas the combes are of a dark ruffet, with only one hole through the middle of the cover, bigge enough for one Walpe to enter at once; the cover is faltred with fome pins to the ground, or rootes in the earth.

The middle of each combe is fomewhat Piramidall, bending upwards, and hollower in the infide than the outward part of the combe, and the zenter hath a very ftrong pin to faften is to the next combe, which russ like the axeltree or maine polt through them all, and in lefs fpace than every inch in the whole breadch, ase rows of pins, or pillafters, which faften each combe very firmely to the next, fo that they wil nos eafily be feparated. And herein they feeme to have been exemplars of Architelure rather than Bees, falhioning all their combes orderly, Atrongly, ufefully, and comely; the pins or props are framed broader, \& bigger, both at the rop and botrome, than in the middle, with two or three buttereffes both above and below, whereby they hold more firongly, and being fmail in the middle, lefs binder their paffage abour the combes.

The Warpes combis are plaine on the upper part, but filled and furnilhed with hexangle cells downwards, the cells are not fodsep, nor yer fo long as the Bess, and shey are not made 


\section{A Theatre of Political Flying Infects.}

itraight but aftoop, thas the young may not fo readily fall out as they would if they weie directly downwards.

The feed is at firtt almoit as fmall as a Multard-feed, of a darkifh white, not (pherical, but oval, and they faften it not to the bortome of the ce!l (led ad celle lst us aprom more, faith Arifforle) but to a corner or angle, a pretty diftance above the bottome, and Ariff.de hift. Animalol.s. c.ig. obferve (for the molt part) an exact order in difpofing of their feed, that they keep the fame angles in every cell, not one in an angle of the Souch-fide of a cell, and another in an angle of the North, or the Ealt, but all in the South, fo that the feed lyes orderly in rows: But if one layes her feed in the contrary angle (as fumecimes, thoughfeldome) then the next rakes it for a rule, and it is punctually oblerved perbaps through a whote range of cells.

This leed being hatched (for the manner how, fee the tenth Chaper) grows a little while by vertue o: the feminal power, it fticks at one end, bending towards the middle of the cell, but fomewhat erected (or rather dejected, for the head is downward) that it may receive food, and when it fills the breadth of the cell, it grows loole, and falls (or to fpeak properly afcends) to the botiome of the cell, for the mourh of the cell is downwards raifing it felf; and now the mouth of the worm begins to: bee vifible, and it is daily fed, as wee noted of the Eees ( for they are Infeets of the lame nature) but fome what degenerating; and Pliny faith, in feiu,eadem prope natara gire apisus, and grows to the full dimenifon of the cell: when as wee noted in the Hornet, it growo dull and rorpid, and refufing meat is thur up by a cover wrought over the hcad: Bur to recurn back a Inste.

At firt, afres the feed is hatched, it is oval towards the head, near to the tail there is a blackifh fpor; It will contract it felf almolt round, fometimes as a Caterpiller, when it moves, as if it would go, for indeed the worm makes no progreflive motion.

If you break the worm, in the body is a thick waterith humour, with a harder fubftance, like a black hit in the rniddle of it, and thas from end to end.

The tranfmutation begins to bee firt vifible in the fuperiog part, and ches eyes are furt difeerned, aad the incifion between 
the head and the thoulden $;$ which yet as it grows more perfeet; becomes fmaller, the middile incifron is farcely vifible, when the eyes may bee leen, then the legs, and the horns begin to bee framed, and the wings are laft finined. When they are perfeet, they thruft up the covers over their heads which hang at their backs until they come forth.

They excern an excrement while they feed, which is contained under them in the bortome of the cells, but affoon as the young eat their way forth, the older Walpes carry it out of the nealt.

The young Walpes ( though the combes bee taken out of their nealts) that are thut up (not the other, for they mult bee fed, or they will dye inthree or four dayes) will come to life, and perfection, although flowly, becaule of the fmall heat; but for above three weeks I have had them in a chamber fusceffively come to perfection.

They gather no hony, that is, make it, rob they do, but sten

Scaliger com. in Arift. de hiff.l.s c.i 9 . Arift. in los. pred. they fpend it as faft as they get it, yet Scaliger faith mellificant, they begin to breed in the later end of the Spring, contrary to Ariftolle, who faith, they breed not in the Spring, but Autumn, whereas they mifcarry by the end of Aurumn.

They breed firf their own kinde, and by the end of Auguft, ordinarily have fledge Drones, which are about the greatnefs of an old working Wafp, but fome what longer, whole covers they heighten above the combs when they ohut them up, but is cells no greater than the Warpes.

The Drones have no fting, they have rwo tefticles, which on crufhing are eafily difcovered, and they are coatcd with a hatd black runcle, joyned rogether like a pair of breeches, Marper tou ards the poine, but broader upwards, and at the upperend not coated, but full of a whitilh liquor ; the teficles are fomewhat like, but that they are united cogether to the young coated Grafhoppers whilt they are in the dams belly.

The Drones are not of jo bright a yellow as the Walpes, and their moveable horns are a great deal longer, yea longer than the mother Wafps horns, which they [pread very wide like a fork, but not right forth, widening tle.m by degrees, and towards the tops, bending them fide-wayes.

Prefently after they begin to treed Drones, they breed alfo mocher Wafpes, whisbare twice, nay almoft thrice as great as 


\section{' Theatre of Political Flying Injedts.}

the Drones, thefe begin to forfake the neaft about a week in September, and lo daily as they come to perfection, being firt? made prolifical by the Drones with wirom they couple. The Drones continue in the neaft, as long as the working Wafps; namely unsill the wet, and cold in October puis a period to their lives. Whereas the mother Waips, as foon as they have engendered, with the Drones flye forth, and hrowd sherrfelves in hollow trees, thatch,ot luchlike placts, where they lye in a dead fleep without feeding till March, when the firlt warm weather revives them, and caufech them to fye abroad, and then they feed, but if afrer they have been a while abroad, tie Spring bee very cold and wet, they then for the molt part, mif carry, and dy.

For the $m$ sther Walps, they make larger hexangle cells in the loweft combs than for ordinary $\mathrm{Wa}$ afps, and alfo inlarge the coyers above the combs near a quarter of an inch higher than the comb, the covers and highings are very white like fine whise paper.

The young Wa $W$ s are fomewhat gray at firf, and after curo to a brighe yellow, and the Bees are more whice at firf, and after turn to a bright brown.

Ariftolle doubied wherher the Walps loft their Qings in Arit de hilt. Winter; while they are in a deep, or dead Beep, they exercife Animal.I. 9. them nor, tur revive them by a fire, or in your warm hand, and c.6s. you may experimentally affirm the contrary. That they did copulare, Ariftolle; acknowledgeth, but whether the male and female, both had Atings, hee profeffech that hee was ignorant.

Wafpes are a kinde of Canibals, for they rob from all, and eat not the Sees provifion only, but the Bees themielves, aay they will eat the young Walps of anoiher neaft.

Ouce, Walpes are very Atrong, and daring creatures, efpecially near their neaft, noc fearing to anger, nay to injury the molt mighiy. The Poat elegantly thus expreffect it.

A migbty Lion, Lord of all tbe wood,

Having bes hanger ibroughly fasisfid

Spencers vifi-

ons of the

wcrlds vaxity。

Writh prey of beafts, and poyl of living blood

Sufe in bis dreadlels aen bim tbougbt to bide:

B b 


\section{A Theatre of Political Flying Infects.}

$H$ is fermels was bis praile, his frengtb bis pride, And all bis glary in bis crisel claws:

I Jaw a Walp that fiercely bim defide, And bad birs battel aven to bis jaws. Sore bee bim ftung, thes it libeblocd fortis draws s, A d bis prowd beart is filted wir fret fing ire, In vain bee ibreats, bis teetb, bis taily bis palss, And from bis bloody eyes dotb / parkle fire. $T$ bat dead bimfelf bee wifhetb for de fpigbi, So weakeft may annoy ibe moft of might.

\section{CHA P. XXIX. \\ Of the Hurneta.}

A Horner is a flying Infeet, more than ewice as great as a A common Wafp, with four wings, the inmoft fmaller, and not fo long as the utmoft by a third part. For fhape fhee is like a Wafp,but differs in colour: Ail the back wings, and belly, legs, and horns are of a bright Chefnut colour, and fome pare alto below the divifion in the middle, and then yellow fcales, and Chefnis:-coloured openings, or bars with fpots on eicher fide of every yeliow fiale, on the npper-fide but more Chefnutcoloured on the under-fide. Her fore-head is of an iron colour, in the middle of her for-head is a yellow f pot like a heart,on either fide whereof grows her moveable horns, on the our-fide are her eyes oblong, and a little prominent, her face is a yellow fquare like a plate, her cheeks or jaws are yellow withour, and black in the mouth; her jaws are a very bnne indented like a faw, more thick toothed, and finer than a Grahoppers, conerary to Ari-

Ariso de hit, animalo 4. S. E. I. ftosle, and Pliny alfo, who affirm of all Infects, that they have no boninefs in any part, whereas a Horners jaw, and alio 2 great Grahoppere, are a folid bone wirhout, and within of an equal hardnels.

Hornets have nofangs, their tongue is divided into fmall sibers : Their breathing is vifible, cut of one of their heads, and you thall fee (a while) an expulfion out of the neck of a Whicion moifuse, and then drawn in again, at Girf yery Atrongly, 
and then with more weaknels, and at laft ceafiog , yet life continuing in either part of the divided body above an hour.

A Hornets intrals is contracted in the body, but extended, is as long as the bidy, they have a very large cavitie in the end of the tail, out of the middle of it, the fting is extended and drawa in allo as they pleale, it is not holiow (as fome think) that I could difcern;near to the tail I found in diffecting a Hornet (and? never bur once) 2 white egg as great as a lentill, and jult fuch a one as I have feen in the combs, but never diffecting divers Bees, and Walps cou!d I finde any, nor yer in Horoets (excepting one) perhaps they are very (mall (if at all) and quickly grown, and luddenly ejected.

Some fuppofe them to bee bred of a horic: Cardan of dead Cornel. AgripMules: Virgil of Affes: Platarcb of a rotren horfe; and fo allo pal. de occulse fome conceit Walpes are bred, but with us they are bred for the Philofo Rrifto molt part by generation: Of their copulation Ariftotle was de hift. Animal. ignorant, they breed molt commonly in hollow trees, in thatch, or 1 g. c.66. in houfes, in empry Bee. hives, rarely (but fometimes) in the ground: For the manner of their breeding, fee the tenth Chapter, and the former Chapter of Walpes, with whom for the making of their combs, hatching and feeding their young, they do alcogether agree, they are nor fo prolifical as the Wafps, for their combs are never larger, and the cells being much greazer of neceffity, they mult breed fewer : Their ftinging is very dangerous, but orherwife they are not fo mifchievous as the Walps, for though they fometimes kill a Bee, yet they rob not the Hives, they feed on flelh and fruits, and molt of all of athen trees, feeding of the bark, making the boughs whiter and in Auturnn gather plentifully of the? [vy, contrary to Arifolie, and others, who alfert, they gather of no flowers, and herein ro differ both from Bees and Walpes.

They Aling dangeroufly, fome creacures deadly, Dr. Penny repor:s, that being at Peterborong in a publick ftreet of the Ciev Citv, hee law a Hornet purfue a Spartow, whom at lalt Ahee Muffitum ds Aruck with her lting, and therewith prefently killed her, and lnicetsl. s. filled her felf with the dead Sparrows blood, to the aftenifhmentcig. and wonder of many beholders.

It is reported by Aristorle, as a frange and almoft incied.ble thing, of cercain Mice in Per,is, which being diffected, giear $\mathrm{B} \mathrm{b}=$ with 
with young, thore young not yet kindled, have been gra vid, whercas in Hornets and Walps there is a greater mar$v i$, for the breeders coupling in Autumn, continue to bee prolifical in the Spring, and the young bred of them, not onely in the firf, but in the third and fourth generation have a procreative power from the ir great Grand-mothers copulation.

Bil.ce 1.7.

The water of diffilled Hornets, or Wafpes, or wherein they have bien boyled, if it do but couch the skin, the place will fwell fo, that there will bee the fymptories of a drople, or poylon, or fome great diftemper; but Treacle drunk or annointed on the place, is a cure without any pain; with this Harlots and Beggars deceive the molt circumfpect and wary, as if they were with childe.

One thing more which I had almoft forgot: If the hole in the tree wherein they breed bee large, when they bee aumerous, they will work ic up (all but a fmall paffage for entrance) with the fame matter whereof they make their. combs.

\section{HA P. XXX。 \\ of the Hamble-Bee:}

The Humble. Bee is of various magnitudes and coJours, fome greater, but horter than a Hornet; others as little, but rounder and thorier than a Bee. All of them are very bairy, they have two horns, very frong indented juwes, werewith they hold or bite very hard. Some have their heads cole-black, the urper part of the back yellow, che lower part blaok, they have four wings, the belly all black. In the netber. part fitt a divifion or ringle of thining black without hair, then a ringle of pale yellow hairy, then a ringle of black, and fo black to the taile, but thick and full of light gray hairs, that it feemeth gray, thee hath fix legs with fcabrous feet. They carry their BecPlin.Nat. hift: bread on therr legs, as the Hony-Bee, but no wax,as $S$ caliger,

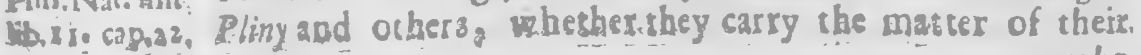
combs. 
combs on their thighs, I am not certain, but beleeve it, for they gather onely on flowers, but the Hornet and Wafpe carry it in their mouth.

They breed faich Ariftotle, on the ground among ftones, Arift:de hit: and have two or three entrances to their neaft, bat it is not Animal.b.g. fo; but they breed either upon the ground, in the long c.67. grafe, moft commonly in Meadow:, and fpsred layes, or elie in a hole in the ground, much deeper than the Walps:- all their neaft is covired; nay environed with mols.

Aris otle and $P$ ing are very brief in the hitory of them, and therefcre very obfcure ; fome imagine the reafon hersof was becaule their nature was well known, but I racher conclude, becaule they knew little, or notbing of them. Scsliger Ccran And it is very evident becaule they confound the Silk- menc in Arift. worm;, and the Humbic-Bees under the name Bombyx, de hift.1.9. and $S$ caliger alfo asic appears knew lictle of them.

The nethermolt ringles of the black Humble. Bee, are as black as jest, clear and thining; nay more traniparent, for it will refic ct an image, but the many long hairs, except it bee nsar at hand, nay in your hand, do lomewhat obfcure it.

Is feems they are very rare, and fcarce known in Iialy, for Aldrovandus glories in a reaft of Humble-Bees that was found by his Apothecary gathering fimple's, and Aldrovand, dz brought to him (as hee faith) not onely to delight him Infectis.l. with a noveliy, but to communicate as a fecret of nature c.q. to polterity.

Hee fuppoleth them a kinde of wilde Bee, and propounds it as a Qrery, whether Fobn Baprist inche wildernefs lived not with their hony ?

Aldrovand fuppoleth wax may bee had out of their combs; but this hee borowed from Ariftolle, who faith, Arift.de hiifo they mak: wax, but paler. than Bees, but melt the combs, if Animal.L.5. you can.

Their combs are oblong cells as bigss Acorns, but wotalicgether folong, cluftering together (one fom:what higher than another, fomewhat like a burch of grapes inverted, fizteen or eighteen joyning together (and then another like comblying clore, but not faltened to it, and 
(o another) of a dark yellow, which (if after they have bred their young ) they fill with Bee-bread, and fome with hony; their hony is of a bright yellow, very fweet, but not fo pleafant as the Beep, having a rank tafte (occafionally) from the ground; their combes are not wax (as before) though gathered of the flowers, they are as rough brown paper, buc not of fo dark a

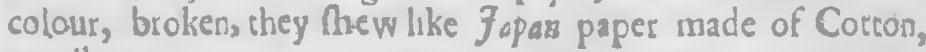
woolley.

They ingender with theirl ayls oppofite one to another, in the meane time refting on fome plant, or the tlump of a tree, they continue long in venery, and while they copulate, often clap their wings, and make a thrill noyfe; their mates they chufe in the Neft, and are carried away by them. Thefe as ort er Infeets before defcribed, after they have done breeding of Females, about the end of Auguft, breed Drones for the propagation of their kind.

It is remarkable, that though the cels or pipes wherein they breed are of a like magritude, yet the Humble-Bees in the fame Neft are of various magnitudes, fome more than twice as great as others, herein differing from Eees and Wafpee, which contioued in the fame dimerfions that they were firft Metamorphofed into, only when they are Itrong and lufty, feeme fomewhat fuller and plumper, but when they grow old, then they grow lank and wither; whereas the Humble-becs, many of them double their firtt magnitude.

They are very laborious and hardy Crearures, working in fuch weacher when the Bees dare nor, and continuirg it mary weeks, after Hornets and Wafpes are laid uf, or mifsarried.

There is another kird of great Humble-Bee, in the fore-part exictly agreeing with the former defcription, but the seather part is altogether of a hining black, ard rot fo hairy $2 s$ the former, it is fharp pointed at the tay $l$, and hath but one cavity, out of the which cometh a fitirg, which growerh out of the under part of the tayl, and is forked like a Snakes tonghue, having two poines forth-righe, not batbed like a Bees, fo that it finges more than once; there are two covers on either fide of the fing to keep it clofe and $f_{2} f e$, and thefe are as long as the fting, but bigger, rougher, and fpreading on the top, I conceive ro hold 


\section{Theatre of Political Flying Infects.}

the fting in, in the at of generation: there are fix particions of ringles on the neither part, and on the outfides, efpecially of the fourrh and fifth golden coloured hairs.

The Humble-Bee firt defcribed, affords fome fpecial rarities not obferved by any, and therefore I muft return to her again. Inthe rayl being ofened, is a double cavity or hole, the one (if I miftake not) for generation and parturition, and the other for the evacustion of excrements, in the neather part (diffecting it) I found as in a Hive Bee, a bladder to which adjoyns the en:ral, not fo whice as in a honie-Bee, then you Anall have (as I have ofien found) their young (bus one vifible at once ) which are not excluded, torpid, and livelefs eggs, buc live and grow in the dammes belly; I have found lome as large as great Tares (1:ke cue Worms in the combcs) fo that all the parts of the Worme are very vifible, and-thefe have lived after I have cut them out fome houres, and would continually contract ard gather themfelves into a round, and then again extend thernfelves, but were not able to make any progreffive motion, being without feet.

In che breaft I perceived a little thing to paot, and beat a gres: while after $I$ fevered it from the lower part at the incifion, when I after, opened the breaft, I found four feveral parts like feveral members, but I was not able (my frght being weaks) to diftine guith one member from another, but concluded there was a heart, liver, and lusgs, ail were reddifh, bur lome parts were more red than others.

Under the horny runicle of the eye is a whice moyfture, and fomething white likewife, like brains in the middle of the head; her tongue is drawn fo clofe, partly under her neek, and partly into her mouth, that it is fcarcely vifible, but when the works; being dead, I found it much lo ger than a Bees, as long as a Barley corn; the hath two fangs, on either fide one, the tongue as the root is as great as a fmall pin, underneath of a black colour to the middle, where it is divided into three parts, two Morier on eisher fide, and a longer in the middle, fo that it hatb a triple tongue; this fort that breed their young within them, are withour a fting; on their bellies near the roois of their leggs, are lirtle round reddion crearures, with yery long horns, with fix leggs, which sun very guick and fwift, which (I bea. lecye.) 
leeve) are a kirde of Lice proper to them; their raile fterched out, is very like their mouth, being as.it were a complement of clawes meeung in a sound, and this is proper to this kirde withour a fting, which I therefore call the Claw-tailed HumbleBee.

Thole which breed a living creature within them, afrer a fort Aritt de ge• produce it egg-fattion, for it is covered with a thin memibrane neranAnimal. like the theli of an egg, but I difeerned no fuch menabrane enl.3.c. $9 .:$ circling the worm in this Humbie- Bee.

This grey Humble-Bee in the tasle is Comewhat broad, and hath two circular horny claw?, or pirce; s not vifibie, till they bee drawn out, and within them two other horter bus not clrcular.

Bodinusthea. Some creatures faith Bodi: us, conceive egos within them, trum nateras and there hatch, and bring forth a living creature as the Viper, 1.3. and all kinde of Whales, bur neither thee, nor any other mentions this Humble-Bee.

Arift.de hift. Whatfoever faich Ariforle, bringech fot th a living creature and l.2.6.60 not firt an egge, hath breafts, and all that have brealts, have paps or nepples except the Dolphin, which hath ewo pipes, on either fide one, which the young ones fuck : The Philolopher, and Scaliger his Commentator, except not the $V$ :per, nor the Slow-worm, becaule they perhaps concluded, inat they hatched the young of analogical egos within the dams belly; I am fure they oughe to have excepted this kinde of Humble Bee as alfo that Fige that wee fpake of before out of Sraliger.

How they order their young after they bee excluded, I cannot yet decermine, for I have not found any of their neafts, fince I obferved this particular.

The Cells or Pipes wherein the young are bied, are not flat at the top as rhe Bees and Wafpes, but oval, and are all of one matcer and colour, whereas the covers of the $W$ alps and Hor nets are, though of the fame fubftance, yes whitex and fioer. 


\section{A Theatre of Political Flying Inferts.}

\section{CHAP. XXXI. \\ Of ibe Grabspper.}

N $N$ the production of no creatures is nature more ferious, $0:$ Irather more wanton than in Grafhoppers, who is able to defo cribe their various coluurs? or the divers forms of their bodies, or can exactly report their walking, leaping, Aying? With us fome are green, fome tawney, fome ruffer, in Elbiopia red and yeliow, is Africa white.

One hath written a Tractace of feven kinde of Losufts or Fran. Stars. Grahoppers according to the Scripturcs, and Rabbins; and yeimenions, nor thofe fonr kindes enumerared among cleas tem gereribus yei mentions, not thole four kindes enumerated among clean locult. creacures, and allowed the fews for food, namely Arbetb a mott prolifical kiade of Grafhopper, which cherefore had this Levit. 1t.2 2 name according to $K i$ inclbi and Broughen. The fecond kinde

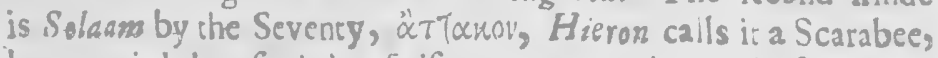
but not rightly, for it is a fwift creature, going on the four forefeet, and leaping with the w wo hindmot which are longer than the orhers. The third fort is Chargol, which in our Bible is tranflated a Beetle, but there is a great difference between Beetles and Grafhoppers, the Greeks, rranlate it oprópaxov, for it fights with a Serpent, and Atrangles it, as both Ariftotle and $\boldsymbol{P l i n y}$ record; and Maiolus in his Colloquies rells us, That his Gardener returning from work, faw one of the fe Grathoppers conflicting with a Serpent, which at latt it killed. And therefore Nipbus was too bold to tranlate it a Scolopendra, or Afpe, when as the Philofopher calls it a Grahopper, and the Seventy tranflate it a Locult. The fourth kinde is called Cbagal,

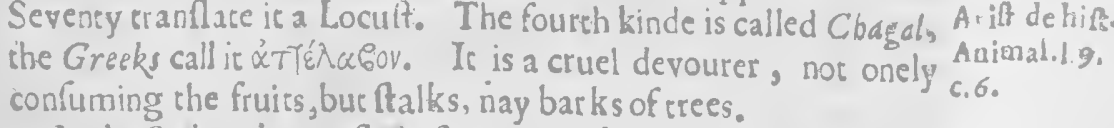

In the Scripture wee finde five other kindes, $G_{a} z_{a}$ from $\mathrm{As}$ ving, Felak from licking, Cbafal from deftroying, Thelatfal from rut, which it occafions to the fruits, and Cberamal from ftay- Rhoduiph ing, becaufe it never willingly forfakes its place. Modins on Modus in Joel, and L:vit. $r$ zckons up various kindes of the firlt fort cal- Ievir. led Arbeli.

Morsoyer in the monch of May, out of a fpittle that hangs C $\mathrm{c}$ 
upon herbs is produced a green winged creature, in Sape very. like the lirtle Graflopper, it leaps, and after Alyes. Wee uie to call the frothy mater wherein ihey are bred Wood-fear, that is the corruprion of the woods; I know not the reafon of the aame; orthers call it Cuckow-ipircle.

In $N_{\text {orrey }}$ ir often raines a lirtle four foored beaft, as great as

Sesliges de Subril,exerci4at. 8.9.

a $R_{a}$, of various coloured hair, which feeds of all green things. like Grafhoppers. When their food fails they dye, and the aire being corrupted with their ftench, caufeth to the inhabitants Megims, and the Kings-evill. They call it Lemmer; this. though not properly-a Grahopper, yet like them very dea. Aructive.

Of what form was the $\mu \varepsilon \lambda$ rgis of Suidas, the wuגaugis of

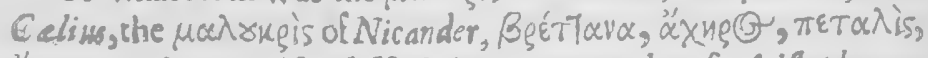

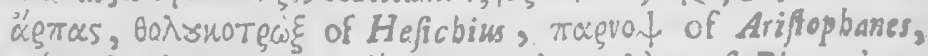

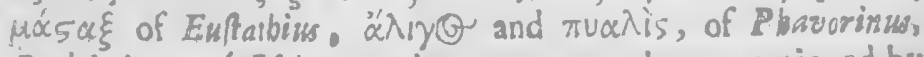
Ludolocbra, of Ifidore, and many many others mentioned by. authors differing one from another, but yet not fully defcribed, much lefs their natures, to that wee need an Oedipus to reveal, and difcover them.

A Grathopper hath two very moveable horr a, as long as the whole body, on either fide ef the jawes two hhort ones; It hath two broad lips Thutting flat on the other, and two leffer that thut lide-wayes, all which together clofe the mouth, and the head, with the lips clofed, fomewhat refembles a horles head. It hath two round prominen? eyes; Nigidius denied that they faw at all, as Pliny record, when as they have clear and glaffie gilin.Nat, birt eyes, yet covered with a horny tunicle (the cyes are not moveable)

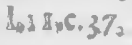
there is a vifible Pupila, fix fect, the hindmott as great, and as long again as the formolt to leap withall, and raife it felf up: with iwo joynts in every one, near their fetting on to she breaft, shefe two are very near one to the other. They have alfo a joynt in the middle, the upper part as the thigh greater at the top, and fmaller downwards, and (moothe. The lower parts (which are their legges) rough and fcabrous, and feveral pliable joynts in the feer, and as it were vifible toes, which are rough and dewaclawed. A long fmooth raile more than half the length of the body, thasp-pointed, and wwo finorz litrle tants, or pricks growa. ing near the end of the tail, pointing towards the exeremity of it. 


\section{$A$ Theatre of rolitical FlyingInfects.}

When you hold it by the wings, shough ir neither firs, nor Atrives, yee thall you both fee and feel the whole body beat and pane, as alfo when it creeps, or ftands fitl, alchough not to much, left of all when it is in motion. It hath four large wings, but the under wings lye folded or doubled, which deceived Willicibits, who unwarily beholding them, took them to bee feveral, and therefore publifhed that they have fix wings; the

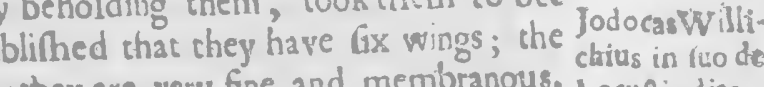
near an inch broad, fpreading like a fail; the upper wings are loga crufty or Ahelly.

It hath as it were, a fcaly Gorget, from the head to the incifion or back. The back is more hard and melly than the belly, and hath feveral femicircular equidiftant frakes down to the belly. The belly is very foft and white on either fide, all along to the tail, and green in the middle.

On the brealt are fharp pricks fix in number according to the legs, againft each leg one. When the head is fevered from the body, the jawer, the lips, the horns, all move, but the head dyes fooner than the reft of the body. The body will leap a great while after the head is off. In the ftomach is a thick juicy moifture. The breaft being opened, firth appears che heart, and then other large members, one like the liver of a reddith coto lour, another lefs and grayer, which I fuppofe to bee the lungss In the belly I have not found fewer than eighty young ones, in fome one hundred. They grow quickly as great as Ant-egas, and as long, they are firtt yellow and fort, full of a yellowiln moilture, then raby, then of a tawny colour, when after a certain fpace this fofter tunicle hardens into a thining black coat, of mell, long and flatcifh, and thefe alterations are all in the fame Grafhopper, for in fome you hall finde all withour coars, in others, fome with coars, and fome with none at the fame time.

They have three black seeth in either jaw, the reecth and jaw are one peece, and of a bony fubftance. In the head is a manifelt brain, or at leaft fomewhat equivaleat.

Sorme Grathoppers have not the long prick at the taile, but two tants above and two thorter underneath, and fone have ftumps inPtead of wings, but howfoever they variounly differ in their extero mals, yet in all that I have diffeoced are alike, the vitals indeed, and

$C \subset s$ other 
o:ner particulars, are not fo vifible in the fmaller, as in the greater.

Grahopoers copulate after the manner of ocher Infects, the Aritt. de hift. lefs afcending the greater; for the male is the leffer. They difAnimal.1.5. clofe their eggs on the earth, faltening a pipe which they have at c, 23,

Br. Valeriola. their tail toir. The males have none : All lay their eggs together in one place, fo that they make a kinde of combe, bus not on the fuperficies of the earth, but a little underneath, then the form of them as they were firt produced, being changed out of that earthy cover,appear litcle and black Grafhoppers,and after the skin being broken on every fide, they become greater, they bring forth their eggs in Autamn, and prefently being delivered of them perith, for there breed certain worms about their necks which ftrangles them faith Pliny, which eat through

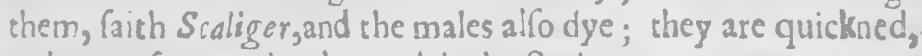
and come from under the earth in the Spring.

Grafhoppers breed not much or mountainous, or fquallid moilt lands, but in Champion grounds which are apt to chap, for they lay their eggs in the chaps and cranies, out of which, Winter being paft, in the beginning of the Summer following, of luch eggs as are alive, come the Locults or Grale hoppers.

They copulate thus, the male afcending the female, puts in tho? ewo cants or pricks that are eminent in the end of the back, by turning back of the tail into the females womb, and they are pery long and clorely joyned together, that they can farce bee fevered, neither yet by leaping or motion, no nor yet without difficulty with your hands.

The female in her venery, moves her belly earnefly, and clofeth in the lower part to the male, and holds him very long, fometimes with the opening of her womb, fometimes with a ftrait fhutring of it, making her dalliance more delighteful; for while her womb opens, the male more deeply infinuates himfelf to the bostome of it, and when it is contracted, is more delighted with the pleafure of it.

There are feen $t w o$ paffages in the females privity fevered each from other, and covered with a thick coat $g$ it is black $Q \theta$ the out.fide, and hard and cartilaginous, but within feems. ccrmewhat roygh and fabrous, with certain wrinkles at the bot:- 


\section{'A Theatre of Political Flying Infects}

bottome of this covering, the womb growing white, is like a womans privy parts. The male after copulation dyes; For by a long concirued ule of venery, they fpend all their radical moyfture and fpiries allo. The females after they have broughe forth either by the violence of the pain, or multitude of their young, whereby their Atrength is confumed, perifh likewife; or as Ariftorle by litele Lice which oreed in their necks, and as $P$ liny fasth, Atrangle them, as Scaliger, eat into them and kilk them.

They flye over large Seas, conenuing divers dayes together in their flight, and make fuch a noife with their wings, thar they feem to bee Fowls, and thadow the veiy. Sun.

They infeft Ilaly oftentimes ous of Africe, confuning a!! with their bitings, and with their black, Aharp, and burning excremenes, and with a fharp flaver, which they in earing let fall out of their mouths, yet are chey not poylon, for both the Partbians and Etbiopians feed of them.

Willicbius affigns them a King, and a Monarchy, but Solsmon denies it, laying, That tbey bave no King, yet go they fortb all by Pro bands, but though they bee frine rege of lege, yet have they a confpiring agreement to do mifchief.

- When they wafted Gaul 852. they marched in the aire twenty miles a day in an ordered battel, and formed fquadrons, and when they fell on the earth they had their camp; the Commanders with a few wene before the Army a dayes jounn, as is were to finde out fit places to quarter in, and the very fame hour that the fore-runners or harbingers came the day before, the whole Troups came the day afeer; before the rifing of the Sun they furred not from the place where they lettled, but the Sun being rifen, they marched, or flew away in their orderly Regiments.

Cufpinian obferves the lame, in the fame Counery, in the year 874. but with this difference, that they maiched then but four or Culpinizsois: five miles a day.

Of Locults there are fometimes feen fuch monttrous fwarms I. Leo hift, of in Afraca, that in fying they intercept the Sun beans like a Atrica lig. shick cloud. They dovoure trees, leaves, fruts, and all green things growing out of the earth.

As their departure they leave eggs bebinde them, whereof. C $\subseteq 3$. othes 
other young Locufts are bred, which in the places where they are left, will eat, and confume ail things, even to the very bark of rees.

Sealiger exer. Their coming is knowo by the difcolouring of the fields long citat,192. before, for they fhine by reflexion?

Julius Obse- Before the birch of Chrift, about a 170 . years, the Paftures qqueng. of Italy, were covered as it were with clouds of Grahoppers, and about Capesa a hundred years together.

In the Confullhip of Marcus Plant ias Hypfaus, and Marcus Paulus Orofrus Eulvims Flaccus, Africa farce breathing from bloody
sontra paga. aosib sic.11. whereas now throughout all Africa, infinite multitudes of Lo. cufts were gathered together, and had not onely quite devoured the corn on the ground, and confumed the herbs with part of their roots, and the leaves, and cender boughs of the trees, but had gnawn allothe bitter bark, and dry wood, being with a violent and fudden winde hoifted aloft in mighty fwarms, and carried along time in the aire, they were at lengeth drowned in the Africon Ocean. Whofe loathfome and putrified carkaffes being by the waves of the Sea caft up in huge heaps far and wide along the thore, bred an ineredible finking and infectious fmell: whereupon followed fo general a peftilence of all living crearures that the corrupt bodies of fowls, cattel, and wilde bealts diffolved by the contagion of the aire, augmented the fury of the plague. But how great and extraordinary a death of men there was, I cannot but tremble to report: For in Numidia where Aliciffa was then King, dyed fourfcore thoufand perfons (in the Kingdom of Malfiniffa according to Eutropiu, if I miltake not, eight hundred thoufand.) And upon the Sea-coaft next adjoyning to Cerrbage and vitce, above two hundred thoufand are caid to have perifhed. Yea in the City of $V_{\text {tica }}$ it felf were by this means fwept from the face of the earth thirty thoufand brave fouldiers, which were appointed to bee the Garvifonfor all Africa. And the deftruction was fo fudden and violent, that ourt of one gate of Vicica, in one and the fame day, were carried above fiftecen bundred dead corpf $s$, of thofe lufty young gallants. Georgius $\mathrm{Ce}_{-}$In the Reign of Bafilius the Emperor, the Eaftern parts were Compend. confumed by Grathoppers, that the inhabitants were forced 


\section{A Thbatre of Political Flying Infecis.}

so lell their children, and at laft to pafs into Tbracs. But afterwards a venement winde carried them into the He le (por:, where they were drowned and caft up on the rands which they covered, and prodigioufly lived again of themlelves, and wafted all the Counrries adjoyning, and Tbrace, eipecially thrce years togerher.

In May 3550. an innumerable multitudé of Grahop. Fastlus ds pers of an unwonced greatnels, and uncertain original, appeared rebus.ficulis. in the Province of Catans in Sicilia, which coniumed Corn, Vineyards, Woods, Gardens, and Trees, both domeftick and wilde, and confumed their barks to the very roots every where in one day, and then by a fudden wind were carried into the Fonian Sea, and there drowned; but being after calt upon the Sicilian thore, cauled by their ftink a cruell plague in 7 uly following.

Swarms of Grafhoppers came out of Africa into Iialy, and allo into France 1353 . and alfo I 374. caufing fuch a famine and placue, that the third part of the people perifhed, and they Otho Fririnhad molt of them fix wings, and at laft were hurried witb a genfus. violent winde into the Britcifh Ocean.

About Mifnia, 543 : there were fo many Graftoppers Jacobus Ekthat they covered the ground about a cubit thick. celiug.

In. all the Dominions of Prete Jaxni is a very gtreat and Fran Aluartza horrible Plague, which is an innumerable company of Locufts, Echiop. Hiftod which eare and confurie all the Corn and Trees, and the num- cap. 32. ata3; ber of thefe Creatures is to great, as it is incredible, and with their mulcitude the r cover the earth, and fill the air in fuch wife that it is a hard matter to be able to fee the Sun; and if the damage which they doe were general through all the Provinces

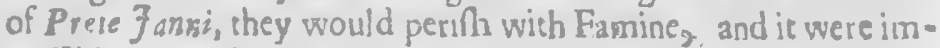
potible to inhabite rte fame, but one year they deftroy one Province; fometimes in $\mathrm{two}$ or three of thefe Provinces, and wherefoever they go, the Country remaineth more ruinate and deftroyed, than if it had been fet on fire.

Thefe Vermine are as great as a great Grahopper, and have yellow wings, we know of their coming a day before, nor becaufe we fee them, bat we know it by the Sun, which hew. eth his beams of a yellow colour, which is a figne that they draw near the Country, and the ground becoming yellow, through 
through the light which reverberateth from their wings, whereapon the people become fuddenly as dead $m e n$, laying, we are undone, for the Locults come.

During our abode in the Towne of Barua, we faw the figne of the Sun, and the fhadow of the earth, which was all yellow, wherear the feople wete half dead for forrow; the nexr day, the number of thele Vermine which came was increcible, covering four and twenty miles in compals.

At another time we travelled five daies journey, through places wholly walt and deftroyed, wherein Millet had been lowne, which had Atalks as great as thole which we fer in our Vineyards, and we faw them all broken and beaten down, as if a Tempelt had been there, and this the Locults dd; the trces were without leaves, and the barks of them nc:e all devoured, and no grals was there to bee feen, for they had eaten up all things, and if we had not carried Viauals with us, we and out cattel had perilhed.

This Country was all covered with Iccufts withour wings, and they told us, hat c hole were the feed of thi $m$ which had eaten up all, and that as foon as their wirgs were gr Wne, the y would Seek after the old ones, and the number of them was infinite.

While we abode in a place calied Aquate, at another time came fuch an infinire fwaime of Lccults, as it is irced ble to declare, they began to come about three of the clock in the afterDOOn, and ceafed not cill night, and as they came they lighted, and the next day in the morning they began to depart, fo that by nine of the clock shere was not one of them left, and the trees remained without leaver.

The fame day and hour there came another fquadron of them, and thefe left neither bough nor tree unpilled, and fo they continued for the ípace of five daies, and they faid they were young ones which went to feek the old ones, and they did the like, where wee faw them that were without wings, and the compais which thefe Locults rook, was nine miles, wherein was neither leaves, nor barks on the trees.

This Country feemed not to bee burnt up, but ra her to bee covered with fnow, by realon of the whitenels of the trees, which were all pilled, fo that all the Country remained bare.

At fuch times the prople depart from their own Country, fo that 
that wee have found all the wayes full of men and women, travelling on foot with thesr children in their arms, and upon their heads, going into other Countries, where they might finde food, which was a pitiful thing ro behold.

Ouce, Eutropius makes mention of grear Locults, which Eutropius 1. 4: were feen not far from the Roman Territory, fo formidable, and fuch devourers, that the inhabuants were frighted with the beholding of them, fo that wee muft conclude that theie fmall creatures have a chief place among Gods Troops and Armies. If Pbaraobask, Wbo is the Lord? Not Angels, not Men, nor yet fierce Lions, and Tygers, but devouring Grahoppers laall bee his challengers and conquerors, and $2 s k, W b_{0}$ is Pbaroob?

They are all females if wee beleeve Vincentius, and Abersy. Vircontiuss as the Scarabees all males. Great droughts produse them; at leat caule a prodigious increale of them, 1553. after five years drought, were great Armies of them ; And Paniw Dracowus reports that in the tenth year of Mauritius the Emperour after a great drought from January to September, there were infinice multitudes of Locufts, which two years caufed a great famine in Italy, by tonfuming corn and fruits, and 1 542. an innumerable multitude of Locults over- fpread a great part of Exrope, at firt they wanted wings (being it leems produced by the drought) after they had two, and then four, and having watted one place, went unto another, leaving a terrible ftink after them wherefoever they had been, but at laft with Autumns cold Cornelius were deltroyed.

Their extraordinary appearance is (accounted by fome) a fign of an approaching plague, fometimes of war, for ic is re-curillis. ported, that two Armies palting by Clermont into the Roma-Genrgius Tis naick Territory (a place in France) there foughe cogecher, where ronenfix. many of of them were killed; when Clorarius was abour to fight with his Con Cbrannus, whom overcoming, hee caufed to be burnt with his wife and children.

Thefe eaters are ufually eacen by the inhabitants of Arabia deferta, and of Lybia, who efteem their coming as a fortunate Jo. Leo litij: boading, for feething and drying them in the sun, they bruife them to powder, and fo eat them.

And they were the food of Jobs Baptift in the Defart, yet chere have been fome, as T beophy lalt reftifies, who undeiftood 
Throptilzes, by xufiolas, the budi or tops of certain herbs, or fome kinde of wilde fruits, in which number was Hermolaus Barbarus, who faich Cbryfopome, and Asbanafrus before him, were of the fame judgement; but $\boldsymbol{C}$ \} foftome denies.jt, and faith a Locult is a Marce is Imall cieature, betwen a flying, and a creeping; of which in the Defarts of 7 rdes were great Alore, they were wont to boyle them in oyle, and they were the food of the poorer fort.

Augurt in Augufine confirms is alio, that $q$ obn fed of Locutts. And Epie, ad Rom T teoppilad witneffech the fame: who doch alfo interpret the eating of Locufts allegorically, as allo Orisien.

Adamani. Diodorus faich that the Acridofagi, or the Etbiopians borOrigines, dering on the Defart that feed on Giafhoppers, are of lowe: Dlodorus, farure than orher men, lean, ard exceeding black; So alfo Siculuslib. j. Strato, and adds they are of a very thors life, feldome exceed.

Serabo. Geoprax.l.16. Soliaus p $\approx$ ! hilt.c.43. ing forty.

And Solinus alfo rakes notice that the borderers on (Asurtranio in a certain leafon (the Spring) gather great quancities of Locults which they falt, and live hereof all the year, but none out-live forty years.

The Parthians of old fed of them, as. Pliny reports. And Scaliger exer. Scaliger laith, the Sirians and Perfisos eat them before they

Mieron. Mercurialis lib.2. rarolect 20 . have wings, ilamely the young ones.

le is to bee obferved, shar all Grathopperacaters are of a Thort life: A learued Phy fitan enquiring what was the caufe. the people about the Red-fea are troubled with boyls en their leos and armes, derrands if it bee from the aire, or the region, or theirfood, concludes peremprorily is was from their food. And Diodicrus. Digdorss affims chas eertain people with frequent eating of 1.3. cap, 3. Anathasias. Iocufs, wer: not onely thort lived, but much anguifhed, and at laft confumed, not onely with boyls (mentioned before) but with a irnei kinde of winged lice, of which one gives a full relation. At the Viral iquinsx when the South-weft-winds blow from. an urcertain piace, an ircredible number of great Locufs are brought, which in flying differ litele from birds, bur much in the thape of cheir bodies. Wirt thefe Locufts falced and otherwayes prepared, the people live, they are excellent for footmanfhip, buifeed ng of fo diy nourifhment, they live not beyoud the forcieth year, for then they dye, if no: befores a milerable dearh, for a cerain kinde of winged lice is bredin their bodies, like unto Dog: 


\section{I Ibeatre of Political Flying Inferts:}

Bog-flyes, but fome whatlefs. They begin at the breaft and belly, and in a thort fpace eat off all the skin of the face. Some of them are like Lepers, and gievourny fcratch themfelves, and the difeafe Aill continuing, and thefe vermine increafing, their humors are fpent, and they extreamly tormented, till at leng:t they bee killed and confumed by them.

\section{CHA P. XXXII. \\ of American Bees.}

N the Welt-Indies the Bees are fmall,about the bignefs of Guncalo "Fer" Flies, or fomewhat greater, and the points of their wings cut nandes de overthwart, and have through the middie of the wing, one white Oviedo natu:

line acrofs, They have no ting.
They make great Hony-combs, and the holes in them are Indias.65\%. four times greaser than the cells of our Emropiean Bees, although they bee much fmaller, their hony is good and wholefome, but it is very dark, like wine being boyled.

In the Ifland of Cuzurnel, which is near the coaft of 7 ucatar, R.hamusco there are many Hives of Bees like thofe of Spain, but lefs, and vol.terzo defle much hony, and wax, the hony is like the Spanifo hony, but Indie 1.17.c.5. fomewhat harper.

In the IQland of Hifpaniola are no Bees, that ever I faw or heard of. In the firm land are very many, and of many kindes, Goncalo Fern: as well as in the form and thape of the creature, as allo in the va- da generale \&e riety of the tafte and colour of the hony, and difference of the narurale biftowax. ria della India

But though Oviedo neither faw nor heard of any,yet are there l.is e.3. apud

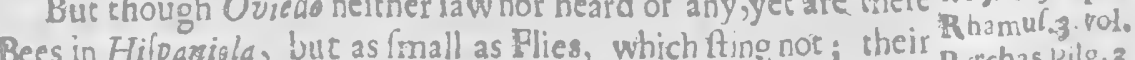
Bees in Hifpaniola, Uut as mall as Plies, which It in not; their P.rchas pilg. 3 hives are four times as great as ours, their hony is white.

part l.5 c.3.

In the Indies are feiw fwarms of Bees (hee underttands do. Jo.Acefl.l. so meftick Bees, which then were rare, but now in many placesc.34 common。

Their Hony-combes are found in srees, or under the ground, and not in Hives as in Caffile. The Hony-combes, which 1 have feen in the Province of Charcas, which thicy call Cbiguanas are of agray colour, and have little jurce, and are more like unto 
Iweet ftraw, then to Hony-combes. The Bees are little like, uñ to Figes, the hony is Tharp and black, yet in fome places there is better, and the combs betterfalhioned, as in the Province of Tueuman in Cbille, and in Carebagene.

Cronica del

In Pern, efpecially about the City Cartago, are many Bees; Peru perPedro which breed in hollow Trees, and make as good Hony as the de Cieca, c.25 Bees in Spaine; there is one fort of Bees not mush greater than Gnats, thefe ftop up the hole, or paffage into the ravity of the tree, and by a pipe of waxe as great as the middle finger, goe in and out to their labours, their Hony is thin and fomewhat harp, they get ufually abour a quart of hony out of a tree.

There is ano: her fort of Bees which are fomewhat greater, and black (for the former are white) the entrance into the tree where they work is made up (except a paffage for them) with waxe, and fome other mixture, whereby it is harder than a ftone, their hony is without comparifon better than the former, and a Tree will afford ufually a gallon, and fometimes. more.

There is another fort of Bees which are greater than the Spesifp Bees, but none of them fting, but when they finde that any coe about to plunder them, they will charge upon him that cuts the tree, and hang about his hair and beard; thefe greater Bees yeeld ufually three gallons out of a tree, and it is farre betrer hony than any of the former.

An: D'Her- . In the Province of Grayaquil, which is not farre from Quito, rera Hittoria general de los hichos, \&ec decad. 5. lib. 30, c. 10,

Maximil.

Tranfilvanus in Epilt. ad Epifcopo falis. burg. they breed in Trees, and are not much greater than Flies, the Waxe and the Hony which they gather is red, and although it hach a goodrafte, yet is it nor like to the Hony of Caftils.

Near the Rivers of $V$ affes and Plate, the Bees are not like ours, beir.g not greater than the limall Flies wherewith wee are. troubied 11 Summer; they work in Trees, and make larger combes than ours, the extremities of their wings are blunt,'as if they were cur( (Ovie do and $T$ beret confirm it) or bitten off, and have in the midsle of ehem a crofs fpo: drawing towards white, without ftings, heir wax is as black as pitch. The hony generaily of the Bees, of the new world, candies nor, bur is alwayes liquid like oy!

Huldrichus The Country of Mackafies 372. Germane miles from the smidel. City of Afumpion in the River of Plase (nearPerus) is fo abundant 


\section{A Theatre of Political Flying Infects.}

abundant in Bees, that you Thall fcarce open any tree with a hatchet, where will not run out five or fix meafures of pure hony; the Bees that make it are very lietle, and w: thour itings.

Aldrovandas citing Hifpanus faich, that in the Inte of Cy- Pet:us Hilpa. mana, the frarms hang on the Trees, and fijow down with nus. hony.

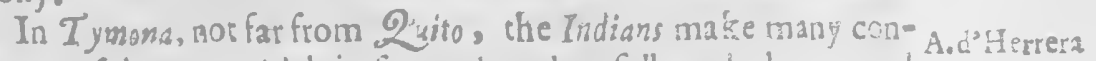
ferves of hony, which is fomewhat plentfull with them, and de las Indias fend them to fell to the Countries round about them, occid decad Go

The Indians of $C_{\text {umana }}$, alchough their Country bee weil i. 3..c. 16 . replenihed, with good bread, corn, fruits, and all kinde of Gifh Linicoten, l.3. in great abundance, yet eat Bees, Lice, S piders, \&c.

The Brafilian Bees are very unlike ro ours, and differ not Hir.Navigat. much from the litele black Aehh Flye; which annoy us in Sum- in Brafil. Lesio mer, and make their combs ufually in hollow trees; they call us. the hony $\gamma_{r a} a_{2}$ which they eat as wee do, their wax is as black as pirch, which they call $r_{\text {etic }}$, they ufe it not for candies, as wee do, but co ltop their great $\boldsymbol{C}_{\text {anes, }}$ wherein they keep their fezthers that they bic not eaten by a kinde of Butrer-flye, which thiy ca!l Araveis. They come in multitudes to the fire', like Crickets, where they eat whatfoever they finde, efpecially they gavaw the upper pars of ieachern doublets, and hooes. If wee negilgently relerved hens, or other food, in the morning, wee Thould have onely bones,

Several forts of Bees in Brafile: Yeacee is the fmalleft of Mr.Toh.Staneer: all the Bees that ever I have feen in the Country, and is in ma- my friend, and king much like a gnat, but of a yellowifh colour, and hash coms neighbour who monly her hony in the hollow of a tree, either at the roor, or not abo ve three or four foot from it; it fingech not, and where years in Bra 6$\}_{\text {i. }}$ they enter, they make a pipe of yellowih wax about four inches long, with the mouth of it, like to the mouth of a Trumpet, the combs are joyned together like clutters of Nurs, and their bony is an excellent ballome, for $\mathrm{I}$ have had experience of it my felf for the curing of very dangerous green wounds.

Zellab, and Zellobfon are the two chief forts of Bees, and fting not at all; ; the leffer is fo like our Bees here in England, that I think I hould nor know one from the ocher, the other is bigger, bus yer much of the fame colour; they have honey in abundance, and the further upinto the Countey the more plenty; I have 


\section{'A Thearre of Political Flying In/ects:}

feen more taken out of a tree at a time than a Firkin will hold; as elear as ruaning water, but if drunken, it is exceeding Atrong, and caufech thire, it mult bee saken very moderacely. They build moft commonly in fome lol:ow bough of the tree, or elfe in the body of a tree, called by the Inaians Kerawvab, they have their hony in clufters of balls, much like our HumbleBees, and cheir young ones in combes which lve compalfed with the balls of hory, and in the balls you thall find fome hony as it is new brought in, very thick and dry, but tafte it, it is very foure, and fo fome more near ripe, but not fit to eat, untill it come to be clearas water; you may fee in the balls or clufters, the colour of the bloffome from wherice it was gathered.

There are two orther forts of Bees that are but fmall, and of a black colour, one fort Atingeth not, but the other doch; they are very like each to other, and build abour the midd!e of the tree, the hony of them both is much alike, but nor fo good as the former, being of a darker colcur, and their combes are is manoer with the former, and they are called Erete.

There are orher forts of black Bees called Ereprob and Erepnoba Jor, they borh fting, and intangle much in a mane hair, the one buildech in the hollow of a tree, and the other in the branches, that which buildeth in the hollow of a tree, will nor fuffer any man to come within two or thice rods of the tree where they are.

I never faw any of their hony, bur the natives have cold me; that they have indifferent fore, but it is very laxative, and breedech difeales in the eater, as bloody fixes, orc. the other buildeth in the bianches, and make their houle of dirt, bigger than cre of cur large Bee-hives, and enter at the middle of it, the ir yourg, are as it were, in little cells or chambers, and from thence betweenfeveral layings of dirt, they bave their hony, which is not very much, but is binding.

There is anocher fmall fort of Bees, and they either build in ficlds, where there are bu: fmall fore of trees, and they low ores; they are of an any colour, and build in the branches like Ereprobs but their neft is like a fila, or skin, and of the colour of the Bee, they have not much hony, and have a thin flat combe, or elie tbey build among the Tobacoes, and from thence they take sheir name, being called I Gbarave. 


\section{A Theatre of Political Flying Infects.}

In Hifpaniola their Walps are greacer than ours, and fing more dangeroully. There are many of ehem, and they very poy- Puschas Rilg. fonfull, they caufe great pain when they fting, they are like thole of Oviedo 1. is. Caflite, but fomewhat greater, and under their wings above the c.3. yellow towards the end, have a litcle Lion-like colour. More oviedo.Suma: fully in another place, hee faith, There are many Walps in the rio dela na. Welt-Indies. They are very hurtfull and venemous, and their tural y geneo ftinging is without comparton, more painfull than the ftinging ral iftoria de of Spanifh Wafps, they are almolt of the lame colour, bue grea - las Indias c.49s. ter, and the yellow of them is more red, and their wings are fported with a black colout, and the points of them seddith of a burnt colour:

They make very great nefts, and the clufters of their combs. are as large as the combs that the Bees make in Sfain, but they. are dry and white inclining to ruffet, they have nothing in thent but their young: They breed in trees, and alfo in the roofs and timbers of houles a

There are many Hornets in Hifpaniola, and their Atinging more torments, than the ftinging of their Walps.

There are two forts of idomets in Brafile, which the Indians call Moribardas, ste one black, and the other much of the colour of them wee have here in England, but the black is Rhamufio lis: bigger and longer, and ftingeth violently. They make their houle like a Canopy, or mucb like to the top of a Bee-bive, and they are faftened to a bough of a very high tree; fo that they feldome offend any man, unlefs they fitt offend them; bur your herdimen arefomecimes much vexed with them, in driving their cattel, they are uaruly many times ; they run among fome Sippoes or Withes that run into the tree, whereby they difturb: them, and then they come down to the terror of men and beafts. Their houfe is open below, fo that you may frand uno der them, and fee them go inco a comb that lyect flar an the: bostome, much like to our Hony. comb. 


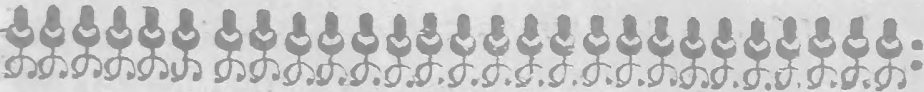

\section{Books lately Printed for Thomas Parkhurft,}

at the Sign of the Three Crowns, over againat the Great Conduit, at the lower end of Cheapfide.

A Learned Commentary, or Expofition upon the firt A Chapter of the fecond Epitte to the Corinsbians, by $D$. Ricbard Sibbs, publifhed for publick good by $\tau$ bomas Manton, Folio.

There is newly come forth Mr.William F erner his Continuation of Chrifts Alarm to Drowfre Saints, with a Treatife of Effeetual Calling : The Killing Power of the Law : The Spiritual Watch : New Birth: A Chriftians ingtafting inco Chrilt: A Treatife on the Sabbath, which were never before princed, bound in one Volume, Fol. and may bee had alone of them that have his onter Works, as well as bound with all bis former Works, which are now newly Printed in the fame Volume with this.

Truch brought to light, and difcovered by time, or an Hiftorical Narration of the firt fourteen years of King fawes, in $4^{\circ}$.

The Journal or Diary of a thankful Chrittian, wherein is contained Directions, for the right method of keeping and ufing, according to the Rules of Practife; 2 Day-book of National and publick, perfonal and private paffages of Gods Providence, to help Chriftians to thankfulnets, and experience. By Fohn

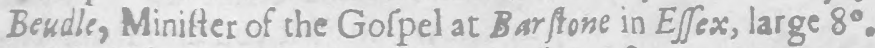

Mr. Robinfons Chriftians Armor in large $8^{\circ}$.

Book of Emblems, with Latine and Englifh verfes made upon (Ligbis) by Robert Farly, fmall $8^{\circ}$.

Grace to the Humble, as preparation to the Sacrament in five Sermons by Dr. John Preftor.

Pidure Louventes, or Pietures drawn forch into Charafters, $12^{\circ}$.

A moft Excellent Treatife containing the way to feek Hea- 
Vens Glory; to flye Earths vanity; so fear Helis hortor, wik godly Prayers, and the Bell-mans fummons, $12^{\circ}$.

Fobrooss Eflayes exprefled in fiandry Exquifie Fancies.

The one thing neceffary; By Mr, Tbomas Wat on, Minifter of Stepbens Walbrook, $8^{\circ}$.

Sion in the Houle of Mourning, beenure of $\mathrm{Sin}$ and Suffering, being an Expofition on the fifth Chapeer of the Lamenratioms, by D.S. Paftor of Upinghans, in the County of Rut=band.

Groans of the Spirit, or the Trial of the Truth of Prayer.

A Handkercher for Parents Wet-eyes, upon the death of their children or friends.

The Dead Saine fpeaking to Saines and Sinners living, in feveral Treacifes, viz. On 2 Sum.24. 10. On Cant.4.9 On 7obn -15.. On Jobn 1.50. On I/58.2. On Exo. 15.11. iNever publifhed before. By Samuet Bolton, D.D. la.e M. Qter of Chrifts Colledge in Cambridge.

Four profirable Treatifes very urefull for Chriftian practice, viz. The Killing Power of the Law: The Spiritual Watch : The New Birch: Of the Sabbath. By the Reverend Williar Eenner, lace Minitter of Rucbfora' in Effex.

Peoples Need of a Living Paftor, at the Funeral of Mto Jobin Frosi, $M_{0} A$, by $M r . Z$ acb. Crofron.

A Treatife againft the Toleration of all Religions. By Mr.Tbomas Edwards.

Chatechizing Gods Oidinance in fundry Sermons, by $\mathrm{Mr}_{\mathrm{r}}$. Zanisary Crefton, Minitter of Buttolpos Aldgate Londion, the fecond Edition correced and augmeneed.

A Coppy-Book mechodized and ingraven, by $T$ bomiss Croffe, wherein fair Writing is expreft, by which one may learn so wrize of himfelf, that can but reads

Dr. Stougbtons thireen Sermons containing the form of Sound words, and fome other Treatifer.

The Godly Mans Atk, or City of Refuge, in the day of his Diftreis, diffovered in divers Sermons, the firt of which was preached at the Funeral of Mrs. Elix aberb Moore. Whereunto is annexed Mrs. Elissaberb Marves Evidences for Heawen, compoledand collested by her in the timeof herihealcb, 
for her comfort in the time of ficknefs; By Ed.Calamy; B. D\} and $\mathrm{Paftor}$ of the Church at Aldermanbury.

Encbiridien $\mathrm{Judicum}$ or $\mathrm{Z}_{\text {eho }}$ apbats Charge to his Judges? apened in a Sermon before the Right Honourable the Judges; and the Righ, Worthipful, the Sheriffe of the Couney Palatine of $L_{\text {ancafier. }}$

Together with Cataftropbe Magnatum; or King $D_{a}$ vids Lay mentation, at Prince Asners Incineration. In a Sermon medita: ted on the Fall, and preached at the Funeral of the Right WorThipfal Fobn Aiberton of Aiberton, Elq; High-Sheriffe of the County Palaxine of $\mathbf{L}_{\text {ancafer. By }}$ Jobs Livejey Minifter of the Gorpel at Aiberton.

-There are going to the Prefs fome new Peeces of Mrowilliam Fenkers, late of Rotcbford in Efex, never yet printed, preferved by a Ipecial Providence, one of which is a Second Part of his Wilful Impenitency; being five Sermons more that he preached upon the I8. of Ezekiel, and the 320. Verfe, 